ROGER BIGANZOLLI FERREIRA

Contribuição para a avaliação da infraestrutura cicloviária do município de São Paulo por meio de parâmetros geométricos e de qualidade de pavimentos 


\section{Contribuição para a avaliação da infraestrutura cicloviária do município de São Paulo por meio de parâmetros geométricos e de qualidade de pavimentos}

Dissertação apresentada ao Programa de PósGraduação em Engenharia de Transportes da Escola Politécnica da Universidade de São Paulo, como parte dos requisitos para obtenção do Título de Mestre em Ciências

Área de Concentração: Engenharia de Transportes - Informações Espaciais

Orientador: Prof. Dr. José Tadeu Balbo 


\section{AGRADECIMENTOS}

Ao Samuel, por toda parceria, companheirismo, paciência e amor.

A meu pai, minha mãe, minhas irmãs e, principalmente, minha avó Maria, que nos deixou cedo demais. Agradeço fortemente por estarem ao meu lado e por nunca duvidarem do quão longe eu poderia chegar. Obrigado por darem sentido e forças para seguir meu caminho adiante. Sem vocês, este trabalho e todas as conquistas que já obtive não seriam possíveis.

Ao meu orientador Professor José Tadeu Balbo, por ter acreditado em mim e neste projeto desde o início. Sou fortemente grato por ter me mostrado que, com dedicação e força, os desafios são possíveis de serem superados. À Professora Mariana Gianotti, que também nos acompanhou nessa trajetória. Muito obrigado pelos direcionamentos iniciais, pelo apoio e confiança em meu trabalho.

À Fernanda Bardelli, pela contribuição nos levantamentos de campo e dar suporte a este projeto. Mais que uma amiga, você é uma inspiração diária que me fez acreditar no imenso potencial de transformação que a bicicleta tem sobre as pessoas e o mundo.

A meus amigos, colegas de trabalho, de profissão e todos aqueles que, com um sorriso no rosto, me disseram que este trabalho seria possível. 
Autorizo a reprodução e divulgação total ou parcial deste trabalho, por qualquer meio convencional ou eletrônico, para fins de estudo e pesquisa, desde que citada a fonte.

Este exemplar foi revisado e corrigido em relação à versão original, sob responsabilidade única do autor e com a anuência de seu orientador.

São Paulo, de de

Assinatura do autor:

Assinatura do orientador:

\section{Catalogação-na-publicação}

Ferreira, Roger Biganzolli

Contribuição para a avaliação da infraestrutura cicloviária do município de São Paulo por meio de parâmetros geométricos e de qualidade de pavimentos

/ R. B. Ferreira -- versão corr. -- São Paulo, 2019. $132 \mathrm{p}$.

Dissertação (Mestrado) - Escola Politécnica da Universidade de São Paulo. Departamento de Engenharia de Transportes.

1.Infraestrutura cicloviária 2.Pavimentos cicloviários 3.Geometria cicloviária 4.Sistemas de Informação Geográfica 5.Sistemas de Gerência de Pavimentos I.Universidade de São Paulo. Escola Politécnica. Departamento de Engenharia de Transportes II.t. 
"As bicicletas não vêm para salvar o mundo, mas talvez já sejam o sinal dos novos mundos que vão surgindo, felizes, lúdicos, lúcidos."

Lama Padma Samten 


\section{RESUMO}

A adoção da bicicleta como modo de transporte traz benefícios econômicos, políticos, energéticos, sociais e ambientais, não apenas aos ciclistas, mas a toda a cidade. Contudo, para a aderência dos cidadãos ao uso da bicicleta, é necessária a oferta de vias cicláveis que garantam conforto e, principalmente, segurança ao usuário. Desta forma, além da implementação de vias cicláveis, o desenvolvimento de pesquisas que discutam formas de avaliação da infraestrutura cicloviária e que subsidiem a delimitação de níveis aceitáveis de adequação é de grande importância.

Tendo como base os elementos dos sistemas de gerência de pavimentos, este trabalho teve como objetivo contribuir para a avaliação da qualidade dos pavimentos e da adequação geométrica das ciclovias e ciclofaixas de uma área piloto de São Paulo (SP).

A avaliação da qualidade dos pavimentos se deu a partir de um catálogo e de um inventário geral de defeitos e patologias de vias cicláveis. Também foram definidos fatores de ponderação entre defeitos de pavimentos cicloviários por meio de um questionário de percepção comparada que subsidiaram os resultados do Índice de Gravidade Global adaptado a Vias Cicláveis (IGGVC). A irregularidade longitudinal foi avaliada por meio das respostas de vibração de um sensor de aceleração vertical embarcado em uma bicicleta, resultando no índice de RMSVA (root mean square vertical acceleration). Estes índices foram correlacionados indicando que vias com mais defeitos, tendem a apresentar valores de RMSVA também maiores.

A adequação geométrica foi avaliada sob três aspectos: larguras, declividades e velocidades. Foram coletadas as larguras médias, calculadas as declividades dos segmentos da área piloto e observadas as velocidades máximas permitidas dos automóveis das vias adjacentes para comparação com intervalos de referência. Estes valores foram integrados no IAGVC (Indicador de Adequação Geométrica Adaptado a Vias Cicláveis), apontando que nenhum segmento é plenamente inadequado, porém, apenas um terço foi classificado como plenamente adequado.

Palavras-chave: Infraestrutura cicloviária; Pavimentos cicloviários; Geometria cicloviária; Sistemas de Informação Geográfica; Sistemas de Gerência de Pavimentos. 


\begin{abstract}
Cycling adoption as a mode of transport brings economic, political, energetic, social and environmental benefits, not only to cyclists, but to the entire city. However, for the citizens' adherence to the use of the bicycle, it is necessary to offer bikeways that guarantee comfort and, mainly, safety to the user. Thus, in addition to the implementation of bikeways, the development of research that discusses ways of assessing cycling infrastructure and supporting the delimitation of acceptable standards is very important.

Based on the pavement management systems components, this work aimed to contribute to the evaluation of the pavement standard and the geometric suitability of the bike lanes and bike paths of a pilot area of São Paulo (SP).

The assessment of pavement standard was based on an catalog and na inventory of bikeway defects and failures. Also, a weighting factors of bikeway pavements defects were defined by a comparative perception questionnaire that supported the results of the Global Gravity Index adapted to Bikeways (IGGVC). Bikeway roughness was assessed by vibration responses of a vertical acceleration sensor embedded in a bicycle, resulting in the root mean square vertical acceleration indicator (RMSVA). These indices were correlated indicating that bikeways with more defects tend to exhibit higher RMSVA values.

Geometric suitability was evaluated under three aspects: widths, slopes and velocity. The average widths were collected, the declivities were calculated, and the maximum allowed speeds of the adjacent streets were observed for comparison with reference ranges. These values were incorporated into the IAGVC indicator (Geometric Suitability Indicator adapted to Bikeways) which showed that no segment of the pilot area is totally inadequate, but only one third were classified as fully adequate.
\end{abstract}

Palavras-chave: Cycling infrastructure; Bikeway pavements; Bikeway geometry; Geographic Information Systems; Pavement Management Systems. 


\section{LISTA DE FIGURAS}

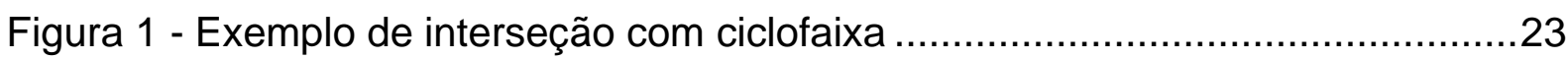

Figura 2 - Gráfico com rampas normais e máximas em função do desnível .............27

Figura 3 - Velocidade e Volume de tráfego e Vias Cicláveis ...................................28

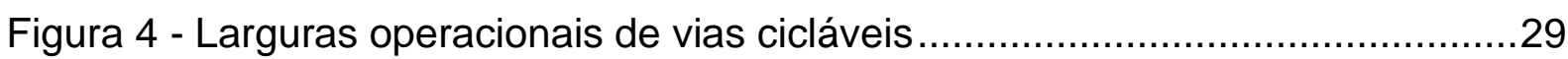

Figura 5 - Totais de quilômetros de vias cicláveis construídas por gestão municipal38

Figura 6 - Mapa da Rede Cicloviária de São Paulo...............................................39

Figura 7 - Ciclovia da Avenida Paulista ........................................................... 41

Figura 8 - Ciclofaixa na Rua Artur de Azevedo ..................................................42

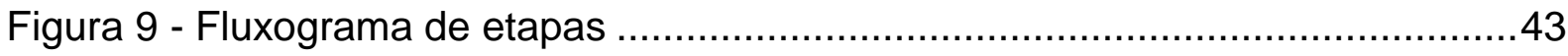

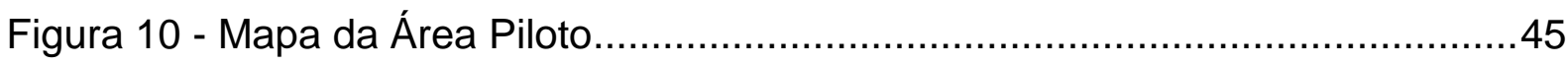

Figura 11 - Obstáculo na Ciclofaixa João Moura ...................................................4

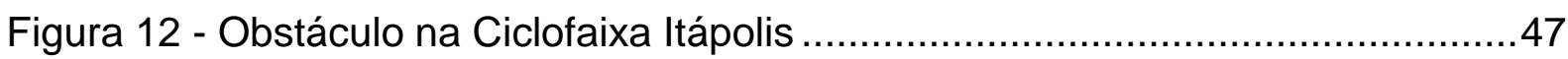

Figura 13 - Mapa situacional da Ciclofaixa Consolação ............................................48

Figura 14 - Mapa situacional da Ciclofaixa Itápolis ...............................................48

Figura 15 - Mapa situacional da Ciclofaixa João Moura .......................................... 49

Figura 16 - Mapa situacional da Ciclofaixa Honduras ........................................... 49

Figura 17 - Mapa situacional da Ciclofaixa Pacaembu / Faap / Pacaembu .............. 49

Figura 18 - Mapa situacional da Ciclovia Faria Lima...........................................50

Figura 20 - Mapa situacional da Ciclofaixa João Ramalho.....................................51

Figura 19 - Mapa situacional da Ciclofaixa Artur de Azevedo ................................51

Figura 21 - Mapa situacional da Ciclovia Pacaembu..........................................51

Figura 22 - Mapa situacional da Ciclovia Paulista ..............................................52

Figura 23 - Mapa situacional da Ciclovia Sumaré .................................................52

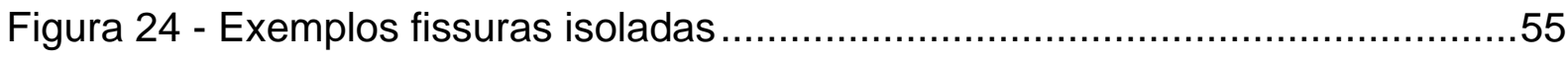

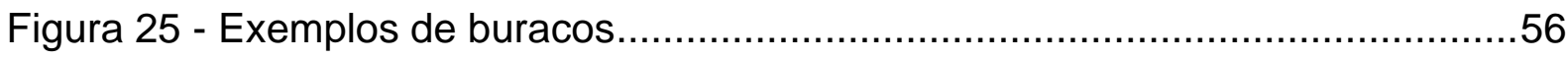

Figura 26 - Exemplos de desgaste da cor do pavimento ………........................57

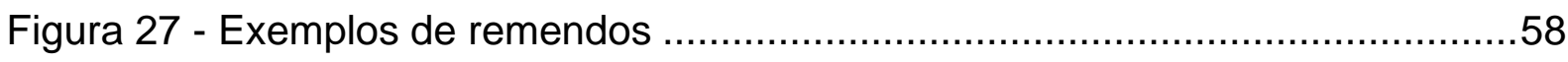

Figura 28 - Exemplos de tampas de poços de visita ou Bocas de Lobo ...................58

Figura 29 - Exemplos de fissuras em blocos....................................................59

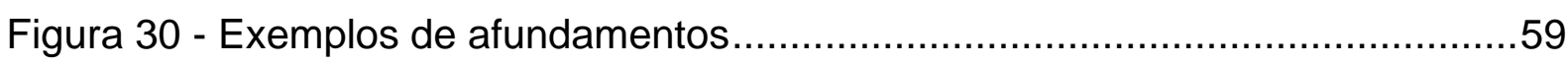

Figura 31 - Exemplos de escorregamentos.......................................................60

Figura 32 - Exemplo de sarjeta como parte da largura útil da via ciclável.................61

Figura 33 - Exemplo de desnível entre via ciclável e sarjeta...................................61 
Figura 34 - Exemplos de grelhas de sarjeta com espaçamento longitudinal. 62

Figura 35 - Exemplos de valetas em intercessões .63

Figura 36 - Exemplos de rampas de acesso de estacionamentos .63

Figura 37 - Exemplos de quebras .64

Figura 38 - Exemplos de esborcinamento de juntas .65

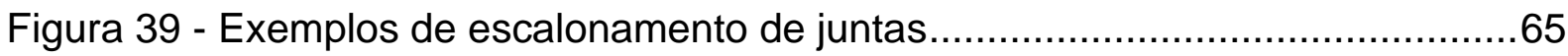

Figura 40 - Exemplos de separação de juntas …………....................................6

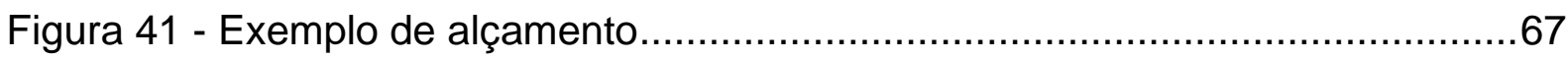

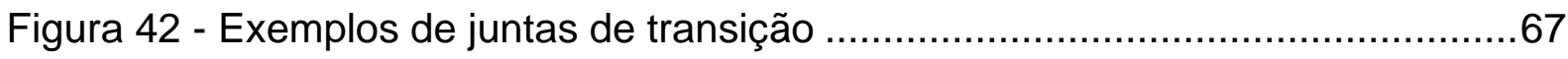

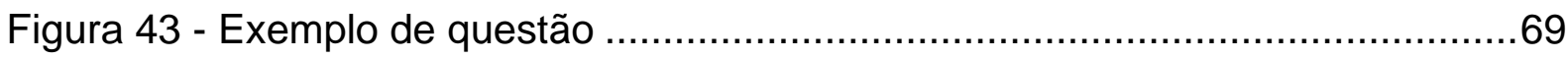

Figura 44 - Mapas das estações do IGGVC da Ciclovia Faria Lima ........................79

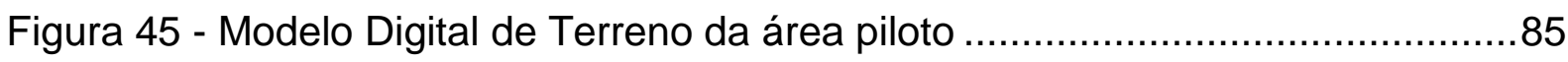

Figura 46 - Gráfico de idades e gênero de ciclistas ...........................................87

Figura 47 - Gráfico de rotina e histórico de uso de ciclistas ...................................8

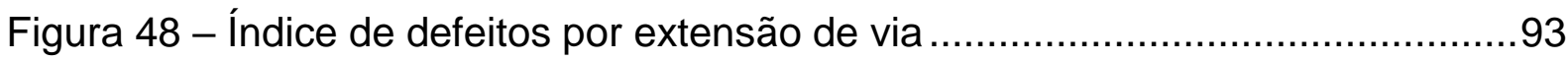

Figura 49 - Mapa de defeitos por extensão para segmentos ...................................94

Figura 50 - Mapa da média de RMSVA por via ciclável ........................................100

Figura 51 - Gráfico de média de RMSVA por segmento ....................................103

Figura 52 - Correlação entre contagens de defeitos/km e RMSVA médio ..............104

Figura 53 - Mapa do resultado do indicador de largura......................................105

Figura 54 - Mapa do resultado do indicador de declividade .................................107

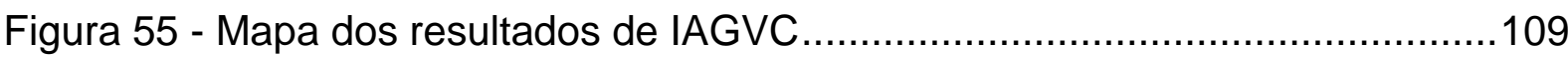




\section{LISTA DE QUADROS}

Quadro 1 - Desempenho comparado entre automóveis, motocicletas e bicicletas ..13

Quadro 2 - Dimensões de tipos de bicicletas .22

Quadro 3 - Largura do espaço cicloviário conforme volume de bicicletas .29

Quadro 4 - Vias cicláveis da área piloto

Quadro 5 - Defeitos e patologias de vias cicláveis .54

Quadro 6 - Ficha do inventário geral de defeitos em pavimentos asfálticos .70

Quadro 7 - Ficha do inventário geral de defeitos em pavimentos de concreto. .70

Quadro 8 - Guia para interpretação de defeitos e patologias em vias cicláveis .71

Quadro 9 - Totais de observações por frequências de aceleração vertical .81

Quadro 10 - Valores de referência do indicador de larguras .83

Quadro 11 - Valores de referência do indicador de velocidades .83

Quadro 12 - Motivo de viagem .87

Quadro 13 - Resumo estatístico do questionário de percepção comparada .88

Quadro 14 - Fatores de ponderação baseados na mediana da amostra 89

Quadro 15 - Segmentação dos fatores de ponderação pela variância da mediana ..90

Quadro 16 - Defeitos e patologias identificados pelo Inventário geral.. .92

Quadro 17 - Resultados do levantamento local para a Ciclovia Faria Lima .95

Quadro 18 - Exemplo parcial de dados brutos de aceleração .97

Quadro 19 - Segmentação de acelerações por coletas x pares de coordenadas .....99

Quadro 20 - Estatística descritiva da distribuição de RMSVA .99

Quadro 21 - Velocidades de coleta de RMSVA dos segmentos analisados 101

Quadro 22 - Resultados de RMSVA por segmento 102

Quadro 23 - Valores médios de larguras identificados. 104

Quadro 24 - Adequação de larguras 105

Quadro 25 -Adequação do indicador de declividade. 106

Quadro 26 - Valores médios, mínimos e máximos de declividade 107

Quadro 27 - Notas para classes de geometria. 108

Quadro 28 - Valores médios, mínimos e máximos de IAGVC 108

Quadro 29 - Adequação do IAGVC 110 


\section{LISTA ABREVIATURAS E SIGLAS}

$\begin{array}{ll}\text { AMECICLO } & \text { Associação Metropolitana de Ciclistas do Recife } \\ \text { CET } & \text { Companhia de Engenharia de Tráfego } \\ \text { CICLOCIDADE } & \text { Associação dos Ciclistas Urbanos de São Paulo } \\ \text { GPS } & \text { Global Position System } \\ \text { IAGVC } & \text { Indicador de Adequação Geométrica Adaptado a Vias Cicláveis } \\ \text { ICC } & \text { Índice de Condição de Ciclovias } \\ \text { ICRNP } & \text { Índice de Condição de Rodovia Não Pavimentada } \\ \text { IDECiclo } & \text { Índice de Desenvolvimento da Estrutura Cicloviária } \\ \text { IF } & \text { Índice de Defeito } \\ \text { IGG } & \text { Índice de Gravidade Global } \\ \text { IGGVC } & \text { Índice de Gravidade Global adaptado a vias cicláveis } \\ \text { IGI } & \text { Índice de Gravidade Individual } \\ \text { IGIVC } & \text { Índice de Gravidade Individual adaptado a Vias Cicláveis } \\ \text { IRI } & \text { International Roughness Index } \\ \text { ITRE } & \text { Institute for Transportation Research and Education } \\ \text { MDT } & \text { Modelo Digital de Terreno } \\ \text { PCI } & \text { Pavement Condition Index } \\ \text { RMSVA } & \text { Root mean square vertical acceleration } \\ \text { SGP } & \text { Sistemas de Gerência de Pavimentos } \\ \text { SIG } & \text { Sistema de Informação Geográfica } \\ \text { SUS } & \text { Sistema Único de Saúde } \\ \text { TxDot } & \text { Texas Department of Transportation } \\ \text { VSA } & \text { Valor de Serventia Atual }\end{array}$




\section{SUMÁRIO}

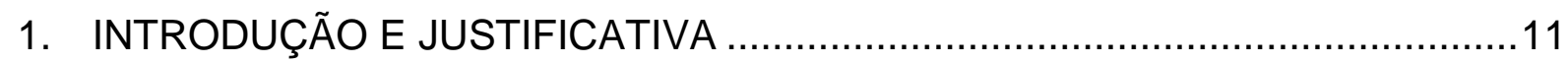

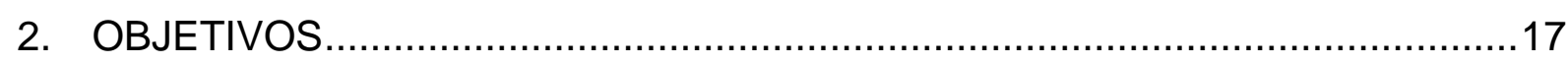

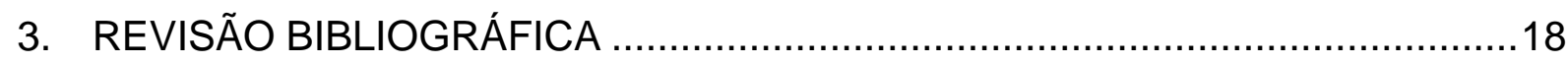

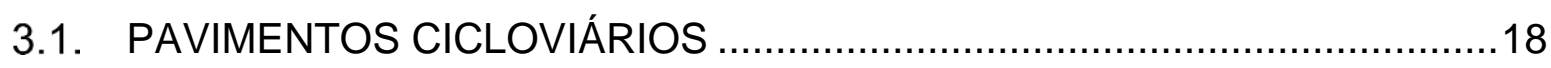

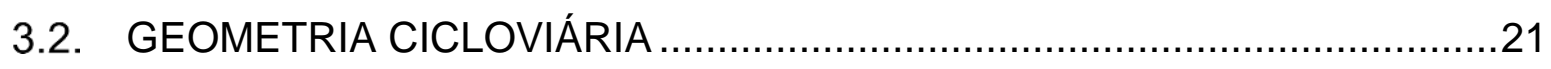

3.3. SISTEMAS DE GERÊNCIA DE PAVIMENTOS E REDE CICLOVIÁRIA .....30

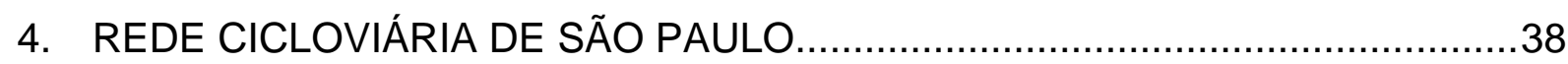

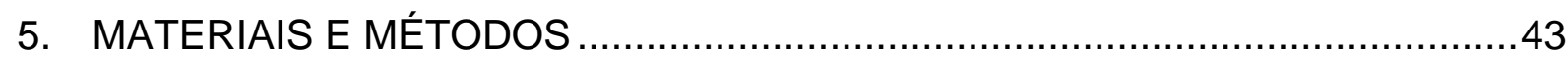

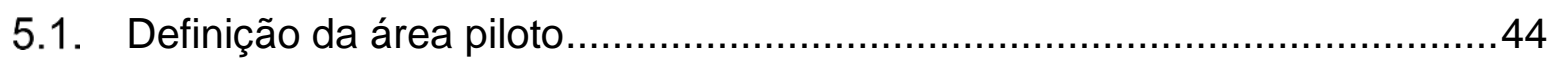

5.2. Avaliação da qualidade dos pavimentos das vias cicláveis........................52

5.2.1. Diagnóstico de defeitos e patologias ................................................53

5.2.2. Indicador de irregularidade longitudinal de vias cicláveis .....................79

5.3. Avaliação da adequação geométrica das vias cicláveis ..............................82

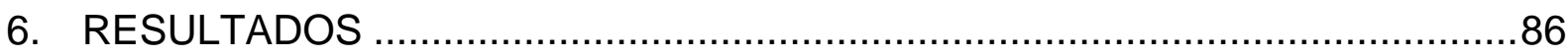

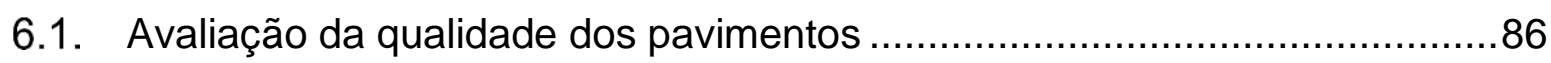

6.1.1. Questionário de percepção comparada e fatores de ponderação .........86

6.1.2. Inventário geral e diagnóstico de defeitos e patologias .........................91

6.1.3. Levantamento local de defeitos e patologias e IGGVC .......................95

6.1.4. Diagnóstico de irregularidade longitudinal (RMSVA) ...........................97

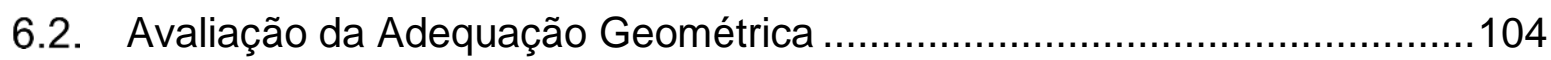

6.2.1. Diagnóstico de adequação geométrica (IAGVC) …...........................108

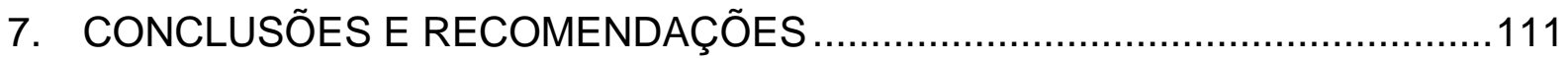

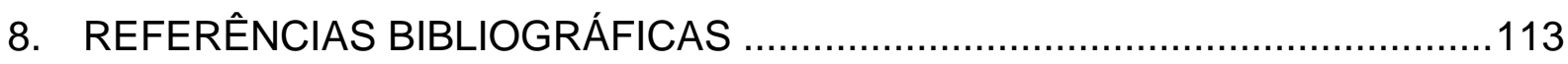

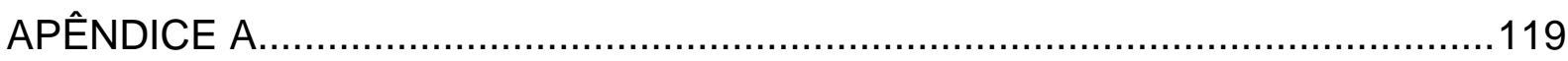

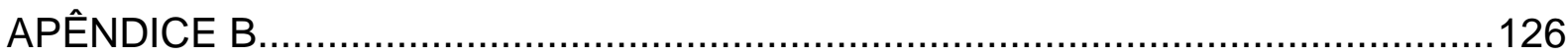




\section{INTRODUÇÃO E JUSTIFICATIVA}

A bicicleta, mesmo que tenha sido criada há mais de dois séculos, possui um potencial de transporte nas cidades bastante significativo e que foi subestimado ao longo da história. Suas características, de forma geral, não foram consideradas no planejamento de transportes e, consequentemente, no planejamento urbano de muitos centros em todo o mundo.

"A maioria dos formuladores de políticas urbanas age como se 0 automóvel fosse o desejo natural e o destino de todas as pessoas; como se, assim que pudessem, todos os pedestres e usuários do transporte coletivo fossem migrar para a motocicleta ou para o automóvel". (IEMA, 2009, p. 12).

Desde o início do século $\mathrm{XX}$, o incentivo aos modos individuais motorizados resultou em várias questões e conflitos urbanos: como a contaminação do ar, a dificuldade do acesso à cidade por parte dos indivíduos não motorizados, o acréscimo no valor da terra e a gentrificação e, o mais claro e cotidiano, os congestionamentos.

Esta mesma lógica de valorização dos automóveis, responde aos engarrafamentos com o aumento da capacidade das vias e a criação de ruas e avenidas adicionais para proporcionar maior fluidez ao tráfego dos veículos. Esta fluidez atrai mais carros para o sistema viário, o que, futuramente, causa novos congestionamentos, que demandam novos alargamentos e a criação de ruas e avenidas. Este ciclo se reproduz de forma contínua ao longo dos anos, o que se esbarra no fato de que o território das cidades tem seu limite e o tecido urbano é finito (GUALDA, 1994).

Neste contexto, os modos ativos de transporte representam uma possibilidade alternativa, que complementa e até subverte a lógica tradicional dos planejadores urbanos. Eles garantem a mobilidade de todas as pessoas, independentemente da sua idade ou características físicas, e podem ser uma forma efetiva de reduzir a dependência do automóvel (AMIGO, 2018).

"O andar a pé e o andar de bicicleta como modos de transporte vêm ganhando destaque nas discussões sobre o desenvolvimento mais sustentável das cidades brasileiras com um olhar mais humano, de uma cidade para pessoas, contrapondo-se ao planejamento 
rodoviarista de formação das grandes cidades. Dessa forma, é fundamental, e, sobretudo, já previsto em lei [...] que o transporte ativo seja pauta dos planejadores em transporte e mobilidade." (MASCARENHAS, 2018, p. 128).

O uso cotidiano da bicicleta como modo de transporte (para além do esporte e da recreação), traz muitos benefícios para os indivíduos e para a cidade. Segundo a Comissão Europeia (2000), os pontos positivos do incentivo e do uso de bicicletas nas cidades são inúmeros e vão além da capacidade de transportar pessoas, incluindo vantagens econômicas, políticas, energéticas, sociais e ambientais.

Por conta da bicicleta se tratar de um veículo de baixo custo de aquisição (comparado a veículos automotores) e de operação (dado que não há necessidade de combustível fóssil ou elétrico), além da não necessidade de registro ou controle rígido das agências de trânsito, ela é capaz de promover a inclusão social, sobretudo da população de baixa renda, ao ampliar o acesso dos cidadãos às atividades e aos equipamentos sociais e urbanos como escolas, centros culturais, hospitais, locais de emprego etc. Ademais, toda a dinamização de fluxos que a bicicleta proporciona a torna um instrumento de percepção e apropriação do espaço público de todos os cidadãos, independentemente da faixa de renda, aumentando o acesso ao consumo e produção de bens e serviços na cidade (CALLIL, 2018; IEMA, 2009).

No quadro 1 há a comparação do desempenho do uso da bicicleta em meio urbano com motocicletas e automóveis em vários critérios. Nota-se que, mesmo com baixos desempenhos nos critérios de "segurança do usuário" e de "capacidade de carga", a bicicleta possui alto desempenho na eficiência energética a baixos custos, ocorrendo o oposto nestes mesmos critérios aplicados ao desempenho de automóveis.

Além de benefícios para os ciclistas, também são indicadas vantagens econômicas bastante imediatas para toda a cidade. Isto se dá porque uma infraestrutura cicloviária de qualidade pode estimular mais pessoas a fazer viagens utilizando a bicicleta deixando de usar os carros e, assim, aliviar parte do congestionamento marginal nas cidades (HÖLZEL, 2012; ITDP Brasil, 2013).

Como exemplo, Gössling e Choi (2015) demostraram que um quilômetro de deslocamento por carro custam à cidade de Copenhagen (Dinamarca) seis vezes mais que o mesmo deslocamento por bicicleta, em se tratando de métricas 
relacionadas a vários eixos (tempo de viagem, custos operacionais do veículo, saúde, acidentes, promoção do turismo, entre outros).

Quadro 1 - Desempenho comparado entre automóveis, motocicletas e bicicletas

\begin{tabular}{|l|c|c|c|c|}
\hline \multirow{2}{*}{\multicolumn{1}{|c|}{ Critérios }} & \multicolumn{3}{c|}{ Desempenho } & \multirow{2}{*}{ Observações } \\
\cline { 2 - 4 } & Automóvel & Moto & Bicicleta & \\
\hline Consumo de combustível & Alto & Médio & - & \\
\hline Eficiência energética & Baixa & Baixa & Alta & Energia/usuário/km \\
\hline Segurança do usuário & Média & Baixa & Baixa & \\
\hline Taxa de ocupação & Baixa & Média & Alta & Ocupação média/capacidade \\
\hline Flexibilidade de utilização & Baixa & Média & Alta & \\
\hline Capacidade de carga & Alta & Média & Baixa & \\
\hline Velocidade porta-a-porta & Variável* & Alta & Alta & \\
\hline Demanda espaço público & Alta & Média & Baixa & \\
\hline Custo para a comunidade & Alto & Baixo & Baixo & Infraestrutura, energia etc. \\
\hline Custo para o usuário & Alto & Médio & Baixo & Aquisição e manutenção \\
\hline Perturbação ambiental & Alta & Alta & - & \\
\hline Contribuição à saúde & - & - & Alta & Saúde física e gases \\
\hline Conforto do usuica & Alto & Médio & Baixo & \\
\hline Status do usuário & Alto & Médio & Baixo & \\
\hline
\end{tabular}

*Depende do tráfego e da facilidade de estacionamento

Fonte: GEIPOT, 2001

Benefícios econômicos diretos também estão relacionados à cadeia produtiva e comercial do mercado ciclístico. O incentivo ao uso da bicicleta como meio de transporte pode afetar o comércio local com o surgimento de bicicletarias e estabelecimentos destinados a venda e produção de equipamentos auxiliares de ciclismo. Há também a tendência do surgimento do turismo ciclístico, em que os visitantes encontram mais uma forma de se conectar com a cidade, seja com passeios guiados ou com o próprio uso para o deslocamento (sobretudo com os sistemas de compartilhamento de bicicletas).

Os impactos positivos que atuam sobre a saúde da população são notáveis tanto na melhoria de indicadores pessoais de atividade física quanto nos custos do sistema de saúde das administrações públicas (CALLIL, 2018).

Segundo as informações levantadas por Torres-Freire et al. (2018), o uso da bicicleta como meio de transporte parece refletir diretamente o nível de atividade de física da população de forma geral: a inatividade (categoria das pessoas que não realizaram atividades físicas moderadas ou vigorosas na semana anterior à 
pesquisa) atinge 25\% da população da cidade de São Paulo, enquanto entre os ciclistas, ela não passa de $3 \%$. Estes autores também verificaram qual seria 0 potencial de economia no Sistema Único de Saúde (SUS) com o tratamento de doenças circulatórias e cardiovasculares caso os paulistanos aderissem aos índices de atividade física dos ciclistas: foi projetada uma economia de $\mathrm{R} \$ 34$ milhões (13\% do total gasto no ano de 2016) no tratamento destas doenças muito relacionadas ao sedentarismo e à inatividade.

Em se tratando dos impactos positivos que a adoção da bicicleta como modo de transporte causa no meio ambiente, pode-se elencar a não necessidade de combustíveis fósseis para a operação; a não emissão de gases poluentes na atmosfera; a baixa produção de ruídos (em comparação aos veículos automotores); a baixa geração de resíduos na produção e manutenção das bicicletas, além de serem feitas de materiais facilmente recicláveis (IDAE, 2007).

Torres-Freire et al. (2018) também apresentaram dados acerca da diminuição das emissões de $\mathrm{CO}_{2}$ na atmosfera por conta da substituição teórica de viagens "pedaláveis" e "facilmente pedaláveis"1 realizadas em carros e em ônibus por bicicletas em São Paulo. Constatou-se que esta troca poderia gerar uma diminuição de $8 \%$ da emissão realizada por ônibus e a redução de $10 \%$ de toda a emissão realizada por carros (baseado nos dados da pesquisa OD do Metrô de 2007).

Não obstante, para que todos esses benefícios possam ocorrer na cidade é importante que haja um real engajamento dos cidadãos no modo de transporte cicloviário. Em linhas gerais, a aderência ao sistema cicloviário é definida pela decisão do próprio usuário, que pode oscilar dia após dia por muitos motivos, pois muitas externalidades ao sistema o influenciam diretamente.

É importante considerar os aspectos qualitativos dessas decisões para que se possa construir um planejamento mais aderente à realidade. Chapadeiro (2011) diferencia em três tipos de fatores que influenciam a tomada de decisão do usuário na utilização do sistema cicloviário nas cidades: socioculturais, humanos e do ambiente físico.

Os fatores socioculturais estão associados tanto a como a sociedade reconhece a bicicleta como um modo de transporte eficiente e seguro, a existência

\footnotetext{
${ }^{1}$ Os autores consideram viagens "pedaláveis" como sendo aquelas de até $8 \mathrm{~km}$, realizadas entre $6 \mathrm{~h}$ e $20 \mathrm{~h}$ por pessoas com até 50 anos; e as viagens "facilmente pedaláveis" como sendo aquelas que são de até $5 \mathrm{~km}$, realizadas entre $6 \mathrm{~h}$ e $20 \mathrm{~h}$, por pessoas com até 50 anos.
} 
de políticas e incentivos por parte dos agentes públicos ao construir e fortalecer uma cultura de transportes não motorizados.

Os fatores humanos estão mais vinculados às características, capacidades e percepções do próprio indivíduo, como a idade do usuário, o motivo de viagem e as habilidades e condicionamento físico.

Os fatores do ambiente físico se relacionam às características parcialmente passíveis de interferência ou modificações que, muitas vezes, se apresentam como obstáculos ou facilitação para os ciclistas. Como exemplo: as distâncias entre a origem e o destino; a declividade, o clima e o regime de chuvas. Ademais, o autor também considera nesta classificação a ocorrência de vias destinadas a bicicletas (de forma compartilhada ou exclusiva) e a existência de elementos de segurança cicloviária.

Certamente, implantar e manter uma rede cicloviária com o objetivo de aumentar a participação de pessoas para este modo de transporte vai muito além de apenas criar vias, mas se devem levar em consideração os vários aspectos que interferem no fluxo de um ciclista na cidade. Contudo, mesmo que as muitas externalidades a um sistema cicloviário causem várias consequências, a segurança cicloviária é a de maior impacto na população.

A incorporação no código de trânsito brasileiro em 1997 de regras que consideram a circulação de bicicleta (como distância mínima de circulação entre veículos motorizados e ciclistas) foi um avanço neste aspecto, mas a demanda pela construção de vias cicláveis ainda está associada à necessidade de garantir mais segurança para os ciclistas (Vasconcellos, 2014).

Amigo (2018), em uma pesquisa qualitativa sobre a aderência da bicicleta na população de São Paulo, indica que a sensação de vulnerabilidade é muito forte e a falta de segurança define como o potencial ciclista opta por não usar a bicicleta na cidade. Nos relatos levantados, foi apresentado que, mesmo com a implementação de ciclovias e ciclofaixas, há uma sensação de medo, sobretudo relacionado à falta de interligação entre as vias cicláveis, fazendo com que o ciclista tenha que ir para os espaços dedicados aos veículos motorizados. Estes, por sua vez, estão em elevado número, transitam em altas velocidades e apresentam comportamento agressivo no trânsito, dissuadindo a decisão do uso da bicicleta, mesmo com a existência de vias cicláveis na cidade. 
Para além de se evitar conflitos e acidentes, também há de ser considerado o conforto do ciclista na implantação de infraestruturas cicloviárias, como aspecto que os atraia para este modo de transporte. Vias cicláveis de qualidade devem oferecer um rolamento suave, com baixas taxas de vibração e baixo consumo de energia (HÖLZEL, 2012).

No tocante ao planejamento das cidades e o desenvolvimento de políticas públicas, a implantação da infraestrutura cicloviária e de programas sistemáticos de manutenção são caminhos possíveis para aumentar a aderência da população e de diminuir a vulnerabilidade dos ciclistas. Contudo, a produção de conhecimento técnico e acadêmico específico sobre o tema é de suma importância, dado que historicamente, as perspectivas dos planejadores inseriam apenas os veículos motorizados no centro das discussões sobre transportes.

Em se tratando do estado da arte, a maioria da bibliografia disponível sobre a bicicleta como meio de transporte data dos últimos 30 anos e, no caso brasileiro, começam a aparecer nos anos 2000, com mais frequência a partir de 2010, o que indica que há um vasto espaço para a produção de conhecimento científico e técnico no tema da mobilidade por bicicleta. E, especificamente sobre estratégias de manutenção e reabilitação, é importante avaliar a qualidade da rede cicloviária e dedicar tempo e recursos a este processo, que deve ser realizado de maneira periódica (Callil, 2018; ITDP Brasil, 2015).

Desta forma, o presente trabalho pretende contribuir para o preenchimento das lacunas que se vinculam aos tópicos de qualidade de pavimentos e aos elementos geométricos da rede cicloviária, dado que esses são um dos pontos mais importantes nos projetos de vias cicláveis, pois a sua escolha e manutenção corretas impactam diretamente na segurança e conforto do ciclista (BARBUDO et al., 2015). 


\section{OBJETIVOS}

O objetivo geral deste trabalho é avaliar a qualidade da infraestrutura cicloviária em ciclovias e ciclofaixas de uma área piloto do município São Paulo, SP, a partir de indicadores de qualidade de pavimentos e adequação geométrica.

Para tanto, são propostos quatro objetivos específicos:

a) Definição de fatores de ponderação entre defeitos e patologias de pavimentos cicloviários por meio de questionário de percepção comparada;

b) Avaliação de índices de defeitos e patologias nas vias cicláveis da área piloto;

c) Avaliação da irregularidade longitudinal dos pavimentos da área piloto por meio de indicador de aceleração vertical;

d) Avaliação de indicadores de adequação geométrica cicloviária na área piloto. 


\section{REVISÃO BIBLIOGRÁFICA}

\subsection{PAVIMENTOS CICLOVIÁRIOS}

Por definição, "os pavimentos são uma estrutura de múltiplas camadas de espessuras finitas, construída sobre a superfície final de terraplenagem, destinada técnica e economicamente a resistir aos esforços oriundos do tráfego de veículos e do clima, e a propiciar aos usuários melhoria nas condições de rolamento, com conforto, economia e segurança" (BERNUCCl et al., 2006, p. 9).

A pavimentação tem por objetivo garantir a trafegabilidade em qualquer época do ano e condição climática, além de oferecer uma superfície regular, diminuindo o desconforto do tráfego, aderente, diminuindo o risco a derrapagens e garantindo a segurança, e menos ruidosa, fornecendo maior conforto ambiental nas vias urbanas e rodovias. (BALBO, 2016; BERNUCCI et al., 2006)

Os pavimentos rodoviários ocupam lugar central nas infraestruturas viárias e 0 desenvolvimento de tecnologias nesta área do conhecimento tem por objetivo primordial a observação do seu comportamento no tempo e no espaço. Esta perspectiva não é diferente para os pavimentos cicloviários, dado que a qualidade da pavimentação das infraestruturas ciclísticas se relaciona diretamente com o conforto e a segurança do tráfego de ciclistas (ITDP, 2015; SOLMINIHAC-TAMPIER, 2001).

As definições dos tipos de pavimentos rodoviários existentes passam por compreensões de diferentes autores e instituições, contudo pode-se segmentar em dois grupos principais: os pavimentos asfálticos (muitas vezes denominados flexíveis) e pavimentos de concreto (muitas vezes denominados rígidos). Os primeiros são construídos por camadas de rolamento elaboradas com algum tipo de mistura, o que thes confere um maior e mais expressivo deslocamento vertical elástico (deflexão) se comparados com os pavimentos rígidos, que são revestidos por placas de concreto de cimento Portland, podendo ser armadas ou não por barras de aço (BALBO, 1997; BERNUCCl et al., 2006).

Em se tratando de pavimentos cicloviários, Crow (2007) e Barbudo et al. (2015) acompanham estas duas classificações, mas também indicam a implementação de pavimentos intertravados (Adoquín ou Baldosas, Concrete Tiles ou Paviours) para as vias cicláveis. Contudo, também se indica que existe uma clara preferência dos ciclistas por pavimentos contínuos, dado que estes oferecem uma maior 
uniformidade, menores resistências ao rolamento e, consequentemente, maior conforto.

Como são estruturas que são afetadas diretamente pelo ambiente e pelo tráfego de veículos, os pavimentos evoluem ao longo do tempo e se deterioram, dando origem a defeitos e patologias. Segundo Balbo (1997), os defeitos que ocorrem em pavimentos podem ter várias origens, dentre elas, rupturas por resistência, rupturas por fadiga, por deformação plástica, por retração hidráulica, retração térmica etc. Grande parte deles está associado à perspectiva estrutural do pavimento, que se relaciona com desgastes e deformações relativos à repetição de carga dos veículos automotores (BERNUCCI et al., 2006).

Segundo Barbudo et al. (2015), para as vias cicláveis, não se pode afirmar que as cargas a que são expostas (a soma do ciclista e a bicicleta) poderiam deteriorar de forma significativa o pavimento com sua massa. Não obstante, para vias cicláveis em pavimentos flexíveis (que em São Paulo são representados pelas ciclofaixas), pode-se considerar as cargas dos veículos de manutenção, casos esporádicos de invasão dos carros do viário adjacente, ou mesmo a herança de problemas da pavimentação das vias de automotores. Acerca dos aspectos funcionais dos defeitos que ocorrem em vias cicláveis, a aderência do contato entre o pneu o pavimento representa um dos elementos que mais afetam a segurança cicloviária, haja vista que impacta diretamente no risco a derrapagem, na frenagem, na aceleração e na trajetória da curva.

Ainda sob o aspecto funcional do pavimento, a condição da superfície é muito importante, pois os defeitos e as irregularidades da superfície afetam diretamente o conforto do usuário. Especificamente sobre os ciclistas, uma superfície viária de baixa qualidade é um fator que os afeta fortemente, sendo decisiva para a escolha de rotas nas cidades. (BERNUCCl et al., 2006; BíL et al., 2015).

Atualmente não há uma norma oficial ou que seja largamente adotada para a avaliação específica de defeitos em vias cicláveis. Contudo, existem muitos métodos de identificação e mensuração de defeitos e patologias descritos na bibliografia de pavimentos rodoviários e nas normas brasileiras. Para os pavimentos de concreto, o principal método é o $\mathrm{PCl}$ (Pavement Condition Index), que se utiliza de uma escala de avaliação com intervalo de 0 a 100. Por meio da inspeção visual dos pavimentos, desta escala são deduzidos valores que representam o tipo, ocorrência e severidade dos defeitos. Estes resultados classificam a superfície do pavimento em 7 classes 
(de "excelente" a "rompido"), que indicam as melhores integridades do pavimento para os escores próximos a 100 (BALBO, 2016).

Também por meio de inspeções in loco, o IGG (Índice de Gravidade Global) afere sistematicamente a ocorrência de defeitos em pavimentos asfálticos. São utilizadas planilhas em que são registradas se há ou não determinada patologia em estações ao longo da via (com $6 \mathrm{~m}$ de extensão e largura igual a da faixa a ser avaliada). Em seguida, este levantamento é relacionado com fatores de ponderação para cada tipo de defeito, que comparam o impacto que estes causam na qualidade viária. Para além de quantificar a qualidade do pavimento, este método consegue indicar segmentos homogêneos, resultado muito importante para se ter a informação espacial da disposição dos defeitos ao longo da via. (BALBO, 1997; BERNUCCI et al., 2006).

Outro parâmetro muito importante para a qualidade dos pavimentos cicloviários é a adequação da irregularidade superficial: como a vibração gerada pelo contato entre o pneu e o pavimento é transmitida pelo guidão e selim ao ciclista, ela afeta o conforto da condução da bicicleta. Mesmo que as velocidades dos ciclistas sejam relativamente baixas se comparadas com os veículos automotores, o sistema de absorção de impacto é muito mais simples, o que resulta em uma sensibilidade maior para o ciclista em pavimentos com alta irregularidade (BARBUDO et al., 2015, CHOU et al., 2015).

Por se tratar de um conceito amplo, a irregularidade superficial pode ser mensurada a partir de algumas abordagens. Uma métrica mais subjetiva é o VSA (Valor de Serventia Atual), que se constitui pela opinião de usuários e técnicos calibrados sobre a qualidade e o conforto ao rolamento nos pavimentos. A partir do percurso com o veículo, os entrevistados devem indicar em 5 classes ("excelente" a "péssimo") qual sua percepção sobre os pavimentos (BERNUCCI et al., 2006).

De forma mais objetiva, a irregularidade superficial também é mensurada por meio de sistemas do tipo resposta. Um exemplo comumente utilizado é perfilômetro inercial a laser, composto basicamente por um veículo em que são instalados sistemas medidores de aceleração vertical (acelerômetro) e sensores de medição sem contato (laser) que medem a variação da distância da carroceria até o pavimento subsidiando os cálculos de índices de irregularidade, como o $|R|$ (International Roughness Index) (BARELLA, 2008; SAYERS e KARAMIHAS, 1998). 
O IRI, que descreve a irregularidade superficial ao longo da pista que causa vibrações ao veículo, foi desenvolvido na tentativa de se padronizar as várias escalas, técnicas e equipamentos de mensuração diferentes no mundo. Em aspectos formais, ele é definido como o índice entre o somatório dos deslocamentos ocorridos na suspensão de um veículo dividido pela distância percorrida (BALBO, 1997; SAYERS e KARAMIHAS, 1998).

Pelos custos e facilidade de operação e produtividade, alguns trabalhos buscam encontrar outras formas de se avaliar objetivamente a qualidade do rolamento em vias pavimentadas. Bisconsini (2016) apresenta um método alternativo de mensuração de irregularidade longitudinal, que barateia e aumenta as possibilidades de coletas e avaliação. O autor se utilizou de dispositivos de GPS (Global Position Systems) atrelados a acelerômetros instalados em smartphones, para captar as respostas vibracionais de um carro. Estas repostas foram representadas pelo cálculo de RMSVA (root mean square vertical acceleration) ou raiz da média quadrática dos sinais de aceleração vertical do trajeto de automóveis em algumas vias em determinadas velocidades. Com este indicador, foi possível comparar os valores de RMSVA com os de IRI, também coletados nas mesmas condições, indicando como satisfatória a adoção desse índice como outra forma de avaliação da irregularidade longitudinal.

É importante ter em mente que a irregularidade superficial é, de forma geral, avaliada com base na resposta vibracional de um modelo de "quarto-de-carro" trafegando a $80 \mathrm{~km} / \mathrm{h}$. Alguns autores questionam a aplicação do IRI como medida irregularidade para vias cicláveis dado as notáveis diferenças de velocidade, pressão e frequência da circulação entre automóveis e bicicletas. Assim, propõem que a irregularidade seja avaliada por meio de simulações com bicicletas, que são os veículos que efetivamente serão afetados pela má qualidade do pavimento (Chou et al., 2015).

\subsection{GEOMETRIA CICLOVIÁRIA}

Existem muitos tópicos que envolvem os projetos geométricos de vias cicláveis, contudo, para a presente pesquisa, que se direciona aos aspectos funcionais a partir de uma perspectiva gerencial de uma rede cicloviária, pretende-se discutir pontos 
críticos da geometria de vias cicláveis que mais se relacionam com a garantia da operação e, sobretudo, com a segurança cicloviária. A seguir, são apresentadas as principais características geométricas que dão subsídio aos projetos de infraestrutura cicloviária.

Por conta da diversidade de usuários e respectivos motivos de locomoção, muitos tipos de bicicletas foram desenvolvidos ao longo da história sem uma regulamentação limitante tão específica como a de veículos automotores. Suas dimensões e velocidades atingidas variam bastante, mas todas possuem a característica de serem movidos parcial ou totalmente pela força humana sobre pedais e rodas (AASHTO, 2012). É importante ressaltar que nesta definição também se encaixam as bicicletas elétricas ou motorizadas, que possuem um motor auxiliar que é ativado ou não em função da solicitação do ciclista.

Ainda que os usos das vias cicláveis podem ir além de bicicletas para adultos (como bicicletas infantis, triciclos, cadeiras de rodas) e não existe uma regulamentação que defina uma convenção de um veículo de projeto geométrico para vias cicláveis, é importante considerar algumas dimensões de modelos e tipos de veículos cicloviários, como mostra o quadro 2.

Quadro 2 - Dimensões de tipos de bicicletas

\begin{tabular}{|l|c|c|c|c|c|}
\hline \multicolumn{1}{|c|}{ Tipo } & $\begin{array}{c}\text { Comprimento } \\
(\mathbf{c m})\end{array}$ & $\begin{array}{c}\text { Altura } \\
(\mathbf{c m})\end{array}$ & $\begin{array}{c}\text { Largura do } \\
\text { Guidão } \mathbf{( c m )}\end{array}$ & $\begin{array}{c}\text { Diâmetro da } \\
\text { Roda }(\mathbf{c m})\end{array}$ & $\begin{array}{c}\text { Largura do } \\
\text { pneu (cm) }\end{array}$ \\
\hline Bicicleta de cicloturismo & $180-195$ & $100-120$ & $50-60$ & $66-72$ & $3,7-4,0$ \\
Bicicleta de velocidade & $170-190$ & $100-120$ & $45-60$ & $66-72$ & $2,5-3,0$ \\
Bicicleta de montanha & $170-190$ & $95-110$ & $60-55$ & $66-72$ & $4,0-5,0$ \\
Bicicleta infantil & $150-170$ & $80-100$ & $50-55$ & $66-72$ & $3,6-3,8$ \\
Bicicleta reclinada & $170-220$ & $40-60$ & $60-70$ & - & - \\
\hline
\end{tabular}

Fonte: Traduzido de CROW, 2007

DiGioia et al. (2017) sintetizam os objetivos de projetos geométricos de vias que focam em reduzir o número ou a severidade de colisões entre veículos motorizados e não motorizados da seguinte maneira: a) aumento das segregações entre bicicletas e veículos automotores no espaço e no tempo; b) melhoria na visibilidade entre os veículos e usuários; c) diminuição no número de interações intermodais; e d) redução das velocidades dos veículos automotores. Estes objetivos 
norteiam a seguinte discussão sobre intercessões, velocidades, declividades, e larguras em projetos de vias cicláveis.

As intercessões merecem especial atenção dos projetistas de vias, pois são pontos especialmente perigosos, já que se cruzam fluxos em velocidades muito distintas: de um lado veículos entrando, saindo ou cruzando, e por outro, veículos em velocidade maior transitando pela via (SOLMINIHAC-TAMPIER, 2001).

Sendo assim, as interseções são elementos geométricos de extrema importância para a segurança cicloviária, haja vista que são onde os ciclistas estão mais expostos a pedestres e veículos automotores, aumentando as chances de conflitos e acidentes.

Para que a operação intermodal em interseções ocorra de forma efetiva, é importante a atenção a alguns requisitos em projetos geométricos, como: "diretividade", do inglês directness, que se relaciona com menores tempos ou distâncias para o cruzamento; "segurança", com a minimização de conflitos e garantia de visibilidade; "conforto e coesão", com a garantia de pavimentação contínua e com sinalização padronizada (CROW, 2007). Ademais, para garantir a segurança viária em interseções de múltiplos modos, devem-se levar em consideração outros elementos que envolvam as diferentes capacidades de manobra dos usuários e suas percepções de segurança.

Figura 1 - Exemplo de interseção com ciclofaixa

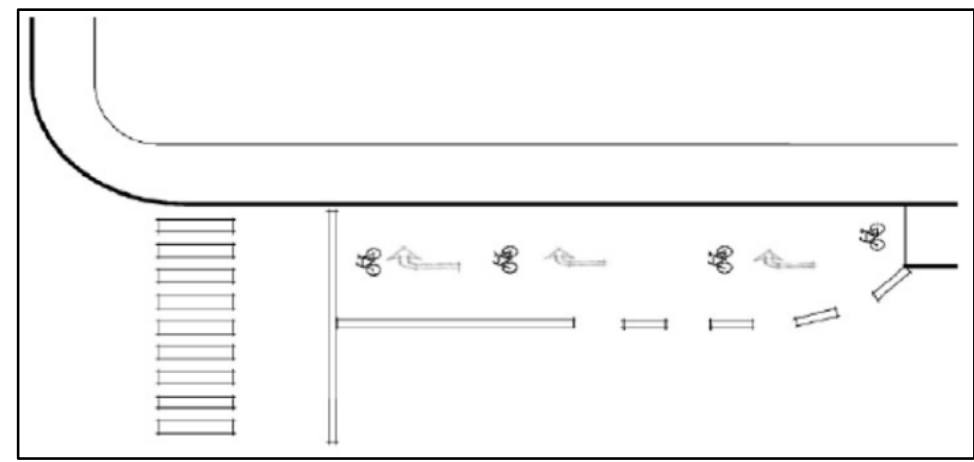

Fonte: Madsen e Lahrmann (2017)

Madsen e Lahrmann (2017) exemplificam estes critérios e elementos ao avaliarem a segurança cicloviária de cinco tipos de projetos de interseções na Dinamarca a partir da captura de vídeos de momentos de conflitos entre carros e bicicletas. Seus resultados indicaram que o projeto de interseção do tipo "Ciclovia" é 
o mais seguro, devido ao maior nível de segregação e à travessia ocorrer junto à faixa de pedestres. Já o projeto em "Ciclofaixa tracejada combinada com faixa de conversão à direita" (figura 1) se mostrou como o menos seguro por conta da fusão de faixas entre o motorista e o ciclista antes da conversão que promove menores distâncias transversais e, consequentemente, menor visibilidade entre os usuários.

Outros tipos de conflitos em interseções foram apresentados por Flannery et al. (2010). Os autores analisaram o comportamento e a percepção de ciclistas e pedestres em cinco rotatórias de múltiplas faixas em algumas localidades dos Estados Unidos, além de discutir as geometrias de projetos ideais para estes tipos de interseções.

Em seus resultados, nas rotatórias em que a percepção de segurança era maior, foi verificado que os ciclistas não compartilhavam as vias com os automóveis, mas se utilizavam dos passeios e calçadas destinadas aos pedestres. Dessa forma, o estudo indica que esforços para a construção de dispositivos compartilhados entre pedestres e ciclistas pode ser uma solução para a integração de modos em rotatórias de múltiplas faixas.

Outro resultado importante se refere ao diferencial de velocidade entre carros e bicicletas: quanto maior a diferença, maior é a percepção de insegurança. As altas velocidades dos automóveis induzem os ciclistas a manterem as faixas da direita, onde são praticadas menores velocidades, mas também são onde ocorrem as entradas e saídas dos veículos nas rotatórias. Segundo os autores, sugerem-se velocidades máximas de $32 \mathrm{~km} / \mathrm{h}$ nas aproximações e na circulação de rotatórias em que se espera a presença de ciclistas.

Contudo, o elemento principal que afeta a segurança em interseções é a garantia da visibilidade. Ela está relacionada com as dimensões dos elementos geométricos, com a presença dos dispositivos de segurança e, principalmente, com as velocidades praticadas nas aproximações: quanto mais rápido ocorrem as conversões ou mudanças de faixas, menor é o tempo de reação dos ciclistas e dos motoristas para que acidentes sejam evitados.

Ainda em se tratando sobre os impactos das velocidades praticadas pelos veículos automotores sobre os ciclistas, DiGioia et al. (2017) indicam que, quando ocorrem colisões, se há um menor diferencial de velocidades entre carros e ciclistas, há uma redução na severidade e na probabilidade de morte. 
Com base neste entendimento de diminuição de danos em colisões com pedestres e ciclistas, muitas cidades no mundo aplicaram iniciativas de acalmamento de tráfego com a diminuição dos limites máximos de velocidade dos veículos automotores em seu perímetro urbano. Segundo o departamento de trânsito novaiorquino ${ }^{2}$, desde 2014, à exceção de vias expressas e arteriais principais, a cidade de Nova lorque (EUA) tem seu limite de velocidade máximo em $25 \mathrm{mph}$, aproximadamente, $40 \mathrm{~km} / \mathrm{h}$.

Não apenas para o sentido regulamentar, estas estratégias geram resultados eficazes no comportamento dos motoristas: na cidades Montreal (Canadá), que desde 2009 diminuiu seus limites de velocidade de $50 \mathrm{~km} / \mathrm{h}$ para $40 \mathrm{~km} / \mathrm{h}$ em vias locais e a cidade de Boston (EUA), que fez a mesma diminuição em 2017, houve reduções efetivas nas velocidades praticadas pelos veículos (HEYDARI et al., 2014; HU e CICCHINO, 2018).

Desta forma, mais do que criar infraestrutura cicloviária, é necessário considerar as externalidades que podem interferir o percurso do ciclista. Sobretudo para as ciclofaixas, que dividem o leito carroçável com os automóveis (separados apenas por tachas ou tachões), é importante considerar políticas de diminuição de velocidades para os veículos automotores a fim de aumentar a segurança dos ciclistas.

O cuidado na elaboração de projetos geométricos de vias cicláveis também deve levar em consideração a declividade para a implementação da via de forma adequada, dado que as rampas muito íngremes podem dificultar e até impedir o tráfego de bicicletas no sentido ascendente.

Segundo Callil (2018), a relação entre o uso da bicicleta e a topografia das cidades é um tema pouco explorado. Apesar de o relevo acidentado de uma cidade ser intuitivamente negativo para o ciclismo, ainda não existe uma bibliografia robusta que investigue a real dimensão da dificuldade que ele apresenta para a promoção do uso da bicicleta como meio de transporte.

Não obstante, há muitos parâmetros descritos em manuais e trabalhos acadêmicos acerca dos valores de declividade de maior preferência ou limitantes para os ciclistas.

2 DOT. New York City Speed Limit. Sítio web do Departamento de Trânsito de Nova lorque. Disponível em < https://www1.nyc.gov/html/dot/html/motorist/motorist.shtml>. Acesso em: 27 ago. 2019. 
O manual canadense de planejamento cicloviário de bicicletas públicas (TRANSPORT CANADA, 2010) indica que vias com declividades inferiores a $4 \%$ não afetam significativamente $\mathrm{O}$ uso da bicicleta, enquanto nas vias de declividades maiores que $8 \%$ são esperados pouco ou nenhum tráfego de bicicletas.

Já o manual estadunidense para planejamento cicloviário (AASHTO, 2012), menos restritivo, indica que, mesmo que as vias compartilhadas (no caso de São Paulo, ciclovias e ciclorrotas) sigam a declividade imposta pela via adjacente, o limite de $5 \%$ de declividade deve ser seguido.

O trabalho de Koh e Wong (2013) contribui para este tema ao apresentar resultados na avaliação da escolha de rotas de ciclistas em Singapura. Em seus resultados, as vias planas ou com declividades médias e baixas (abaixo de $8 \%$ ) apresentaram maior preferência dentre os usuários na pesquisa efetuada.

O guia espanhol de implantação de sistemas públicos de bicicletas (IDAE, 2007) não desencoraja plenamente a instalação de infraestruturas cicloviárias em vias de declividades maiores que $8 \%$, mas sugere a oferta de uma frota de bicicletas elétricas para solucionar esta característica. Em se tratando dos parâmetros de muitas cidades em desenvolvimento, como São Paulo, considerar a ocorrência de bicicletas elétricas para lidar com altos declives, pode não ser um critério abrangente a ser considerado, haja vista seus custos mais elevados na compra e a necessidade de combustível.

Contudo, também existe a compreensão de que ciclistas preferem trechos mais curtos, porém mais declivosos, a trechos muito longos com declividades médias. Em outras palavras, transitar em declividades altas por poucos metros se torna aceitável em comparação a trechos muito longos em relevos mais suaves (MILAKIS e ATHANASOPOULOS, 2014).

O manual de planejamento cicloviário brasileiro de referência (GEIPOT, 2001) também inclui as distâncias a serem percorridas em determinada declividade. A figura 2 apresenta um gráfico com rampas normais e rampas máximas admissíveis em função do desnível a ser vencido.

No gráfico é possível verificar a relação inversa entre as declividades e as distâncias: quanto maior a declividade, menor deve ser o percurso a ser percorrido. Como exemplo, do gráfico é possível extrair que uma declividade de $5 \%$ deve ser superada por no máximo $2 \mathrm{~m}$ em uma rampa normal ou por no máximo $4 \mathrm{~m}$ em uma 
rampa máxima. Desta forma, rampas de altas declividades podem ser aceitas no planejamento cicloviário, mas devem representar pequena parte da malha viária.

Figura 2 - Gráfico com rampas normais e máximas em função do desnível

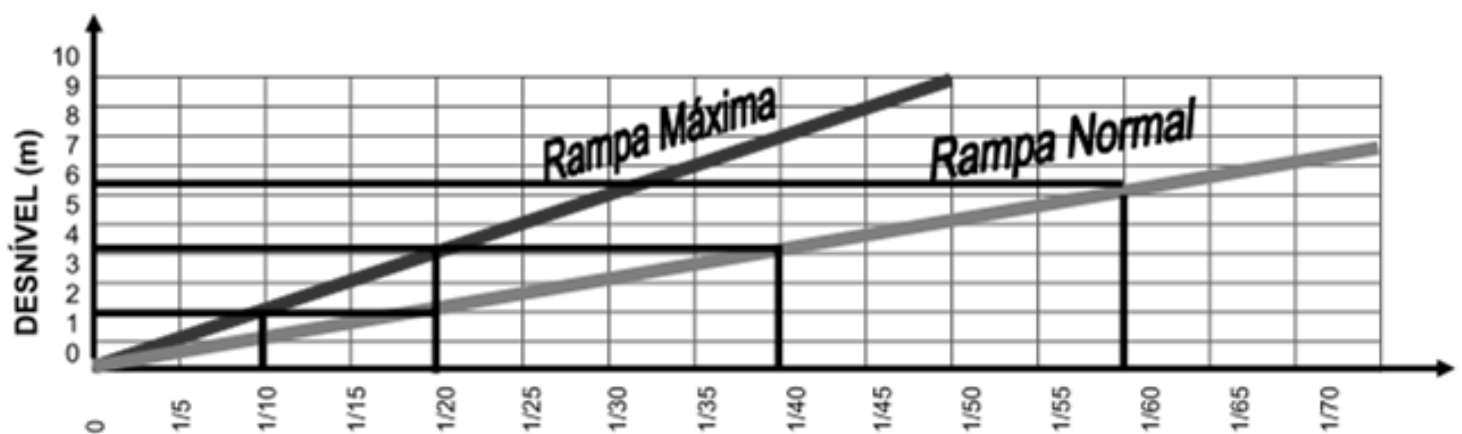

Fonte: Adaptado de GEIPOT, 2001

Muitos guias e manuais indicam as dificuldades em superar as subidas, mas 0 manual holandês de design para tráfego cicloviário (CROW, 2007) também alerta sobre os aspectos do trânsito da bicicleta nas descidas. No sentido descendente deve-se haver atenção, haja vista que sem a dificuldade em superar a gravidade, o ciclista pode atingir velocidades elevadas (35 a $40 \mathrm{~km} / \mathrm{h}$ ), aumentando o risco de acidentes. Desta forma, é recomendável que os padrões ideais de vias cicláveis não incorporem vias de declividades altas, mesmo com um sentido obrigatório descendente para o ciclista transitar.

As larguras das vias são um dos elementos que também carecem de atenção para a segurança cicloviária. Diferentemente de automóveis, a operação da bicicleta exige um espaço de manobra e circulação que não se limita à largura dos pneus, mas também considera a largura do guidão, do condutor e do movimento sinuoso necessário para a circulação.

Este movimento se relaciona diretamente com as habilidades do ciclista, mas principalmente, com a velocidade adotada: quanto menor é a velocidade da bicicleta, menor também é sua estabilidade, necessitando de um maior espaço lateral (AASHTO, 2012; CROW, 2007).

Muito se discute sobre quais larguras mínimas são necessárias para garantir a circulação de bicicletas de forma segura. Sheresck e Lerner (2015) relacionam a velocidade operacional e o volume de tráfego de veículos automotores em vias 
adjacentes como parâmetros para definir que tipo de infraestrutura cicloviária é necessária.

Como indicado na figura 3 , vias de baixos volumes de carros não necessitam de uma infraestrutura cicloviária específica. Contudo, em vias com alto volume de tráfego são necessárias ciclovias e ciclofaixas o que, em muitos casos, pode criar muitos conflitos com o espaço urbano já construído e consolidado.

Figura 3 - Velocidade e Volume de tráfego e Vias Cicláveis

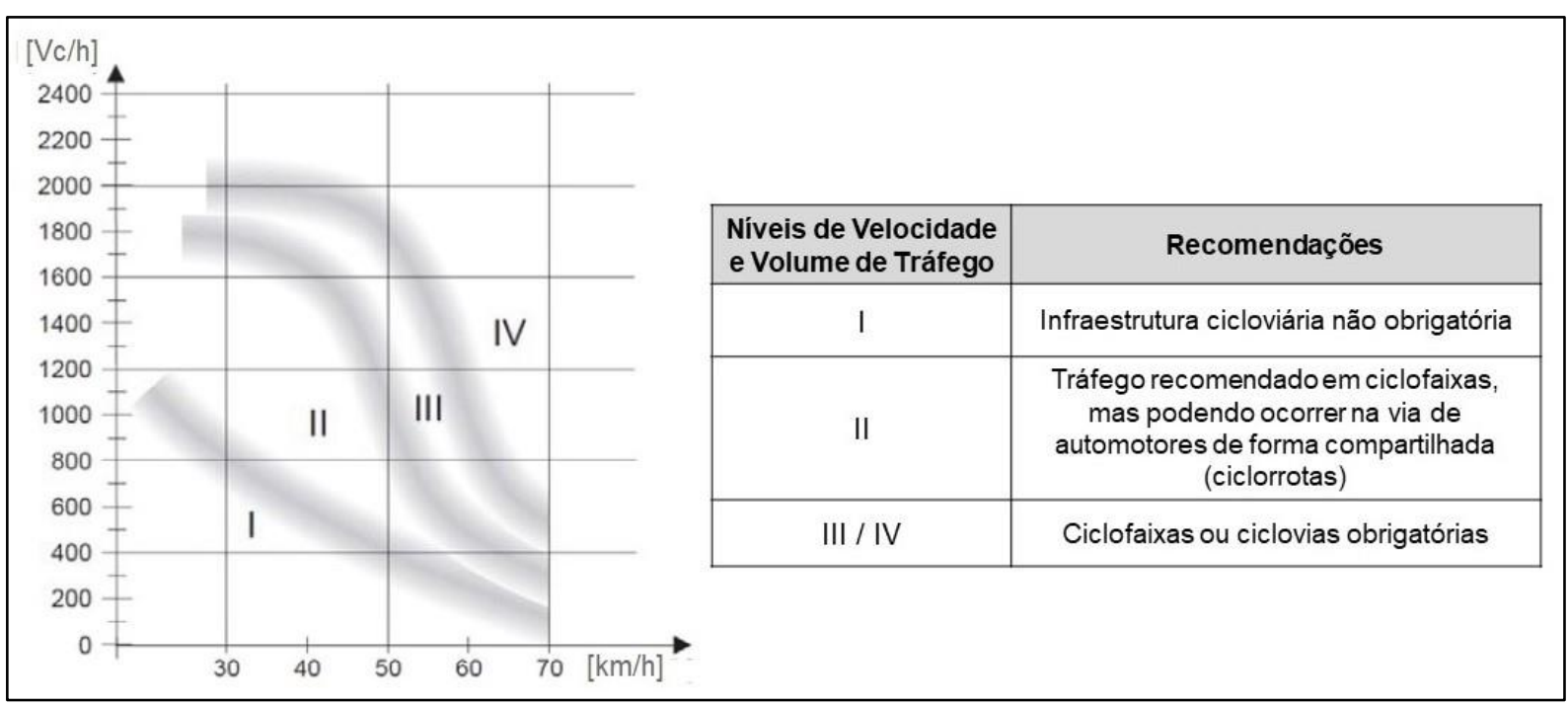

Fonte: Modificado de Sheresck e Lerner (2015)

No manual de planejamento cicloviário estadunidense (AASHTO, 2012) são indicadas larguras mínimas a depender do tipo de via ciclável: desde 1,2 m (em acostamentos disponíveis para o uso de bicicletas) a 1,8 $\mathrm{m}$ (em vias sem segregação por estacionamento). Já o manual holandês de design para tráfego cicloviário (CROW, 2007), de forma geral, indica larguras mínimas de 1,5 m, mas também as relaciona a depender do tipo de via ciclável (unidirecional, bidirecional etc.) conforme o volume de tráfego de bicicletas (variando de 2,0 m e 4,0 m).

A Companhia de Engenharia de Tráfego (CET), adaptando as indicações do manual de planejamento cicloviário brasileiro de referência (GEIPOT, 2001), também propõe larguras mínimas com base no tráfego de bicicletas em vias unidirecionais e bidirecionais, variando de 1,2 m a $4 \mathrm{~m}$ (quadro 3). 
Quadro 3 - Largura do espaço cicloviário conforme volume de bicicletas

\begin{tabular}{|c|c|c|}
\hline $\begin{array}{c}\text { Tráfego horário } \\
\text { (bicicletas por hora/sentido) }\end{array}$ & $\begin{array}{c}\text { Largura mínima útil } \\
\text { unidirecional }\end{array}$ & $\begin{array}{c}\text { Largura mínima útil } \\
\text { bidirecional }\end{array}$ \\
\hline até 1.000 & de $1,20 \mathrm{~m}$ a $1,50 \mathrm{~m}$ & de $2,25 \mathrm{~m}$ a $2,50 \mathrm{~m}$ \\
\hline de 1.000 a 2.5000 & de $1,50 \mathrm{~m}$ a $2,00 \mathrm{~m}$ & de $2,50 \mathrm{~m}$ a $3,00 \mathrm{~m}$ \\
\hline de 2.5000 a 5.000 & de $2,00 \mathrm{~m}$ a $3,00 \mathrm{~m}$ & de $3,00 \mathrm{~m}$ a $4,00 \mathrm{~m}$ \\
\hline mais de 5.000 & de $3,00 \mathrm{~m}$ a $4,00 \mathrm{~m}$ & de $4,00 \mathrm{~m}$ a $6,00 \mathrm{~m}$ \\
\hline
\end{tabular}

Fonte: CET, 2014

Lee et al. (2015) avaliaram com métodos de campo a largura ideal de ciclofaixas unidirecionais em relação as velocidades operacionais das bicicletas na Coreia do Sul. Para tanto, apresentaram os conceitos de "espaço essencial de manobra" e a "distância lateral de conforto", de modo que o primeiro delimita a área do movimento sinuoso básico da bicicleta e o segundo garante a segurança do ciclista em relação a obstáculos lindeiros (tachões, sarjeta etc.) e a circulação de carros, sendo que a soma de ambos determina a largura total da ciclofaixa (figura 4).

Figura 4 - Larguras operacionais de vias cicláveis

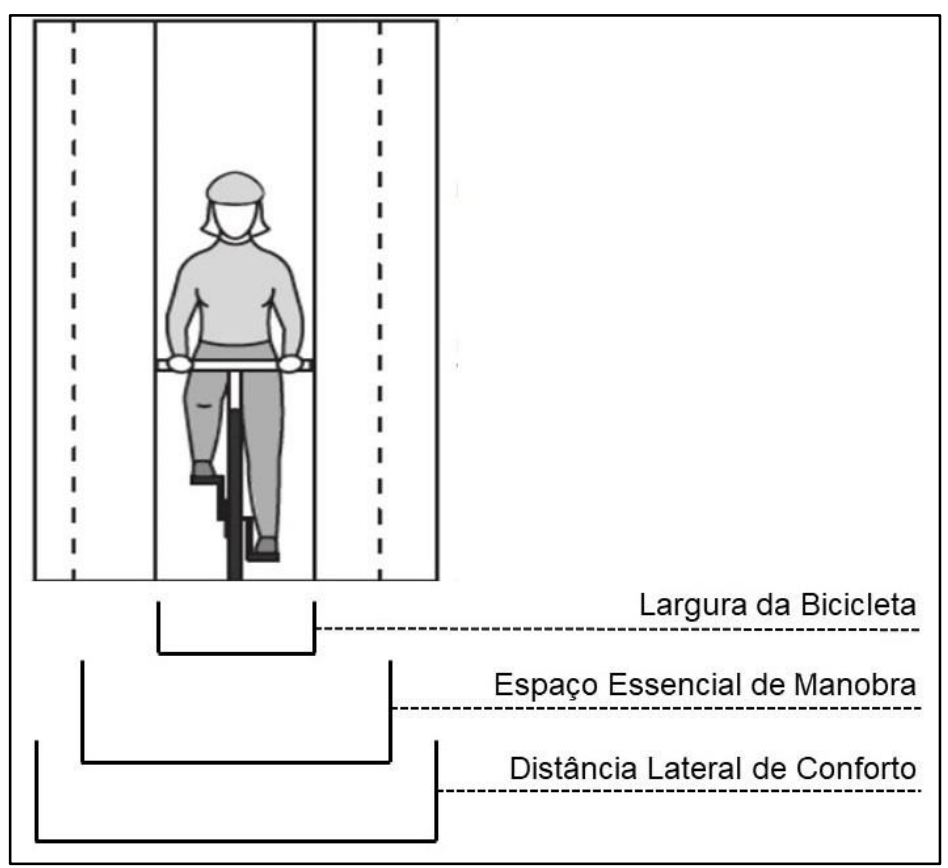

Fonte: Modificado de AASHTO, 2012

Foram feitos experimentos com vias de três larguras diferentes $(1,10 \mathrm{~m}, 2 \mathrm{~m}$ e $3 \mathrm{~m})$ combinadas com três velocidades da bicicleta $(10 \mathrm{~km} / \mathrm{h}, 20 \mathrm{~km} / \mathrm{h}$ e $30 \mathrm{~km} / \mathrm{h})$ e 
extraídas as larguras utilizadas de espaço essencial de manobra de cada ciclista nestes cenários. Seus resultados apontaram que a largura de $2 \mathrm{~m}$ se mostrou mais adequada dado que nas observações em vias de 1,10 m houve muitas extrapolações do espaço nas três velocidades (utilização média do espaço de 1,29 $\mathrm{m})$. Nos resultados para a largura de $3 \mathrm{~m}$ houve um pequeno aumento de espaço essencial de manobra necessário, mas não excedeu 2 m de largura.

Os autores também apontam que é importante considerar que muitos manuais indicam a largura mínima de 1,2 m para ciclofaixas (por exemplo, CET, 2014), o que se conflita com os resultados do trabalho citado. Entretanto, as médias das observações nas três velocidades foi inferior a 1,2 m, o que indica que esta largura pode ser utilizada como limite mínimo em áreas urbanas já consolidadas, mas não exatamente adequado para garantir a segurança cicloviária.

\subsection{SISTEMAS DE GERÊNCIA DE PAVIMENTOS E REDE CICLOVIÁRIA}

Um dos grandes desafios dos administradores públicos é a gestão de sua rede de transportes: "qual a situação da rede viária?", "quais as características de seus materiais, quando e quais técnicas de manutenção devem ser aplicadas?", "qual o custo desta manutenção?" são questões que não são respondidas facilmente. Para tanto, os Sistemas de Gerência de Pavimentos (SGP) são uma ferramenta capaz de coletar, gerenciar e analisar as condições da rede viária de forma a subsidiar tomadas de decisões sobre inspeção, manutenção e reabilitação, controle de tráfego, e respostas emergenciais (FERREIRA et al., 2009; PARIDA et al., 2005).

Os SGPs podem ser sintetizados como um grupo de processos coordenados que objetivam determinar a qualidade atual e futura da pavimentação para fins de manutenção e melhoria da infraestrutura com base em ferramentas de planejamento, projeto, construção, manutenção, avaliação, pesquisa e otimização orçamentária e econômica (HAAS e HUDSON, 1978; OECD, 1995). Em outras palavras, um SGP é capaz de subsidiar o gestor a decidir quando e quais vias devem passar por manutenção ou reabilitação, com qual prioridade e a que custo.

Os principais benefícios da adoção destes sistemas no planejamento de transportes se centram na otimização da tomada de decisão dos gestores com relação à manutenção ou a melhorias na rede, haja vista que a probabilidade de 
acerto é muito maior quando todos os fatores relacionados são considerados de forma integrada e sintetizada, o que também diminui a subjetividade e permite a justificativa pública das decisões (DNER, 1983).

Há duas abordagens possíveis para se hierarquizar as etapas e características internas a um SGP: os níveis de projeto e de rede. Solminihac-Tampier (2001), afirma que o nível de projeto envolve informações detalhadas das seções individuais ou de um pavimento em particular, com o propósito de determinar o momento que se deva realizar manutenção ou reabilitação. Já o nível de rede inclui fundamentalmente a observação de um conjunto de pavimentos de uma rede de transportes, com o objetivo de planejar decisões para grandes grupos de projetos a fim de otimizar a definição dos recursos. Por uma escolha metodológica, o presente trabalho aborda os seus resultados a partir da perspectiva do nível de rede.

Hudson et al. (1991) apresentam três subsistemas de um SGP e suas funções básicas para o nível de rede:

a) Subsistema de informação, que fornece dados de identificação, localização, dimensões geométricas, volumes de tráfego, históricos de acidentes das vias e dados da condição dos pavimentos (como a identificação dos defeitos, índices de irregularidade etc.);

b) Subsistema de análise, que apresenta estratégias de manutenção e reabilitação, identifica os insumos necessários e define os critérios de decisão, sob os limites das prioridades e dos orçamentos pré-definidos;

c) Subsistema de implementação, que deriva da aplicação dos critérios de prioridade definidos e limites orçamentários além de construir programas de longo prazo e garantir as informações para os orçamentos futuros.

A seguir, são apresentados trabalhos que exemplificam as funções, necessidades, análises e resultados possíveis com a implementação de SGPs em algumas cidades do Brasil e do mundo.

Emmert et al. (2010) aplicaram técnicas para o desenvolvimento de um SGP aplicado a estradas florestais para o transporte de madeira no município de Niquelândia (GO). Neste trabalho, foi criado um banco de dados georreferenciado do sistema viário que foi alimentado com uma hierarquização funcional (principais, secundárias e terciárias) e dados de qualidade dos pavimentos. A avaliação da situação das pistas de rolamento se deu por meio de vistoria de campo para a 
identificação de padrões construtivos, operacionais e defeitos. Estes dados foram enquadrados no Índice de Condição de Rodovia Não Pavimentada (ICRNP) com seis classes que variam de 0 (Péssima) a 100 (Excelente). A partir deste levantamento, foram feitas avaliações qualitativas e incorporaram-se indicações de intervenção e manutenção relacionadas aos defeitos de cada segmento e seus custos qualitativos associados.

Com estas informações organizadas no banco de dados geográfico, foi proposta uma priorização de intervenção. Foi dada maior prioridade à categoria funcional na seguinte ordem: vias principais, secundárias e terciárias. Posteriormente, foram propostas faixas ideais de ICRNP para cada categoria funcional (por exemplo, nas vias secundárias a faixa compreendia índice ideal entre 40 e 70); as vias com índice abaixo da faixa ganhavam prioridade, em seguida as vias dentro da faixa e, logo após, as vias com índice maior que a faixa proposta.

Como resultado destacável, chegou-se a um produto cartográfico que mostra a prioridade de manutenção de cada segmento de via e os custos qualitativos que estariam atrelados a esta manutenção.

No estudo de Li et al. (2013) foi avaliado o impacto das condições dos pavimentos de rodovias no total de acidentes de tráfego ocorridos entre 2008 e 2009 no Estado do Texas (EUA). Foram coletados dados dos acidentes com a seguinte organização: informações dos veículos envolvidos (tipo, modelo, ano etc.); informações das pessoas envolvidas (gênero, idade etc.); e informações do acidente (localização, hora, número de veículos, condições meteorológicas etc.). Dentre todas elas, foram selecionadas as seguintes variáveis: informação de uso comercial ou pessoal do veículo; condição da superfície do pavimento (molhado, seco, gelo, neve); grau de severidade do acidente (variando de 1 a 5); iluminação do local; número de veículos envolvidos; e mês em que o acidente ocorreu.

Do SGP do departamento de transporte do Texas (TxDot - Texas Department of Transportation) foram extraídas informações do período estudado. Como esta base de dados possui muitos elementos, o material coletado foi dividido em cinco variáveis numéricas: grau de defeito (distress score); grau de condição da via (condition score), baseado em entrevistas de usuários; grau de derrapagem (skid score), baseado nas condições que aumentam o risco de derrapagem; e dois índices 
de irregularidade do pavimento (IRI e Ride Score). Também foram incluídas informações sobre velocidade máxima permitida e tipo de material de cada pista. Por meio de ferramentas automatizadas de um Sistema de Informação Geográfica (SIG) estes dados foram sobrepostos espacialmente, indicando relações importantes para a gestão de segurança viária. Como exemplo, verificaram-se quais condições e características de pistas estavam estatisticamente relacionadas com a severidade dos acidentes. Um resultado que se destaca é o de que piores condições dos pavimentos não indicaram correlação estatística com acidentes graves, enquanto vias com melhores condições o indicam. Um possível entendimento apresentado é o de que vias com melhores características induzem o condutor a atingir maiores velocidades, o que aumenta o risco de acidentes.

Metodologias mais complexas para aprimorar estratégias de manutenção e reabilitação de vias com base em um SGP foram aplicadas no trabalho de Zhou et al. (2010). Os autores utilizaram ferramentas de mineração de dados em conjunto com SIG. Neste trabalho foram analisados os dados do sistema viário de uma área do estado da Carolina do Norte (EUA). A partir do sistema de gerenciamento construído pelo Instituto de Pesquisa e Educação em Transportes da Carolina do Norte (ITRE - Institute for Transportation Research and Education), foram levantados, identificados, quantificados e georreferenciados os defeitos de cada pista de rolamento por meio de trabalhos de campo e inspeção visual. Desta forma, a base de dados passou a ter cada segmento de via relacionado com a ocorrência e tipo de defeitos, dados de tráfego e dados econômicos (custos de implantação, custos totais etc.).

Com base na experiência dos investigadores do instituto, os autores utilizaram um índice que levou em consideração fatores como integridade estrutural, capacidade, rugosidade, resistência à derrapagem e grau de defeitos e o relacionou com sete estratégias de manutenção. O objetivo deste trabalho foi o de contrapor estas estratégias com os resultados da observação do que foi historicamente proposto pelos técnicos de campo. Para isso, foram utilizados algoritmos de mineração de dados que captaram associações entre índices de qualidade e estratégias de manutenção dentro do banco de dados do SGP.

A partir deste trabalho, conclui-se que os SGPs podem ser plataformas em que análises mais robustas sobre a qualidade da infraestrutura viária são 
desenvolvidas. Ademais, as ferramentas internas de um SGP podem agilizar e tornar a tomada de decisão sobre manutenção e reabilitação menos subjetiva e mais coesa.

Ferreira et al. (2009) apresentaram a implantação de um SGP em Oliveira do Hospital (Portugal). A partir de uma base de dados georreferenciados da rede viária com dados de tráfego, condições das vias, histórico de manutenção, entre outros, foi proposta a utilização de um índice de qualidade específico e uma ferramenta de decisão de manutenção oriunda de um modelo matemático que permite a definição de quais estratégias devem ser utilizadas para cada segmento de via, em um determinado período e com o objetivo de minimizar os custos de implantação destas manutenções. Dentre todas as características deste modelo, a que mais se destaca é a consideração da evolução do índice de qualidade ao longo do período estudado. Segundo os autores, a perspectiva destes modelos é mais ampla, pois consideram a transformação dos elementos de análise ao longo do tempo. Isto os aproxima de uma maior eficiência dos projetos de gerência de pavimentos de redes de transportes ao pensá-las de maneira dinâmica, não apenas como um recorte estático da realidade.

À exceção de Emmert et al (2010), que delimitou os segmentos de vias por meio de vetorização, os trabalhos apresentados se basearam em bancos de dados geográficos de fontes oficiais que forneceram uma quantidade significativa de informações, o que sugere a importância das agências de transporte desenvolverem e manterem bancos de dados de qualidade sobre sua rede viária.

As bases de dados levantadas nos trabalhos foram alimentadas com os defeitos e problemas nas pistas e suas características. Esta etapa também foi subsidiada por dados oficiais, como nos trabalhos de Li et al. (2013) e Zhou et al. (2010), que não apresentaram um método específico de identificação destes parâmetros em campo ou de forma indireta como os outros trabalhos. Ferreira et al. (2009) discutiram como os índices de classificação dos defeitos devem ser revistos e adaptados, mesmo que em pavimentos de mesmo material. As características do ambiente, do tráfego e principalmente dos modos afetam diretamente as curvas de deterioração e a evolução dos pavimentos do sistema viário. 
Para a definição dos critérios de priorização de manutenção e reabilitação, foram apresentadas saídas de complexidades muito diversas: mais simples, como no trabalho de Emmert et al. (2010), que definiu hierarquias dentro dos parâmetros de cada segmento ou método mais robustos, e mais complexos, como Ferreira et al. (2009), que analisou os índices de caracterização de defeitos e pavimentos de forma dinâmica além de correlacioná-los com metas de diminuição de custos financeiros.

A delimitação dos procedimentos de reabilitação e manutenção é uma etapa importante, pois contribui para a adoção dos métodos que subsidiarão a eficiência do sistema. A subjetividade é um elemento presente na definição de estratégias de manutenção de vias, pois nem sempre se apoia sobre os mesmos parâmetros e intensidades. Desta forma, Zhou et al. (2010) apresentou saídas para a homogeneização das combinações entre métodos de manutenção e defeitos dos pavimentos a partir de regras menos subjetivas, baseadas em análises estatísticas de regras e decisões.

Ademais, estes trabalhos mostram que os SGPs estão bastante interconectados com os SIGs: enquanto um organiza os conceitos e dados de entrada o outro contribui na análise espacial e disponibiliza de forma gráfica as informações que subsidiam tomadas de decisões sobre diversos temas ligados a conservação dos pavimentos de redes viárias.

O SIG é uma ferramenta que aprimora os SGPs pois, além de organizar e analisar as informações, ele fornece dados de suas localizações no espaço. Essa capacidade contribui enormemente para o gerenciamento de uma rede viária porque agiliza o fornecimento da informação (desde o status de um determinado segmento de via à técnica de manutenção que será aplicada) diminuindo o tempo da tomada de decisão com aumento da qualidade. Nessa união de ferramentas, o SIG funciona como o centralizador de todas as informações coletadas (características dos pavimentos, normas de qualidade, indicações de manutenção etc.), gerenciando os dados e indicando decisões exequíveis em relação a planejamento e ação em determinadas partes do sistema viário (PARIDA et al., 2005).

Por fazerem parte de um subsistema que possui relações com os outros modos de transporte, as vias cicláveis não são tratadas de forma independente e são incorporadas nos SGPs urbanos como parte da rede viária, considerando suas 
diferentes características em relação às ruas e avenidas. $O$ fato de os modos estarem integrados no sistema contribui enormemente para a tomada de decisão dos gestores da agência de transporte local, mas claramente demanda esforços e cuidados.

É importante destacar que, por mais que os modos possam compartilhar o mesmo espaço na rede, eles possuem especificidades que tornam mais complexos - agrupamento e a organização de informação a fim de diagnósticos claros e confiáveis. Um exemplo é a cidade de Davis (Califórnia, EUA), que considera as vias cicláveis em seu SGP, mas as diferencia das ruas e avenidas em todos os quesitos como índices de condição do pavimento, modelos de deterioração, projeções orçamentárias, dentre outros. (NCE, 2016).

Já a cidade de Bogotá (Colômbia), que recebeu a construção de uma ampla rede de vias cicláveis interconectadas de 1998 a 2003 (282 km implantados neste período), possui um sistema de gerência de pavimentos exclusivo para o sistema cicloviário (ARGUELLES et al., 2011; ROSIN, 2018).

Arguelles et al. (2011), descreveram a construção do sistema de gerência de pavimentos da rede cicloviária de Bogotá, apresentando um método baseado na análise de interconexões e importância funcional que, em seguida, são organizadas de acordo com as prioridades de suas características, materiais, modelos de deterioração, elementos de segurança e condições da infraestrutura.

Este sistema se organiza por meio de uma plataforma SIG com dados públicos disponibilizados na Web, possuindo um inventário georreferenciado dos elementos básicos das vias (pavimentos, plataformas, ciclovias etc.) e suas identificações. As vias cicláveis de Bogotá são hierarquizadas em primárias, secundárias, complementares e zonais. Ademais, são fornecidas informações geométricas e funcionais das vias, como as larguras e espaços livres ideais da seção transversal em relação ao número de usuários por dia ou uni ou bidirecionalidade, por exemplo. Para a classificação quanto à situação da qualidade das ciclovias adota-se o Índice de Condição de Ciclovias (ICC), que está em função do IRI e o Índice de Defeito (IF) que considera o tipo, gravidade, extensão, geometria dos defeitos e o tipo de pavimento. 
Para além dos diagnósticos, este SGP também propõe modelos de deterioração específicos para os pavimentos cicloviários, que consideram as especificidades do tráfego de bicicletas. Por exemplo, são consideradas como influências mais significativas as variações térmicas, o envelhecimento fotoquímico, o fissuramento pelas raízes das árvores plantadas, que a pressão e frequência de circulação de bicicletas.

Não é possível afirmar que haja um sistema tão robusto e amplamente divulgado como este para a rede cicloviária do município de São Paulo. Todavia, há iniciativas da sociedade civil que avaliaram sob vários aspectos a infraestrutura cicloviária paulistana e se aproximam das tarefas dos subsistemas de informação e análise de um SGP.

Em 2018, o Projeto Auditoria Cidadã, da Associação dos Ciclistas Urbanos de São Paulo (CICLOCIDADE), fez um levantamento in loco bastante robusto de todas as vias cicláveis paulistanas (na época, 484,8 km), por meio de vários parâmetros a fim de "chamar a atenção para as precárias condições que os ciclistas estão expostos pela falta de um programa de manutenção cicloviário" (CICLOCIDADE, 2018, p. 3).

Este relatório se baseou no Índice de Desenvolvimento da Estrutura Cicloviária (IDECiclo), que foi originalmente aplicado para a rede cicloviária de Recife pela Associação Metropolitana de Ciclistas do Recife (AMECICLO). Para a elaboração deste índice, foram analisados 24 parâmetros, dos quais os seguintes se destacam: de geometrias (larguras das vias, segregação entre os outros modos, intercessões, linearidade etc), de sinalização (semaforização, padrões visuais, cor dos pavimentos etc.), de qualidade de pavimentos (tipologia de revestimentos, defeitos e patologias) e de segurança viária. Estes resultados foram ponderados com base das tipologias das vias cicláveis e nas velocidades máximas das vias adjacentes de automotores.

Como a rede cicloviária de São Paulo é extensa, iniciativas de diagnósticos abrangentes como esta são custosas e complexas. Assim, sugere-se serem vinculados a sistemas de gerência de pavimentos, que são capazes de orçar e captar recursos financeiros mais facilmente, além de reunir significativa potencialidade técnico-científica. 


\section{REDE CICLOVIÁRIA DE SÃO PAULO}

Ao longo do desenvolvimento da cidade de São Paulo foram privilegiados os modos individuais motorizados: forte investimento em uma rede rodoviarista com a criação e alargamento de ruas, avenidas e vias expressas na história da cidade. Contudo, o recente processo de implantação de 400 quilômetros de vias cicláveis em São Paulo (o que torna hoje a capital paulista detentora do maior sistema cicloviário permanente da América Latina) vem consolidando mudanças não só em termos técnicos, mas em aspectos culturais, econômicos e políticos para a cidade (ITDP BRASIL, 2015; ROSIN, 2018).

Figura 5 - Totais de quilômetros de vias cicláveis construídas por gestão municipal

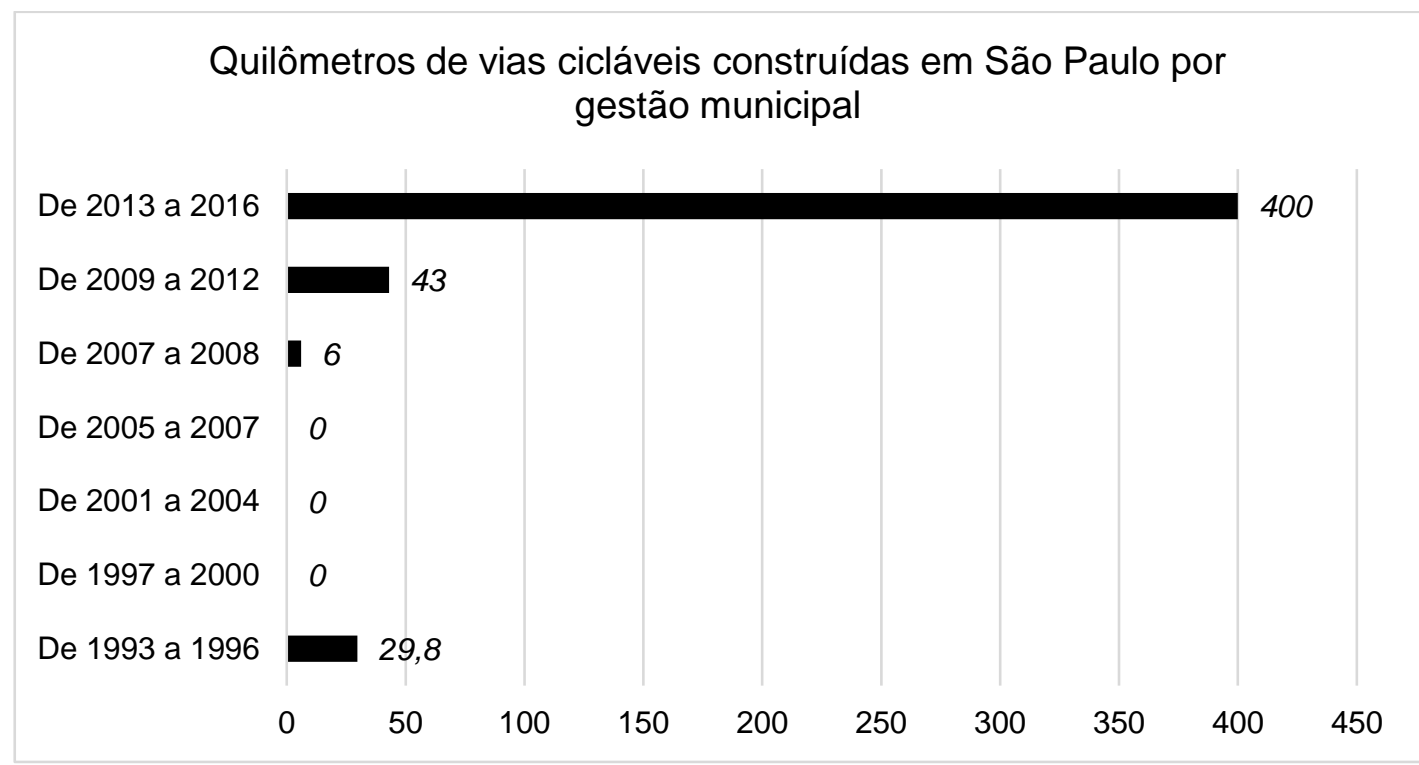

Fonte: Adaptado de ROSIN, 2018.

Segundo CET (2016), até o ano de 2012, houve a implementação de vários planos de construção de ciclovias em São Paulo atrelados a projetos de requalificação urbana, compensação ambiental, de transportes metroviários e ferroviários. Dentre estes, podemos citar projetos vinculados a operações urbanas (Água Espraiada, Nova Luz), a extensões de viário (Faria Lima), a construções de parques públicos (Parque Várzeas do Tietê), a novas linhas de metrô e trem (Extensões da Linha 2-Verde e da Linha 9-Esmeralda) etc. Contudo, estes projetos eram pulverizados e não integrados, o que gerou vias esparsas pela cidade, que não se conectavam. Isto as descaracterizava como sendo pertencentes a uma rede 
cicloviária propriamente dita. A partir deste cenário, de 2013 a 2016, foi definida a meta de implementação de $400 \mathrm{~km}$ de vias cicláveis, com a unificação destes vários planos de construção de ciclovias acumulados até então. A figura 5 mostra o grande salto na construção de vias cicláveis nesse período em São Paulo.

Atualmente, a rede cicloviária de São Paulo possui 503,6 km de vias, sendo 473,3 km de Ciclovias e Ciclofaixas e 30,3 km de Ciclorrotas ${ }^{3}$. A figura 6 apresenta o mapa da Rede Cicloviária de São Paulo.

Figura 6 - Mapa da Rede Cicloviária de São Paulo

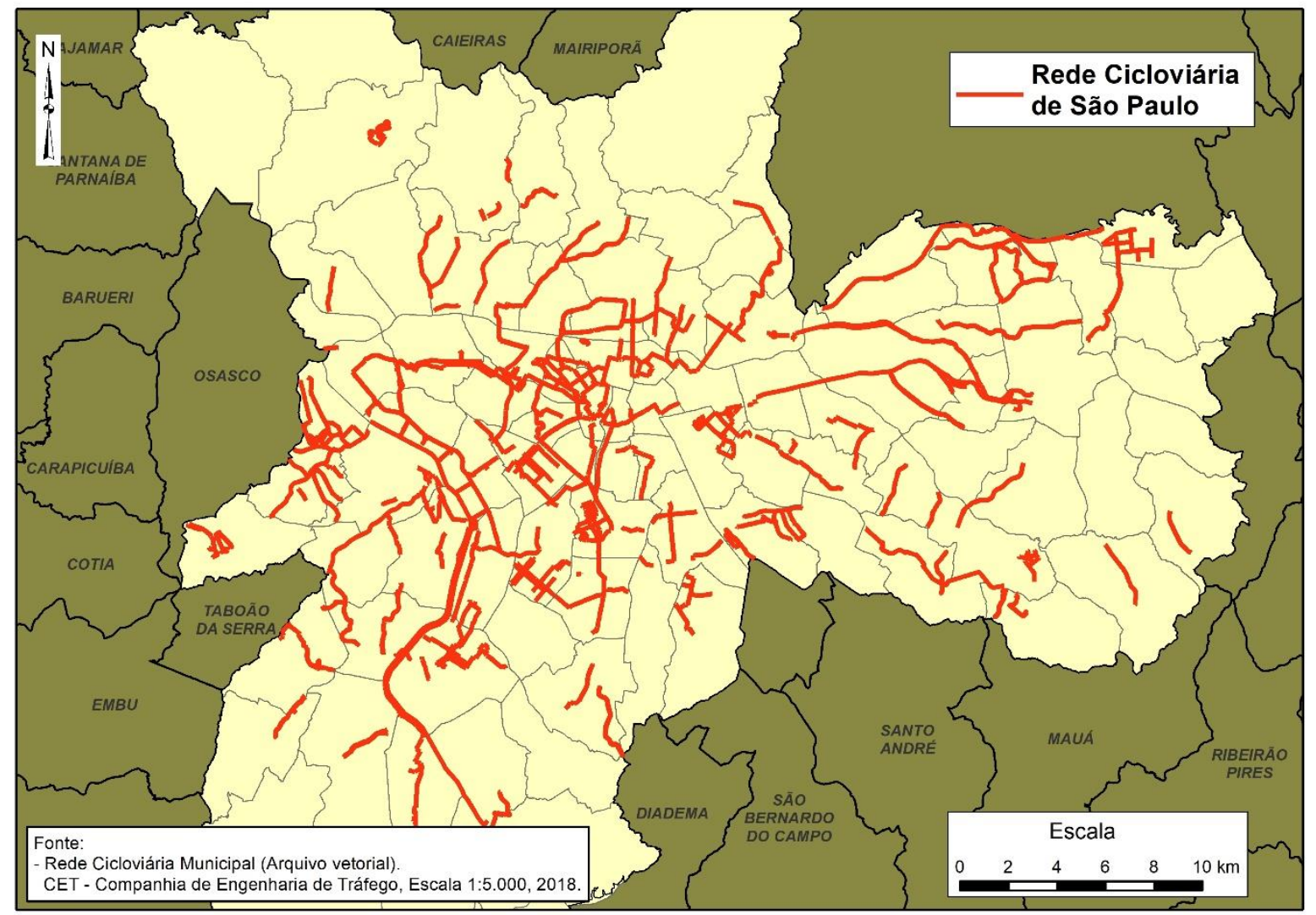

Fonte: Compilação e adaptação do autor ${ }^{4}$

Para além da infraestrutura pública, foram regulamentados os sistemas de compartilhamento de bicicletas (bike-sharing). Nos sistemas de compartilhamento, existem bicicletas alocadas em vários terminais distribuídos pela cidade em que um

\footnotetext{
${ }^{3}$ CET. Mapa de Infraestrutura Cicloviária. Disponível em <http://www.cetsp.com.br/consultas/bicicleta/ mapa-de-infraestrutura-cicloviaria.aspx>. Acesso em: 31 ago. 2019.

${ }^{4}$ Compilação dos vetores de vias cicláveis, distritos e municípios disponibilizados pela Prefeitura de São Paulo em março de 2018 por meio do sítio web <http://geosampa.prefeitura.sp.gov.br/PaginasPublicas/_SBC.aspx>.
} 
usuário pode tomar emprestada uma bicicleta e devolver em alguma estação próxima a seu local de destino. Várias cidades do mundo possuem tal sistema que subsidia a locomoção de cidadãos locais e a de turistas mediante algum tipo de cadastro a baixo ou nenhum custo. Estes sistemas, em geral, são compostos por quatro elementos principais: a) bicicletas customizadas (principalmente para evitar furtos e roubos); b) estações fixas e automatizadas para disponibilização das bicicletas; c) tecnologia de rastreamento para controle do uso da bicicleta; e d) sistema de informação em tempo real que fornece a localização e quantidade de bicicletas disponíveis em cada estação (DECASTRO, 2018).

Em São Paulo, foram implementados dois sistemas deste tipo: BikeSampa e CicloSampa. Também foram inseridos sistemas dockless de compartilhamento de bicicletas, em que não há uma estação física (Grin e Yellow). As bicicletas são carregadas com um sistema de GPS e ficam dispersas por uma área de atuação, sendo que cada retirada e entrega são gerenciadas por um aplicativo de smartphone.

Acerca do que se considera terminais no sistema cicloviário de São Paulo, estes apresentam características menos complexas, se comparados com outros modos como aeroviário ou ferroviário. Sua principal função (além da de estacionamento de bicicletas) é a de possibilitar uma integração intermodal na cidade. Basicamente existem os paraciclos e bicicletários (para as bicicletas privadas) e as estações de compartilhamento de bicicletas.

Os paraciclos possuem uma estrutura bastante simples e, em geral, são de uso público para estacionamento em praças e passeios urbanos. O usuário se responsabiliza integralmente pelos aparatos de segurança, como correntes e cadeados. Os bicicletários já apresentam estruturas mais robustas, incluindo zeladoria, e proteção a intempéries, além de demandar registro do usuário, o que aumenta o controle e proteção do veículo. Podem ser públicos ou privados, mas em geral, estão associados a algum terminal de outro modo (como estações de trem e metrô).

Vários projetos e manuais de planejamento cicloviário possuem uma diferenciação específica para cada tipo de via ciclável, que se baseiam de forma geral, nas características do seu nível de segregação, nas suas possibilidades de uso e compartilhamento com outros modos e seus volumes e velocidades 
considerados. Segundo CET (2014), existem três grupos de vias destinadas às bicicletas: ciclovias, ciclofaixas e vias compartilhadas.

As ciclovias possuem as características de maior segregação em relação aos outros modos e são construídas em níveis verticais diferentes, além de estarem associadas a gradis e alambrados (figura 7). Elas representam a situação de maior segurança para o ciclista, entretanto, necessitam de maior área livre entre o passeio e a via de automotores e maiores custos e tempo de implementação. Por mais que não seja uma norma oficial, as ciclovias em São Paulo, em sua maioria, são implementadas sobre pavimentos de concreto.

Figura 7 - Ciclovia da Avenida Paulista

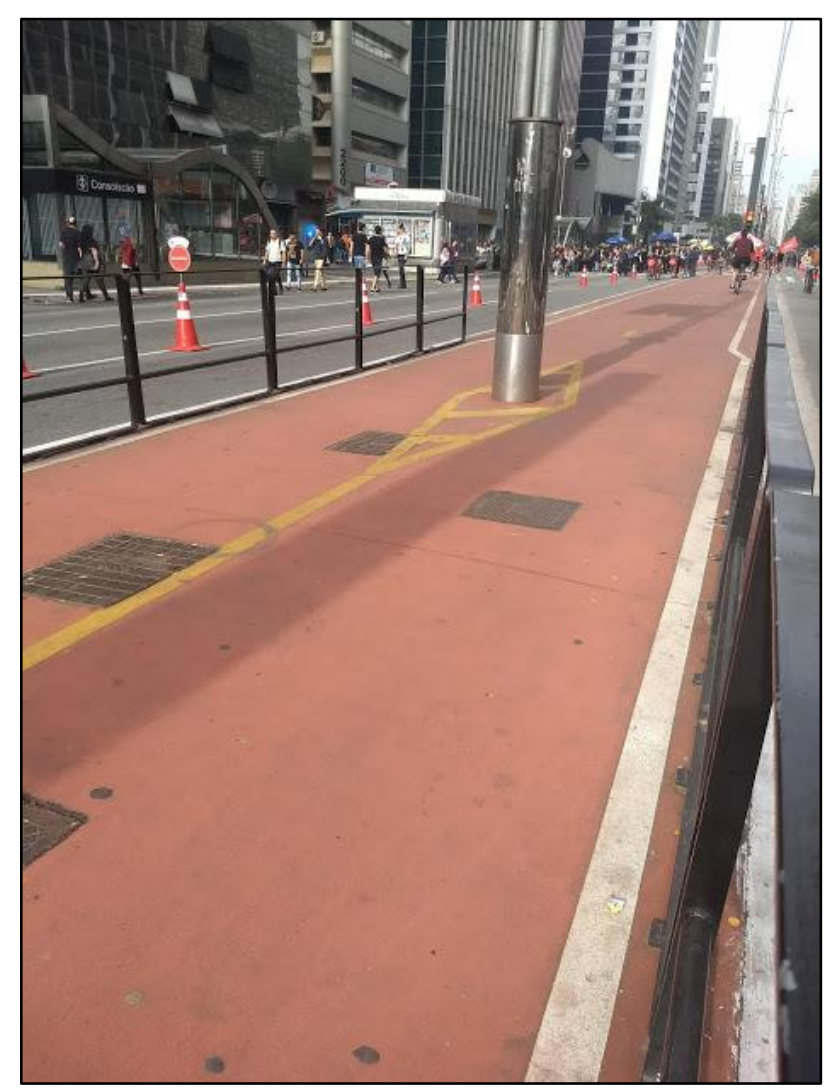

Fonte: o autor

Já as ciclofaixas (figura 8) fazem parte da própria pista de rolamento, mas são destinadas exclusivamente a locomoção de ciclos. Sua implementação ocorre por meio de sinalização vertical e horizontal, além de dispositivos auxiliares como tachões e cilindros delimitadores. Dessa forma, apresentam uma segregação menor em relação ao trânsito de carros se comparada às ciclovias, porém sua implementação é flexível e são construídas com menor tempo e custo. Ademais, são 
implementadas sem a modificação do tipo de pavimentação já instalada para a via de veículos automotores. Sendo assim, em sua maioria, ocorrem sobre pavimentos asfálticos.

Figura 8 - Ciclofaixa na Rua Artur de Azevedo

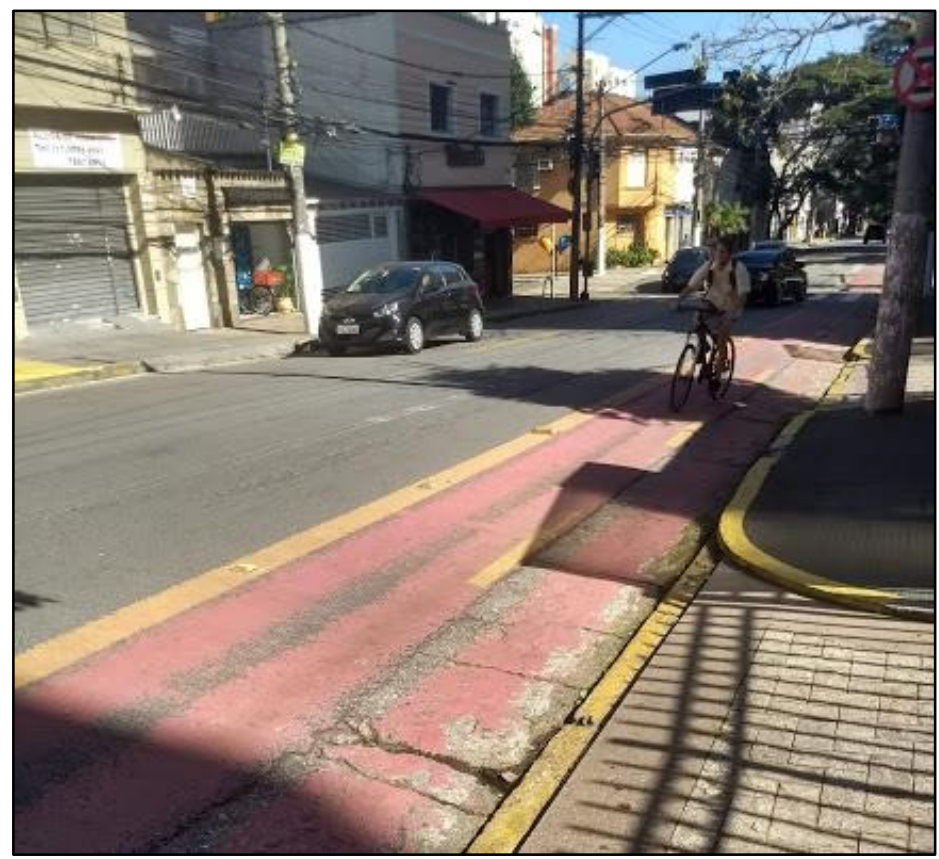

Fonte: o autor

Também existem as ciclofaixas operacionais, que são ativadas apenas em determinados horários e dias, em função de uma demanda específica. Como exemplo, existem as ciclofaixas de lazer em São Paulo, que são habilitadas com o auxílio de cones de trânsito e sinalização vertical. As vias compartilhadas são destinadas não exclusivamente a bicicletas, mas também a veículos automotores e pedestres. Na cidade de São Paulo existem as ciclorrotas, que são vias de menores velocidades operacionais com características mais seguras para a circulação ciclística (sua implementação ocorre por meio de sinalização vertical e horizontal).

Além das vias propriamente ditas, é de suma importância considerar o carregamento de bicicletas em outros modos. Por conta das suas características flexíveis, a bicicleta pode deixar de ser um veículo e se tornar uma carga que o usuário transporta consigo em trechos em que há maior dificuldade de locomoção (por conta da distância ou pela falta de infraestrutura cicloviária, por exemplo). Em São Paulo, a bicicleta pode ser transportada em espaços e horários determinados em transporte público (ônibus, metrô e trem) e em transporte motorizado individual (táxis com suporte para carregamento de bicicletas). 


\section{MATERIAIS E MÉTODOS}

Para alcançar os objetivos específicos e geral desta pesquisa, é proposta uma sequência de etapas apresentadas na figura 9 .

Figura 9 - Fluxograma de etapas

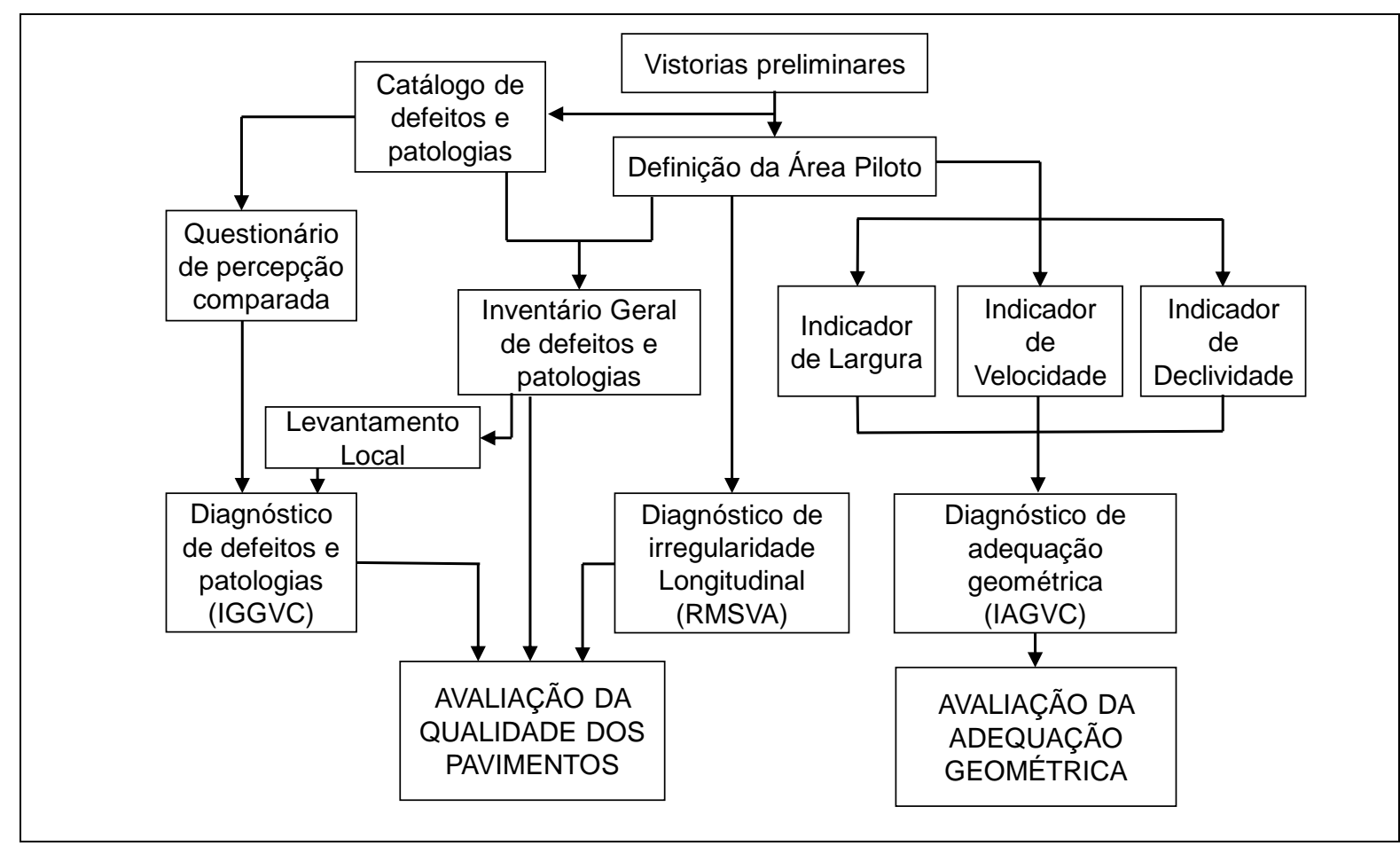

A partir de Vistorias preliminares, foi definida uma Área piloto dividida em segmentos de vias cicláveis, com base em critérios que a tornassem representativa de toda a rede cicloviária do município de São Paulo. Também foi produzido um Catálogo de defeitos e patologias que nortearam a sistematização dos dados coletados posteriormente.

Com base neste catálogo, foi feito um Inventário geral de defeitos e patologias que representasse a situação dos pavimentos de cada segmento de via ciclável da área piloto. Assim, foi possível definir uma subárea de análise para subsidiar avaliações comparáveis com outros métodos. Desta forma, foi proposta a aplicação de um Questionário de percepção comparada que resultou em fatores de ponderação que, vinculados a um Levantamento local, deu origem ao diagnóstico de defeitos e patologias, representado pelo Índice de gravidade global adaptado a vias cicláveis (IGGVC). 
Para complementar a Avaliação da qualidade dos pavimentos, foi proposto um indicador de irregularidade longitudinal baseado nas respostas de vibração de um sensor de aceleração vertical, representado pelo Root mean square vertical acceleration (RMSVA).

Para Avaliação da adequação geométrica das vias cicláveis da área piloto, foram estabelecidos três eixos principais: o Indicador de largura, o Indicador de velocidade de vias adjacentes e o Indicador de declividade. Estes três indicadores foram avaliados conjuntamente possibilitando o estabelecimento de um diagnóstico, representado pelo Indicador de adequação geométrica adaptado a vias cicláveis (IAGVC).

\subsection{Definição da área piloto}

Por conta da proposta de avaliação por meio de dados primários, o que representa um limitante para vistorias de campo em todas as vias cicláveis do município, foi definida uma área piloto (figura 10) que fosse representativa dentro de toda a rede cicloviária de São Paulo.

As vias selecionadas somam $26,56 \mathrm{~km}$ de extensão e, por mais que representem apenas 5,6 \% de toda a rede, foi definida com base em parâmetros que indicassem semelhanças com a rede ou que são significativamente utilizadas.

A área de estudo dá acesso a 20 equipamentos de transporte, dentre estações de metrô, trem, e terminais urbanos de ônibus. Isto pode indicar uma alta atração de ciclistas, dado que é possível transportar bicicletas na rede metroviária e ferroviária de São Paulo (em horários determinados) além da possibilidade de carregar bicicletas dobráveis em ônibus ou mantê-las em bicicletários (em geral, associados a estes equipamentos).

Este dado também é influenciado pelos sistemas de compartilhamento bikesharing de São Paulo. A área de estudo dá acesso a 45 estações (de 231 atualmente ativas) do BikeSampa, 11 estações (de 17 atualmente ativas) de CicloSampa e está dentro da área de atuação das redes Yellow e Grin de sistema dockless (em que não existem estações fixas) de empréstimo de bicicletas e patinetes elétricos. 
Figura 10 - Mapa da Área Piloto

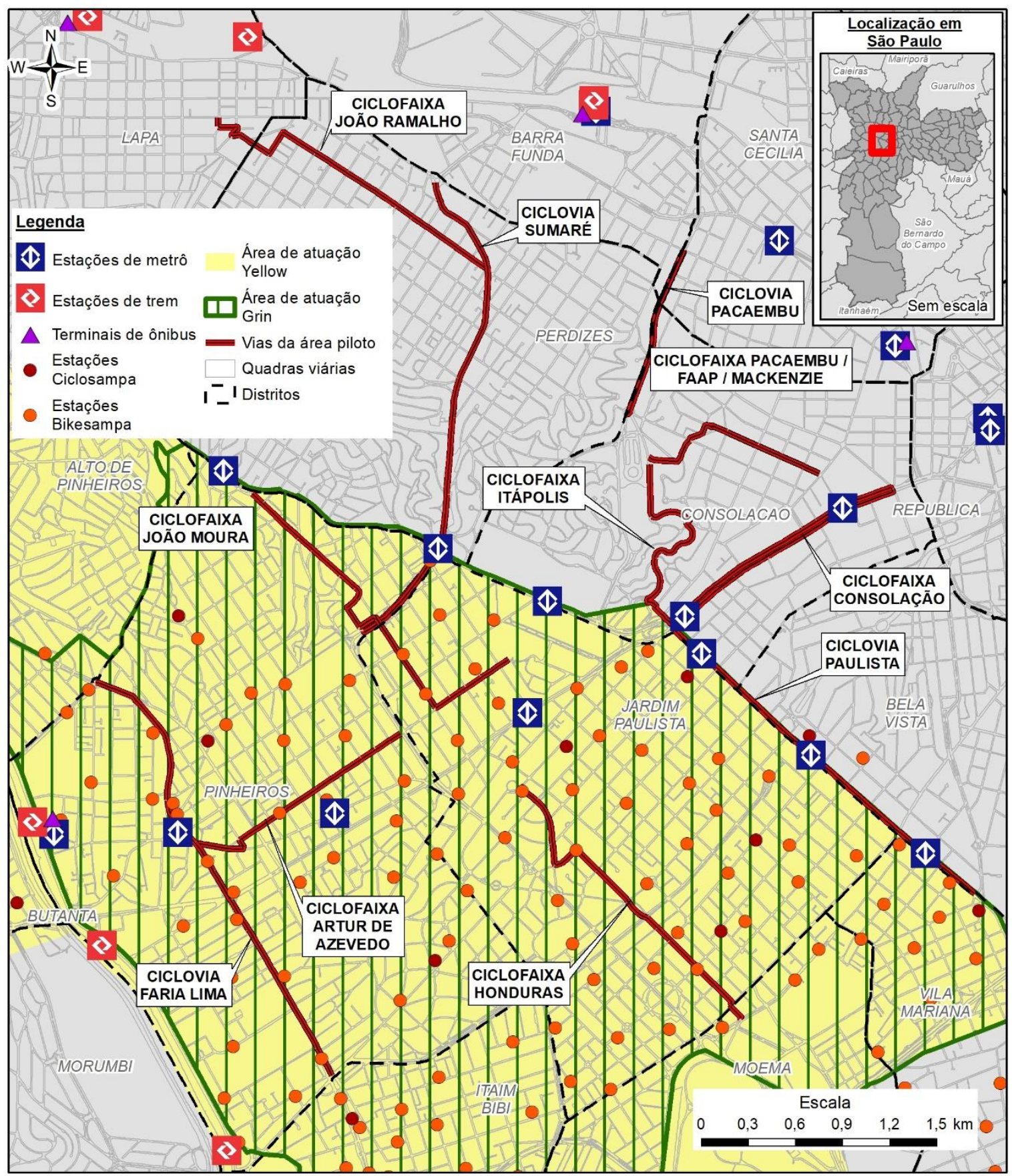

Fonte: Compilação e adaptação do autor ${ }^{5}$

Outro elemento importante são as características do relevo: São Paulo possui áreas bastante planas, devido às áreas de inundação de seus rios, mas também

\footnotetext{
${ }^{5}$ Compilação de vetores disponibilizados pela Prefeitura de São Paulo em maior de 2019 por meio do sítio <http://geosampa.prefeitura.sp.gov.br/PaginasPublicas/_SBC.aspx>. Áreas de atuação de Yellow e Grin disponibilizadas pelas próprias empresas por meio de seus respectivos aplicativos de celular.
} 
áreas de morros, que resultam em vias de médias e altas declividades. A área piloto contemplou estas características com exemplos de vias notadamente planas, como a ciclovia da Avenida Faria Lima (que é paralela ao Rio Pinheiros) e a ciclofaixa da Rua da Consolação, que liga a região do centro antigo de São Paulo (distrito da República) com o espigão da Avenida Paulista, no distrito do Jardim Paulista.

A área piloto também dá acesso a vários equipamentos de esporte, lazer e cultura, o que, além de atrair mais usuários para o sistema cicloviário, também favorece a inclusão de outros tipos de ciclistas (como crianças, idosos, esportistas etc.) com outros motivos de viagem (como lazer, turismo etc.). Na área piloto e seus arredores estão os Parques do Ibirapuera, do Povo, da Água Branca, Trianon, a Praça Roosevelt, as Ciclofaixas de lazer da Avenida Paulista e da Avenida Sumaré (faixas operacionais que funcionam apenas em domingos e feriados), o Esporte Clube Pinheiros, o Clube Hebraica, o Ginásio do Ibirapuera, as Unidades do Sesc Pinheiros, Paulista, Consolação, Pompeia, os museus e casas de cultura Masp, Itaú Cultural, Instituto Moreira Salles, Casa das Rosas, Japan House entre outros.

Para a melhor execução das análises e da organização dos dados coletados e produzidos, foi definida uma segmentação que se orientasse pelas intercessões ou por nós da rede. As vias cicloviárias foram divididas em unidades, aqui denominadas de segmentos, que respeitassem os limites das quadras adjacentes ou "quebras naturais", como curvas acentuadas. Em outras palavras, a unidade de observação é um segmento de via limitado por uma quadra viária, que recebeu uma nomenclatura única que informa o nome da via a que se relaciona, sua tipologia (ciclovia ou ciclofaixa) e número identificador.

Foram feitas vistorias preliminares para segmentação das vias e para checagem dos dados cicloviários disponibilizados pela Prefeitura de São Paulo. Em algumas vias havia obstáculos, estavam interditadas (figuras 11 e 12) ou estavam em localização diferente da informada. Nestes casos, os segmentos foram ajustados ou retirados da análise, resultando em 156 distribuídos em onze vias, sendo sete ciclofaixas e quatro ciclovias. 


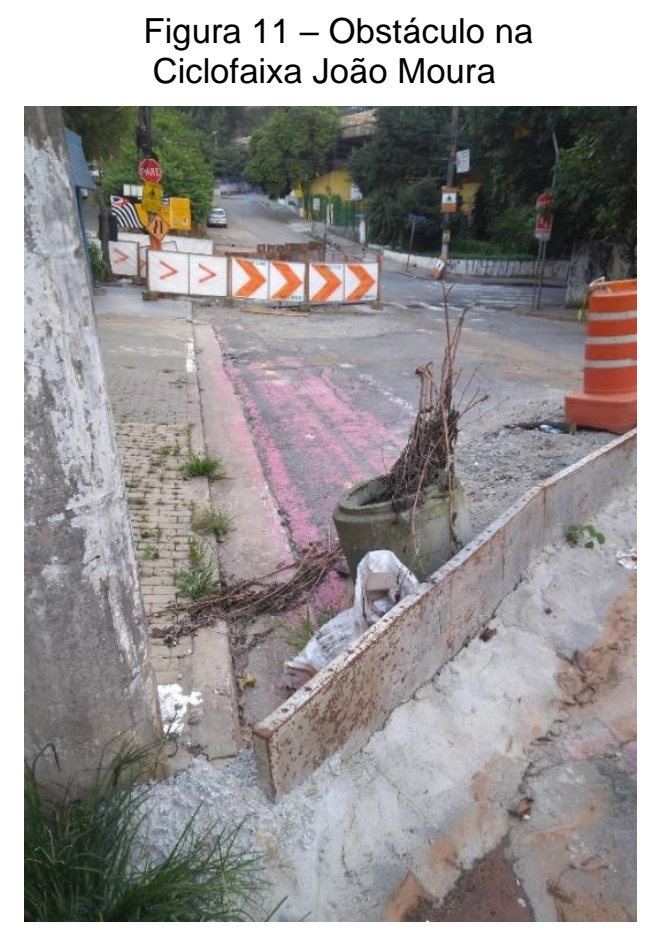

Figura 12 - Obstáculo na Ciclofaixa Itápolis

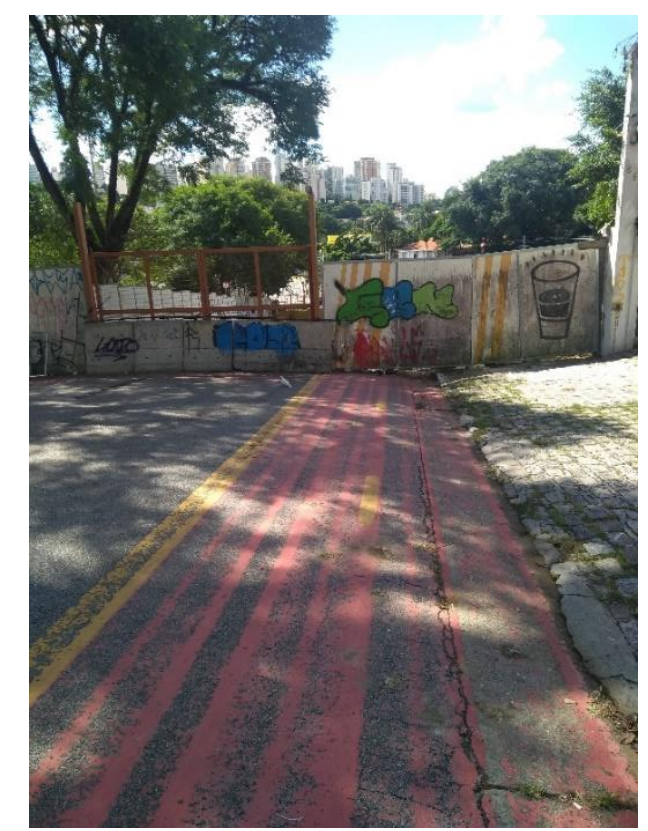

Fonte: o autor

quadro 4 mostra as vias cicláveis definidas para a área piloto e suas extensões após os ajustes supracitados, enquanto as figuras ${ }^{6} 13$ a 23 apresentam a localização de cada segmento de via ciclável em detalhe.

Quadro 4 - Vias cicláveis da área piloto

\begin{tabular}{|l|c|c|c|c|c|}
\hline \multirow{2}{*}{ VIAS CICLÁVEIS } & \multirow{2}{*}{$\begin{array}{c}\text { Extensão } \\
\text { total } \mathbf{( k m )}\end{array}$} & $\begin{array}{c}\text { Total de } \\
\text { segmentos }\end{array}$ & $\begin{array}{c}\text { Extensão } \\
\text { média (m) }\end{array}$ & $\begin{array}{c}\text { Extensão } \\
\text { máxima (m) }\end{array}$ & $\begin{array}{c}\text { Extensão } \\
\text { Mínima (m) }\end{array}$ \\
\hline Ciclofaixa Artur de Azevedo & 1,60 & 14 & 114,22 & 201,04 & 65,89 \\
\hline Ciclofaixa Consolação & 3,33 & 14 & 237,91 & 461,59 & 105,41 \\
\hline Ciclofaixa Honduras & 2,29 & 15 & 152,65 & 281,25 & 82,28 \\
\hline Ciclofaixa Itápolis & 1,50 & 5 & 300,49 & 421,74 & 77,12 \\
\hline Ciclofaixa João Moura & 2,58 & 19 & 135,57 & 249,14 & 74,46 \\
\hline Ciclofaixa João Ramalho & 2,25 & 20 & 112,47 & 162,35 & 43,04 \\
\hline $\begin{array}{l}\text { Ciclofaixa Pacaembu / Faap / } \\
\text { Mackenzie }\end{array}$ & 1,29 & 8 & 161,59 & 219,04 & 92,77 \\
\hline Ciclovia Faria Lima & 3,05 & 18 & 169,26 & 293,79 & 93,52 \\
\hline Ciclovia Pacaembu & 2,24 & 6 & 373,14 & 400,93 & 354,35 \\
\hline Ciclovia Paulista & 2,70 & 18 & 149,97 & 253,49 & 78,87 \\
\hline Ciclovia Sumarén & 3,73 & 19 & 196,19 & 380,56 & 99,15 \\
\hline \multicolumn{1}{|c|}{ Área piloto } & 26,56 & 156 & 191,22 & 461,59 & 43,04 \\
\hline
\end{tabular}

6 Figuras produzidas com base na adaptação dos vetores de vias cicláveis e na representação dos vetores de distritos, vias e quadras viárias disponibilizados pela Prefeitura de São Paulo em maio de 2019 por meio do sítio <http://geosampa.prefeitura.sp.gov.br/PaginasPublicas/_SBC.aspx>. 
Figura 13 - Mapa situacional da Ciclofaixa Consolação

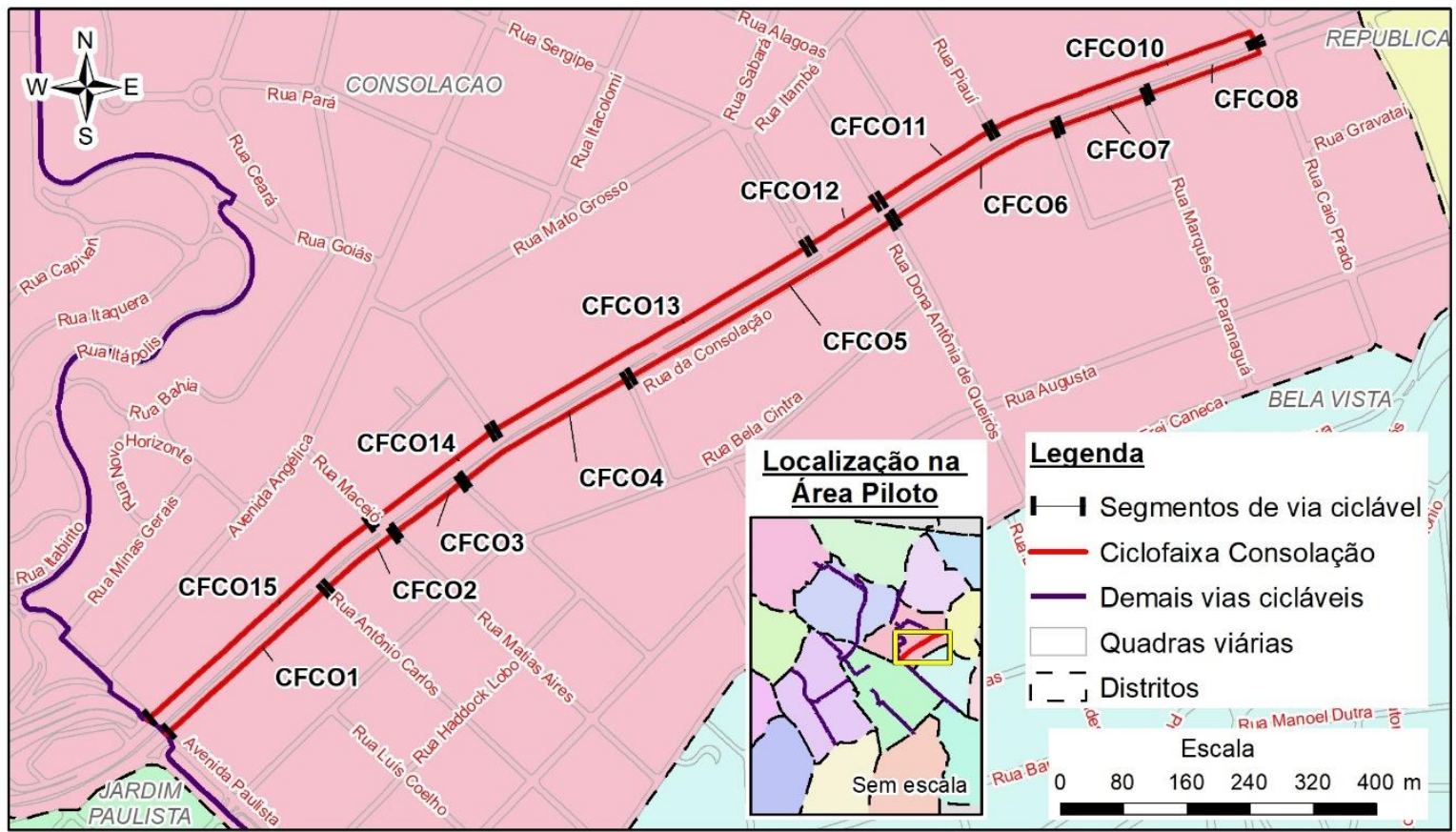

Figura 14 - Mapa situacional da Ciclofaixa Itápolis

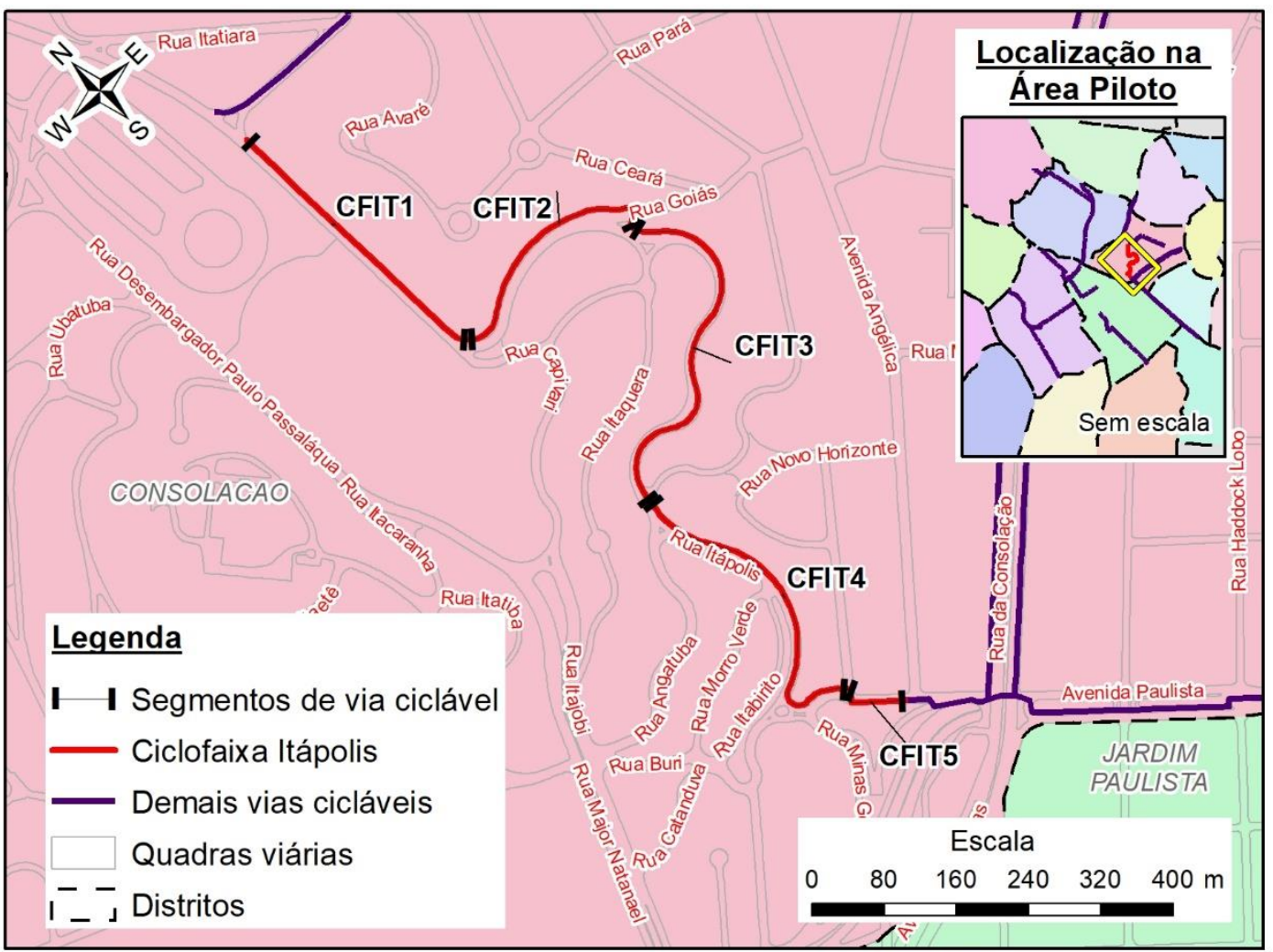


Figura 15 - Mapa situacional da Ciclofaixa João Moura

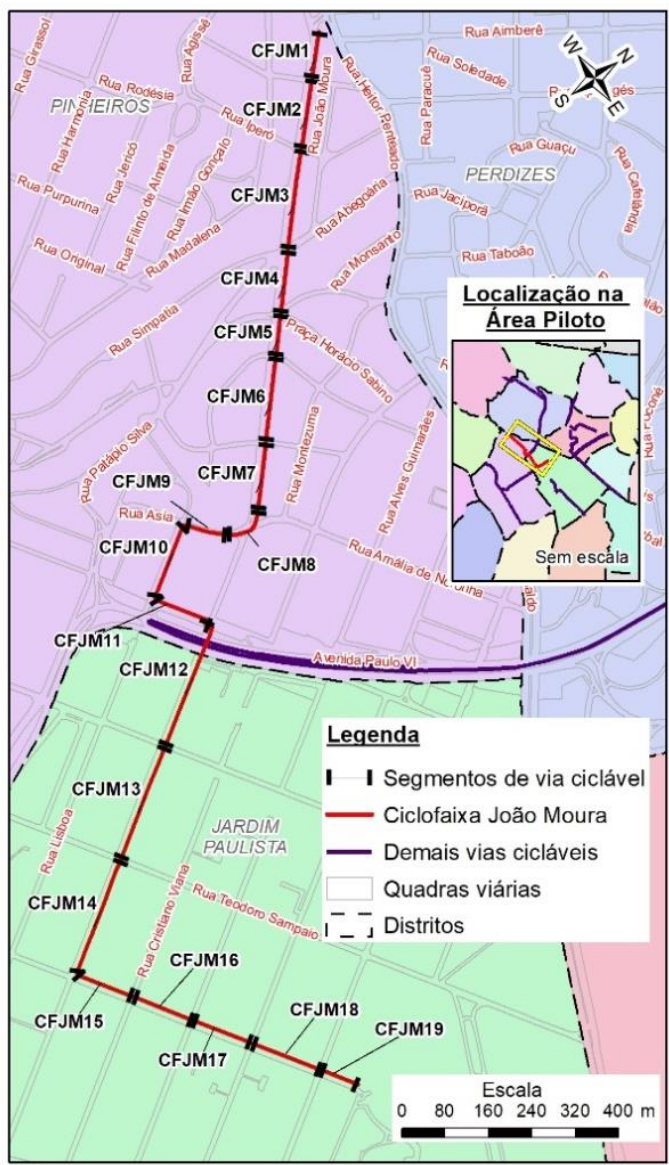

Figura 16 - Mapa situacional da Ciclofaixa Honduras

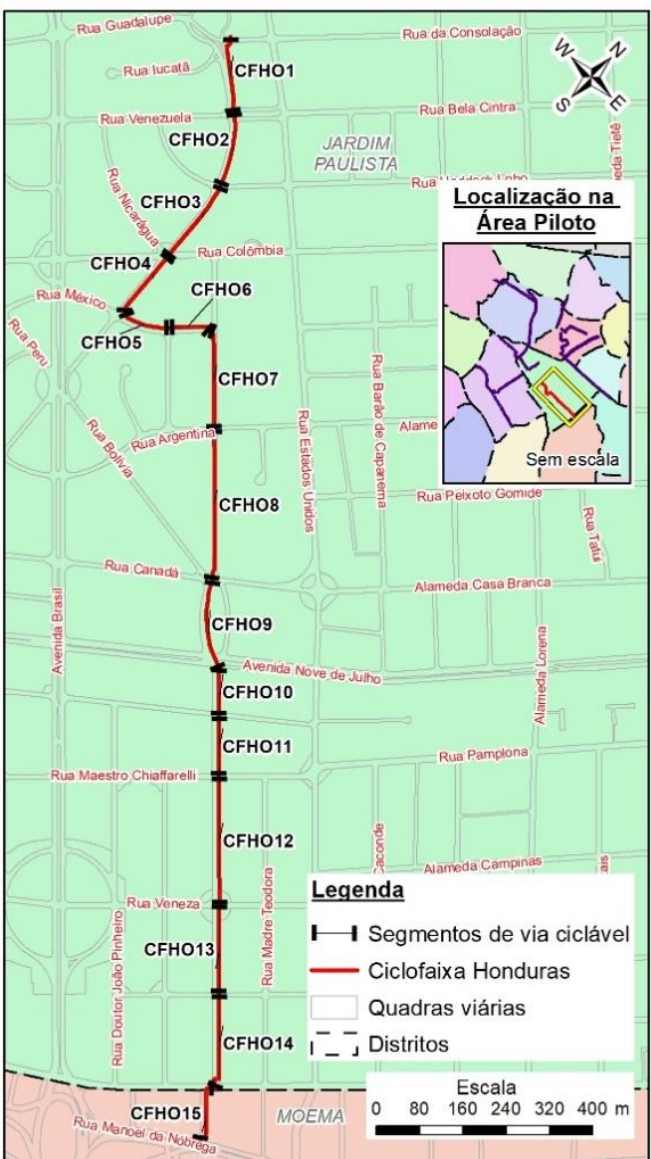

Figura 17 - Mapa situacional da Ciclofaixa Pacaembu / Faap / Pacaembu

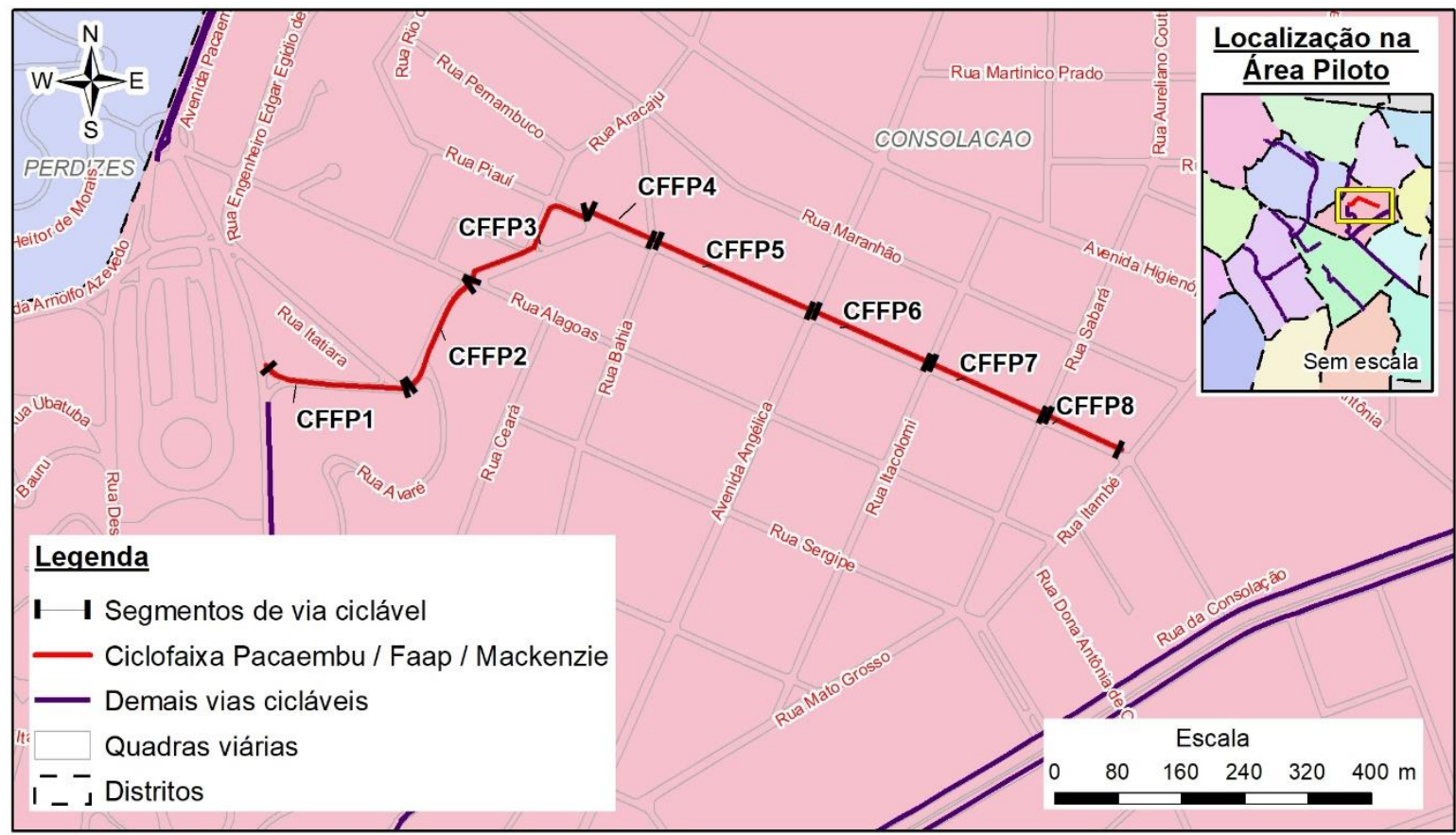


Figura 18 - Mapa situacional da Ciclovia Faria Lima

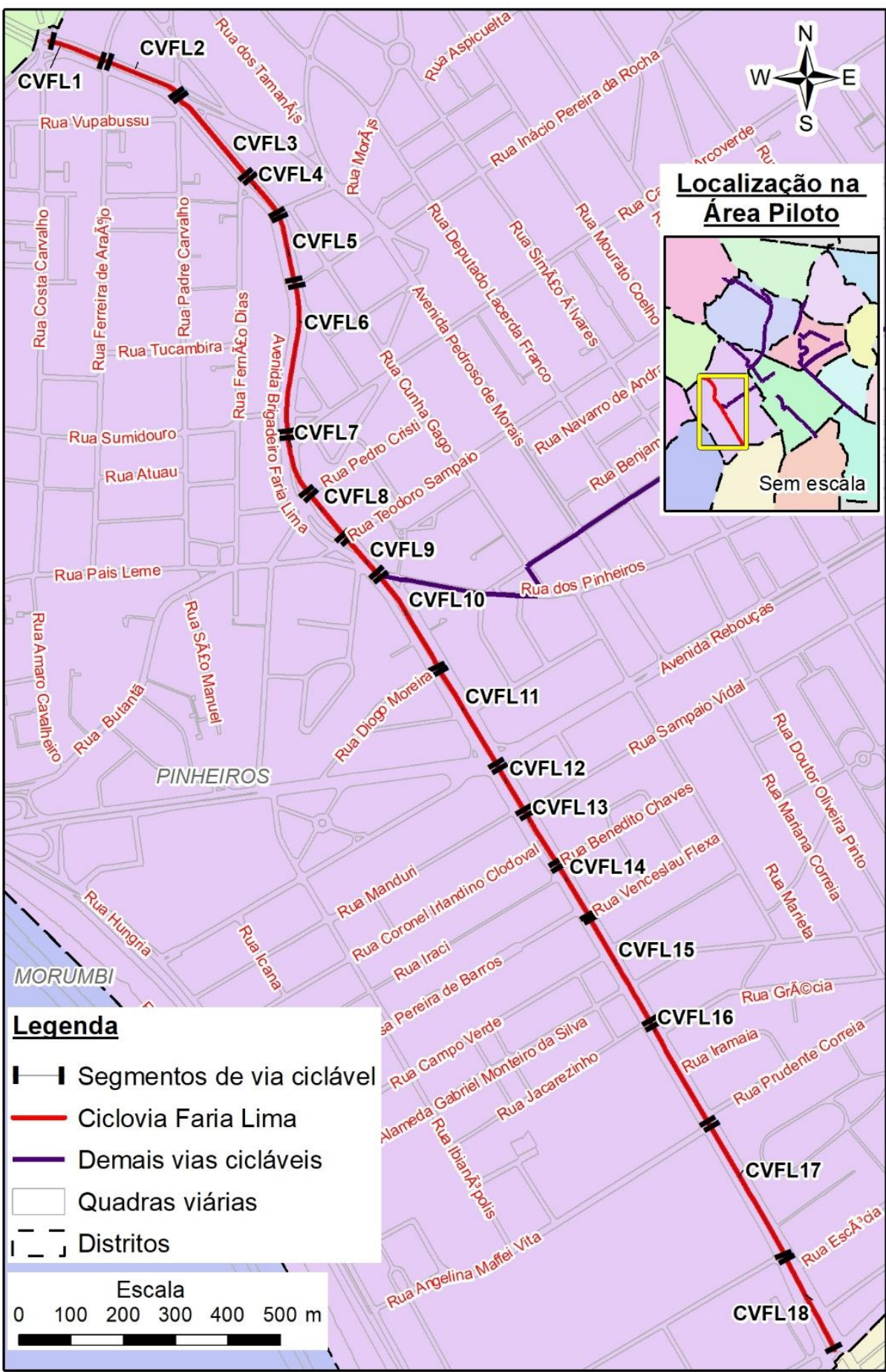


Figura 20 - Mapa situacional da Ciclofaixa Artur de Azevedo

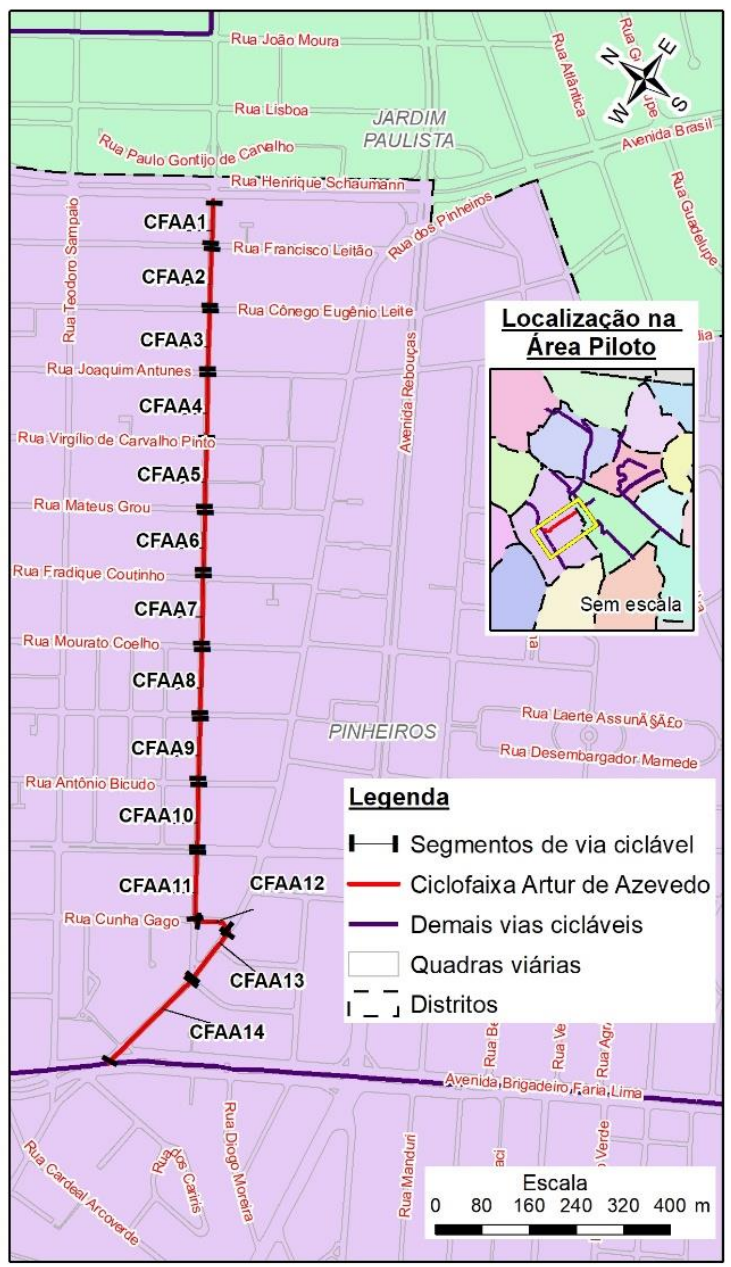

Figura 19 - Mapa situacional da Ciclofaixa João Ramalho

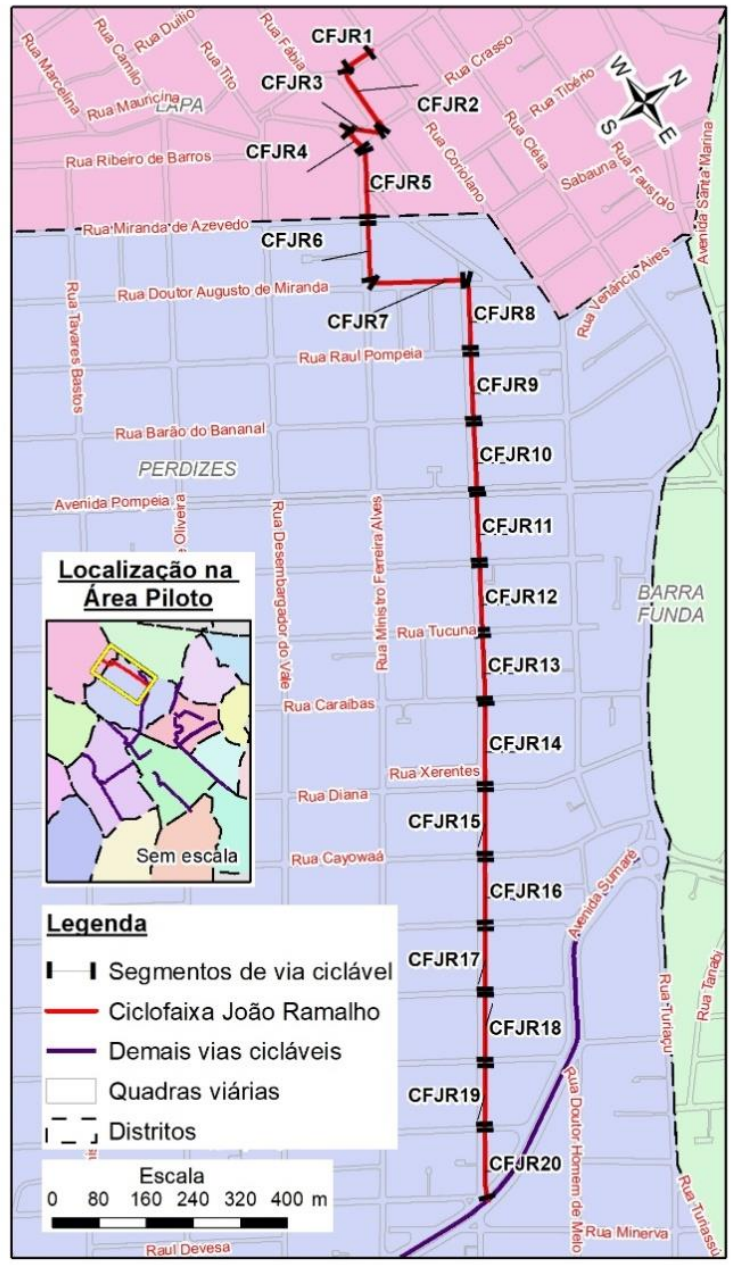

Figura 21 - Mapa situacional da Ciclovia Pacaembu

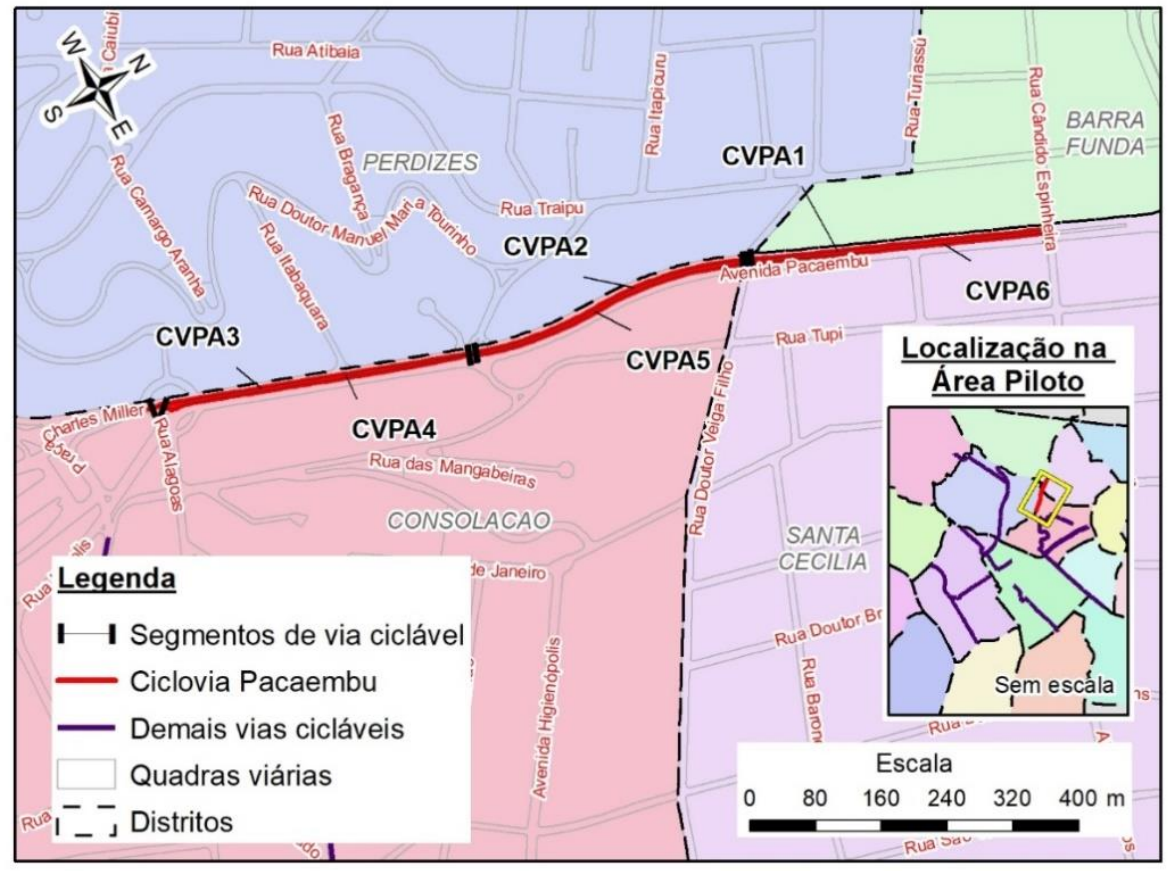


Figura 22 - Mapa situacional da Ciclovia Paulista

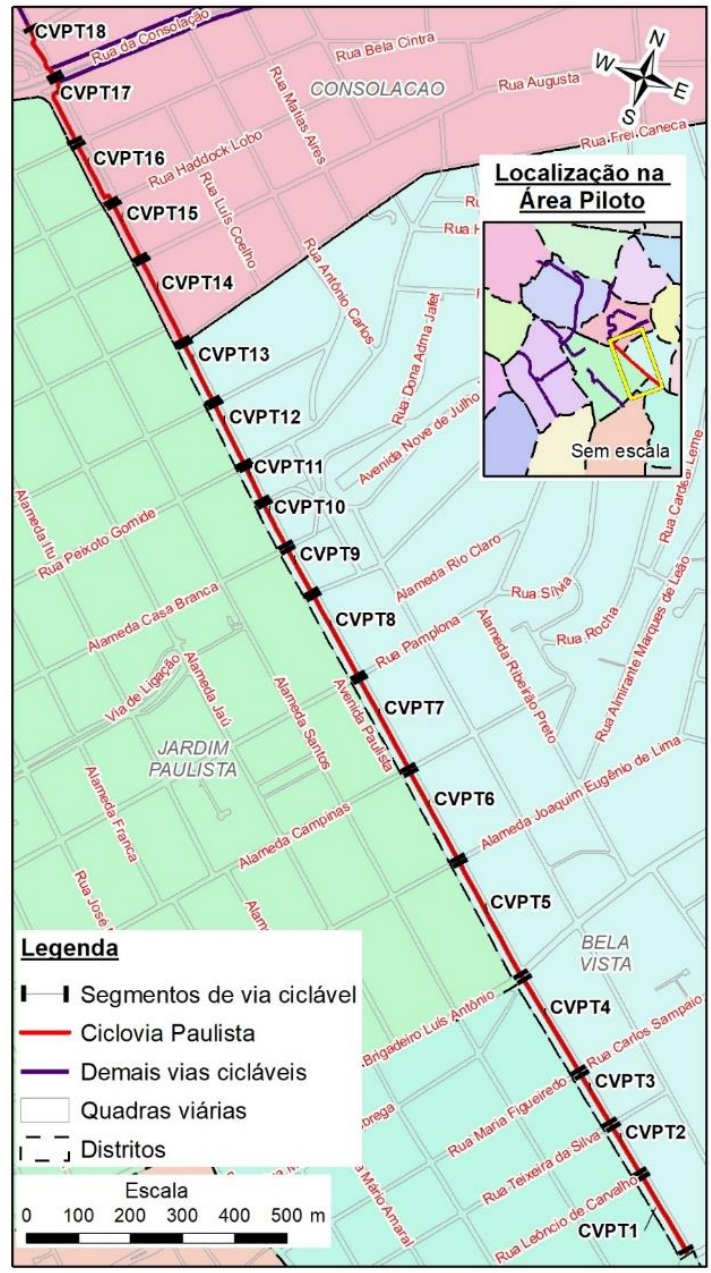

Figura 23 - Mapa situacional da Ciclovia Sumaré

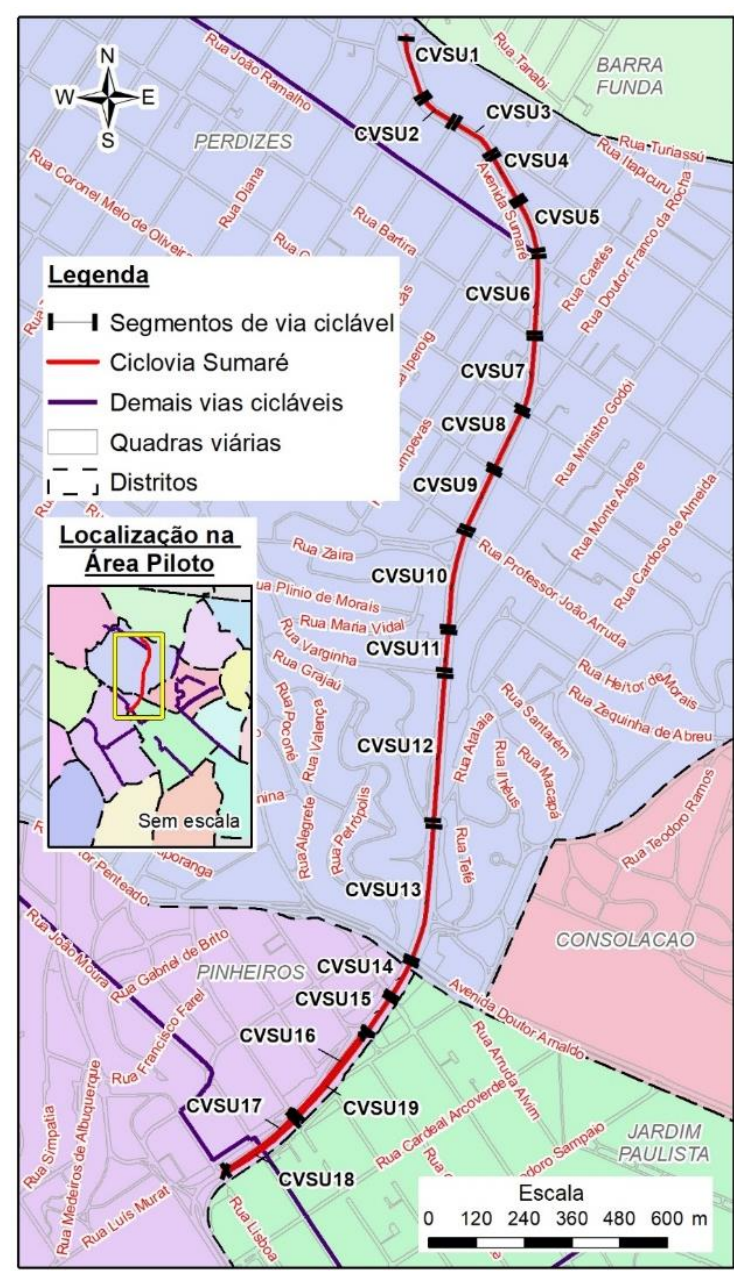

\section{2. $\quad$ Avaliação da qualidade dos pavimentos das vias cicláveis}

Para que fosse possível a avaliação quantitativa da condição dos pavimentos e da adequação geométrica das vias cicláveis de forma unificada, foram propostas coletas de dados em dois eixos:

1. Diagnóstico de defeitos e patologias, que definiu, quantificou e avaliou as vias cicláveis na perspectiva funcional de conforto e segurança.

2. Diagnóstico de irregularidade, que é representado por um indicador que avaliou as condições de irregularidade longitudinal e conforto dos ciclistas. 


\subsubsection{Diagnóstico de defeitos e patologias}

O diagnóstico de defeitos e patologias tem por objetivo a definição de quais problemas funcionais nos pavimentos afetam a percepção de conforto e segurança dos ciclistas, além da suas quantificação e avaliação para a área de estudo. Muitas normas e recomendações foram produzidas para a sistematização das principais patologias de pavimentos rodoviários, contudo ainda hoje faz-se necessária o desenvolvimento de pesquisas que adaptem as normas vigentes para vias cicláveis.

Além da contribuição para a identificação dos defeitos, para esta seção foi proposto um método de quantificação e posterior análise em nível de rede dos segmentos de vias cicláveis. Por meio dele é possível ter a dimensão dos defeitos mais frequentes ou do nível de deterioração de cada segmento de forma rápida e integrada a outros indicadores como os parâmetros de geometria.

\subsubsection{Catálogo de defeitos e patologias em vias cicláveis}

Para que os indicadores propostos e a avaliação de qualidade dos pavimentos fossem possíveis, foi necessária a elaboração de um catálogo de defeitos e patologias de vias cicláveis. Como não há uma diretriz brasileira oficial específica sobre este tema, o presente trabalho propõe uma adaptação das normas e manuais que descrevem as terminologias e as patologias em pavimentos rodoviários de concreto e asfálticos. Essa adaptação também teve como base as vistorias preliminares nas vias de São Paulo que indicaram os problemas e defeitos mais frequentes e que influenciam no conforto e na segurança dos ciclistas.

É importante ressaltar que esta análise teve como foco a experiência do ciclista e no que, de fato, compromete seu conforto e segurança e não apenas em fatores estruturais de gênese, por exemplo. Desta forma, os defeitos e patologias identificados puderam ser agrupados conforme sua tipologia de pavimentos em que ocorrem, como mostra o quadro 5. 
Quadro 5 - Defeitos e patologias de vias cicláveis

\begin{tabular}{|c|c|}
\hline Grupo & Tipo \\
\hline \multirow{5}{*}{$\begin{array}{l}\text { Pavimentos asfálticos e de } \\
\text { concreto }\end{array}$} & Fissuras Isoladas \\
\hline & Buracos \\
\hline & Desgaste da pintura superficial \\
\hline & Remendos \\
\hline & $\begin{array}{l}\text { Tampas de Poços de visita de aço } \\
\text { ou concreto (PV) ou Bocas de Lobo }\end{array}$ \\
\hline \multirow{8}{*}{ Pavimentos asfálticos } & Fissuras em Blocos \\
\hline & Afundamento \\
\hline & Escorregamento \\
\hline & $\begin{array}{l}\text { Grelha de sarjeta com espaçamento } \\
\text { longitudinal acentuado }\end{array}$ \\
\hline & Desnível entre via ciclável e Sarjeta \\
\hline & Sarjeta como parte da via ciclável \\
\hline & $\begin{array}{c}\text { Rampas de acesso de } \\
\text { estacionamento }\end{array}$ \\
\hline & Valetas nas intercessões \\
\hline \multirow{6}{*}{ Pavimentos de concreto } & Quebras \\
\hline & Esborcinamento de juntas \\
\hline & $\begin{array}{c}\text { Degrau ou Escalonamento nas } \\
\text { juntas }\end{array}$ \\
\hline & Abertura de Juntas \\
\hline & Juntas de Transição \\
\hline & Alçamento ou esmagamento \\
\hline
\end{tabular}

Os defeitos catalogados para vias cicláveis de pavimentos asfálticos, além das vistorias preliminares, tem como base a análise das classificações de pavimentos rodoviários de Balbo (1997), Bernucci et al. (2007) e DNIT (2003b), enquanto os defeitos de vias cicláveis de pavimentos de concreto foram baseados na análise das classificações de DNIT (2004), FHWA (2003) e Balbo (2009). Mais especificamente sobre a rede cicloviária da cidade de São Paulo, também foram consideradas as conclusões dos trabalhos de ITDP BRASIL (2015) e Ciclocidade (2018).

\subsection{Defeitos e patologias comuns a pavimentos asfálticos e de concreto}

As fissuras isoladas (figura 24) são caracterizadas por fendas ou rupturas ao longo de faixas perpendiculares, de cantos ou longitudinais, em especial no rebordo do pavimento asfáltico. Este destaque se justifica pelo fato de que, a depender da largura da ciclofaixa, esta área representa o espaço de circulação obrigatória do 
ciclista. Elas podem ser causadas pela má qualidade da estrutura do pavimento, pelas características pedológicas de baixa capacidade de suporte, pela expansão e retração em detrimento da variação térmica e pelo próprio envelhecimento do pavimento. Em geral não são muito graves para a circulação de bicicletas mas, a depender do seu grau de severidade, diminuem o atrito dos pneus com o pavimento e causam a desestabilização da bicicleta, podendo provocar quedas e outros acidentes.

Figura 24 - Exemplos fissuras isoladas
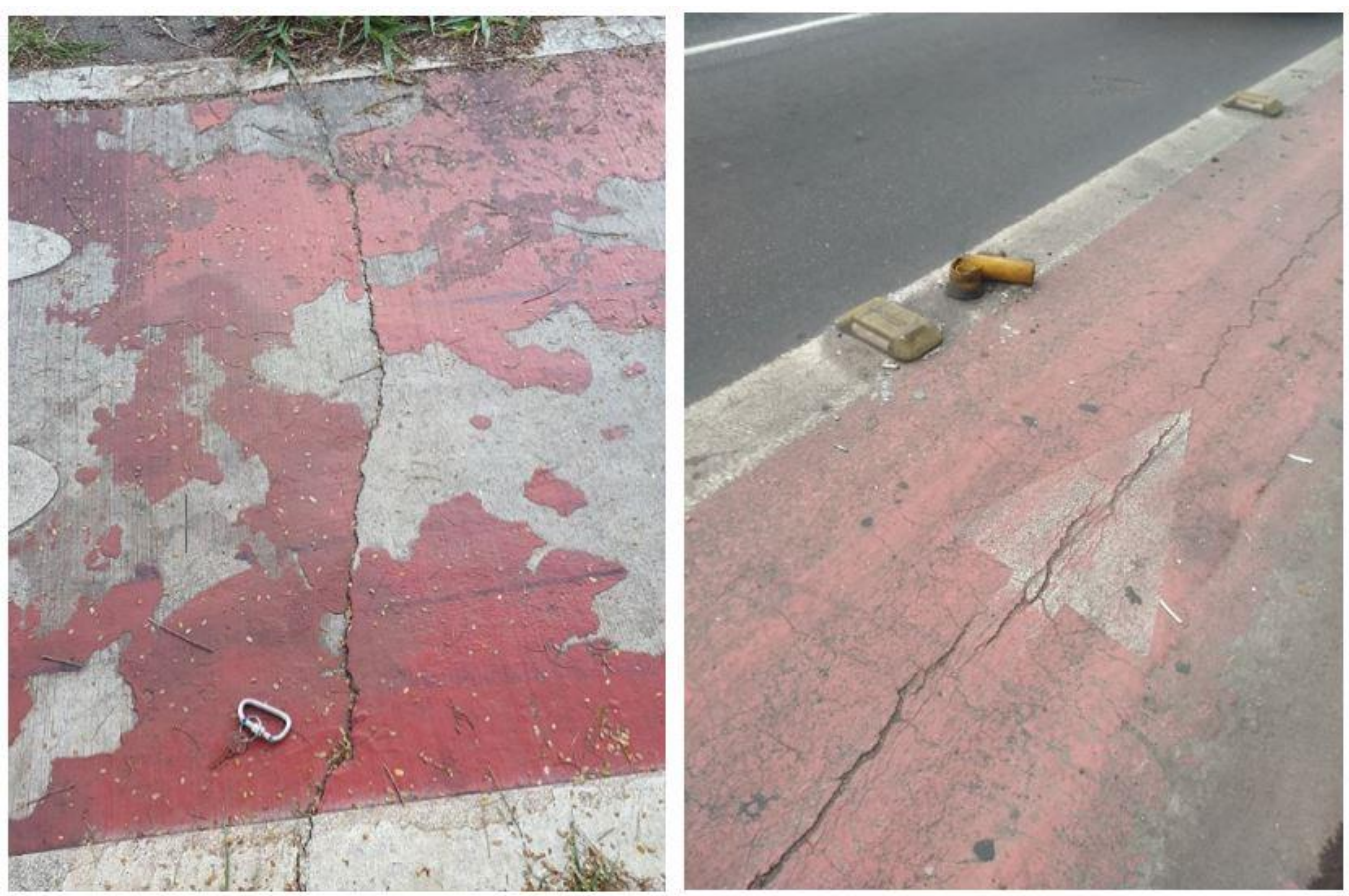

Fonte: o autor

Os buracos (figura 25), como sua própria nomenclatura descreve, são concavidades que ocorrem pela fragmentação do revestimento do pavimento. Seu nível de severidade é mensurado pelas dimensões do defeito e mesmo os de menor nível (profundidades menores que $2,5 \mathrm{~cm}$ e diâmetro menor que $60 \mathrm{~cm}$ ) podem causar desestabilização da bicicleta. 
Figura 25 - Exemplos de buracos
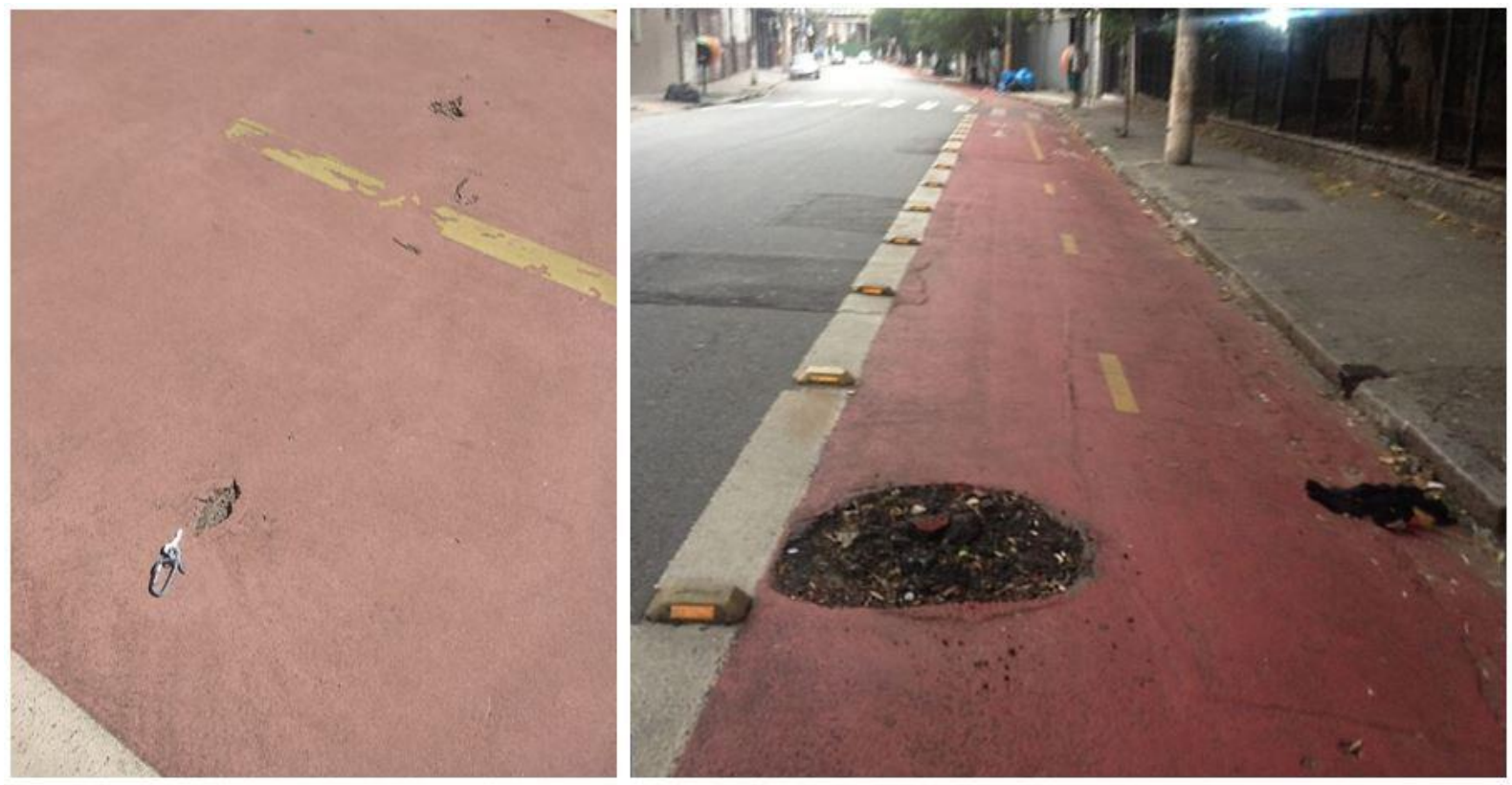

Fonte: $\mathrm{O}$ autor

A cor do pavimento das vias cicláveis também é importante para que o espaço cicloviário se destaque, além de auxiliar na percepção de continuidade de fluxo (CROW, 2007). Por mais que este não seja um defeito em si, mas seja um elemento relacionado a sinalizações, no presente trabalho, ele foi incluído nas análises de qualidade de pavimentos, dado que o desgaste da cor pode ser um indicador da deterioração dos pavimentos.

Vera-Villarroel et al. (2016) analisaram a influência da pintura em 5 cores (amarela, azul, verde, branco e vermelho) em pavimentos de intercessões de ciclofaixas pela percepção de ciclistas em Santiago (Chile). Seus resultados apontaram que a cor vermelha é a que mais distingue o espaço cicloviário da via de automotores e aumenta a percepção de segurança dos ciclistas.

O manual da CET (2014) propõe a coloração das vias cicláveis, apresentado dois padrões de pintura. O Padrão I indica a coloração vermelha em toda largura útil da via ciclável, enquanto o Padrão II apenas indica uma linha vermelha interna à via ciclável, acompanhando as marcas longitudinais. Dado a importância que a pintura do pavimento tem na melhoria da infraestrutura cicloviária, o Padrão II diminui consideravelmente essa vantagem, ao manter a cor original do pavimento asfáltico. 
Desta forma, a cor vermelha dos pavimentos aumenta a segurança do ciclista ao distinguir o espaço cicloviário do leito carroçável de automóveis e até mesmo dos pedestres. Assim, como nas vistorias preliminares foi constatado que o desgaste da cor do pavimento (figura 26) se relaciona com níveis de deterioração da via ciclável, este elemento foi incluído neste catálogo como um defeito.

Figura 26 - Exemplos de desgaste da cor do pavimento
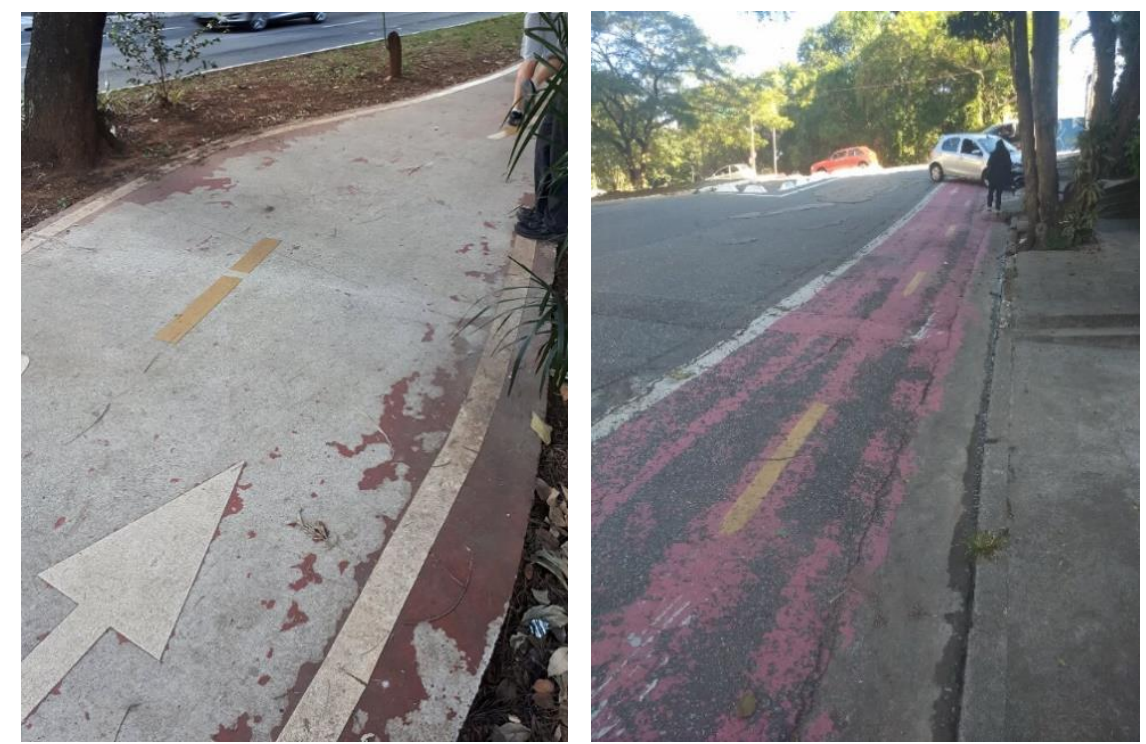

Fonte: o autor

A ocorrência de remendos (figura 27), por mais que seja uma ação de manutenção para sanar problemas nos pavimentos, foi compreendida como um defeito porque sua implementação e envelhecimento podem estar associados a afundamentos, mudanças de textura, e desnivelamentos com o pavimento original. Ademais, a depender da qualidade do novo material e da sua aplicação, mais facilmente podem sofrer desgaste e possível desprendimento. 
Figura 27 - Exemplos de remendos
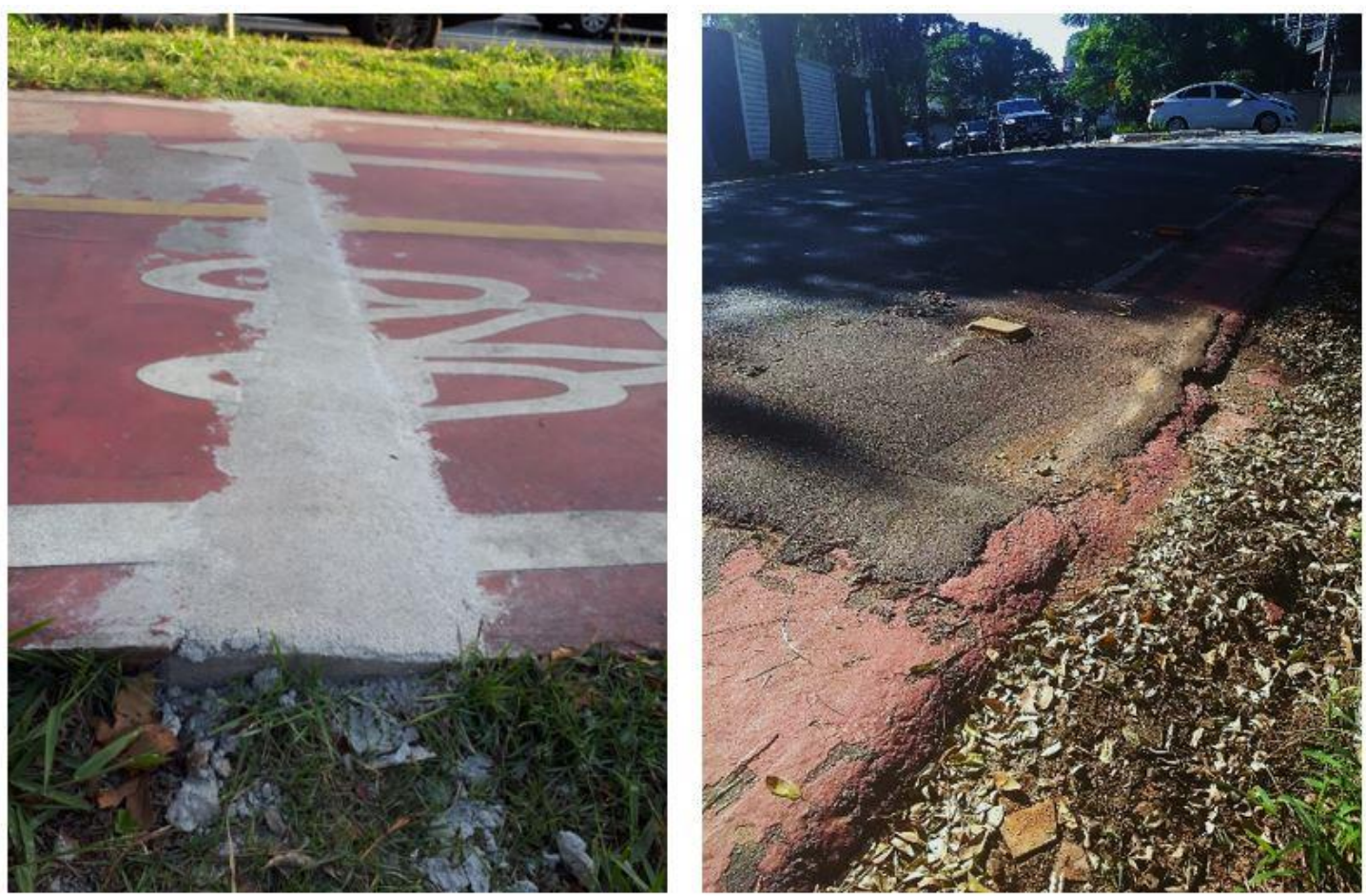

Fonte: o autor

A presença das tampas de poços de visita de aço ou concreto (PV) ou bocas de lobo (figura 28), por mais que não se configurem como um defeito propriamente dito, podem causar desestabilização do ciclista pela sua existência ou mesmo por um possível afundamento.

Figura 28 - Exemplos de tampas de poços de visita ou Bocas de Lobo
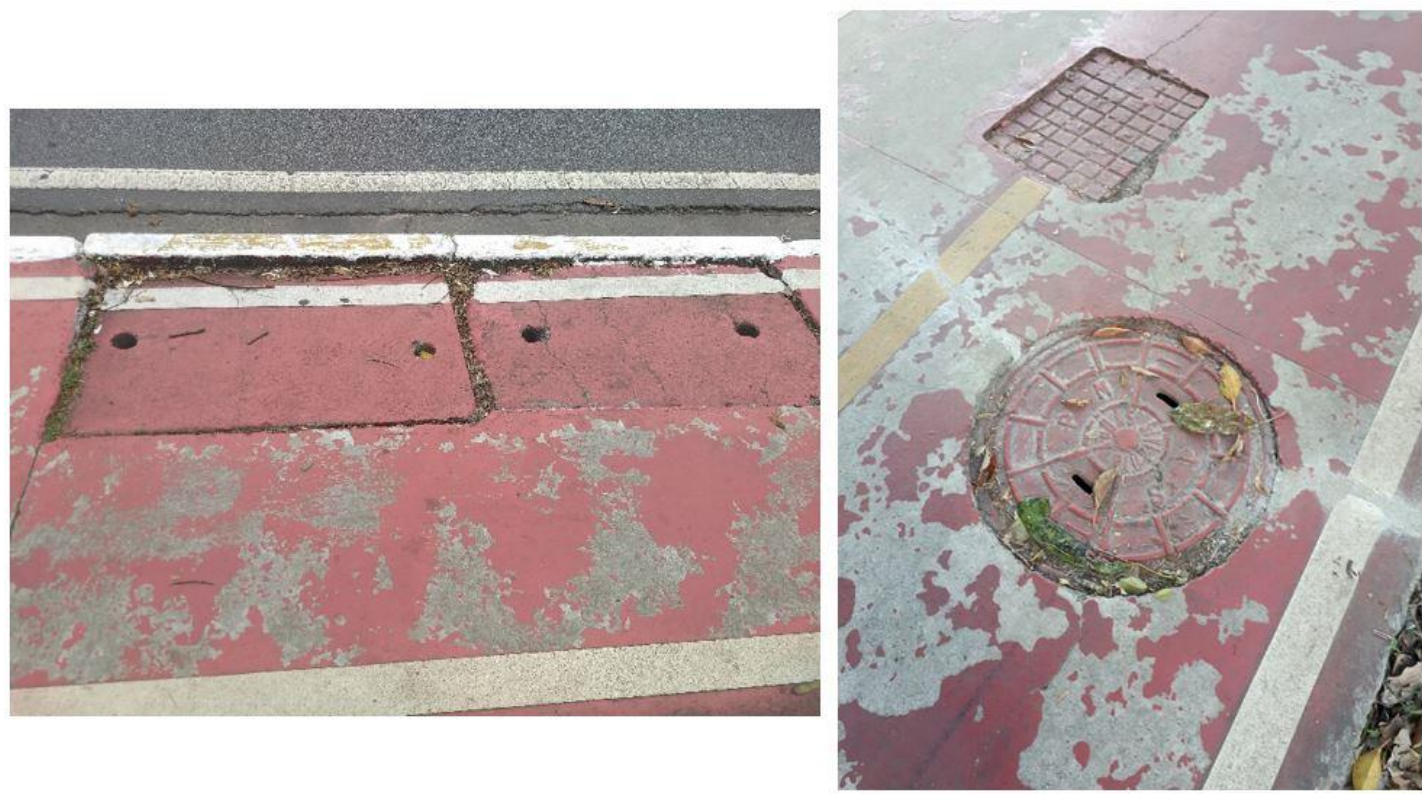

Fonte: o autor 


\subsection{Defeitos e patologias de pavimentos asfálticos}

As fissuras em blocos (figura 29) são definidas como um agrupamento de trincas isoladas, que se interligam perpendicular e paralelamente ao eixo da via. Elas indicam uma deterioração maior do pavimento e propõem maior vibração ao rolamento da bicicleta.

Figura 29 - Exemplos de fissuras em blocos
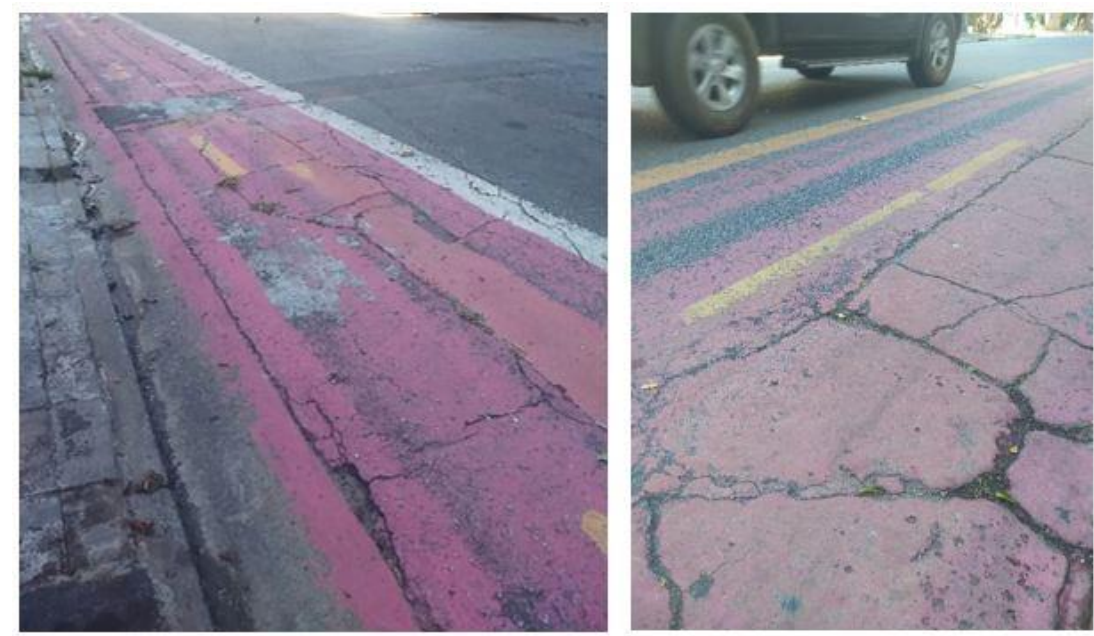

Fonte: o autor

Os afundamentos (figura 30) são concavidades que podem ocorrem em qualquer parte da superfície do terreno e, além de desconforto, podem vir a causar o desequilíbrio e queda do ciclista. Seu nível de severidade se dá pela profundidade e diâmetro do defeito, mas mesmo os de menores dimensões podem aumentar o risco a derrapagem pelo acúmulo de água no pavimento.

Figura 30 - Exemplos de afundamentos

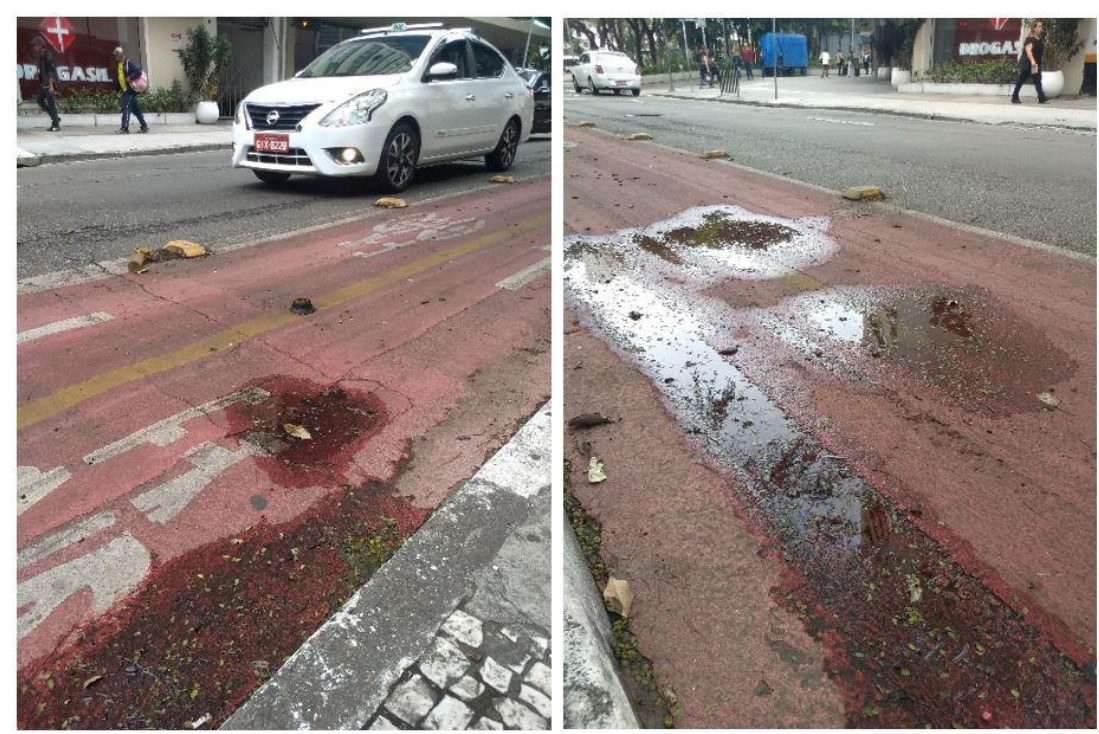

Fonte: o autor 
Os escorregamentos (figura 31) são deslocamentos no sentido transversal da mistura asfáltica associados a depressões e elevações locais. Como se localizam próximo às bordas da pista de rodagem acabam se localizando no eixo central do percurso do ciclista, sobretudo nas que possuem as sarjetas como parte da via ciclável.

Figura 31 - Exemplos de escorregamentos
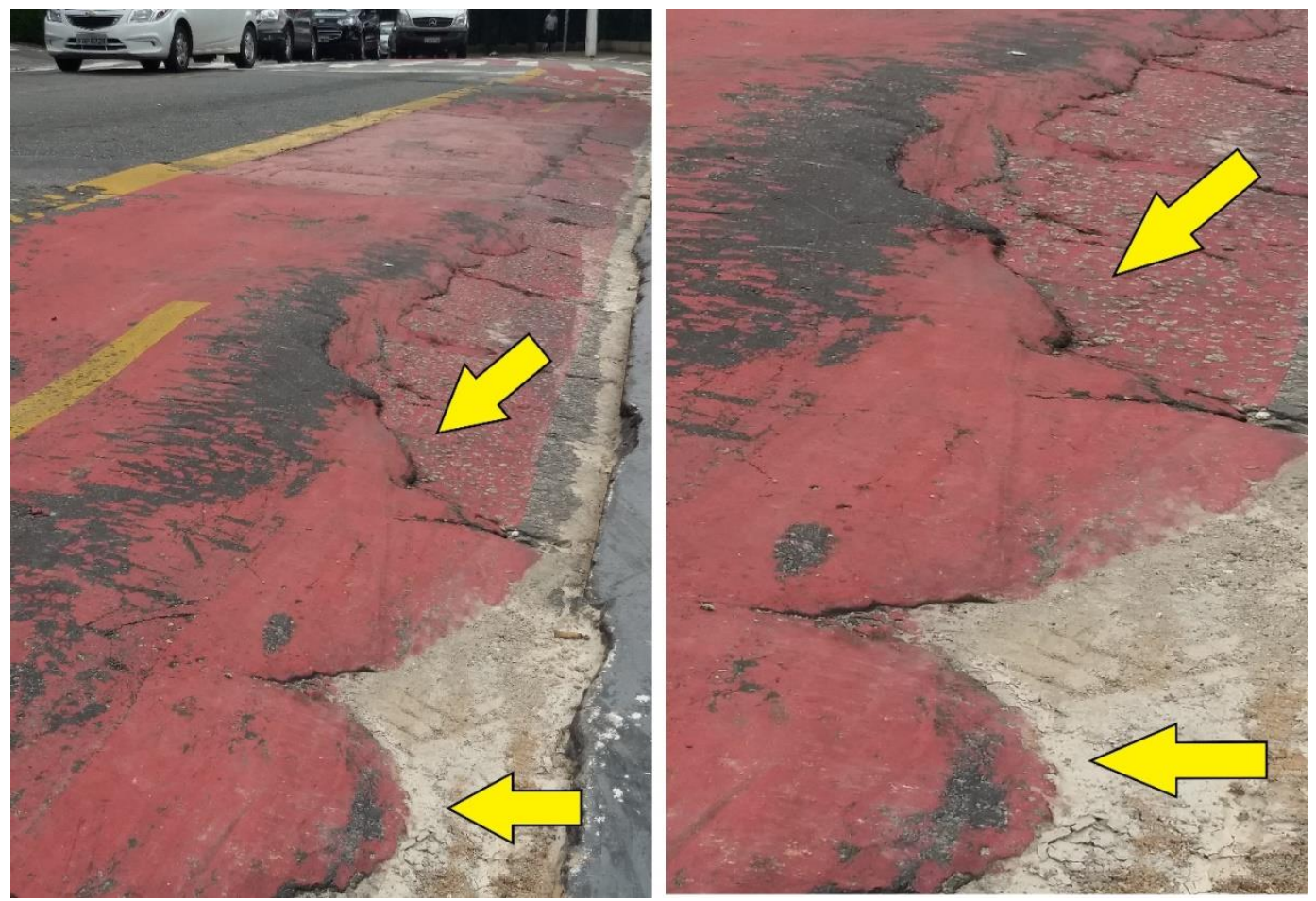

Fonte: o autor

Um defeito encontrado em todas as vias nas vistorias prévias é a sarjeta como parte da largura útil da via ciclável (figura 32). Por mais que no manual da CET (2014) esteja previsto este tipo de implementação, não é um cenário ideal para a circulação de bicicletas. A diferença do tipo de pavimento pode causar desconforto ao ciclista e a frequente não distinção de cor (no manual há a indicação de que a sarjeta também seja pintada de vermelho) pode causar confusão ao ciclista ao não perceber a diferença de níveis que há entre a via ciclável e a sarjeta. 
Figura 32 - Exemplo de sarjeta como parte da largura útil da via ciclável

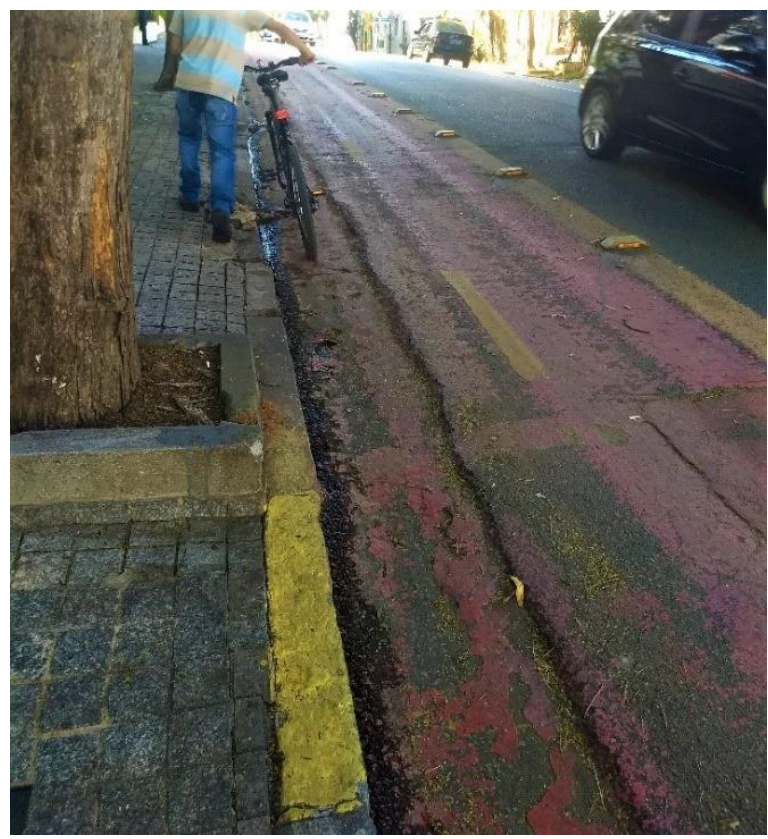

Fonte: o autor

Esta característica muito frequente de implementação também pode levar a outros problemas, como o desnível entre via ciclável e a sarjeta (figura 33). A relação desnivelada entre elas pode determinar dificuldades para o ciclista, sobretudo em vias de pouca largura, causando desestabilização e risco de queda para o ciclista.

Figura 33 - Exemplo de desnível entre via ciclável e sarjeta

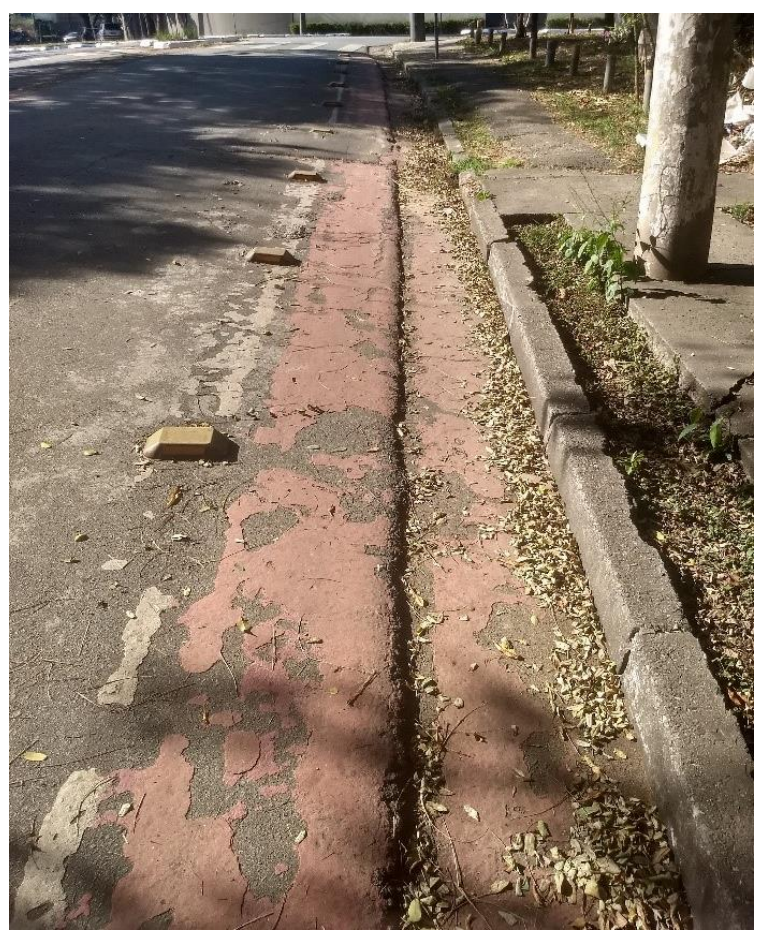

Fonte: o autor 
Defeitos relacionados não apenas à má implementação da infraestrutura viária também foram identificados. A figura 34 exemplifica as grelhas de sarjeta com espaçamento longitudinal acentuado (maiores que $2 \mathrm{~cm}$ ) que podem provocar 0 encaixe e travamento do pneu da bicicleta durante o percurso do ciclista.

Figura 34 - Exemplos de grelhas de sarjeta com espaçamento longitudinal
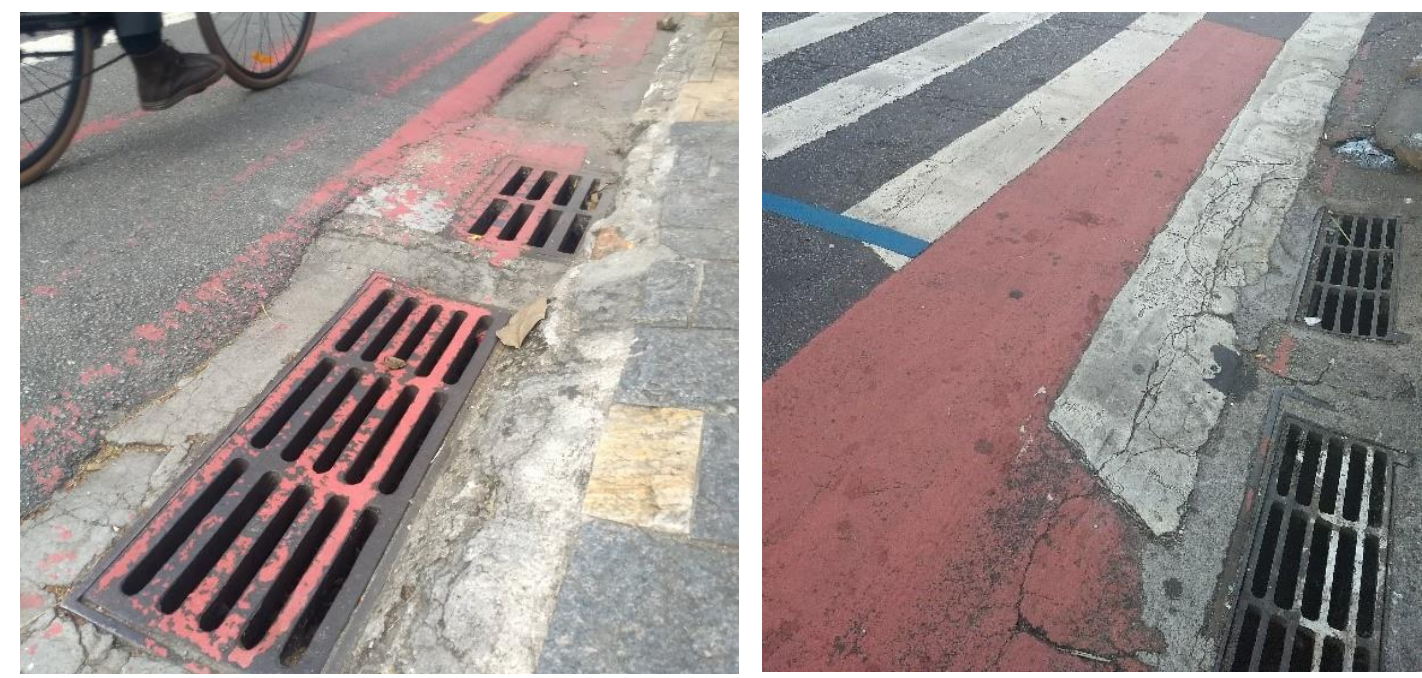

Fonte: o autor

Outro tipo de defeito relacionado à drenagem urbana são as valetas em intercessões (figura 35). Por mais que sejam necessárias ao escoamento de água superficial, elas interferem na circulação da bicicleta, quase se mostrando como um obstáculo. Inclusive há risco de desequilíbrio e queda para cicilstas menos experientes, sobretudo nas conversões de saída e entrada da ciclofaixa. Ademais, por conta chuvas, muitos detritos e resíduos sólidos podem acompanhar 0 escoamento pluvial e acabar se localizando especialmente nas valetas, o que pode obstaculizar a via. 
Figura 35 - Exemplos de valetas em intercessões

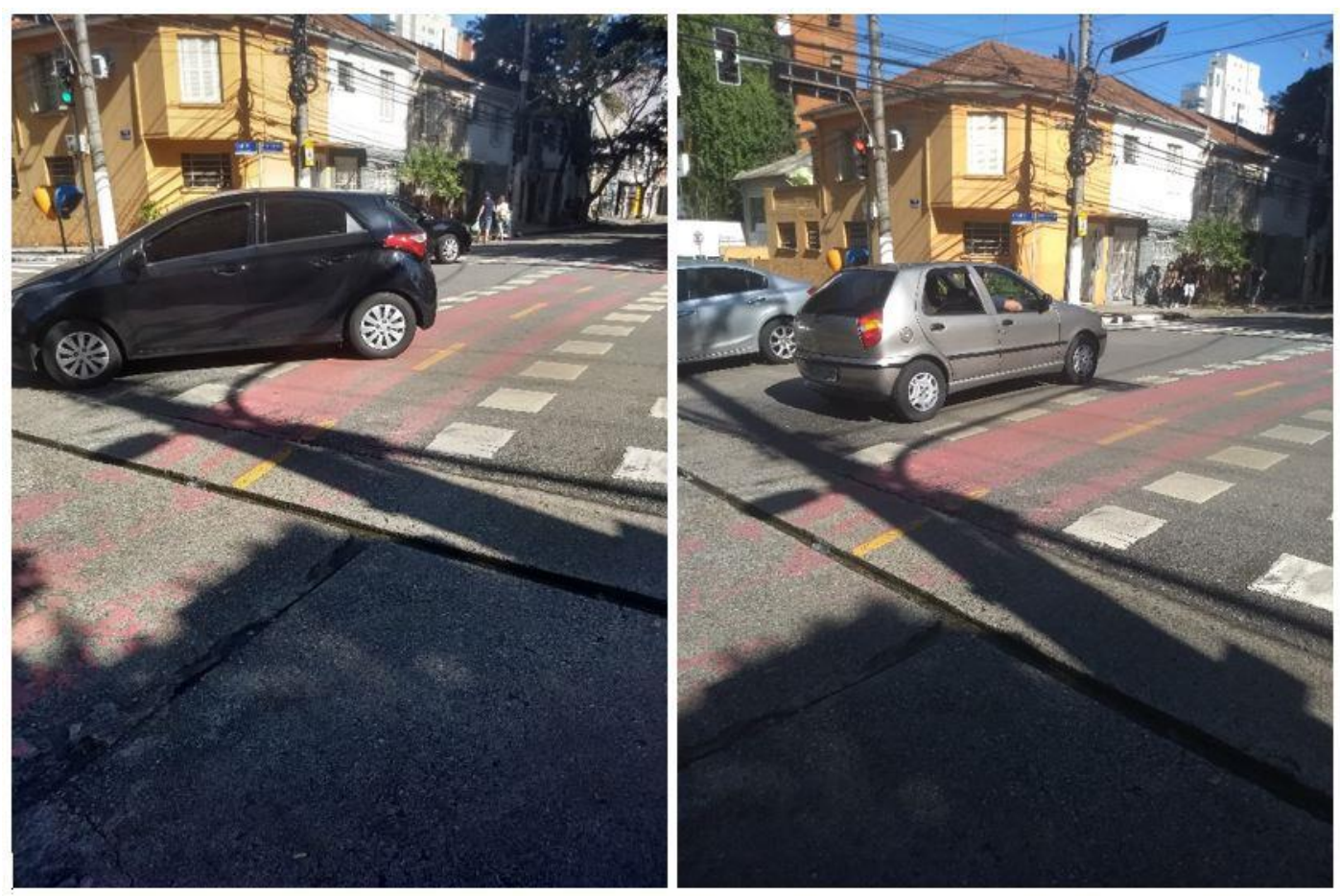

Fonte: o autor

As rampas de acesso de estacionamentos (figura 36), que fazem com que os automóveis superem mais facilmente a diferença de níveis entre a sarjeta e a calçada, são um problema para os ciclistas, dado que bruscamente impedem seu trajeto. Muitas dessas rampas são feitas irregularmente sobre as ciclofaixas sem incluir qualquer tipo de sinalização ou pintura em vermelho.

Figura 36 - Exemplos de rampas de acesso de estacionamentos
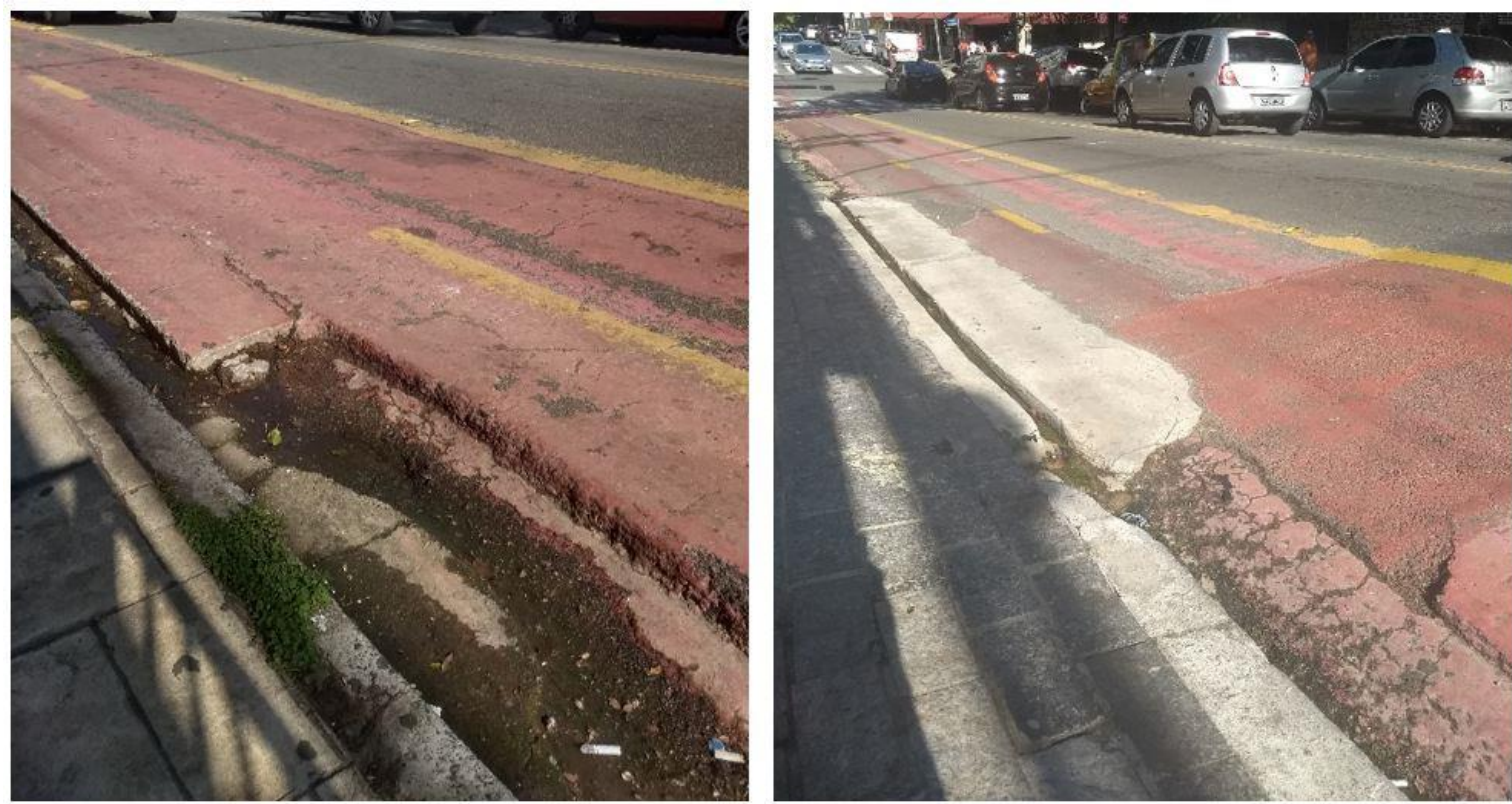

Fonte: o autor 


\subsection{Defeitos e patologias de pavimentos de concreto}

As quebras (figura 37) se caracterizam como uma cisão em uma área da placa (em geral, nos cantos ou transversalmente à placa), de modo que partes se deslocam vertical e/ou horizontalmente. Em geral, podem ser o resultado da evolução de fissuras, mas também podem ocorrer devido a externalidades, como o crescimento de raízes ao lado da ciclovia.

Figura 37 - Exemplos de quebras
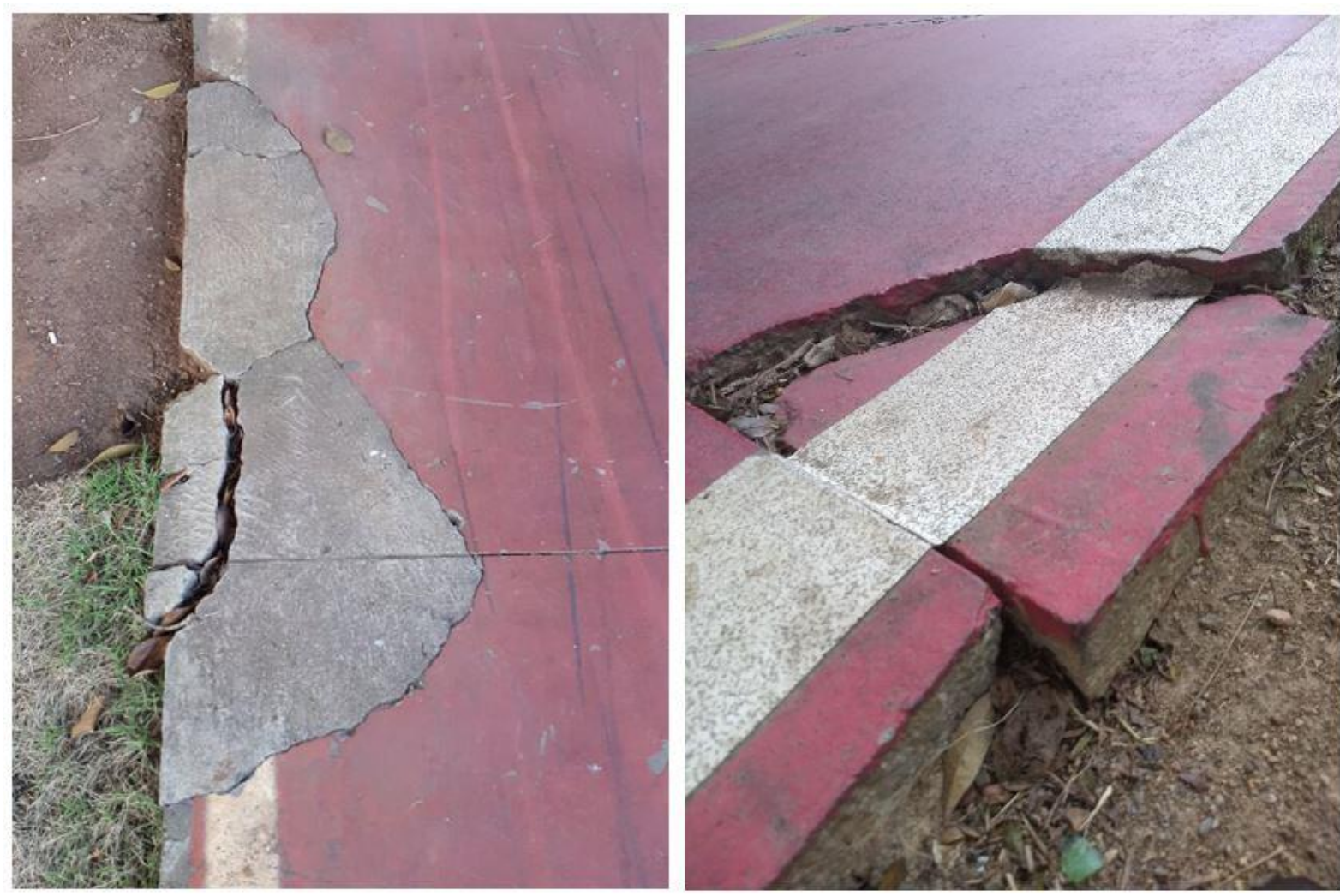

Fonte: o autor

O esborcinamento de juntas (figura 38) se caracteriza pela quebra em cunha, gerando pequenos espaços entre as placas. Para as vias cicláveis não foi localizado exemplos de alto nível de severidade, tendo em vista que sua gênese está relacionada com o tráfego intenso de automóveis. Contudo, este defeito é um indicador da deterioração do pavimento e causa maior vibração e consequente desconforto ao ciclista. 
Figura 38 - Exemplos de esborcinamento de juntas
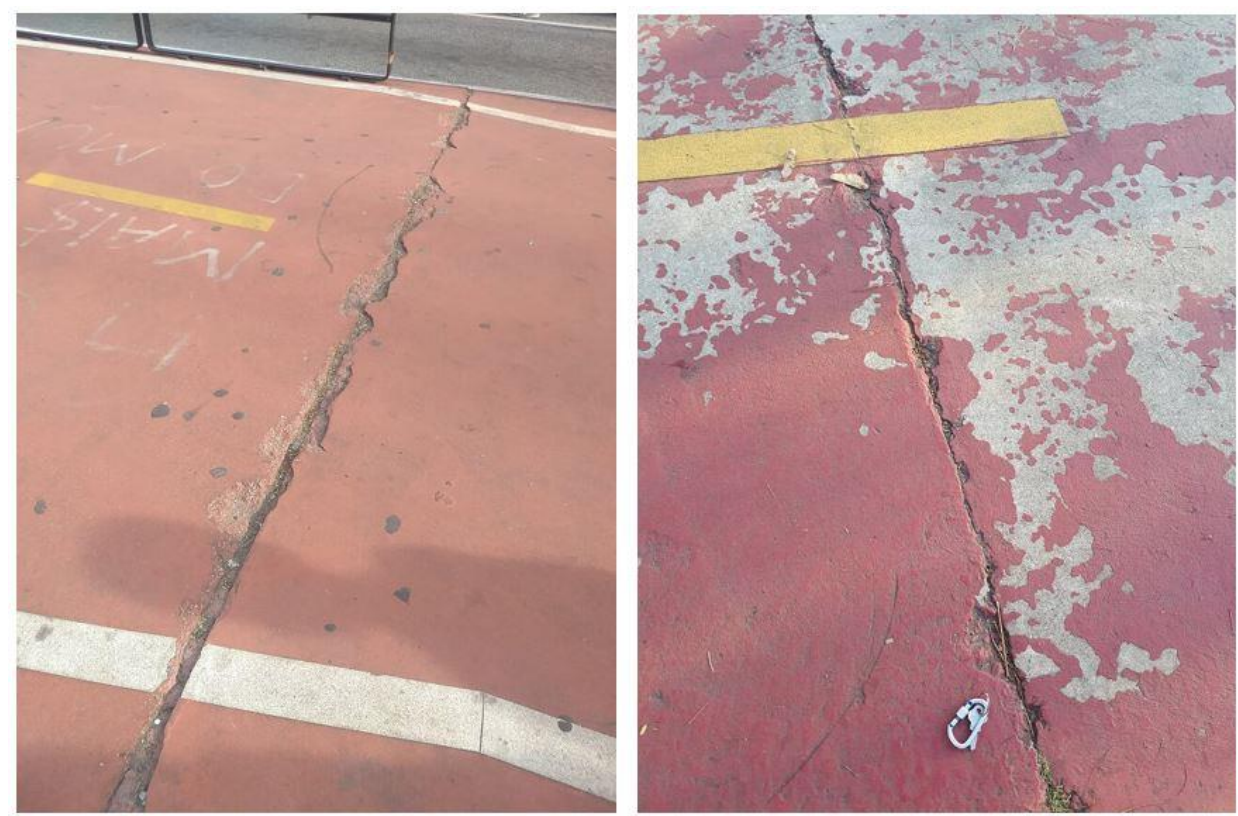

Fonte: o autor

Já o escalonamento de juntas (figura 39), que é caracterizado por deslocamentos verticais entre placas adjacentes, indica problemas significativos ao movimento da bicicleta. Como forma um degrau entre as placas, este defeito pode impedir o movimento da roda dianteira, interrompendo o movimento e favorecendo a queda do ciclista.

Figura 39 - Exemplos de escalonamento de juntas

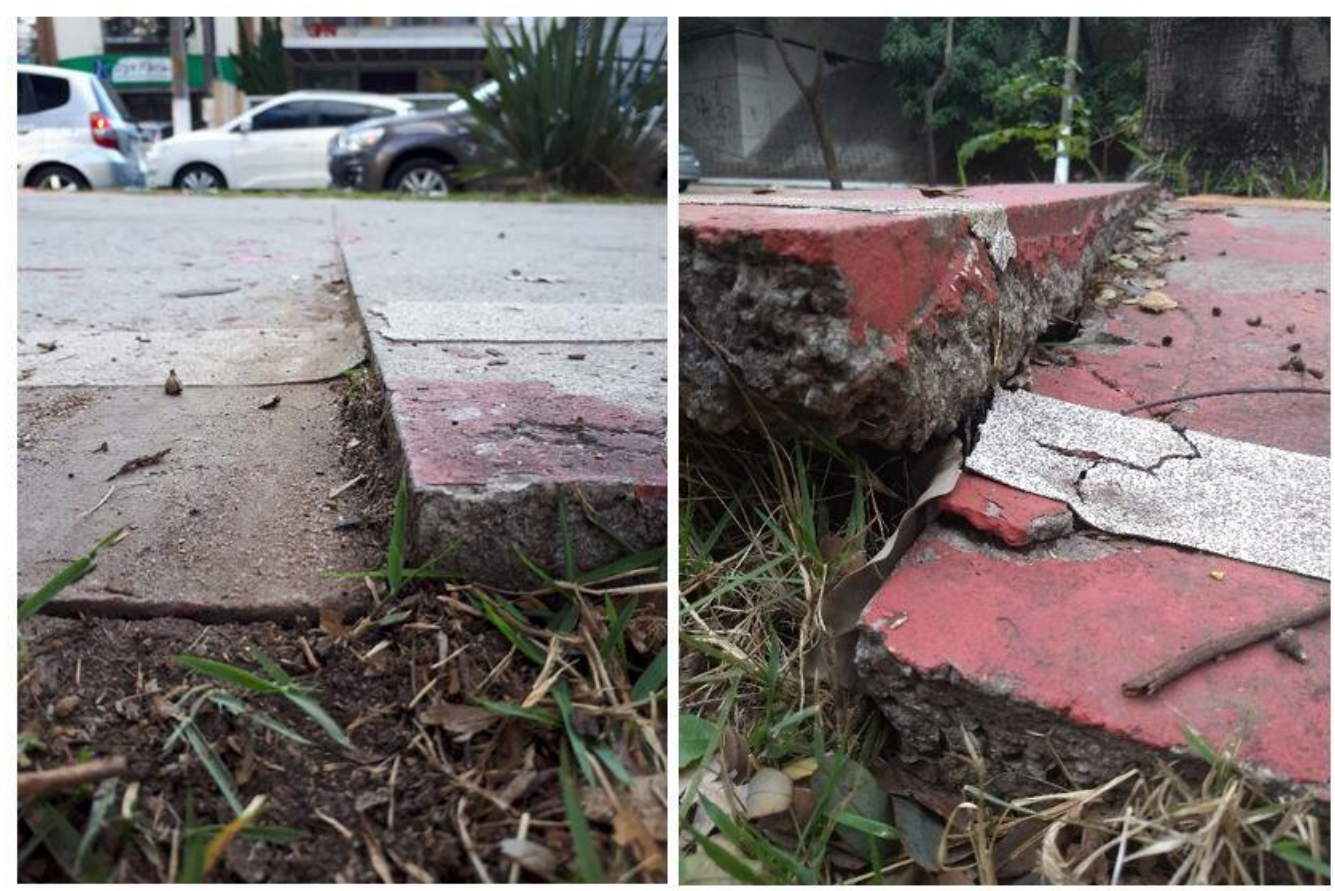

Fonte: o autor 
A separação de juntas (figura 40) pode ocorrer por processos diferentes, como falha da selagem ou mesmo alto nível de deterioração de quebras, com a remoção de material do pavimento. Além do aumento do desconforto do ciclista ao propor uma variação vertical ao trajeto, também pode provocar desde o acúmulo de materiais até o crescimento de vegetação.

Figura 40 - Exemplos de separação de juntas
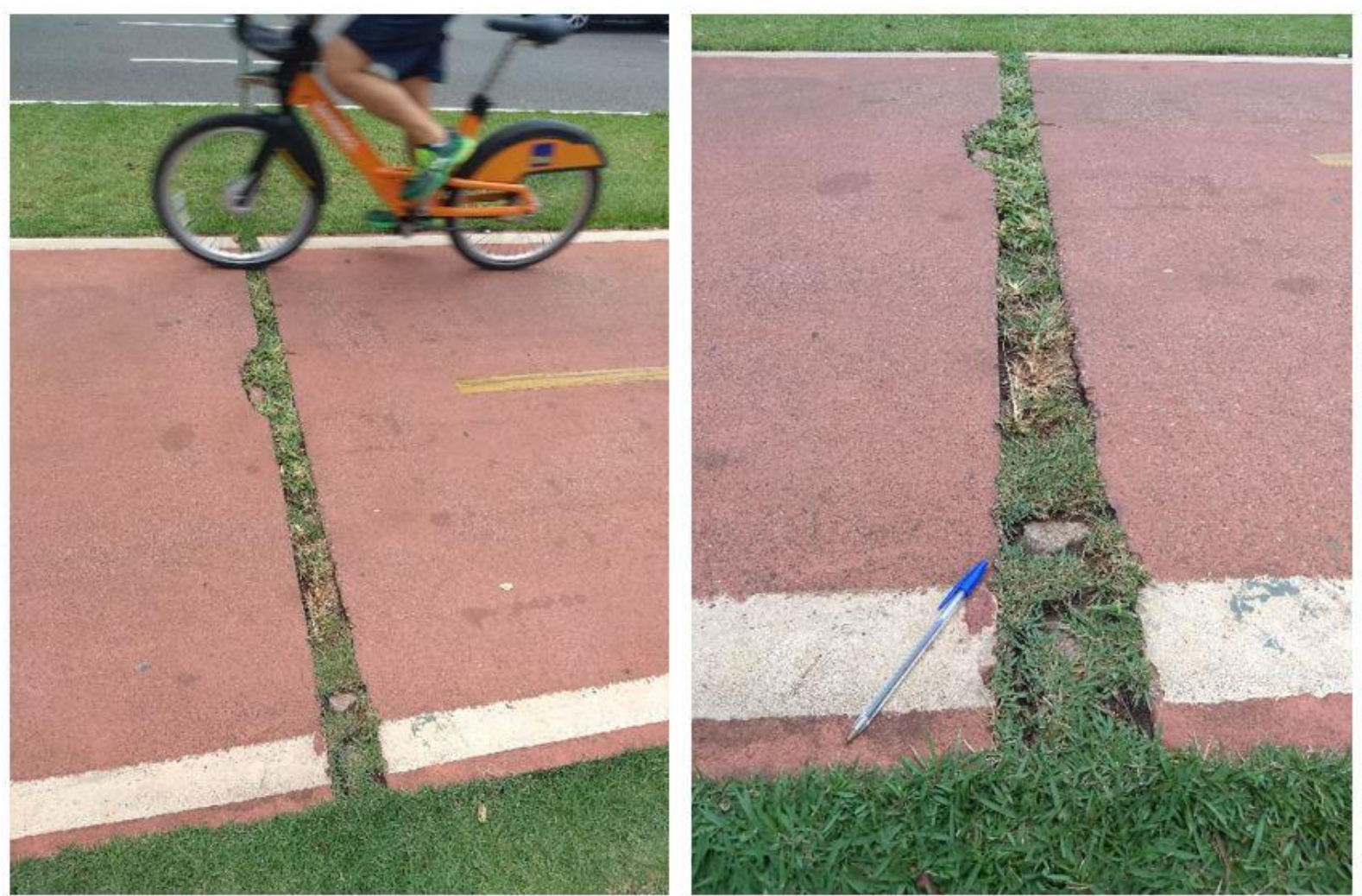

Fonte: o autor

O alçamento (figura 41) é caracterizado pelo desnivelamento transversal em uma placa ou entre placas. É causado pela evolução de quebras ou por pressão e esmagamento (oriundos de esforços horizontais, como frenagens) de placa contra placa. Este defeito não necessariamente causa problemas ao ciclista, pois pode indicar apenas pequenas rampas ascendentes e descendentes. Contudo, se o nível de severidade for alto, oferecerá uma mudança abrupta no alinhamento vertical do movimento do ciclista, afetando seu conforto e estabilidade. 
Figura 41 - Exemplo de alçamento

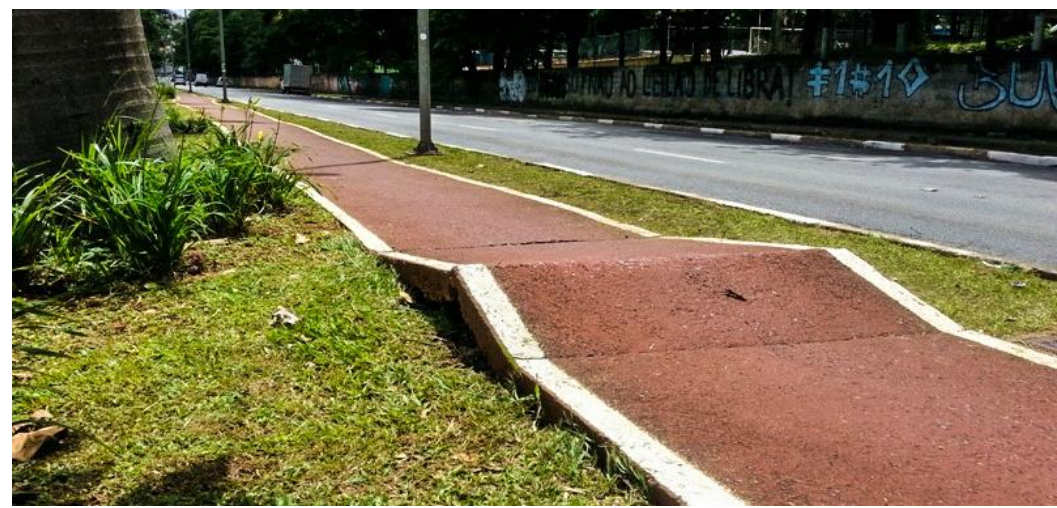

Fonte: CACIOLI, N. ${ }^{7}$

As juntas de transição (figura 42) são encontradas nos cruzamentos das ciclovias com ruas e avenidas, propondo uma mudança vertical ao nível dos automóveis. Não é especificamente um defeito, mas uma solução para intercessões. Entrentato, a depender da gradação angular, elas podem causar significativo desconforto na saída ou na entrada e dificuldades para ciclistas iniciantes ou crianças. Como também são áreas de encontro de dois materiais diferentes (pavimentos asfálticos das ruas e de concreto das ciclovias) e de maior atrito entre pneu e pavimento, podem apresentar uma deterioração maior que as outras partes das placas. Uma alternativa para esta solução geométrica seria a implantação de travessias elevadas ou "lombofaixas".

Figura 42 - Exemplos de juntas de transição
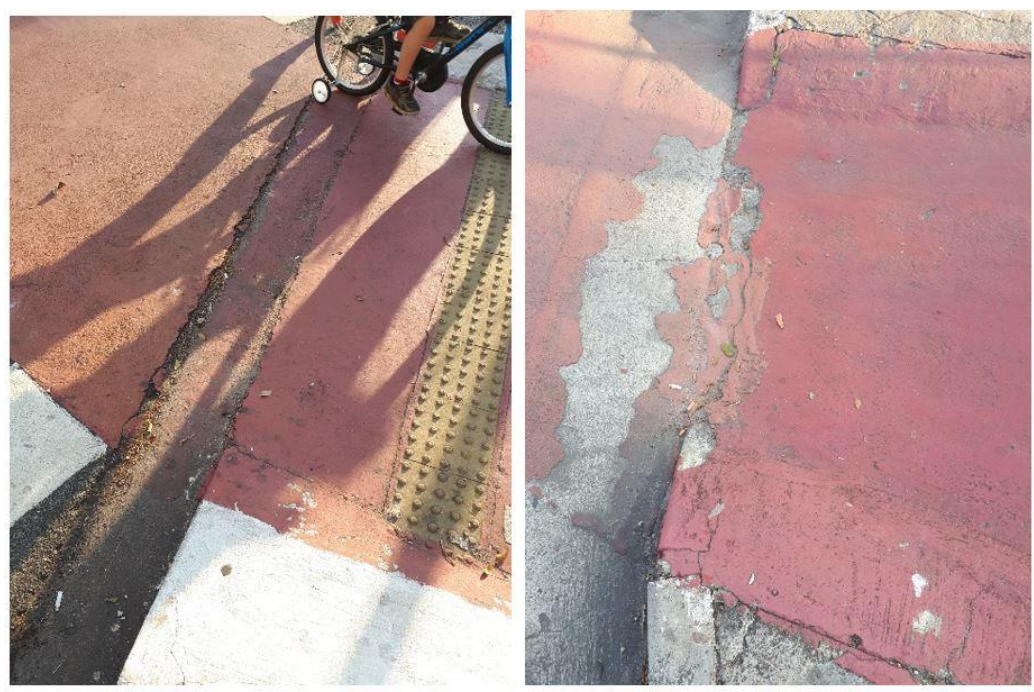

Fonte: o autor

${ }^{7}$ CACIOLI, N. Testes nas ciclovias de São Paulo. INFOGRÁFICOS ESTADÃO. São Paulo, SP, [201-]. Disponível em <http://infograficos.estadao.com.br/public/cidades/ciclovias/>. Acesso em: 14 mai. 2019. 


\subsubsection{Questionário de percepção comparada}

Para que fosse possível avaliar objetivamente como cada defeito e patologia descritos anteriormente afetam o conforto e a segurança dos ciclistas, foi proposta a aplicação de um questionário para captar a percepção comparada entre os defeitos.

O questionário foi aplicado de forma on-line pela plataforma livre Google Forms, de modo que todos os dados já fossem cadastrados e tabulados assim que o participante encerrasse todas as respostas. Como um dos objetivos da pesquisa foi coletar a experiência de usuários que efetivamente utilizam o sistema cicloviário de São Paulo, o questionário foi direcionado a grupos de redes sociais (Whatssap e Facebook) de pessoas que possuem algum vínculo com o tema de bicicletas. Por exemplo, ciclistas (que usam diariamente ou não), ativistas, profissionais do mercado ciclístico e interessados neste tema.

Foram propostas questões em três eixos, apresentados a seguir.

1. Sobre o perfil do ciclista:

a. Quantos anos você tem?

b. Qual a sua profissão?

c. Qual seu gênero?

d. Há quanto tempo você usa a bicicleta para se deslocar na cidade?

2. Sobre a rotina do ciclista:

a. Por qual motivo você usa a bicicleta para se deslocar na cidade?

b. Qual a frequência que você usa a bicicleta para se deslocar para suas principais atividades no dia (ir à escola, ao trabalho, lazer etc.)?

3. Sobre a percepção de conforto e segurança do ciclista:

Foram apresentados os defeitos e patologias compilados neste trabalho com imagens explicativas e foi sugerido para que o entrevistado desse notas de como cada um influencia o conforto e segurança em vias clicáveis. Seguindo uma escala ordinal de mensuração multi-item de cinco pontos, as notas variaram de 1 (defeito pouco ou nada importante) a 5 (defeito muito grave). Por mais que as questões se relacionem em certa medida, suas as respostas esperadas são independentes e, como não se pretendeu traçar um perfil isolado de cada entrevistado, mas sim 
de cada defeito, pode-se designar este grupo de questões como sendo do Tipo Likert (Clason e Dormody, 1994).

A figura 43 apresenta um exemplo de questão do terceiro eixo e o Apêndice $A$ apresenta o fac-símile completo do questionário.

Figura 43 - Exemplo de questão

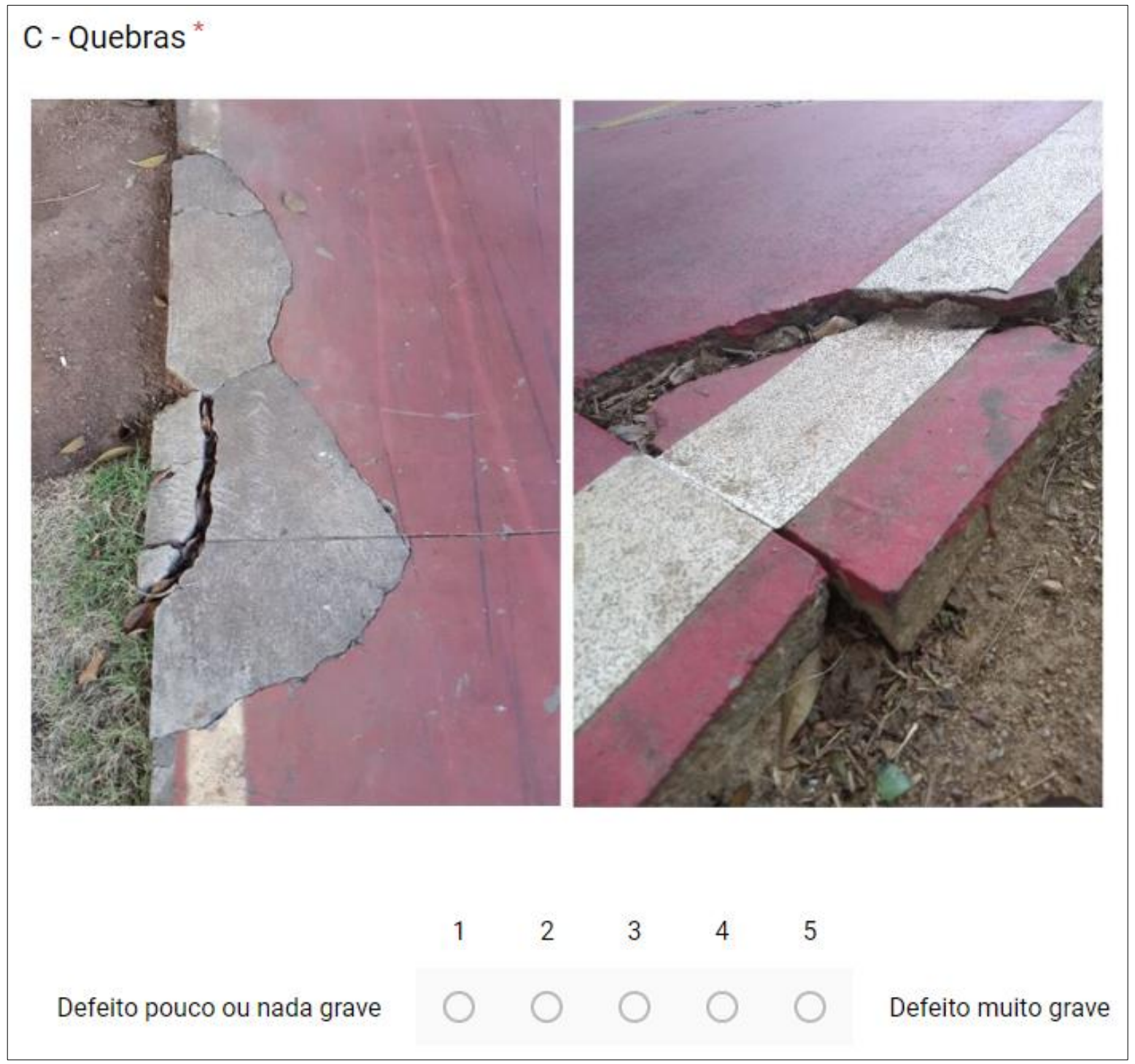

Fonte: o autor

\subsubsection{Inventário geral de defeitos e patologias}

Como explicitado anteriormente, o diagnóstico da situação funcional das vias de um sistema viário é essencial para que o gestor tenha a real noção de como proceder nas suas tomadas de decisão. Desta forma, foram realizadas vistorias para a identificação dos defeitos e patologias em cada um dos segmentos definidos. 
Nelas foram quantificados ou categorizados os problemas listados no quadro 5 , de modo que pudessem ser inseridos nas análises propostas neste trabalho. $O$ facsímile das fichas de campo estão representadas nos quadros a seguir.

Quadro 6 - Ficha do inventário geral de defeitos em pavimentos asfálticos

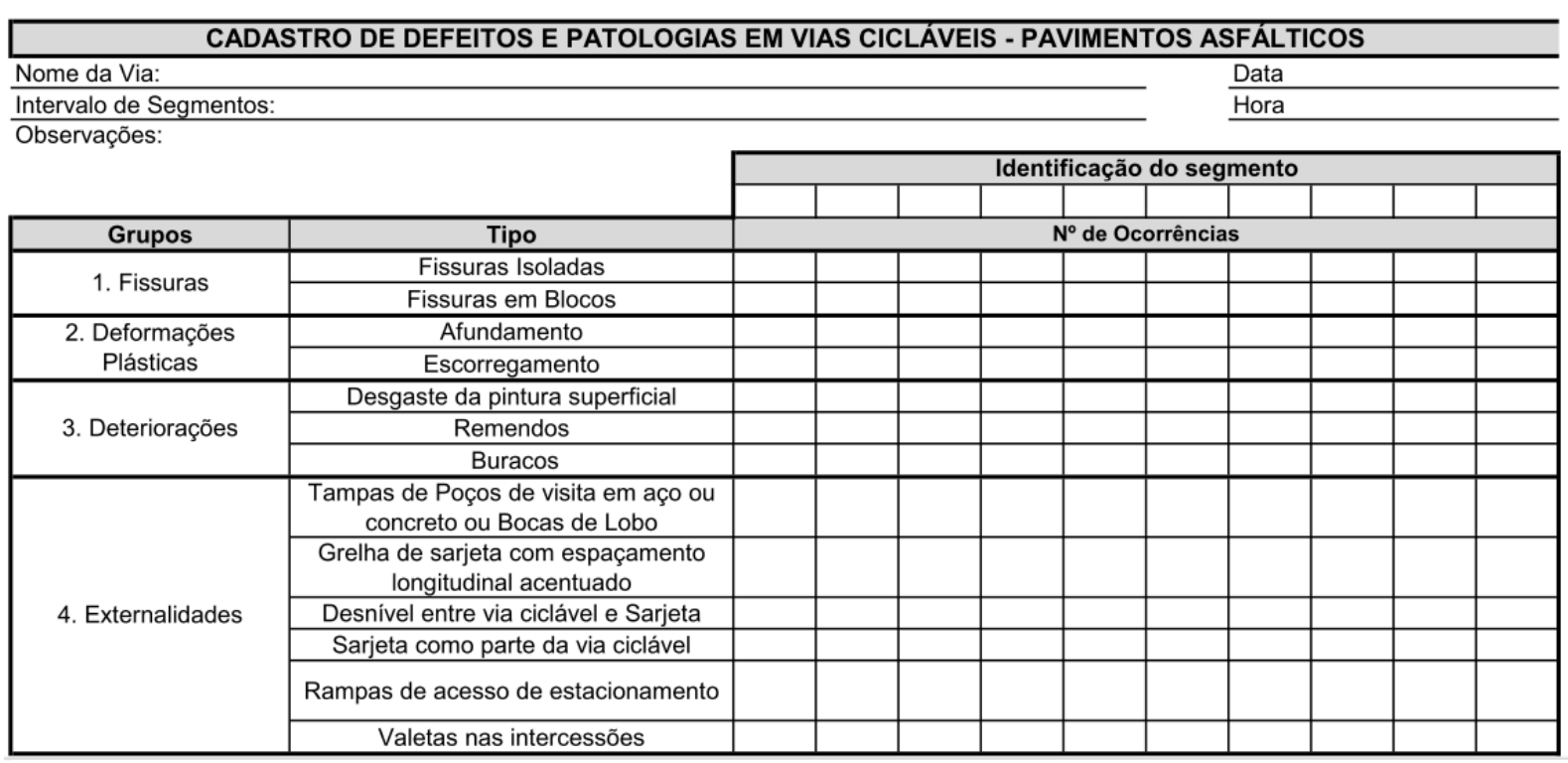

Fonte: o autor

Quadro 7 - Ficha do inventário geral de defeitos em pavimentos de concreto CADASTRO DE DEFEITOS E PATOLOGIAS EM VIAS CICLÁVEIS - PAVIMENTOS DE CONCRETO

Nome da Via:

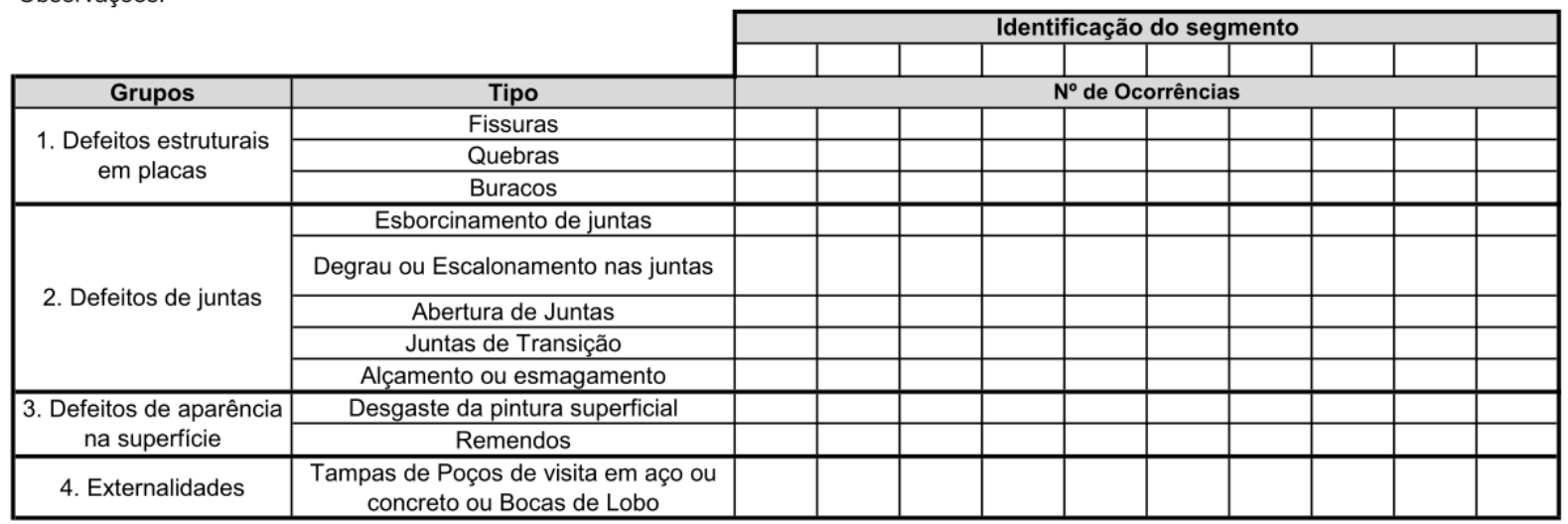

Fonte: o autor

As vistorias foram feitas a pé e por apenas uma pessoa para que a identificação e contagem dos defeitos fosse o mais coerente possível com o 
catálogo. Contudo, a subjetividade do técnico de campo sempre é um elemento a se considerar neste tipo de avaliação.

Segundo Solminihac-Tampier (2001), a primeira exigência de uma avaliação de pavimentos é a consistência de seu banco de dados. Sem instruções detalhadas e treinamento de identificação, as bases de dados serão inconsistentes o que dificulta a análise e tomada de decisões corretas.

Desta forma, foi produzido um guia com chaves de interpretação dos defeitos e instruções para identificação em campo, apresentado no quadro 8.

Quadro 8 - Guia para interpretação de defeitos e patologias em vias cicláveis

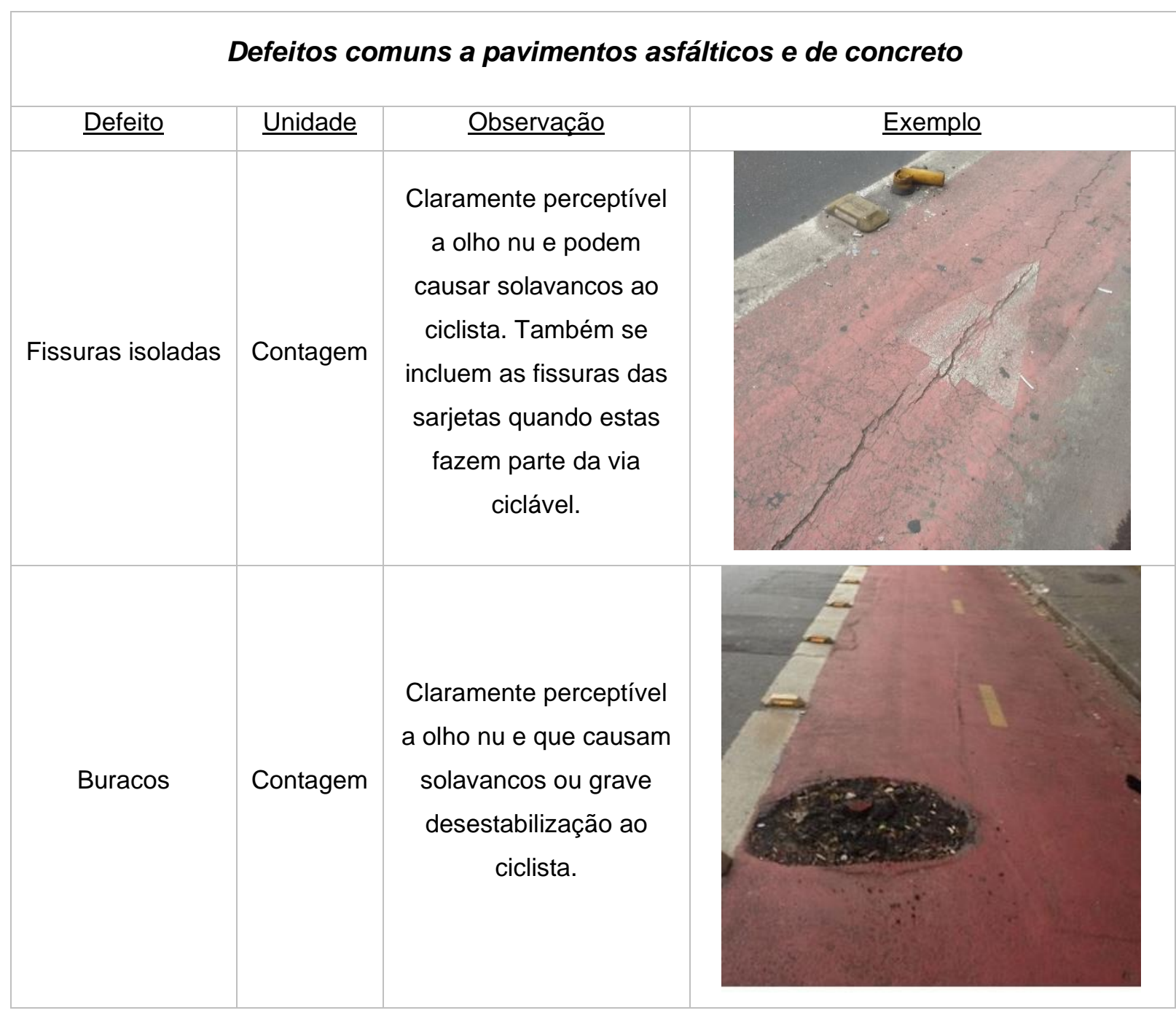




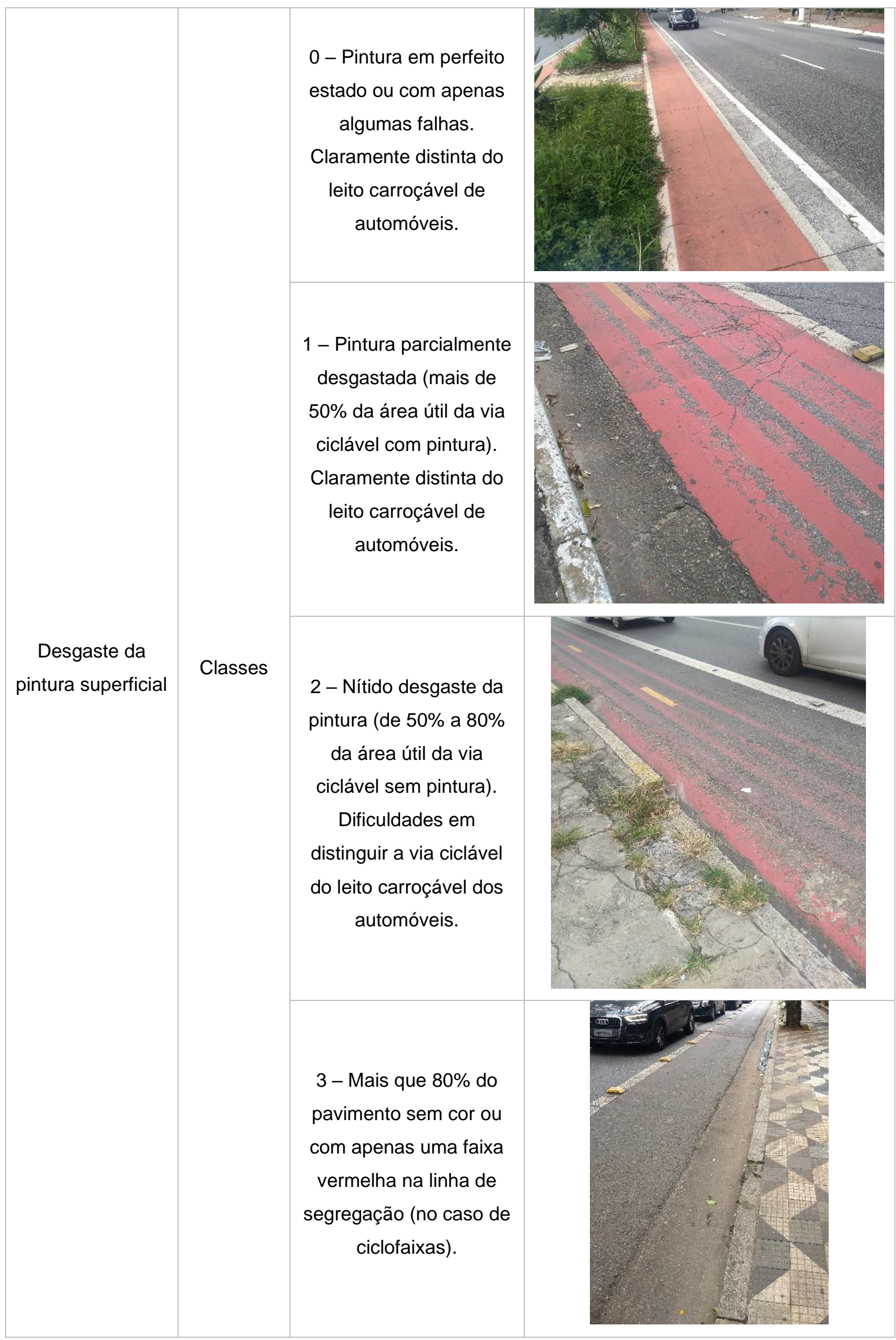




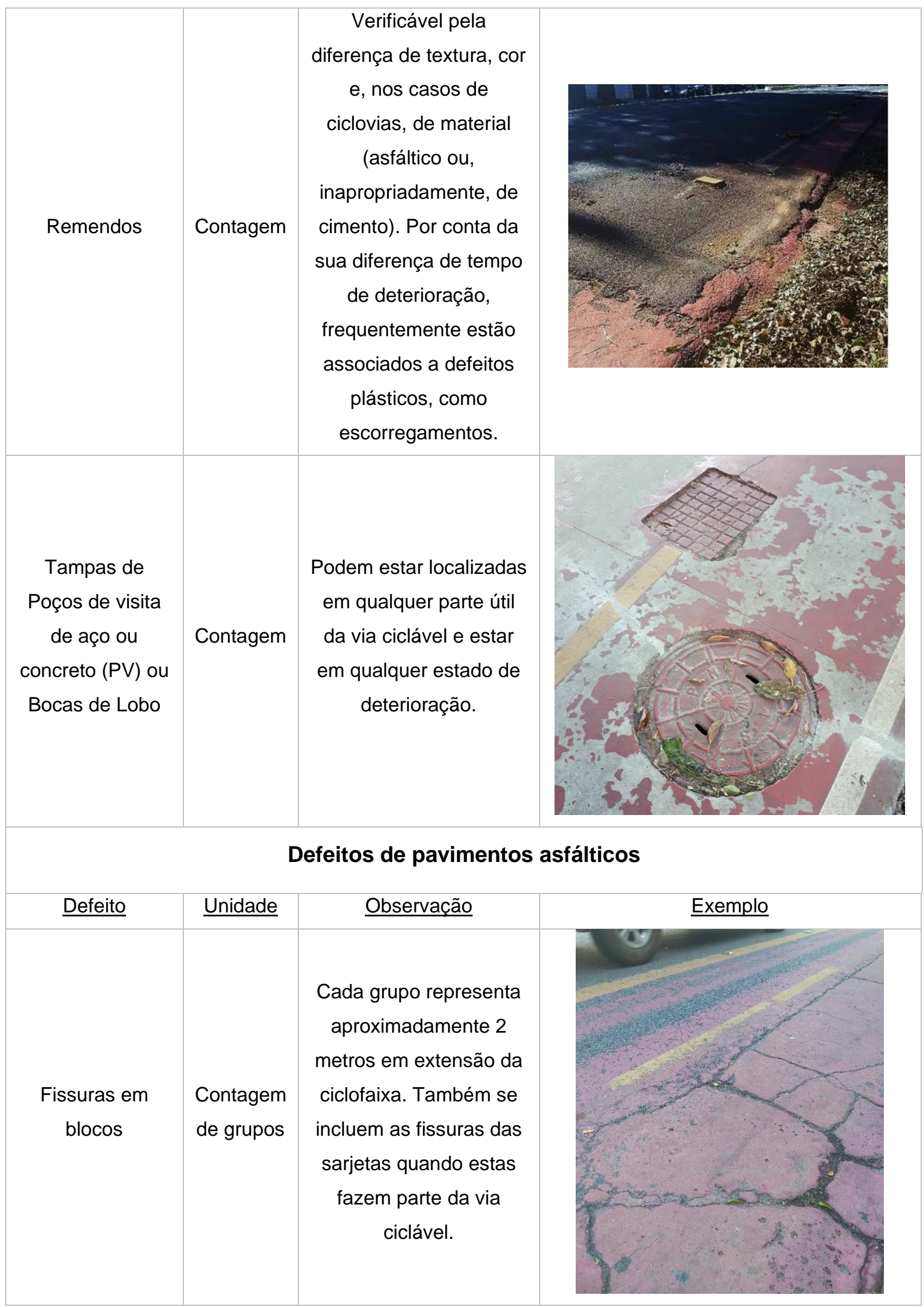




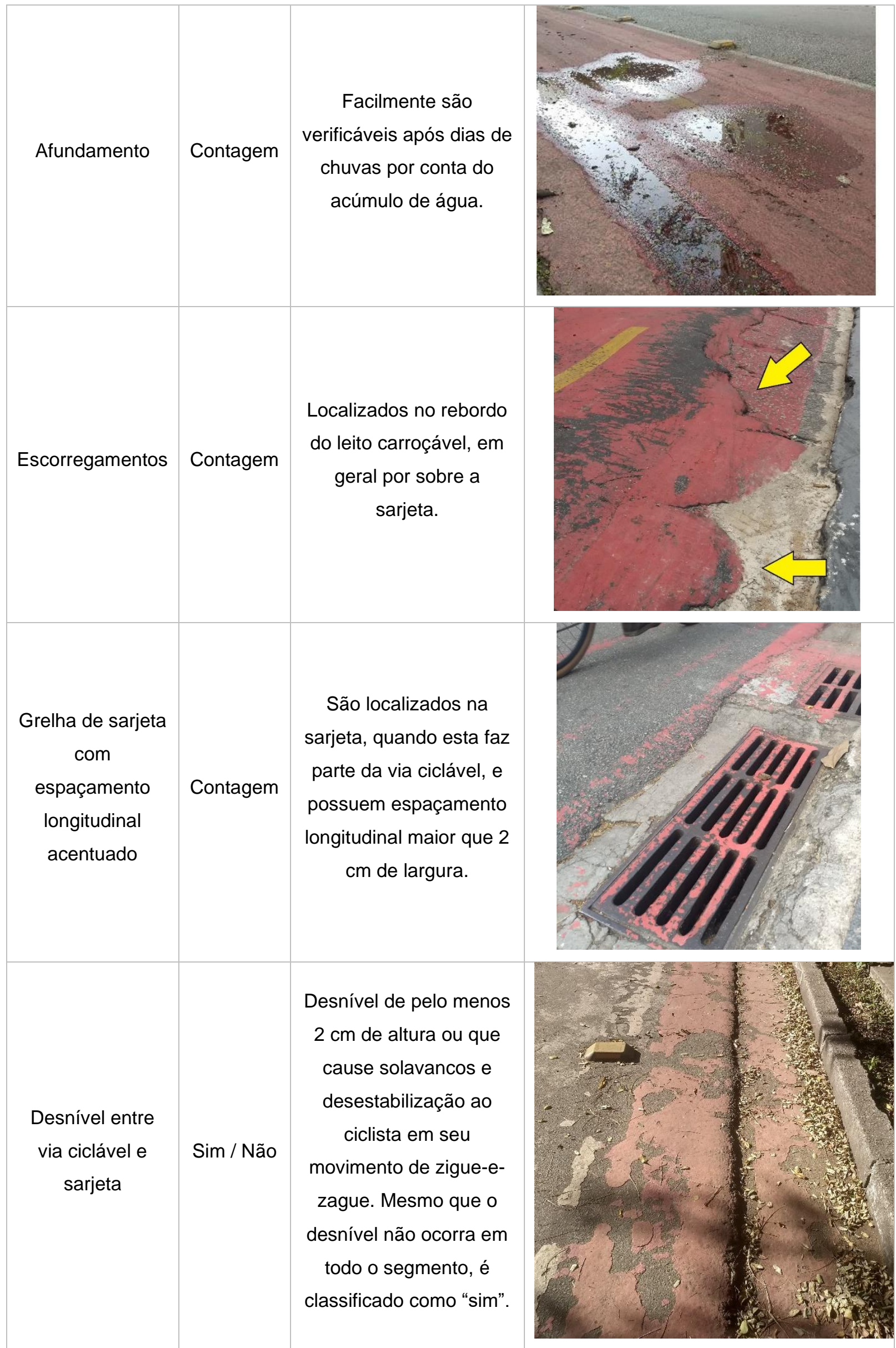




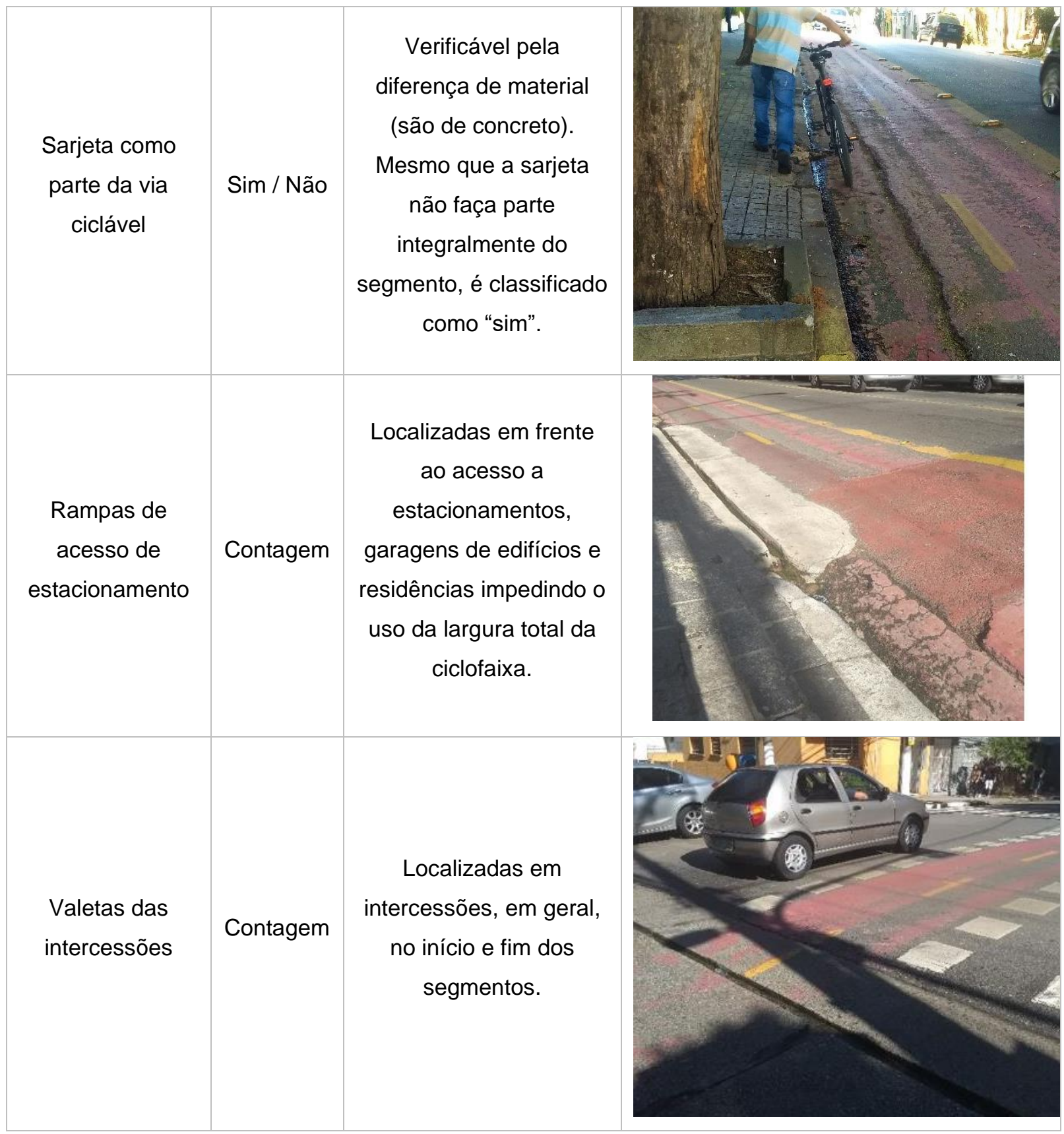




\begin{tabular}{|c|c|c|c|}
\hline \multicolumn{4}{|c|}{ Defeitos de pavimentos de concreto } \\
\hline$\underline{\text { Defeito }}$ & $\underline{\text { Unidade }}$ & Observação & Exemplo \\
\hline Quebras & Contagem & $\begin{array}{l}\text { Podem estar localizadas } \\
\text { nos cantos das placas, } \\
\text { próximo a juntas e estar } \\
\text { relacionadas ao } \\
\text { crescimento de raízes } \\
\text { de árvores. }\end{array}$ & \\
\hline $\begin{array}{l}\text { Esborcinamento } \\
\text { de juntas }\end{array}$ & Contagem & $\begin{array}{l}\text { É contabilizado uma } \\
\text { única vez, mesmo } \\
\text { ocorrendo em duas } \\
\text { placas adjacentes. }\end{array}$ & \\
\hline $\begin{array}{c}\text { Degrau ou } \\
\text { escalonamentos } \\
\text { nas juntas }\end{array}$ & Contagem & $\begin{array}{l}\text { Diferença de nível de, } \\
\text { pelo menos, } 3 \mathrm{~cm} \text { entre } \\
\text { placas que causa } \\
\text { solavancos ou grave } \\
\text { desestabilização ao } \\
\text { ciclista. É contabilizado } \\
\text { uma única vez, mesmo } \\
\text { que ocorra em duas } \\
\text { placas adjacentes. }\end{array}$ & \\
\hline
\end{tabular}




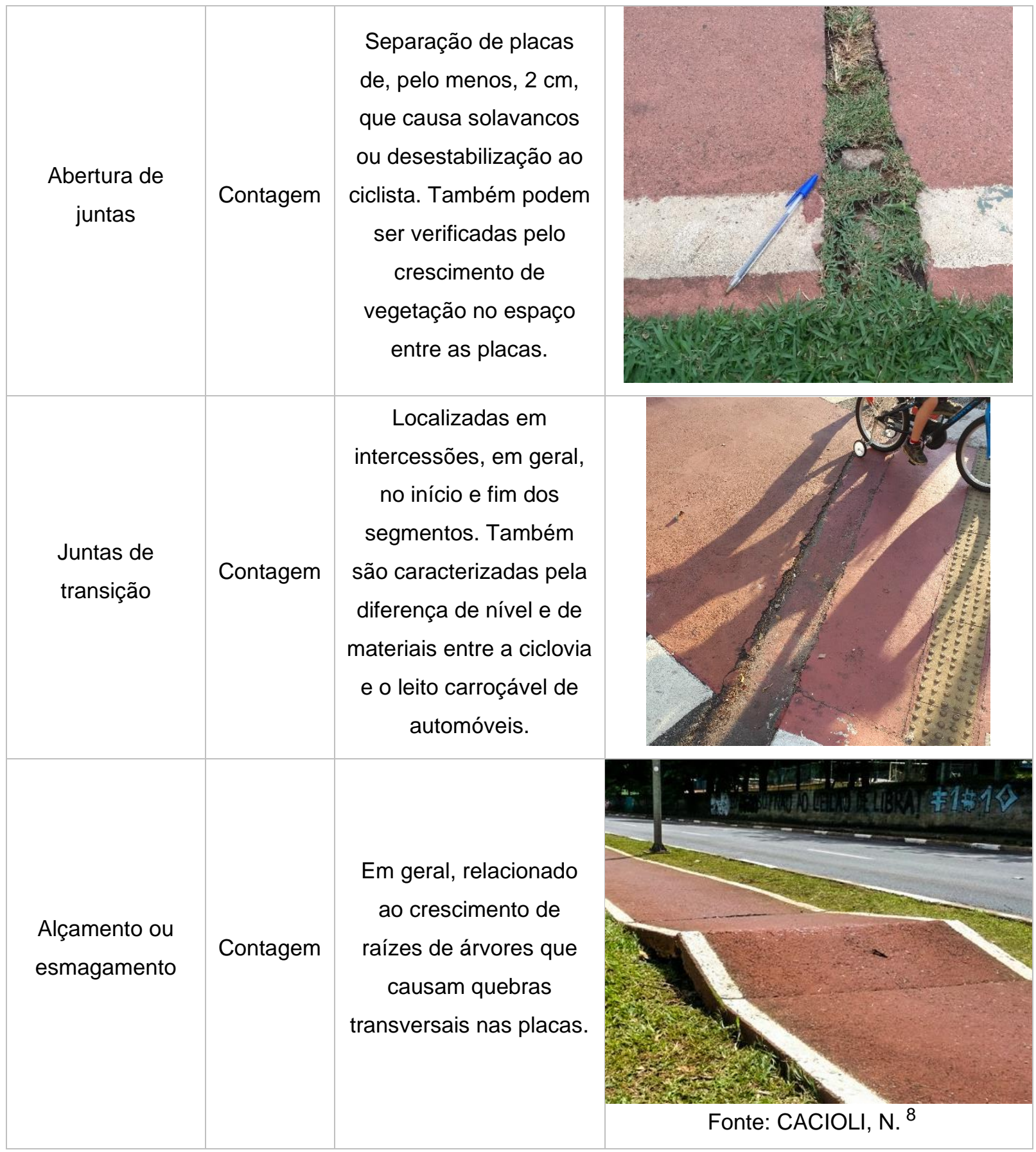

Fonte: o autor

${ }^{8} \mathrm{CACIOLI}$, N., op. cit. 


\subsubsection{4. Índice de Gravidade Global adaptado a Vias Cicláveis - IGGVC}

Como os procedimentos do inventário geral podem vir a demandar excessivo esforço de campo, propõe-se uma metodologia alternativa que também se alinhe com a bibliografia de avaliação de defeitos de pavimentos e diminua o tempo de coleta de dados.

Desta forma, foi selecionada a Ciclovia Faria Lima para que fosse possível aplicar uma metodologia largamente utilizada para a avaliação de defeitos de pavimentos rodoviários, o Índice de Gravidade Global (IGG) descrito por DNIT (2003a), de forma adaptada a vias cicláveis. É importante destacar que esta norma é indicada para pavimentos flexíveis e semi-flexíveis, porém, para que os resultados pudessem ser integrados no objetivo final deste trabalho, foram feitas adaptações a fim de superar estes limites. Dessa forma, é proposto o Índice de Gravidade Global adaptado para Vias Cicláveis (IGGVC).

Para tanto, foi gerado um levantamento local de defeitos e patologias por meio de estações de medição distantes $20 \mathrm{~m}$ entre si ao longo da via, de modo a observar as ocorrências ou não dos defeitos numa área que recobre três metros à frente $\mathrm{e}$ atrás do ponto central da estação. Em outras palavras, o levantamento informa se há ou não cada tipo de defeito em cada estação em trechos longitudinais de 6 metros de extensão. A figura 44 indica a disposição de cada estação na ciclovia selecionada.

Partindo-se destes dados, foi calculada a frequência relativa (fr) por meio do número total de estações $(\mathrm{N})$ em que ocorre um defeito (frequência absoluta, fa), da seguinte forma:

$$
\mathrm{fr}=\left(\frac{\mathrm{fa}}{\mathrm{N}}\right) \cdot 100
$$

O questionário de percepção comparada, subsidiou a definição de fatores de ponderação ( $f p)$ que indicam numericamente (de 0 a 1 ) quais defeitos provocam menos $(\mathrm{f} p=0)$ ou mais $(\mathrm{fp}=1)$ desconforto e insegurança para os ciclistas. Este fator se relaciona com as frequências relativas resultando no Índice de Gravidade Individual adaptado a Vias Cicláveis (IGIVC) para cada defeito de cada segmento, da seguinte forma: 
IGIVC $=\mathrm{fr} . \mathrm{fp}$

Ao final, todos os IGIVC de cada segmento foram somados, configurando o IGGVC.

Figura 44 - Mapas das estações do IGGVC da Ciclovia Faria Lima

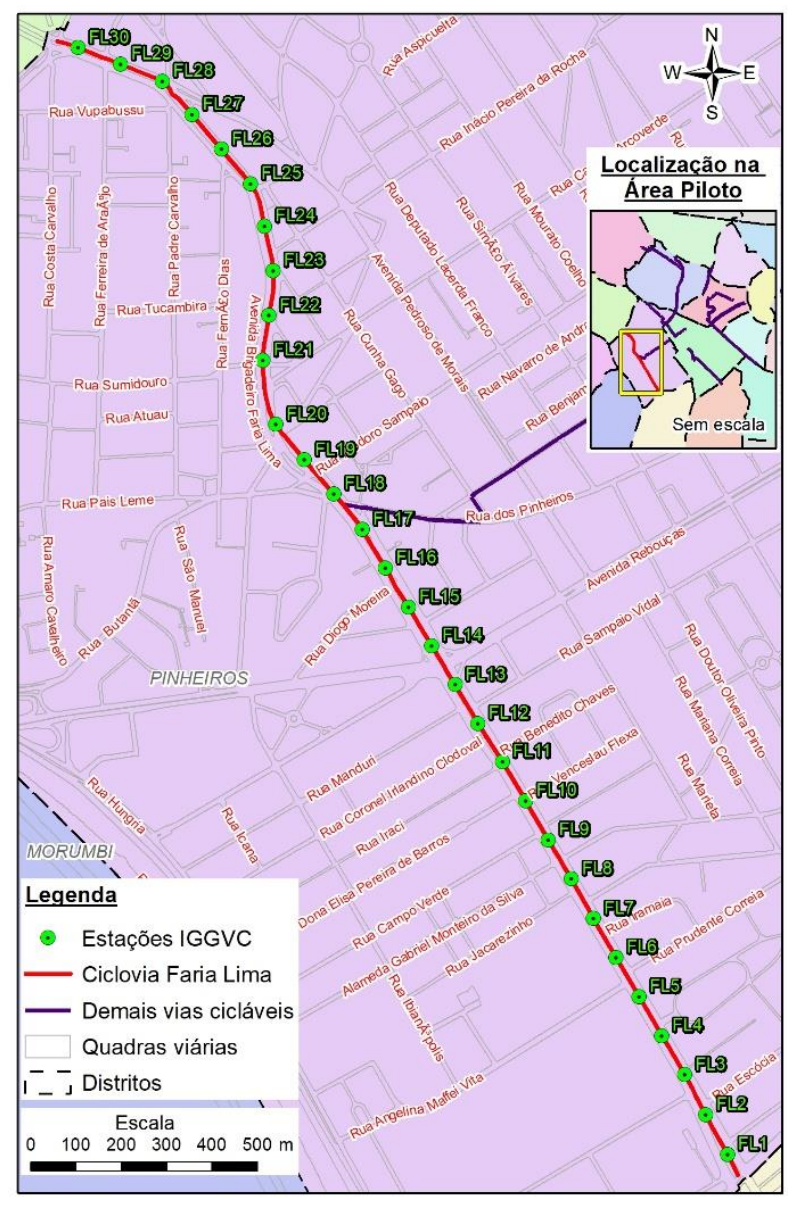

Fonte: Compilação e adaptação do autor ${ }^{9}$

\subsubsection{Indicador de irregularidade longitudinal de vias cicláveis}

Para compor a avaliação da qualidade dos pavimentos de vias cicláveis, foi proposta a incorporação de uma forma de mensuração da aceleração vertical, com o objetivo de se aproximar de uma métrica de irregularidade longitudinal. Para tanto, foi definida a utilização de um acelerômetro de um smartphone, que fez observações da variação da aceleração vertical da bicicleta ao longo dos trajetos da área piloto, o que se aproxima da medida de irregularidade longitudinal. Para a coleta dos dados,

\footnotetext{
${ }^{9}$ Compilação de vetores disponibilizados pela Prefeitura de São Paulo em maior de 2019 por meio do sítio <http://geosampa.prefeitura.sp.gov.br/PaginasPublicas/_SBC.aspx.
} 
foi utilizada uma bicicleta da marca Caloi (modelo 300) com as seguintes especificações:

- Quadro: Alumínio

- Garfo/ Suspensão: Dianteira Rígido

- Guidão: Aço carbono

- Suporte do Guidão: Alumínio com regulagem de inclinação

- Movimento de Direção: Oversize

- Manopla Plástica

- Pedivela: Aço carbono

- Corrente kMC

- Freio Dianteiro: V-Brake de alumínio

- Freio Traseiro: V-Brake de alumínio

- Pedal: Plástico Comfort

- Cubo Dianteiro: Alumínio com Quick Release

- Cubo Traseiro: Alumínio com Quick Release

- Aros: Alumínio parede simples

- Raios: Aço

- Pneus: 26 x 2.00

- Selim: Selle Royal

- Canote do Selim: Alumínio c/suspensão e regulagem

- Abraçadeira do Selim: Alumínio com Quick Release

- Alavanca de Freio: Alumínio para V-Brake

- Alavanca de Câmbio: Shimano Revoshift

- Câmbio Dianteiro: Shimano TZ

- Câmbio Traseiro: Shimano TZ

- Cassete/ Roda Livre: Roda livre 7 velocidades

- Número de Marchas: 21 velocidades

Dentre estas características, se destaca a suspensão dianteira rígida que diminui a interferência de sistemas de amortecimento na medição da aceleração vertical, como recomendam Sayers e Karamihas (1998) para medidores do tipo resposta acoplados em automóveis para mensuração de irregularidade do pavimento. Ao guidão foi acoplado um smartphone Motorola Moto G5 Plus com 
sistema operacional Android 8.1 que coletou os sinais de aceleração vertical por meio do aplicativo Sensor Tracker da Bicasoft Technologies.

Para que não houvesse variações de habilidades ou de massa, foi selecionada apenas uma única ciclista para a coleta dos dados de irregularidade. Foi feita indicação de que percorresse as vias da área de estudo em seu sentido obrigatório de modo que, para as vias bidirecionais, fosse feita duas observações e, para as unidirecionais, apenas uma.

A frequência programada das observações foi de $10 \mathrm{~Hz}$, coletando 10 sinais de aceleração vertical por segundo. Contudo, dada as limitações do acelerômetro foram verificadas coletas de apenas $1 \mathrm{~Hz}$, mas que corresponderam a apenas $0,11 \%$ de toda a amostra, que teve 8,99 observações por segundo de média. O quadro 9 apresenta os totais de observações por frequências de coleta de dados de aceleração vertical.

Quadro 9 - Totais de observações por frequências de aceleração vertical

\begin{tabular}{|c|c|c|}
\hline $\begin{array}{c}\text { Frequência } \\
\text { de coleta }\end{array}$ & $\begin{array}{c}\text { Totais de } \\
\text { observações }\end{array}$ & $\begin{array}{c}\text { Total relativo de } \\
\text { observações }\end{array}$ \\
\hline 1 & 14 & $0,13 \%$ \\
\hline 2 & 36 & $0,34 \%$ \\
\hline 3 & 34 & $0,32 \%$ \\
\hline 4 & 62 & $0,59 \%$ \\
\hline 5 & 50 & $0,47 \%$ \\
\hline 6 & 32 & $0,30 \%$ \\
\hline 7 & 40 & $0,38 \%$ \\
\hline 8 & 1561 & $14,82 \%$ \\
\hline 9 & 6533 & $62,04 \%$ \\
\hline 10 & 2169 & $20,60 \%$ \\
\hline
\end{tabular}

Fonte: o autor

É importante ressaltar que a velocidade da bicicleta não pode ser constante. Esta escolha foi necessária por conta da impossibilidade de isolamento das vias cicláveis no seu contexto urbano: foi inevitável os obstáculos, semáforos, intercessões, pedestres, outros ciclistas. Dessa forma, não foi possível a definição de uma velocidade fixa ou de um intervalo de velocidades para as observações.

Dada as características dos sensores do smartphone, a coleta de informações de localização (pares de coordenadas geográficas) ocorreu de forma não 
sincronizada com os dados de aceleração vertical. Deste modo, para obter apenas um valor de aceleração para cada ponto, cada grupo de acelerações de cada par de coordenadas foi submetido ao cálculo de RMSVA (root mean square vertical acceleration) ou raiz da média quadrática da aceleração vertical, pela equação:

$$
R M S V A=\sqrt{\frac{1}{n} \sum_{i=1}^{N} a_{z i}^{2}}
$$

Onde:

$a_{z}=$ Aceleração vertical $\left(\mathrm{m} / \mathrm{s}^{2}\right)$

$\mathrm{n}=$ número de observações

Com os valores de RMSVA georreferenciados para cada ponto, foi possível relacioná-los com cada um dos segmentos de via. Por conta das oscilações comuns a qualquer sistema de GPS de um smartphone ou mesmo pelas interferências entre o sensor e os satélites (árvores, edifícios, cobertura de nuvens), os pontos não coincidem precisamente em cima da via ciclável. Dessa forma, foi necessária a indicação manual de quais pontos "pertenciam" à quais segmentos de via.

É importante ressaltar que estes ajustes não comprometem a análise aqui proposta, dado que o objetivo final deste trabalho não está focado em obter informações extremamente exatas para pequenas áreas das vias, mas sim, para cada segmento de via num contexto de nível de rede.

\subsection{Avaliação da adequação geométrica das vias cicláveis}

Como o tema de adequação geométrica é bastante vasto e não se pretende esgotar todas as possibilidades de sua análise, foi proposto o Indicador de Adequação Geométrica de Vias Cicláveis (IAGVC). Ele é composto por três eixos principais que, se analisados de forma integrada, sintetizam as principais influências da geometria sobre o conforto e segurança nas vias cicláveis.

O primeiro deles é representado pelos valores coletados em campo das larguras médias de cada segmento de via estudado, a fim de comparação com os valores ideais definidos com base na bibliografia previamente apresentada, como mostra o quadro 10. 
Quadro 10 - Valores de referência do indicador de larguras

\begin{tabular}{|c|c|c|}
\hline Bidirecional & Unidirecional & Indicador de largura \\
\hline Maior que $2,51 \mathrm{~m}$ & Maior que $1,51 \mathrm{~m}$ & Plenamente adequado \\
\hline De 2,26 m a $2,50 \mathrm{~m}$ & De $1,35 \mathrm{~m}$ a $1,50 \mathrm{~m}$ & Parcialmente adequado \\
\hline De 2,01 $\mathrm{m}$ a $2,25 \mathrm{~m}$ & De $1,21 \mathrm{~m}$ a $1,34 \mathrm{~m}$ & Parcialmente inadequado \\
\hline Menor que $2,00 \mathrm{~m}$ & Menor que $1,20 \mathrm{~m}$ & Inadequado \\
\hline
\end{tabular}

Fonte: o autor

O segundo eixo se relaciona às velocidades máximas permitidas nas ruas e avenidas adjacentes às vias cicláveis. Quanto mais alta a velocidade dos veículos automotores, mais dificuldades se impõem para identificação dos ciclistas, para a frenagem ou manobras de desvios, o que aumenta as chances de conflitos e acidentes. Desta forma, a partir da observação das velocidades regulamentares máximas de cidades em que foram aplicadas iniciativas de acalmamento de tráfego e das velocidades máximas já aplicadas em São Paulo, relacionaram-se as velocidades máximas ideais permitidas por automóveis e a tipologia da via ciclável indicada (quadro 11).

Quadro 11 - Valores de referência do indicador de velocidades

\begin{tabular}{|c|c|}
\hline Tipologia & $\begin{array}{c}\text { Velocidade máxima permitida } \\
\text { da via adjacente }\end{array}$ \\
\hline Ciclovia & Adequado até $50 \mathrm{~km} / \mathrm{h}$ \\
\hline Ciclofaixa & Adequado até $40 \mathrm{~km} / \mathrm{h}$ \\
\hline
\end{tabular}

Fonte: o autor

No terceiro eixo, foram incluídos os valores de declividade da via ciclável, que levou em consideração a dificuldade que o ciclista tem em superar rampas e os problemas de aumento de velocidade e de desaceleração nos declives acentuados.

Estes dados relacionados entre si contribuem para a avaliação de segurança da via ciclável. Por exemplo, ciclofaixas em sentido descendente de declividade alta e estreitas situadas ao lado de uma rua com velocidade de automóveis muito alta, apresentam um risco aumentado ao ciclista, dado que este tem um espaço de 
manobra reduzido, o que aumenta a possibilidade de invasão ou desequilíbrio para a via de automóveis.

Para a obtenção dos valores de declividade de cada segmento, primeiramente, em um ambiente SIG, foi gerado um Modelo Digital de Terreno (MDT) da área piloto. Um MDT se define como um grupo ordenado de números que representam a distribuição espacial das elevações sobre um determinado datum em uma paisagem, sendo a unidade de análise (pixel) continente de três informações: $X$ (ordenada), Y (abscissa) e Z (altitude) (Moore et al, 1991). Assim, foi gerada uma matriz espacial que informa a altitude de cada ponto da área piloto. Os insumos utilizados para o processamento foram os vetores das curvas de nível, em escala de 1:1.000 e equidistância de $1 \mathrm{~m}$, do Mapa Digital da Cidade, cedidos pela Secretaria Municipal de Desenvolvimento Urbano da Prefeitura de São Paulo10.

A confecção deste modelo, foi feita utilizando-se a ferramenta Topo to Raster, do módulo Spatial Analyst da plataforma ArcGis $10.5\left(\right.$ Esri $\left.^{\circledR}\right)$, que interpola os valores de altitudes e dados vetoriais das curvas de nível e gera um raster contínuo. Dada a escala de produção dos insumos e da extensão dos segmentos da área piloto, a resolução espacial definida para o MDT foi de 5 metros (obtendo informações de altitude para cada $25 \mathrm{~m}^{2}$ do terreno). A figura 45 apresenta o resultado do MDT gerado para a área piloto.

Em seguida, foi possível calcular as declividades (em porcentagem) de cada segmento a partir do seguinte procedimento:

a) Coleta das altitudes inicial (z1) e final (z2) (por meio da ferramenta Feature Vertices To Points do módulo Data Management Tools e da ferramenta Extract by Points do módulo Spatial Analyst Tools ambos da plataforma ArcGis 10.5);

b) Cálculo do módulo da diferença entre as altitudes inicial (z1) e final (z2) de cada segmento;

c) Cálculo da relação entre esta diferença e a distância horizontal (L) entre cada par de pontos, multiplicada por 100.

$$
\mathrm{D}=\frac{|z 1-z 2|}{\mathrm{L}} .100
$$

\footnotetext{
10 Vetores do Mapa Digital da Cidade (MDC), disponibilizados pela Secretaria Municipal de Desenvolvimento Urbano (SMDU) da Prefeitura de São Paulo em março de 2018 por meio do sítio $<$ http://geosampa.prefeitura.sp.gov.br/PaginasPublicas/_SBC.aspx>.
} 
Figura 45 - Modelo Digital de Terreno da área piloto

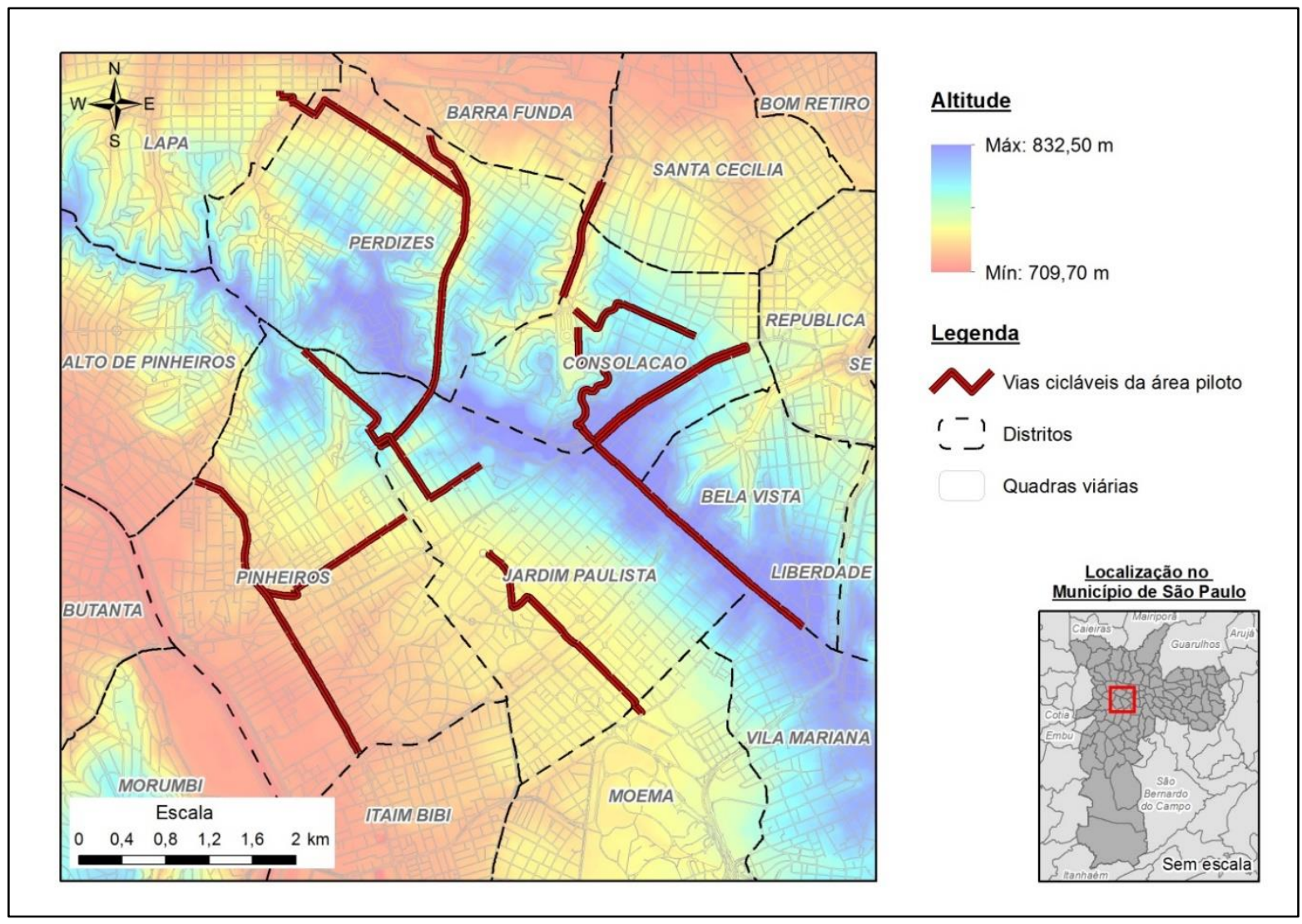

Fonte: material produzido e compilado pelo autor ${ }^{11}$

É importante ressaltar que os resultados não incluem o sentido da via (tendo em mente que o ciclista não necessariamente transita respeitando o sentido obrigatório da rede viária) e os valores adotados para a análise partiram de $0 \%$ (relevo totalmente plano) a declividades superiores.

A classificação dos valores de declividade foi definida como inversamente proporcional aos valores de adequação geométrica, ou seja, quanto maior a inclinação, menos favorável será para o conforto e segurança do ciclista. Foram definidos os intervalos para a classificação com base na observação da amostra de dados da área piloto e na bibliografia previamente apresentada da seguinte forma:

a) de 0 a 2,99\% como segmentos plenamente adequados;

b) de $3 \%$ a 4,99\% como segmento parcialmente adequados;

c) de $5 \%$ a $7,99 \%$ como segmentos parcialmente inadequados;

d) e maior que $8 \%$ como segmentos inadequados.

${ }^{11}$ Compilação dos vetores de vias cicláveis, distritos e municípios disponibilizados pela Prefeitura de São Paulo em março de 2018 por meio do sítio <http://geosampa.prefeitura.sp.gov.br/PaginasPublicas/_SBC.aspx>. 


\section{RESULTADOS}

Os resultados foram obtidos por meio das análises qualitativas e quantitativas das informações geradas e levantados sobre as vias cicláveis da área piloto, sendo dividido em dois tópicos principais: a avaliação da qualidade dos pavimentos e a avaliação da adequação geométrica.

\subsection{Avaliação da qualidade dos pavimentos}

A avaliação de qualidade dos pavimentos foi executada por meio do inventário geral de defeitos e patologias em toda a área piloto e dos resultados do IGGVC exclusivamente para a Ciclovia Faria Lima. Para dar mais robustez aos resultados da identificação de defeitos e patologias, foi aplicado um questionário de percepção comparada que subsidiou a delimitação de fatores de ponderação, que comparou a importância e gravidade de cada tipo de defeito. Paralelamente a estes resultados, foi elaborado um diagnóstico de irregularidade longitudinal, que também avalia o conforto do ciclista por outra abordagem.

\subsubsection{Questionário de percepção comparada e fatores de ponderação}

A coleta de informações de percepção comparada aconteceu durante o mês de fevereiro de 2019, com total de 147 participantes. Deste total, foram excluídas 21 respostas de pessoas que ainda não usavam a bicicleta para se deslocar na cidade (questão 4 do primeiro eixo), restando 126 respostas válidas. Dentre estas, a maior parte dos respondentes se declararam como homens na faixa de 30 a 39 anos de idade, e mesmo nos outros grupos etários, a maioria é masculina (figura 46).

Estes dados obtidos são compatíveis com as afirmações de Callil (2018) ao citar contagens que apontam, com certa frequência, um baixo volume de mulheres ciclistas nas grandes cidades (de $10 \%$ a $20 \%$ ) em relação aos homens, sendo raros os casos de contagem onde se observa uma proporção maior.

Ademais, os resultados do levantamento desta pesquisa também estão de acordo com os dados obtidos na recente Pesquisa de Origem e Destino do Metrô de 
2017, em que apenas aproximadamente 15\% dos ciclistas (por modo principal ou não) são mulheres ${ }^{12}$.

Figura 46 - Gráfico de idades e gênero de ciclistas

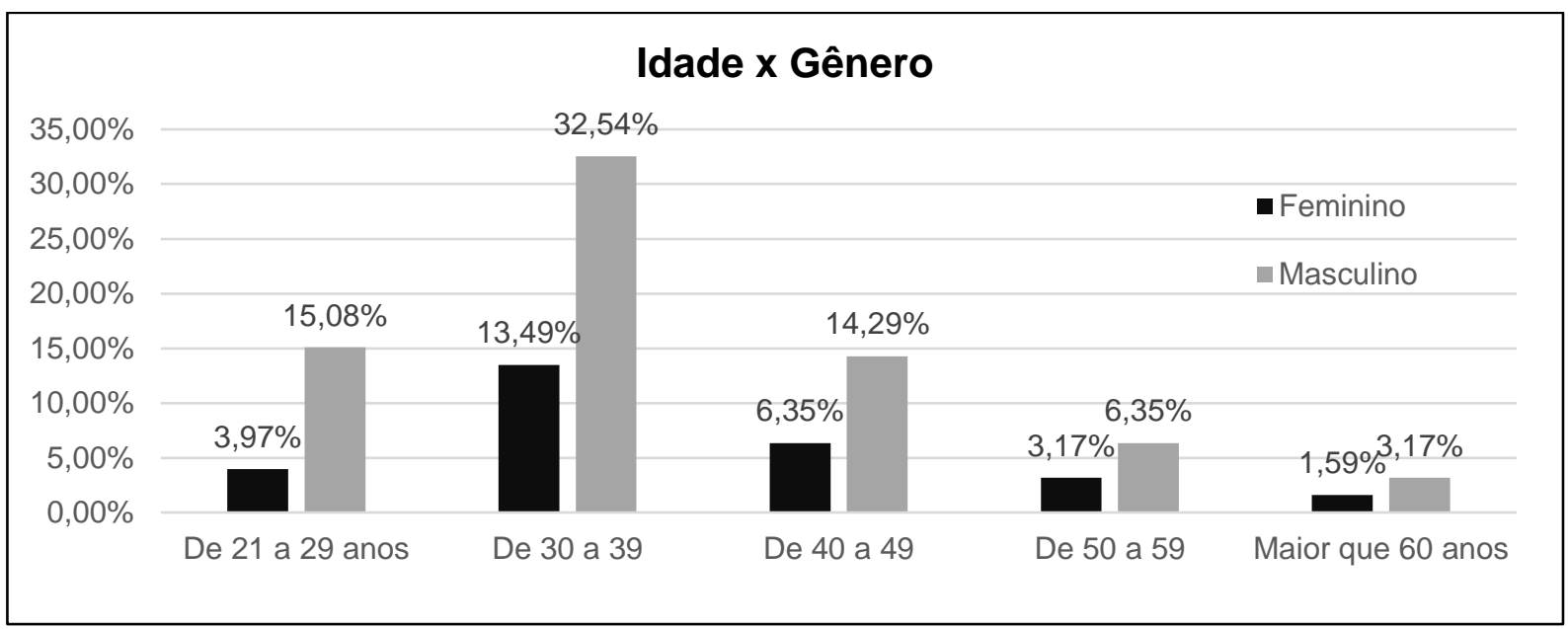

O quadro 12 indica que o motivo de viagem mais frequente constatado foi de trabalho, sendo seguido por ciclistas que usam a bicicleta para todos os tipos de viagem e por motivos de recreação e lazer.

Quadro 12 - Motivo de viagem

\begin{tabular}{|l|c|c|}
\hline $\begin{array}{l}\text { Por qual principal motivo você usa a bicicleta para se deslocar } \\
\text { na cidade? }\end{array}$ & Contagem & Porcentagem \\
\hline A bicicleta é meu principal instrumento de trabalho (ex. Bike entregas) & 1 & $0,79 \%$ \\
\hline Compras / Serviços & 5 & $3,97 \%$ \\
\hline Educação / Escola & 1 & $0,79 \%$ \\
\hline Recreação / Lazer & 38 & $30,16 \%$ \\
\hline Trabalho & 42 & $33,33 \%$ \\
\hline Todos motivos acima & 39 & $30,95 \%$ \\
\hline Total Geral & 126 & $100,00 \%$ \\
\hline
\end{tabular}

A amostra também indica que os ciclistas pesquisados possuem significativa experiência e usam a bicicleta rotineiramente em São Paulo, como mostram o gráfico (figura 47) que relaciona as respostas das questões "Há quanto tempo você usa a bicicleta para se deslocar na cidade?" e "Qual a frequência que você usa a bicicleta para se deslocar para suas principais atividades no dia (ir à escola, ao trabalho, lazer etc.)?”.

12 Número gerado a partir dos dados brutos fornecidos pelo Metrô de São Paulo. Disponível em $<$ http://www.metro.sp.gov.br/pesquisa-od/arquivos/Pesquisa-Origem-Destino-2017-Banco-Dados.zip> Acesso em 03 de agosto de 2019. 
Figura 47 - Gráfico de rotina e histórico de uso de ciclistas

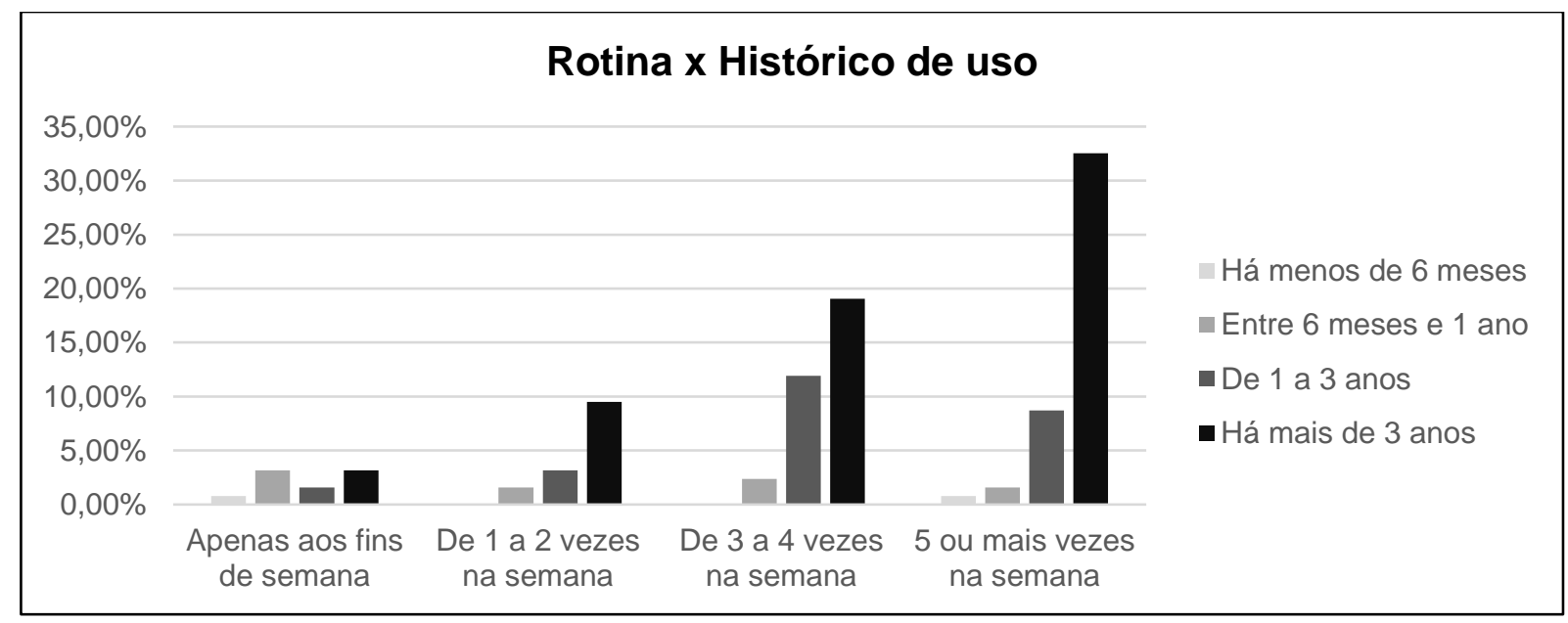

As respostas coletadas sobre a percepção de conforto e segurança em relação aos defeitos e as patologias são resumidas no quadro 13.

Quadro 13 - Resumo estatístico do questionário de percepção comparada

\begin{tabular}{|c|c|c|c|c|c|}
\hline Defeito ou Patologia & Média & Mediana & Moda & $\begin{array}{c}\text { Desvio } \\
\text { padrão }\end{array}$ & Variância \\
\hline Fissuras isoladas & 2,73 & 3 & 3 & 1,29 & 1,65 \\
\hline Fissuras em blocos & 3,76 & 4 & 5 & 1,04 & 1,08 \\
\hline Quebras & 4,52 & 5 & 5 & 0,79 & 0,62 \\
\hline Buracos & 4,73 & 5 & 5 & 0,59 & 0,34 \\
\hline $\begin{array}{c}\text { Esborcinamento (desgaste) de } \\
\text { juntas }\end{array}$ & 3,17 & 3 & 3 & 1,25 & 1,56 \\
\hline $\begin{array}{c}\text { Degrau ou escalonamento de } \\
\text { juntas }\end{array}$ & 4,71 & 5 & 5 & 0,64 & 0,41 \\
\hline Abertura de juntas & 4,03 & 4 & 5 & 1,01 & 1,02 \\
\hline Alçamento de placas & 4,23 & 5 & 5 & 0,99 & 0,98 \\
\hline Desgaste da cor do pavimento & 2,36 & 2 & 2 & 1,15 & 1,32 \\
\hline Remendos & 2,88 & 3 & 3 & 1,12 & 1,26 \\
\hline $\begin{array}{c}\text { Afundamento (depressões ou } \\
\text { ondulações) }\end{array}$ & 3,81 & 4 & 4 & 1,02 & 1,04 \\
\hline Escorregamento & 4,10 & 4 & 5 & 0,98 & 0,97 \\
\hline Juntas de transição & 3,42 & 3 & 3 & 1,05 & 1,11 \\
\hline Valetas nas intercessões & 3,65 & 4 & 3 & 1,03 & 1,06 \\
\hline $\begin{array}{c}\text { Desnível entre via ciclável e } \\
\text { sarjeta }\end{array}$ & 4,69 & 5 & 5 & 0,61 & 0,38 \\
\hline Sarjeta como parte da via ciclável & 4,44 & 5 & 5 & 0,84 & 0,71 \\
\hline $\begin{array}{c}\text { Grelha de sarjeta com espaço } \\
\text { longitudinal acentuado }\end{array}$ & 4,56 & 5 & 5 & 0,78 & 0,62 \\
\hline $\begin{array}{c}\text { Tampas de poços de visita (PV) } \\
\text { ou Bocas de lobo }\end{array}$ & 4,03 & 4 & 5 & 1,02 & 1,04 \\
\hline Rampas de estacionamento & 4,02 & 4 & 5 & 1,07 & 1,15 \\
\hline
\end{tabular}


Como a pesquisa foi desenvolvida por meio de um questionário Tipo Likert, foram utilizados os resultados da mediana para a compreensão da tendência central como base para a determinação dos fatores de ponderação. Desta forma, os valores da mediana, que variam de 1 a 5 , foram transferidos para uma escala de 0 a 1 como aponta o quadro 14.

Quadro 14 - Fatores de ponderação baseados na mediana da amostra

\begin{tabular}{|c|c|}
\hline Defeito ou Patologia & $\begin{array}{c}\text { Fator de } \\
\text { ponderação }\end{array}$ \\
\hline Fissuras isoladas & 0,60 \\
\hline Fissuras em blocos & 0,80 \\
\hline Quebras & 1,00 \\
\hline Buracos & 1,00 \\
\hline $\begin{array}{c}\text { Esborcinamento (desgaste) de } \\
\text { juntas }\end{array}$ & 0,60 \\
\hline $\begin{array}{c}\text { Degrau ou escalonamento de } \\
\text { juntas }\end{array}$ & 1,00 \\
\hline Abertura de juntas & 0,80 \\
\hline Alçamento de placas & 1,00 \\
\hline Desgaste da cor do pavimento & 0,40 \\
\hline Remendos & 0,60 \\
\hline $\begin{array}{c}\text { Afundamento (depressões ou } \\
\text { ondulações) }\end{array}$ & 0,80 \\
\hline Escorregamento & 0,80 \\
\hline Juntas de transição & 0,60 \\
\hline Valetas nas intercessões & 0,80 \\
\hline $\begin{array}{c}\text { Desnível entre via ciclável e } \\
\text { sarjeta }\end{array}$ & 1,00 \\
\hline Sarjeta como parte da via ciclável & 1,00 \\
\hline $\begin{array}{c}\text { Grelha de sarjeta com espaço } \\
\text { longitudinal acentuado }\end{array}$ & 1,00 \\
\hline $\begin{array}{c}\text { Tampas de poços de visita (PV) } \\
\text { ou Bocas de lobo }\end{array}$ & 0,80 \\
\hline Rampas de estacionamento & 0,80 \\
\hline
\end{tabular}

Para avaliar a consistência dos resultados do questionário foi utilizado o coeficiente de variância da mediana, que possibilitou segmentar as respostas relativas em três classes, indicadas no quadro 15. 
Quadro 15 - Segmentação dos fatores de ponderação pela variância da mediana

\begin{tabular}{|c|c|c|c|}
\hline Defeito ou Patologia & $\begin{array}{c}\text { Coeficiente de } \\
\text { Variação (\%) }\end{array}$ & Grupos & $\begin{array}{c}\text { Fator de } \\
\text { ponderação }\end{array}$ \\
\hline Buracos & $12,37 \%$ & $\mathrm{~A}$ & 1,00 \\
\hline $\begin{array}{c}\text { Desnível entre via ciclável e } \\
\text { sarjeta }\end{array}$ & $13,06 \%$ & $\mathrm{~A}$ & 1,00 \\
\hline $\begin{array}{c}\text { Degrau ou escalonamento de } \\
\text { juntas }\end{array}$ & $13,64 \%$ & $\mathrm{~A}$ & 1,00 \\
\hline $\begin{array}{c}\text { Grelha de sarjeta com espaço } \\
\text { longitudinal acentuado }\end{array}$ & $17,20 \%$ & $\mathrm{~A}$ & 1,00 \\
\hline Quebras & $17,43 \%$ & $\mathrm{~A}$ & 1,00 \\
\hline Sarjeta como parte da via ciclável & $19,00 \%$ & $\mathrm{~A}$ & 1,00 \\
\hline Alçamento de placas & $23,39 \%$ & $\mathrm{~B}$ & 1,00 \\
\hline Escorregamento & $24,01 \%$ & $\mathrm{~B}$ & 0,80 \\
\hline Abertura de juntas & $25,09 \%$ & $\mathrm{~B}$ & 0,80 \\
\hline $\begin{array}{c}\text { Tampas de poços de visita (PV) } \\
\text { ou Bocas de lobo }\end{array}$ & $25,28 \%$ & $\mathrm{~B}$ & 0,80 \\
\hline Afundamento (depressões ou \\
ondulações) & $26,71 \%$ & $\mathrm{~B}$ & 0,80 \\
\hline Rampas de estacionamento & $26,72 \%$ & $\mathrm{~B}$ & 0,80 \\
\hline Fissuras em blocos & $27,61 \%$ & $\mathrm{~B}$ & 0,80 \\
\hline Valetas nas intercessões & $28,22 \%$ & $\mathrm{~B}$ & 0,80 \\
\hline Juntas de transição & $30,80 \%$ & $\mathrm{C}$ & 0,60 \\
\hline Remendos & $38,93 \%$ & $\mathrm{C}$ & 0,60 \\
\hline Esborcinamento (desgaste) de & $39,49 \%$ & $\mathrm{C}$ & 0,60 \\
\hline juntas & $47,11 \%$ & $\mathrm{C}$ & 0,60 \\
\hline Fissuras isoladas & $48,73 \%$ & $\mathrm{C}$ & 0,40 \\
\hline Desgaste da cor do pavimento & & \\
\hline
\end{tabular}

O grupo A (até 19\%) mostra que não houve variação significativa nas respostas de percepção a segurança e conforto relacionada aos defeitos mais graves (de fator de ponderação 1), como buracos, desnível entre via ciclável e sarjeta, degrau ou escalonamento de juntas, grelha de sarjeta com espaço longitudinal acentuado, quebras e sarjeta como parte da via ciclável.

O grupo B (de 23,29\% a 28,22\%) indica uma variação intermediária nas respostas do questionário, com destaque para valetas nas intercessões e rampas de estacionamento que não são defeitos por si sós, mas externalidades de outros sistemas de infraestrutura, o que pode gerar dúvida na avaliação do ciclista quanto a sua adequação ou possibilidade de manutenção.

O grupo C (mais que 30,88\%) indica os defeitos que receberam notas de percepção mais diferentes entre si: juntas de transição, remendos, esborcinamento (desgaste) de juntas, fissuras isoladas, e desgaste da cor do pavimento. Em outras 
palavras, houve pouco consenso sobre como estes defeitos afetam o conforto e a segurança dos ciclistas.

Numa avaliação crítica do questionário, isto pode ter ocorrido pela falta de entendimento do texto ou das imagens propostas aos ciclistas, sobretudo nos defeitos de esborcinamento (por ser um termo bastante técnico e não muito comum no vocabulário informal), juntas de transição e remendos (por não serem exclusivamente problemas, mas uma solução de adequação ou manutenção que podem evoluir para defeitos de forma mais rápida e severa que o pavimento como um todo).

\subsubsection{Inventário geral e diagnóstico de defeitos e patologias}

O inventário geral de defeitos e patologias foi elaborado por meio de vistorias a pé ocorridas em fevereiro de 2019 em todos os 156 segmentos de via ciclável da área piloto. Os dados brutos deste levantamento possibilitam a caracterização das vias cicláveis quanto à ocorrência de defeitos e sua distribuição espacial na área piloto.

Foram identificados 2.658 defeitos, sendo as fissuras isoladas o elemento mais encontrado e os alçamentos de placas o menos frequente. $O$ quadro 16 apresenta os valores absolutos de contagens de cada tipo de defeito identificado para cada via.

Para os defeitos exclusivos de pavimentos rígidos, as juntas de transição foram as mais frequentes (120 ocorrências), o que pode ser explicado pelo fato de serem uma proposta de solução para as intercessões, ou seja, ocorrem em quase todos os cruzamentos entre ciclovias e ruas.

Os alçamentos ou esmagamentos foram os defeitos exclusivos de pavimentos rígidos menos frequentes (6 ocorrências). Isto se explica por serem defeitos que são originados por intensas e frequentes pressões horizontais (mais relacionados com veículos grande massa) ou pela evolução de quebras (como é o caso da Ciclovia Sumaré, em que há o crescimento de raízes de árvores lindeiras à via).

As fissuras em blocos são os defeitos exclusivos de pavimentos asfálticos que mais ocorreram (137 ocorrências), o que denota um grau significativo de deterioração da rede, enquanto as valetas nas intercessões foram os que menos ocorreram (16 ocorrências). Assim como as juntas de transição, as valetas são 
soluções para outras estruturas (no caso, escoamento de água) e seria muito difícil projetar ciclofaixas sem a necessidade de inseri-las. Contudo, a baixa incidência da deste defeito indica uma boa concepção do projeto de vias e suas rotas. Já para os defeitos comuns a pavimentos rígidos e asfálticos, as fissuras isoladas foram as mais frequentes (789 ocorrências) enquanto os buracos ocorreram em menor número (146 ocorrências).

Quadro 16 - Defeitos e patologias identificados pelo Inventário geral

\begin{tabular}{|c|c|c|c|c|c|c|c|c|c|c|c|c|}
\hline DEFEITO CICLÁVEL & 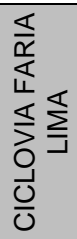 & 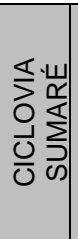 & 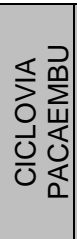 & 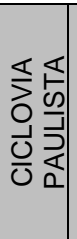 & 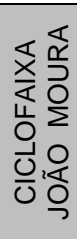 & 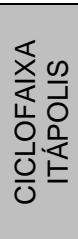 & 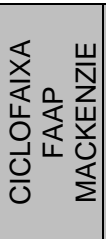 & 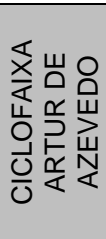 & 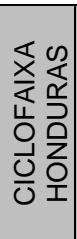 & 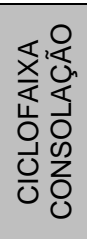 & 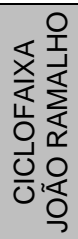 & $\stackrel{\frac{1}{5}}{\stackrel{5}{\circ}}$ \\
\hline Quebras & 14 & 29 & 3 & 38 & $\mathrm{~N} / \mathrm{A}$ & $\mathrm{N} / \mathrm{A}$ & $\mathrm{N} / \mathrm{A}$ & $\mathrm{N} / \mathrm{A}$ & $\mathrm{N} / \mathrm{A}$ & $\mathrm{N} / \mathrm{A}$ & $\mathrm{N} / \mathrm{A}$ & 84 \\
\hline Esborcinamento de juntas & 6 & 12 & 4 & 22 & $\mathrm{~N} / \mathrm{A}$ & $\mathrm{N} / \mathrm{A}$ & $\mathrm{N} / \mathrm{A}$ & $\mathrm{N} / \mathrm{A}$ & $\mathrm{N} / \mathrm{A}$ & $\mathrm{N} / \mathrm{A}$ & $\mathrm{N} / \mathrm{A}$ & 44 \\
\hline $\begin{array}{c}\text { Degrau ou Escalonamento } \\
\text { nas juntas }\end{array}$ & 12 & 50 & 3 & 0 & $\mathrm{~N} / \mathrm{A}$ & $N / A$ & $N / A$ & $N / A$ & $\mathrm{~N} / \mathrm{A}$ & $N / A$ & $\mathrm{~N} / \mathrm{A}$ & 65 \\
\hline Abertura de Juntas & 3 & 79 & 1 & 0 & $\mathrm{~N} / \mathrm{A}$ & $\mathrm{N} / \mathrm{A}$ & $\mathrm{N} / \mathrm{A}$ & $\mathrm{N} / \mathrm{A}$ & $\mathrm{N} / \mathrm{A}$ & $\mathrm{N} / \mathrm{A}$ & $\mathrm{N} / \mathrm{A}$ & 83 \\
\hline $\begin{array}{l}\text { Alçamento ou } \\
\text { esmagamento }\end{array}$ & 0 & 6 & 0 & 0 & $\mathrm{~N} / \mathrm{A}$ & $\mathrm{N} / \mathrm{A}$ & $N / A$ & $\mathrm{~N} / \mathrm{A}$ & $N / A$ & $N / A$ & $\mathrm{~N} / \mathrm{A}$ & 6 \\
\hline Juntas de Transição & 48 & 23 & 0 & 49 & $\mathrm{~N} / \mathrm{A}$ & $N / A$ & $\mathrm{~N} / \mathrm{A}$ & $\mathrm{N} / \mathrm{A}$ & $\mathrm{N} / \mathrm{A}$ & $N / A$ & $\mathrm{~N} / \mathrm{A}$ & 120 \\
\hline Fissuras em Blocos & $\mathrm{N} / \mathrm{A}$ & $\mathrm{N} / \mathrm{A}$ & $\mathrm{N} / \mathrm{A}$ & $\mathrm{N} / \mathrm{A}$ & 35 & 43 & 13 & 0 & 14 & 3 & 29 & 137 \\
\hline Afundamento & $\mathrm{N} / \mathrm{A}$ & $\mathrm{N} / \mathrm{A}$ & $\mathrm{N} / \mathrm{A}$ & $\mathrm{N} / \mathrm{A}$ & 20 & 7 & 1 & 3 & 14 & 1 & 21 & 67 \\
\hline Escorregamento & $\mathrm{N} / \mathrm{A}$ & $\mathrm{N} / \mathrm{A}$ & $\mathrm{N} / \mathrm{A}$ & $\mathrm{N} / \mathrm{A}$ & 0 & 0 & 1 & 1 & 6 & 9 & 1 & 18 \\
\hline $\begin{array}{c}\text { Grelha de sarjeta com } \\
\text { espaçamento longitudinal } \\
\text { acentuado }\end{array}$ & $N / A$ & $N / A$ & $\mathrm{~N} / \mathrm{A}$ & $\mathrm{N} / \mathrm{A}$ & 5 & 0 & 0 & 2 & 5 & 15 & 2 & 29 \\
\hline $\begin{array}{c}\text { Desnível entre via ciclável } \\
\text { e Sarjeta }\end{array}$ & $N / A$ & $N / A$ & $\mathrm{~N} / \mathrm{A}$ & $N / A$ & 12 & 0 & 4 & 6 & 2 & 1 & 4 & 29 \\
\hline $\begin{array}{c}\text { Sarjeta como parte da via } \\
\text { ciclável }\end{array}$ & $\mathrm{N} / \mathrm{A}$ & $N / A$ & $\mathrm{~N} / \mathrm{A}$ & $N / A$ & 19 & 5 & 8 & 14 & 15 & 14 & 20 & 95 \\
\hline $\begin{array}{c}\text { Rampas de acesso de } \\
\text { estacionamento }\end{array}$ & $\mathrm{N} / \mathrm{A}$ & $N / A$ & $N / A$ & $N / A$ & 13 & 0 & 6 & 7 & 2 & 0 & 4 & 32 \\
\hline Valetas nas intercessões & $\mathrm{N} / \mathrm{A}$ & $\mathrm{N} / \mathrm{A}$ & $\mathrm{N} / \mathrm{A}$ & $\mathrm{N} / \mathrm{A}$ & 5 & 0 & 0 & 6 & 0 & 0 & 5 & 16 \\
\hline Fissuras isoladas & 80 & 114 & 50 & 105 & 78 & 38 & 36 & 8 & 66 & 97 & 117 & 789 \\
\hline Buracos & 16 & 5 & 3 & 15 & 14 & 14 & 8 & 2 & 21 & 28 & 20 & 146 \\
\hline $\begin{array}{c}\text { Desgaste da pintura } \\
\text { superficial }\end{array}$ & 12 & 4 & 0 & 0 & 37 & 8 & 12 & 37 & 25 & 6 & 18 & 159 \\
\hline Remendos & 13 & 19 & 0 & 4 & 56 & 20 & 11 & 12 & 23 & 13 & 49 & 220 \\
\hline $\begin{array}{c}\text { Tampas de Poços de visita } \\
\text { em aço ou concreto (PV) } \\
\text { ou Bocas de Lobo }\end{array}$ & 68 & 49 & 17 & 212 & 17 & 6 & 16 & 10 & 17 & 85 & 22 & 519 \\
\hline Total & 272 & 390 & 81 & 445 & 311 & 141 & 116 & 108 & 210 & 272 & 312 & 2658 \\
\hline
\end{tabular}

Como as vias e os segmentos são diferentes, só é possível analisar a ocorrência espacial de defeitos se os relacionar com as extensões das vias. A figura 48 apresenta o índice do total de defeitos identificados em cada via por suas extensões (def/km). 
Figura 48 - Índice de defeitos por extensão de via

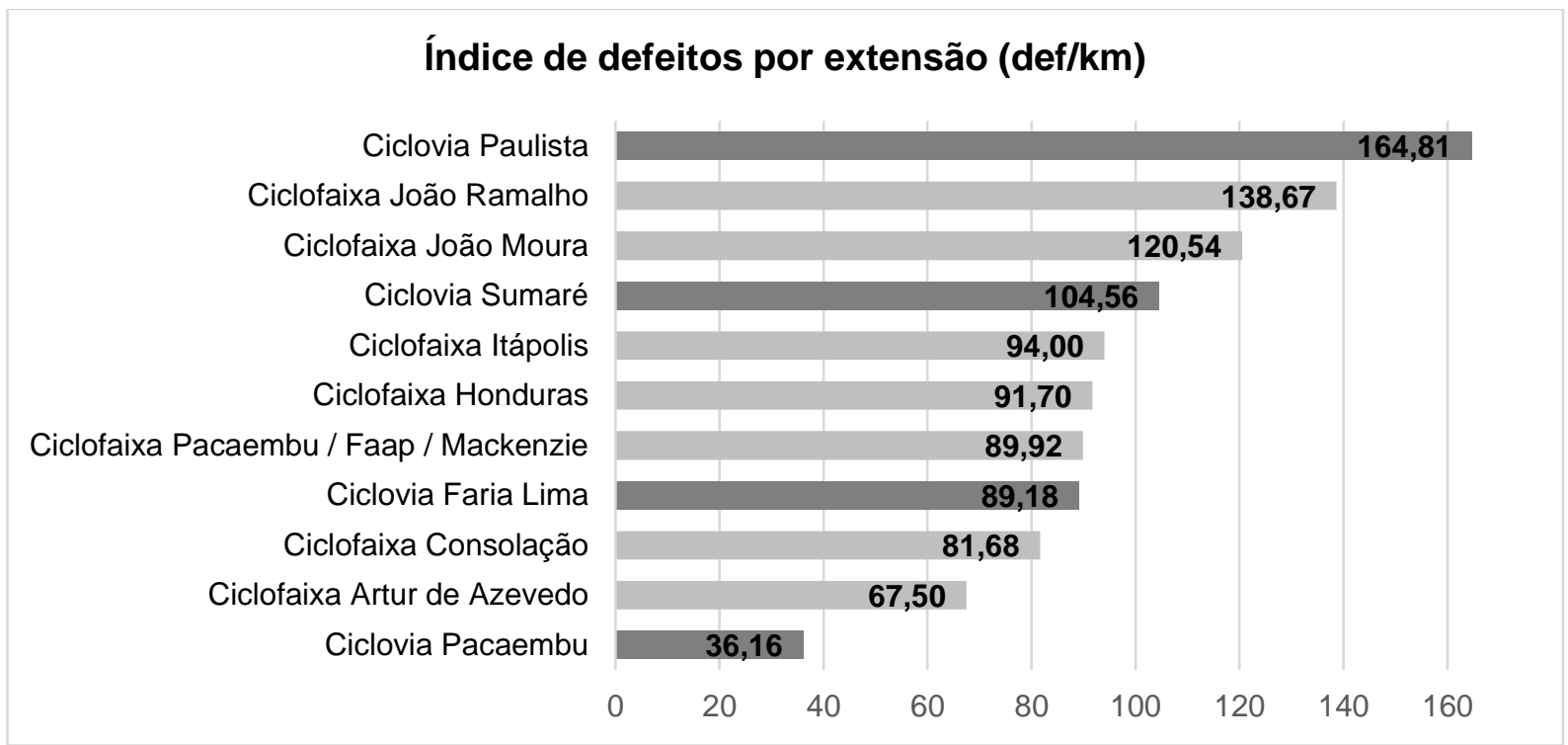

Em se tratando apenas da ocorrência dos defeitos (desconsiderando a diferença de gravidade entre eles), a Ciclovia Pacaembu apresenta a melhor situação dentre vias na área piloto: possui o menor índice (36,16 def/km) e o menor total de defeitos (81).

Diferentemente do esperado, não há uma relação clara entre o diagnóstico de defeitos e a tipologia da via, ou seja, ciclovias e ciclofaixas possuem índices altos e baixos. Este não é exatamente um resultado esperado, dado que a operação das ciclovias envolve nenhuma ou poucas interferências dos modos motorizados, o que diminuiria o desgaste do pavimento.

Outro resultado não esperado, em relação às vistorias preliminares, é o índice da Ciclovia Paulista $(164,81 \mathrm{def} / \mathrm{km})$. Isto se explica pelo alto número de Tampas de poços de visita em aço ou concreto (PV) ou Bocas de Lobo identificados: total de 212 ou $40,8 \%$ de todas as ocorrências deste tipo de defeito.

A figura 49 apresenta a disposição espacial do índice de defeitos por extensões para cada segmento. 
Figura 49 - Mapa de defeitos por extensão para segmentos

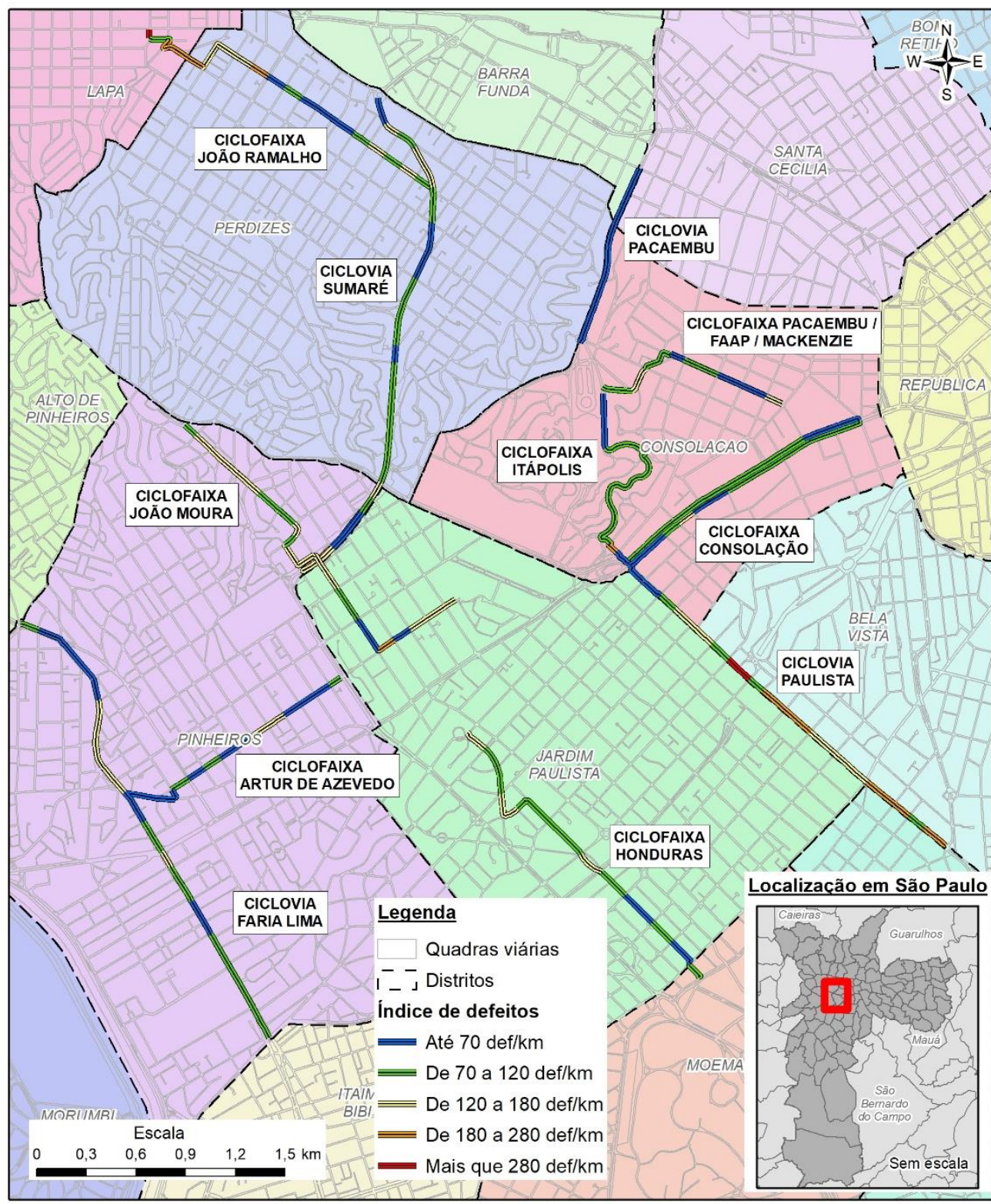

Fonte: produzido e compilado pelo autor ${ }^{13}$

Neste exemplo, fica claro que considerar apenas a existência de uma patologia não necessariamente afeta a qualidade da via ciclável, sendo muito importante a incorporação de algum tipo de ponderação entre os defeitos.

${ }^{13}$ Compilação dos vetores de vias cicláveis, quadras viárias, distritos e municípios disponibilizados pela Prefeitura de São Paulo em março de 2018 por meio do sítio <http://geosampa.prefeitura.sp.gov.br/PaginasPublicas/_SBC.aspx>. 


\subsubsection{Levantamento local de defeitos e patologias e IGGVC}

Como explicitado anteriormente, muitos índices de qualidade de rodovias já são padronizados e frequentemente usados pelas agências de transporte em todo $o$ mundo. Como este cenário é diferente para as vias cicláveis, que não possuem procedimentos tão bem definidos e aceitos, neste trabalho foi proposta uma releitura de um índice utilizado para a avaliação da qualidade de pavimentos asfálticos: o Índice de Gravidade Global adaptado a Vias Cicláveis (IGGVC). Desta forma, foram levantados os defeitos pré-definidos em estações distantes $20 \mathrm{~m}$ entre si, que foram relacionados com os fatores de ponderação oriundos do questionário de percepção comparada, aproximando-se da metodologia preconizada por DNIT (2003a).

Quadro 17 - Resultados do levantamento local para a Ciclovia Faria Lima

\begin{tabular}{|c|c|c|c|c|c|c|c|c|c|c|c|}
\hline Defeito & 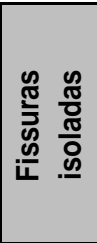 & 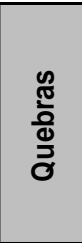 & 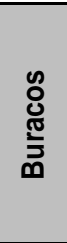 & 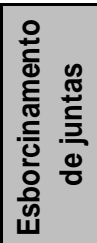 & 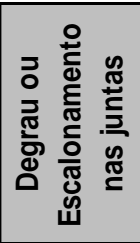 & 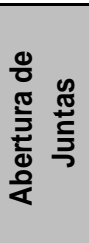 & 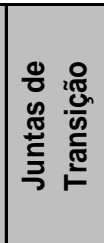 & 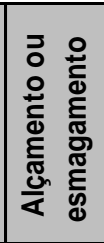 & 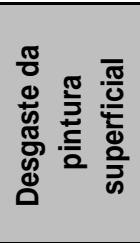 & 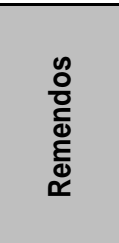 & 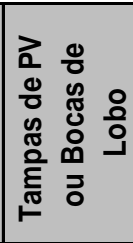 \\
\hline 1 & $X$ & - & - & - & - & - & - & - & 0 & - & - \\
\hline 2 & $x$ & - & - & - & $x$ & - & - & - & 0 & $x$ & $x$ \\
\hline 3 & $X$ & - & - & - & - & - & - & - & 0 & - & - \\
\hline 4 & $x$ & - & $x$ & - & - & - & - & - & 0 & - & - \\
\hline 5 & $X$ & $X$ & - & - & - & - & - & - & 0 & - & - \\
\hline 6 & $x$ & - & - & - & - & - & - & - & 0 & - & - \\
\hline 7 & - & - & - & - & - & - & - & - & 0 & - & - \\
\hline 8 & $x$ & - & - & - & - & - & - & - & 0 & - & - \\
\hline 9 & - & - & - & - & - & - & - & - & 0 & - & - \\
\hline 10 & $x$ & - & - & $x$ & - & - & - & - & 0 & - & - \\
\hline 11 & - & - & - & - & - & - & - & - & 0 & - & $X$ \\
\hline 12 & - & $x$ & - & $x$ & $x$ & - & $x$ & - & 1 & - & - \\
\hline 13 & $x$ & - & - & - & - & - & - & - & 1 & - & $x$ \\
\hline 14 & - & - & - & - & - & $x$ & - & - & 1 & - & - \\
\hline 15 & - & $x$ & - & $X$ & $x$ & $x$ & - & - & 1 & - & - \\
\hline 16 & $x$ & - & - & - & - & - & $x$ & - & 1 & - & - \\
\hline 17 & - & - & - & - & $X$ & - & - & - & 1 & $X$ & - \\
\hline 18 & $x$ & - & - & - & - & - & - & - & 2 & $X$ & - \\
\hline 19 & $X$ & - & - & - & - & - & - & - & 2 & - & - \\
\hline 20 & $x$ & - & $x$ & - & - & - & - & - & 2 & - & - \\
\hline 21 & $x$ & - & - & - & - & - & - & - & 1 & - & $x$ \\
\hline 22 & $x$ & - & - & - & - & - & - & - & 1 & - & $x$ \\
\hline 23 & $X$ & - & - & - & - & - & - & - & 1 & - & - \\
\hline 24 & $x$ & - & - & - & - & - & - & - & 0 & - & - \\
\hline 25 & $x$ & - & - & - & - & - & - & - & 0 & - & $x$ \\
\hline 26 & - & - & - & - & - & - & - & - & 1 & - & - \\
\hline 27 & $X$ & - & - & - & - & - & - & - & 1 & - & - \\
\hline 28 & - & - & - & - & - & - & $x$ & - & 0 & - & - \\
\hline 29 & - & - & - & - & - & - & - & - & 0 & - & - \\
\hline 30 & $x$ & $x$ & - & - & $x$ & - & - & - & 0 & $x$ & $x$ \\
\hline$\overline{F A}$ & 20 & 4 & 2 & 3 & 5 & 2 & 3 & $\overline{0}$ & 17 & 4 & 7 \\
\hline $\mathbf{N}$ & 30 & 30 & 30 & 30 & 30 & 30 & 30 & 30 & 30 & 30 & 30 \\
\hline FR & 66,7 & 13,3 & 6,7 & 10,0 & 16,7 & 6,7 & 10,0 & 0,0 & 56,7 & 13,3 & 23,3 \\
\hline FP & 0,6 & 1,0 & 1,0 & 0,6 & 1,0 & 0,8 & 0,6 & 1,0 & 0,4 & 0,6 & 0,8 \\
\hline IGI & 40,0 & 13,3 & 6,7 & 6,0 & 16,7 & 5,3 & 6,0 & 0,0 & 22,7 & 8,0 & 18,7 \\
\hline & & & & & & & & & & IGGVC & 143,3 \\
\hline
\end{tabular}


Os resultados dos levantamentos locais e dos valores do IGGVC para a Ciclovia Faria Lima, são apresentados no quadro 17, onde:

- FA é a frequência absoluta de ocorrências de cada tipo de defeito;

- $\quad \mathrm{N}$ é o número total de estações;

- FR é frequência relativa de cada tipo de defeito em relação ao número total de estações;

- FP é o fator de ponderação, e;

- IGI é o Índice de Gravidade Individual de cada defeito.

Nota-se que existe uma concentração bem delimitada entre as estações 12 e 20, com ocorrências de todos os defeitos (exceto alçamentos, que não foram localizados em nenhum segmento da Ciclovia Faria Lima) e os maiores valores de desgaste de pintura superficial. Este trecho está entre a Rua Teodoro Sampaio e Rua Benedito Chaves e possui características de intensa circulação ciclística. Nesta área há uma grande estação de compartilhamento de bicicletas (BikeSampa), a Estação de metrô Faria Lima e um bicicletário de funcionamento ininterrupto com cem vagas. A partir destes aspectos, esta área é possivelmente onde há o maior volume de ciclistas, o que pode indicar uma deterioração mais acelerada que em outras áreas da ciclovia.

A respeito dos índices de gravidade individual, as "fissuras isoladas", por mais que possuam um fator de ponderação intermediário $(0,6)$, apresentaram o maior IGI (40): resultado da mais alta frequência absoluta identificada (20 estações). Para este tipo de defeito, não houve uma concentração espacial clara, tendo ocorrido em quase toda a extensão da via (em dois terços das estações). Não considerando o desgaste da cor do pavimento, o defeito de segundo maior IGI são as "tampas de PV ou bocas de lobo", com IGI de 18,7, também com a segunda maior frequência absoluta (7 estações).

Os defeitos menos frequentes foram os buracos e as aberturas de juntas, isto denota uma boa característica para a ciclovia, haja vista que estes defeitos possuem altos fatores de ponderação, ou seja, afetam fortemente a segurança e conforto dos ciclistas pesquisados. 


\subsubsection{Diagnóstico de irregularidade longitudinal (RMSVA)}

Ao todo foram coletados 94.133 valores de aceleração (tendo excluído as coletas para velocidades nulas). O quadro 18 mostra exemplos dos dados brutos coletados.

Quadro 18 - Exemplo parcial de dados brutos de aceleração

\begin{tabular}{|c|c|c|c|c|c|}
\hline Tempo & $\begin{array}{c}\text { Aceleração } \\
\left(\mathbf{m} / \mathbf{s}^{2}\right)\end{array}$ & Latitude & Longitude & Elevação $\mathbf{( m )}$ & $\begin{array}{c}\text { Velocidade } \\
\mathbf{( k m / h )}\end{array}$ \\
\hline 8h51min6s & 14,619 & $-23,55799$ & $-46,71155$ & 725 & 3,4 \\
\hline 8h51min6s & 7,939 & $-23,55799$ & $-46,71155$ & 725 & 3,4 \\
\hline 8h51min6s & 9,357 & $-23,55799$ & $-46,71155$ & 725 & 3,4 \\
\hline 8h51min6s & 12,254 & $-23,55799$ & $-46,71155$ & 725 & 3,4 \\
\hline 8h51min6s & 6,335 & $-23,55799$ & $-46,71155$ & 725 & 3,4 \\
\hline 8h51min7s & 10,669 & $-23,55799$ & $-46,71155$ & 725 & 3,4 \\
\hline 8h51min7s & 8,423 & $-23,55799$ & $-46,71155$ & 725 & 3,4 \\
\hline 8h51min7s & 10,783 & $-23,55799$ & $-46,71155$ & 725 & 3,4 \\
\hline 8h51min7s & 7,982 & $-23,55799$ & $-46,71155$ & 725 & 3,4 \\
\hline 8h51min7s & 8,27 & $-23,55798$ & $-46,71155$ & 725 & 2,9 \\
\hline 8h51min7s & 7,968 & $-23,55798$ & $-46,71155$ & 725 & 2,9 \\
\hline 8h51min7s & 10,731 & $-23,55798$ & $-46,71155$ & 725 & 2,9 \\
\hline 8h51min7s & 8,701 & $-23,55798$ & $-46,71155$ & 725 & 2,9 \\
\hline 8h51min8s & 8,543 & $-23,55798$ & $-46,71155$ & 725 & 2,9 \\
\hline 8h51min8s & 8,557 & $-23,55798$ & $-46,71155$ & 725 & 2,9 \\
\hline 8h51min8s & 8,413 & $-23,55798$ & $-46,71155$ & 725 & 2,9 \\
\hline 8h51min8s & 9,409 & $-23,55798$ & $-46,71155$ & 725 & 2,9 \\
\hline 8h51min8s & 9,275 & $-23,55798$ & $-46,71156$ & 725 & 6,3 \\
\hline 8h51min8s & 8,116 & $-23,55798$ & $-46,71156$ & 725 & 6,3 \\
\hline 8h51min8s & 9,572 & $-23,55798$ & $-46,71156$ & 725 & 6,3 \\
\hline 8h51min8s & 10,544 & $-23,55798$ & $-46,71156$ & 725 & 6,3 \\
\hline 8h51min8s & 7,815 & $-23,55798$ & $-46,71156$ & 725 & 6,3 \\
\hline 8h51min9s & 9,816 & $-23,55798$ & $-46,71156$ & 725 & 6,3 \\
\hline 8h51min9s & 7,226 & $-23,55798$ & $-46,71156$ & 725 & 6,3 \\
\hline 8h51min9s & 8,131 & $-23,55798$ & $-46,71156$ & 725 & 6,3 \\
\hline 8h51min9s & 11,085 & $-23,55798$ & $-46,71156$ & 725 & 6,3 \\
\hline 8h51min9s & 9,673 & $-23,55797$ & $-46,71158$ & 724 & 4 \\
\hline 8h51min9s & 11,708 & $-23,55797$ & $-46,71158$ & 724 & 4 \\
\hline 8h51min9s & 7,321 & $-23,55797$ & $-46,71158$ & 724 & 4 \\
\hline 8h51min9s & 9,878 & $-23,55797$ & $-46,71158$ & 724 & 4 \\
\hline 8h51min9s & 8,495 & $-23,55797$ & $-46,71158$ & 724 & 4 \\
\hline 8h51min10s & 8,217 & $-23,55797$ & $-46,71158$ & 724 & 4 \\
\hline 8h51min10s & 8,964 & $-23,55797$ & $-46,71158$ & 724 & 4 \\
\hline 8h51min10s & 10,817 & $-23,55797$ & $-46,71158$ & 724 & 4 \\
\hline 8h51min10s & 7,25 & $-23,55797$ & $-46,71158$ & 724 & 4 \\
\hline 8h51min10s & 9,562 & $-23,55797$ & $-46,71159$ & 724 & 3,9 \\
\hline & & & & & \\
\hline
\end{tabular}




\begin{tabular}{|c|c|c|c|c|c|}
\hline $8 \mathrm{~h} 51 \min 10 \mathrm{~s}$ & 8,988 & $-23,55797$ & $-46,71159$ & 724 & 3,9 \\
\hline $8 \mathrm{~h} 51 \mathrm{~min} 10 \mathrm{~s}$ & 8,327 & $-23,55797$ & $-46,71159$ & 724 & 3,9 \\
\hline $8 \mathrm{~h} 51 \mathrm{~min} 10 \mathrm{~s}$ & 12,661 & $-23,55797$ & $-46,71159$ & 724 & 3,9 \\
\hline $8 \mathrm{~h} 51 \min 10 \mathrm{~s}$ & 8,38 & $-23,55797$ & $-46,71159$ & 724 & 3,9 \\
\hline $8 \mathrm{~h} 51 \min 11 \mathrm{~s}$ & 8,04 & $-23,55797$ & $-46,71159$ & 724 & 3,9 \\
\hline $8 \mathrm{~h} 51 \min 11 \mathrm{~s}$ & 11,598 & $-23,55797$ & $-46,71159$ & 724 & 3,9 \\
\hline $8 \mathrm{~h} 51 \min 11 \mathrm{~s}$ & 9,519 & $-23,55797$ & $-46,71159$ & 724 & 3,9 \\
\hline $8 \mathrm{~h} 51 \min 11 \mathrm{~s}$ & 9,969 & $-23,55797$ & $-46,71159$ & 724 & 3,9 \\
\hline $8 \mathrm{~h} 51 \min 11 \mathrm{~s}$ & 8,543 & $-23,55797$ & $-46,71161$ & 724 & 3,7 \\
\hline $8 \mathrm{~h} 51 \mathrm{~min} 11 \mathrm{~s}$ & 11,856 & $-23,55797$ & $-46,71161$ & 724 & 3,7 \\
\hline $8 \mathrm{~h} 51 \min 11 \mathrm{~s}$ & 9,194 & $-23,55797$ & $-46,71161$ & 724 & 3,7 \\
\hline $8 \mathrm{~h} 51 \min 11 \mathrm{~s}$ & 11,803 & $-23,55797$ & $-46,71161$ & 724 & 3,7 \\
\hline $8 \mathrm{~h} 51 \min 11 \mathrm{~s}$ & 7,283 & $-23,55797$ & $-46,71161$ & 724 & 3,7 \\
\hline $8 \mathrm{~h} 51 \min 12 \mathrm{~s}$ & 7,547 & $-23,55797$ & $-46,71161$ & 724 & 3,7 \\
\hline $8 \mathrm{~h} 51 \min 12 \mathrm{~s}$ & 9,131 & $-23,55797$ & $-46,71161$ & 724 & 3,7 \\
\hline $8 \mathrm{~h} 51 \min 12 \mathrm{~s}$ & 11,837 & $-23,55797$ & $-46,71161$ & 724 & 3,7 \\
\hline $8 \mathrm{~h} 51 \mathrm{~min} 12 \mathrm{~s}$ & 9,27 & $-23,55797$ & $-46,71161$ & 724 & 3,7 \\
\hline
\end{tabular}

Os valores de aceleração foram obtidos por coordenadas geográficas, de modo que, para cada par de coordenadas, foram fornecidos de 3 a 37 valores de aceleração vertical. O quadro 19 apresenta o total de pares de coordenadas observados neste estudo, agrupados por número de coletas de aceleração vertical. Para cada um desses grupos foram aplicados os cálculos de RMSVA com o objetivo de obter valores de aceleração vertical para cada localização (representadas por pares de coordenadas) da área piloto. A expressiva maioria $(97,61 \%)$ dos pares de coordenadas de toda a amostra foi analisada em grupos de 8 a 10 observações de aceleração vertical.

O quadro 20 apresenta alguns valores estatísticos que descrevem as distribuições de aceleração vertical por via ciclável e a figura 50 mostra a distribuição espacial das médias dos valores de RMSVA. Em concordância com os altos valores dos coeficientes de variação, é importante ressaltar que este resultado de valores médios apenas indica uma visão geral da informação e não pode ser um indicativo direto da irregularidade longitudinal, porque desconsidera outros parâmetros, como as diferentes velocidades das observações, que variaram de forma muito significativa. 
Quadro 19 - Segmentação de acelerações por coletas x pares de coordenadas

\begin{tabular}{|c|c|c|}
\hline $\begin{array}{l}\text { Número de coletas de } \\
\text { aceleração vertical }\end{array}$ & $\begin{array}{l}\text { Total de pares de } \\
\text { coordenadas } \\
\text { observados }\end{array}$ & $\begin{array}{c}\text { Porcentagem de } \\
\text { pares de coordenadas } \\
\text { observados }\end{array}$ \\
\hline 3 & 9 & $0,09 \%$ \\
\hline 4 & 5 & $0,05 \%$ \\
\hline 5 & 3 & $0,03 \%$ \\
\hline 6 & 13 & $0,13 \%$ \\
\hline 7 & 10 & $0,10 \%$ \\
\hline 8 & 1430 & $14,02 \%$ \\
\hline 9 & 6538 & $64,09 \%$ \\
\hline 10 & 1990 & $19,51 \%$ \\
\hline 11 & 5 & $0,05 \%$ \\
\hline 12 & 3 & $0,03 \%$ \\
\hline 13 & 1 & $0,01 \%$ \\
\hline 16 & 3 & $0,03 \%$ \\
\hline 17 & 35 & $0,34 \%$ \\
\hline 18 & 78 & $0,76 \%$ \\
\hline 19 & 60 & $0,59 \%$ \\
\hline 20 & 11 & $0,11 \%$ \\
\hline 21 & 1 & $0,01 \%$ \\
\hline 25 & 1 & $0,01 \%$ \\
\hline 27 & 2 & $0,02 \%$ \\
\hline 28 & 2 & $0,02 \%$ \\
\hline 37 & 2 & $0,02 \%$ \\
\hline
\end{tabular}

Quadro 20 - Estatística descritiva da distribuição de RMSVA

\begin{tabular}{|l|c|c|c|c|c|c|}
\hline \multicolumn{1}{|c|}{ Via ciclável } & $\begin{array}{c}\text { RMSVA } \\
\text { Médio (m/s2) }\end{array}$ & $\begin{array}{c}\text { RMSVA } \\
\text { Mínimo (m/s2) }\end{array}$ & $\begin{array}{c}\text { RMSVA } \\
\text { Máximo } \\
\left(\mathbf{m} / \mathbf{s}^{2}\right)\end{array}$ & $\begin{array}{c}\text { Desvio } \\
\text { padrão } \\
\left(\mathbf{m} / \mathbf{s}^{2}\right)\end{array}$ & $\begin{array}{c}\text { Variância } \\
\left(\mathbf{m} / \mathbf{s}^{2}\right)\end{array}$ & $\begin{array}{c}\text { Coeficiente } \\
\text { de variação } \\
(\%)\end{array}$ \\
\hline $\begin{array}{l}\text { Ciclofaixa Artur de } \\
\text { Azevedo }\end{array}$ & 13,374 & 6,885 & 50,921 & 5,389 & 29,046 & 40,30 \\
\hline Ciclofaixa Consolação & 11,959 & 4,529 & 42,573 & 4,467 & 19,958 & 37,36 \\
\hline Ciclofaixa Honduras & 13,978 & 4,424 & 44,121 & 6,510 & 42,381 & 46,57 \\
\hline Ciclofaixa Itápolis & 14,217 & 4,678 & 47,108 & 5,787 & 33,485 & 40,70 \\
\hline Ciclofaixa João Moura & 12,266 & 3,768 & 45,130 & 5,929 & 35,156 & 48,34 \\
\hline $\begin{array}{l}\text { Ciclofaixa João } \\
\text { Ramalho }\end{array}$ & 14,621 & 5,913 & 61,006 & 7,186 & 51,637 & 49,15 \\
\hline $\begin{array}{l}\text { Ciclofaixa Pacaembu } \\
\text { / Faap / Mackenzie }\end{array}$ & 13,882 & 5,706 & 49,208 & 6,097 & 37,169 & 43,92 \\
\hline Ciclovia Faria Lima & 11,634 & 4,457 & 41,393 & 4,251 & 18,068 & 36,54 \\
\hline Ciclovia Pacaembu & 11,355 & 6,028 & 42,765 & 3,494 & 12,211 & 30,77 \\
\hline Ciclovia Paulista & 11,518 & 5,829 & 42,076 & 3,850 & 14,821 & 33,42 \\
\hline Ciclovia Sumaré & 13,033 & 4,216 & 43,735 & 4,668 & 21,789 & 35,82 \\
\hline \multicolumn{1}{|c|}{ Total Geral } & 12,746 & 3,768 & 61,006 & 5,378 & 28,925 & 42,20 \\
\hline
\end{tabular}


Figura 50 - Mapa da média de RMSVA por via ciclável

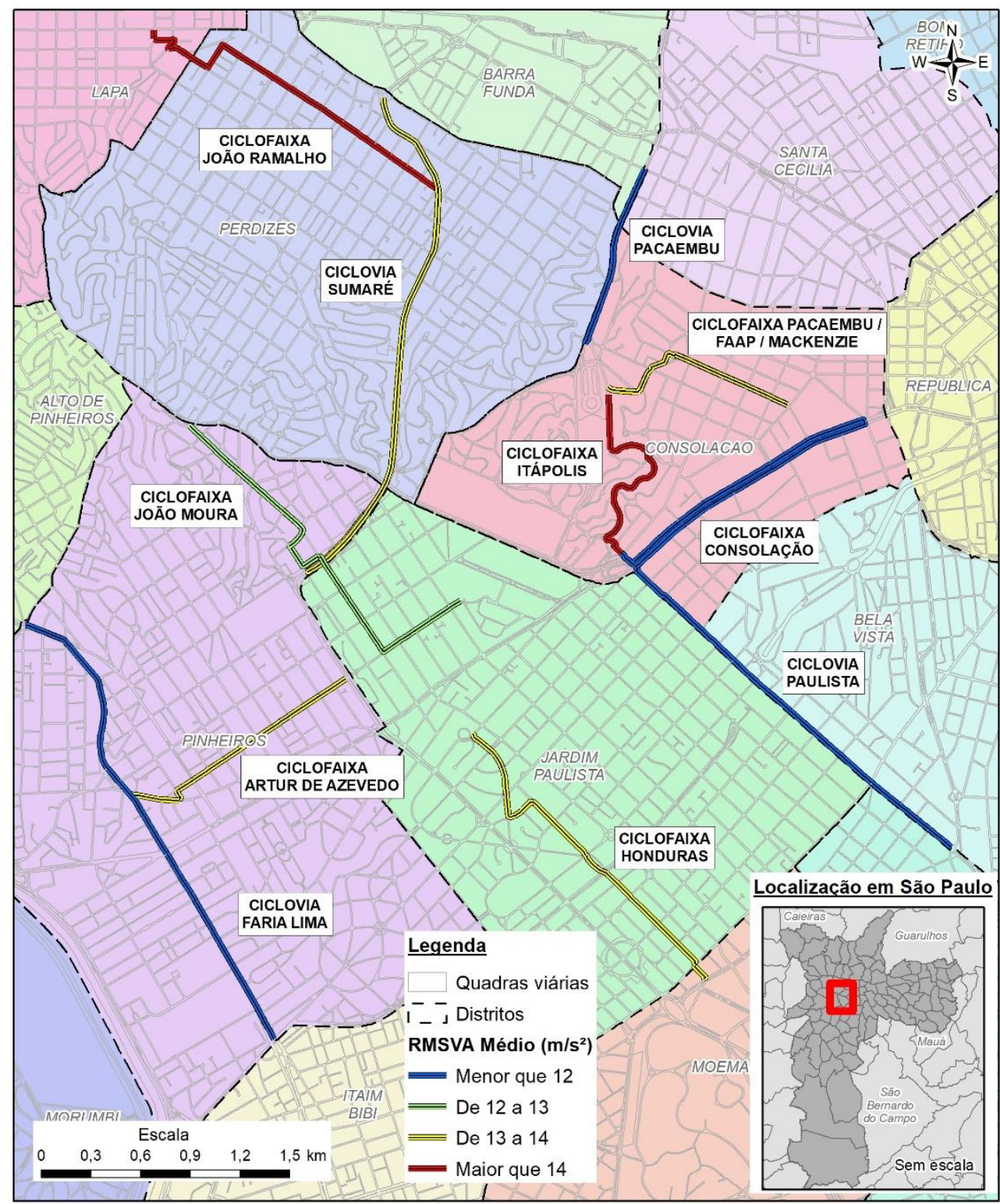

Fonte: produzido e compilado pelo autor ${ }^{14}$

Por conta das limitações explicitadas anteriormente, os valores de aceleração foram captados com velocidades inconstantes, o que dificulta a comparação entre os segmentos e com a bibliografia de referência. Desta forma, foram propostas uma segmentação e uma análise dos dados com base em intervalos de velocidades que são apresentados a seguir.

${ }^{14}$ Compilação dos vetores de vias cicláveis, quadras viárias, distritos e municípios disponibilizados pela Prefeitura de São Paulo em março de 2018 por meio do sítio <http://geosampa.prefeitura.sp.gov.br/PaginasPublicas/_SBC.aspx>. 
Para que fosse possível comparar os resultados de RMSVA, foram localizados segmentos de vias em que as características e velocidades de observação fossem semelhantes. Assim, selecionaram-se segmentos de mesma tipologia, de média de velocidade de coleta semelhantes (no caso, de $15 \mathrm{~km} / \mathrm{h}$ a 20 $\mathrm{km} / \mathrm{h}$ ) e de coeficiente de variação da velocidade menor que $20 \%$. O quadro 21 indica os segmentos de via definidos e as informações supracitadas.

Quadro 21 - Velocidades de coleta de RMSVA dos segmentos analisados

\begin{tabular}{|l|c|c|c|c|c|}
\hline & & \multirow{2}{*}{ Via Ciclável } & Segmento & Extensão & \multicolumn{3}{c|}{ Velocidade } \\
\cline { 5 - 6 } & & & $\begin{array}{c}\text { Desvio padrão } \\
(\mathbf{k m} / \mathbf{h})\end{array}$ & $\begin{array}{c}\text { Média } \\
\mathbf{( k m / h )}\end{array}$ & $\begin{array}{c}\text { Coeficiente de } \\
\text { variação (\%) }\end{array}$ \\
\hline Ciclofaixa Artur de Azevedo & CFAA5 & 117,04 & 3,82 & 19,99 & 19,12 \\
\hline Ciclofaixa Artur de Azevedo & CFAA6 & 107,96 & 3,06 & 18,84 & 16,23 \\
\hline Ciclofaixa Artur de Azevedo & CFAA8 & 117,52 & 2,14 & 16,63 & 12,85 \\
\hline Ciclofaixa Artur de Azevedo & CFAA14 & 201,04 & 3,85 & 19,97 & 19,27 \\
\hline Ciclofaixa Consolação & CFCO13 & 193,56 & 2,29 & 16,69 & 13,71 \\
\hline Ciclofaixa Honduras & CFHO5 & 90,94 & 2,25 & 17,10 & 13,14 \\
\hline Ciclofaixa Honduras & CFHO10 & 87,73 & 1,98 & 18,10 & 10,92 \\
\hline Ciclofaixa Honduras & CFHO11 & 112,21 & 2,84 & 17,18 & 16,54 \\
\hline Ciclofaixa Itápolis & CFIT3 & 421,74 & 3,09 & 15,52 & 19,90 \\
\hline Ciclofaixa João Ramalho & CFJR9 & 80,76 & 2,56 & 16,32 & 15,68 \\
\hline Ciclofaixa João Ramalho & CFJR10 & 119,68 & 2,55 & 16,23 & 15,72 \\
\hline Ciclofaixa João Ramalho & CFJR19 & 109,55 & 1,81 & 17,40 & 10,38 \\
\hline Ciclovia Faria Lima & CVFL3 & 205,93 & 2,54 & 17,06 & 14,92 \\
\hline Ciclovia Faria Lima & CVFL4 & 93,52 & 2,22 & 17,11 & 12,96 \\
\hline Ciclovia Faria Lima & CVFL5 & 134,66 & 1,94 & 17,57 & 11,04 \\
\hline Ciclovia Faria Lima & CVFL7 & 124,03 & 1,49 & 19,36 & 7,70 \\
\hline Ciclovia Faria Lima & CVFL8 & 108,23 & 2,61 & 17,89 & 14,60 \\
\hline Ciclovia Faria Lima & CVFL13 & 117,41 & 3,41 & 17,34 & 19,66 \\
\hline Ciclovia Pacaembu & CVPA1 & 369,01 & 1,01 & 18,62 & 5,43 \\
\hline Ciclovia Pacaembu & CVPA3 & 400,93 & 3,65 & 18,25 & 20,00 \\
\hline Ciclovia Paulista & CVPT3 & 116,43 & 1,96 & 19,90 & 9,84 \\
\hline Ciclovia Paulista & CVPT9 & 102,09 & 2,51 & 19,10 & 13,12 \\
\hline Ciclovia Sumarén & CVSU2 & 99,15 & 2,69 & 19,64 & 13,68 \\
\hline Ciclovia Sumarén & CVSU14 & 103,67 & 3,06 & 18,05 & 16,97 \\
\hline
\end{tabular}

O resultado das médias dos valores de RMSVA dos segmentos selecionados (quadro 22) variaram entre 10,94 m/s (CVFL4) e 24,73 m/s² (CFHO5), sendo seu valor médio de $14,02 \mathrm{~m} / \mathrm{s}^{2}$. O que se destaca nestes resultados é a concentração de valores mais baixos para as ciclovias e mais altos para as ciclofaixas (como indica a 
figura 51). Isto pode ser explicado pela hipótese de que os valores reais de irregularidade longitudinal nos pavimentos de concreto (ciclovias) da área piloto sejam menores que os valores dos pavimentos asfálticos (ciclofaixas).

Quadro 22 - Resultados de RMSVA por segmento

\begin{tabular}{|l|c|c|}
\hline \multicolumn{1}{|c|}{ Via Ciclável } & Segmento & Média de RMSVA (m/s') \\
\hline Ciclofaixa Artur de Azevedo & CFAA5 & 14,69 \\
\hline Ciclofaixa Artur de Azevedo & CFAA6 & 18,56 \\
\hline Ciclofaixa Artur de Azevedo & CFAA8 & 12,46 \\
\hline Ciclofaixa Artur de Azevedo & CFAA14 & 12,75 \\
\hline Ciclofaixa Consolação & CFCO13 & 13,71 \\
\hline Ciclofaixa Honduras & CFHO5 & 24,73 \\
\hline Ciclofaixa Honduras & CFHO10 & 11,60 \\
\hline Ciclofaixa Honduras & CFHO11 & 14,23 \\
\hline Ciclofaixa Itápolis & CFIT3 & 14,61 \\
\hline Ciclofaixa João Ramalho & CFJR9 & 17,62 \\
\hline Ciclofaixa João Ramalho & CFJR10 & 20,31 \\
\hline Ciclofaixa João Ramalho & CFJR19 & 12,64 \\
\hline Ciclovia Faria Lima & CVFL3 & 12,49 \\
\hline Ciclovia Faria Lima & CVFL4 & 10,94 \\
\hline Ciclovia Faria Lima & CVFL5 & 11,50 \\
\hline Ciclovia Faria Lima & CVFL7 & 14,74 \\
\hline Ciclovia Faria Lima & CVFL8 & 13,76 \\
\hline Ciclovia Faria Lima & CVFL13 & 11,35 \\
\hline Ciclovia Pacaembu & CVPA1 & 11,20 \\
\hline Ciclovia Pacaembu & CVPA3 & 11,15 \\
\hline Ciclovia Paulista & CVPT3 & 13,21 \\
\hline Ciclovia Paulista & CVPT9 & 11,54 \\
\hline Ciclovia Sumaré & CVSU2 & 15,05 \\
\hline Ciclovia Sumaré & CVSU14 & 11,60 \\
\hline & Geral & $\mathbf{1 4 , 0 2}$ \\
\hline
\end{tabular}


Figura 51 - Gráfico de média de RMSVA por segmento

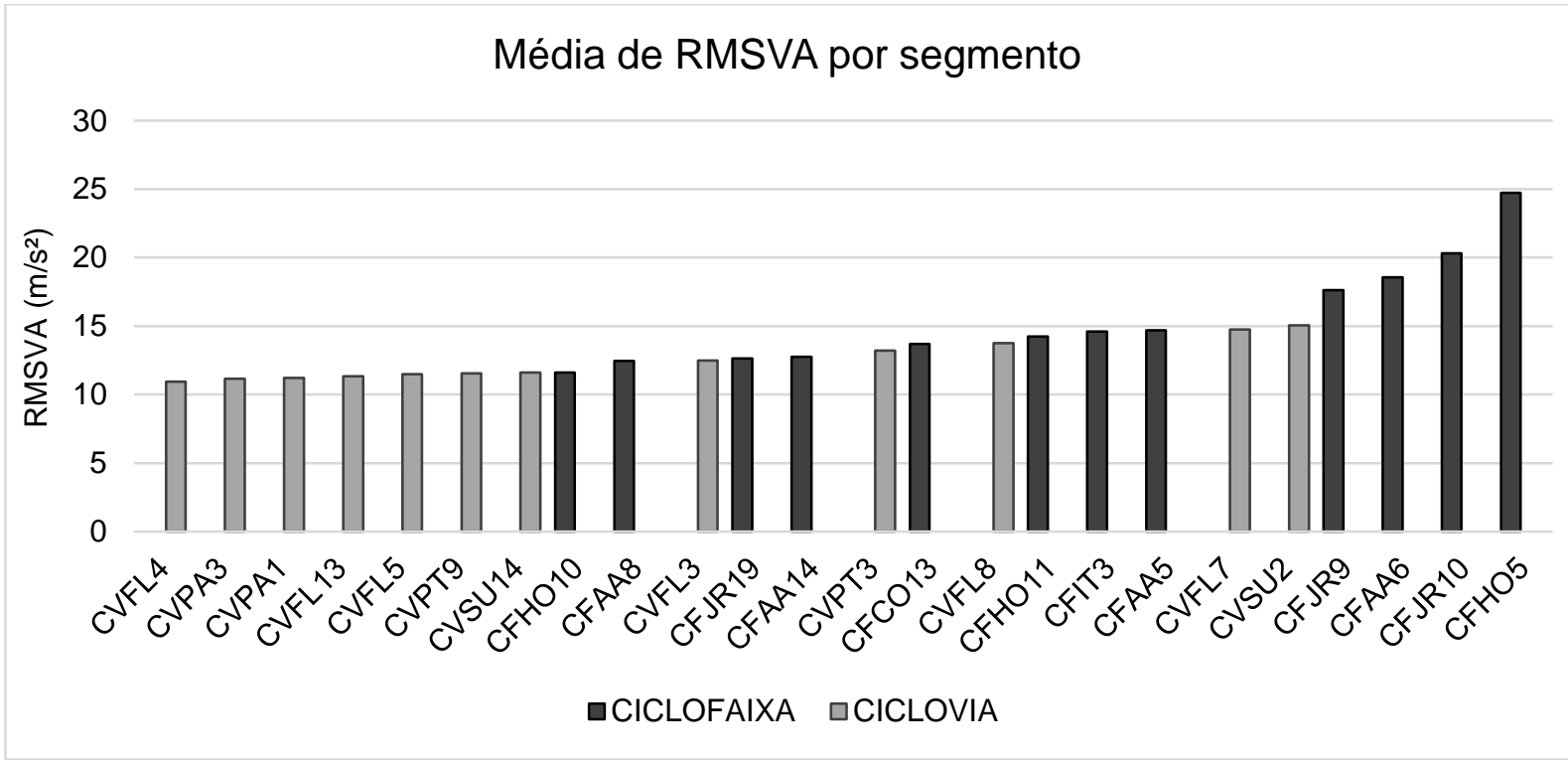

Também pode ser entendido que as ciclofaixas, como podem sofrer interferências dos veículos automotores, passam por processos mais acelerados de deterioração em relação às ciclovias. Para tanto, utilizou-se os dados do inventário geral de defeitos e patologias (seção 6.1.2) para uma melhor compreensão das acelerações verticais coletadas.

Por mais que não seja estatisticamente seguro relacionar diretamente a ocorrência de defeitos com os resultados de RMSVA (dada a pequena amostra levantada neste trabalho), é possível compará-los com contagens de defeitos por extensão, como mostra a figura 52. Existe uma correlação positiva entre estas métricas $\left(r^{2}=0,3679\right)$ que possibilita o entendimento de que vias com mais defeitos, tendem a apresentar valores de RMSVA também maiores.

Seguramente, existem ressalvas nesta relação, dado que entre os defeitos há o desgaste da cor do pavimento (que não afeta a irregularidade longitudinal) e os buracos que, se não ocuparem toda a área útil da via, podem ser evitados pelo ciclista, anulando a captura dos sinais de aceleração vertical referente a este defeito. Contudo, para coletas de dados com repetitividades mais altas e para objetivos de avaliação de qualidade de pavimentos em nível de projeto, estes resultados podem ser indicadores de deterioração e contribuir para a tomada de decisão em relação a ações de auditoria e manutenção. 
Figura 52 - Correlação entre contagens de defeitos/km e RMSVA médio

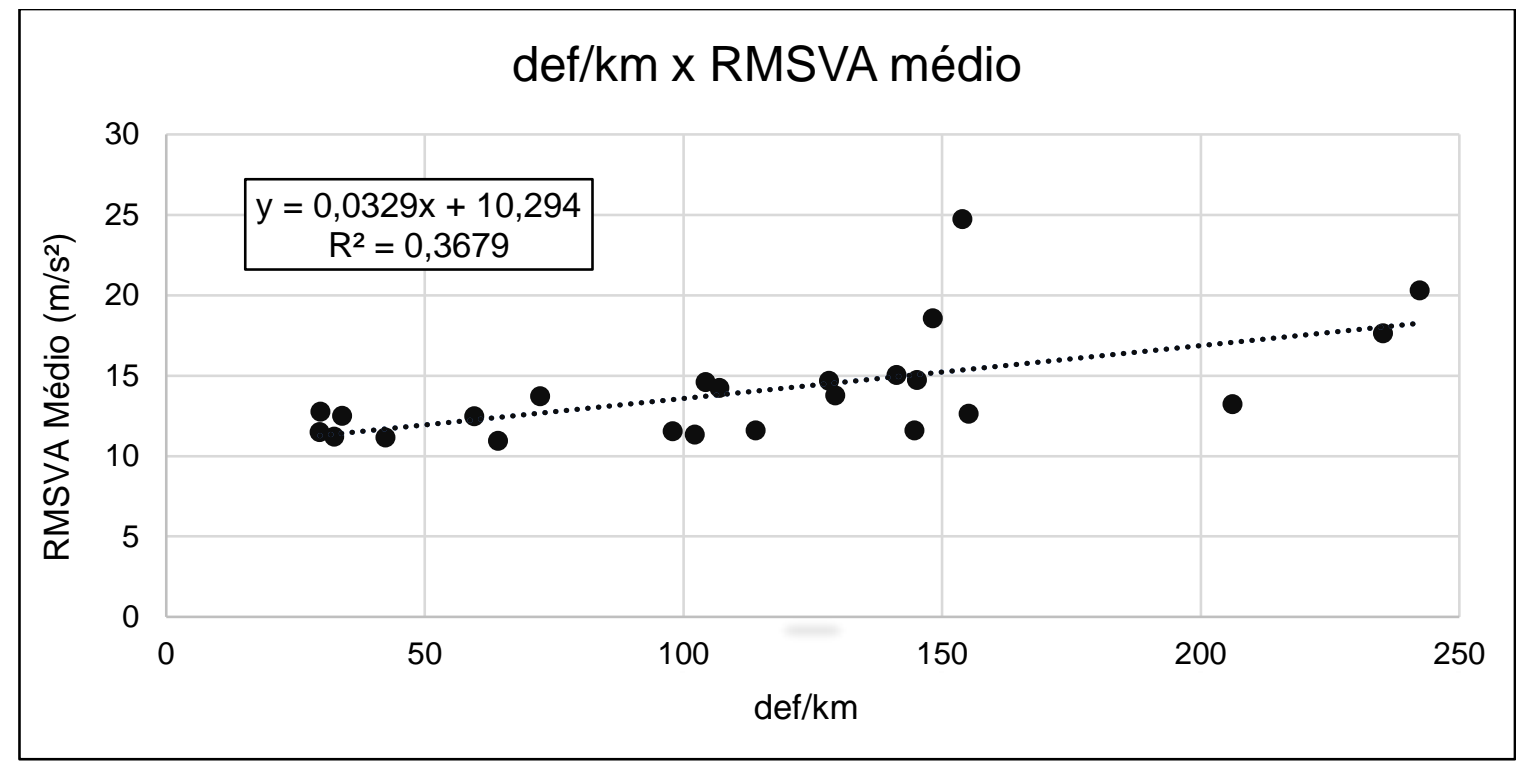

\subsection{Avaliação da Adequação Geométrica}

A avaliação da adequação geométrica foi composta por três indicadores. primeiro relaciona as larguras das vias cicláveis e os valores mínimos que garantem a segurança do ciclista. O segundo é resultado das observações de velocidade máxima permitida de veículos automotores nas ruas e avenidas lindeiras às vias cicláveis. O terceiro avaliou as declividades das vias cicláveis no sentido de que áreas íngremes são menos atrativas (dada à dificuldade em superá-las) e seguras (devido às altas velocidades do ciclista na descida).

As larguras das ciclovias foram coletadas integralmente, enquanto as larguras das ciclofaixas foram separadas da largura da sarjeta. Por mais que os ciclistas possam vir a utilizar a sarjeta, esta foi desconsiderada nesta análise, ou seja, apenas a largura efetiva foi contabilizada. Os valores médios coletados de larguras efetivas para cada tipologia e direcionalidade estão no quadro 23 , e apontam uma inadequação das larguras das ciclofaixas e uma parcial adequação das ciclovias.

Quadro 23 - Valores médios de larguras identificados

\begin{tabular}{|c|c|c|c|c|}
\hline \multirow{2}{*}{ Tipologia } & \multicolumn{2}{|c|}{ Bidirecional } & \multicolumn{2}{c|}{ Unidirecional } \\
\cline { 2 - 5 } & Largura & Adequação & Largura & Adequação \\
\hline Ciclofaixa & $1,48 \mathrm{~m}$ & Inadequado & $0,83 \mathrm{~m}$ & Inadequado \\
\hline Ciclovia & $2,43 \mathrm{~m}$ & Parcialmente adequado & $1,45 \mathrm{~m}$ & Parcialmente adequado \\
\hline
\end{tabular}


O quadro 24 mostra que mais de $70 \%$ da área piloto não se adequa aos critérios de largura indicados e a figura 53 espacializa estes resultados por segmentos de via.

Quadro 24 - Adequação de larguras

\begin{tabular}{|c|c|c|c|}
\hline $\begin{array}{c}\text { Adequação de largura de via } \\
\text { ciclável }\end{array}$ & $\begin{array}{c}\text { Total de } \\
\text { segmentos }\end{array}$ & $\begin{array}{c}\text { Extensão } \\
\text { (m) }\end{array}$ & $\begin{array}{c}\text { Percentual da } \\
\text { área piloto }\end{array}$ \\
\hline Inadequado & 108 & 18710,01 & $70,46 \%$ \\
\hline Parcialmente inadequado & 21 & 3206,66 & $12,08 \%$ \\
\hline Parcialmente adequado & 7 & 1479,19 & $5,57 \%$ \\
\hline Plenamente adequado & 20 & 3156,65 & $11,89 \%$ \\
\hline
\end{tabular}

Figura 53 - Mapa do resultado do indicador de largura

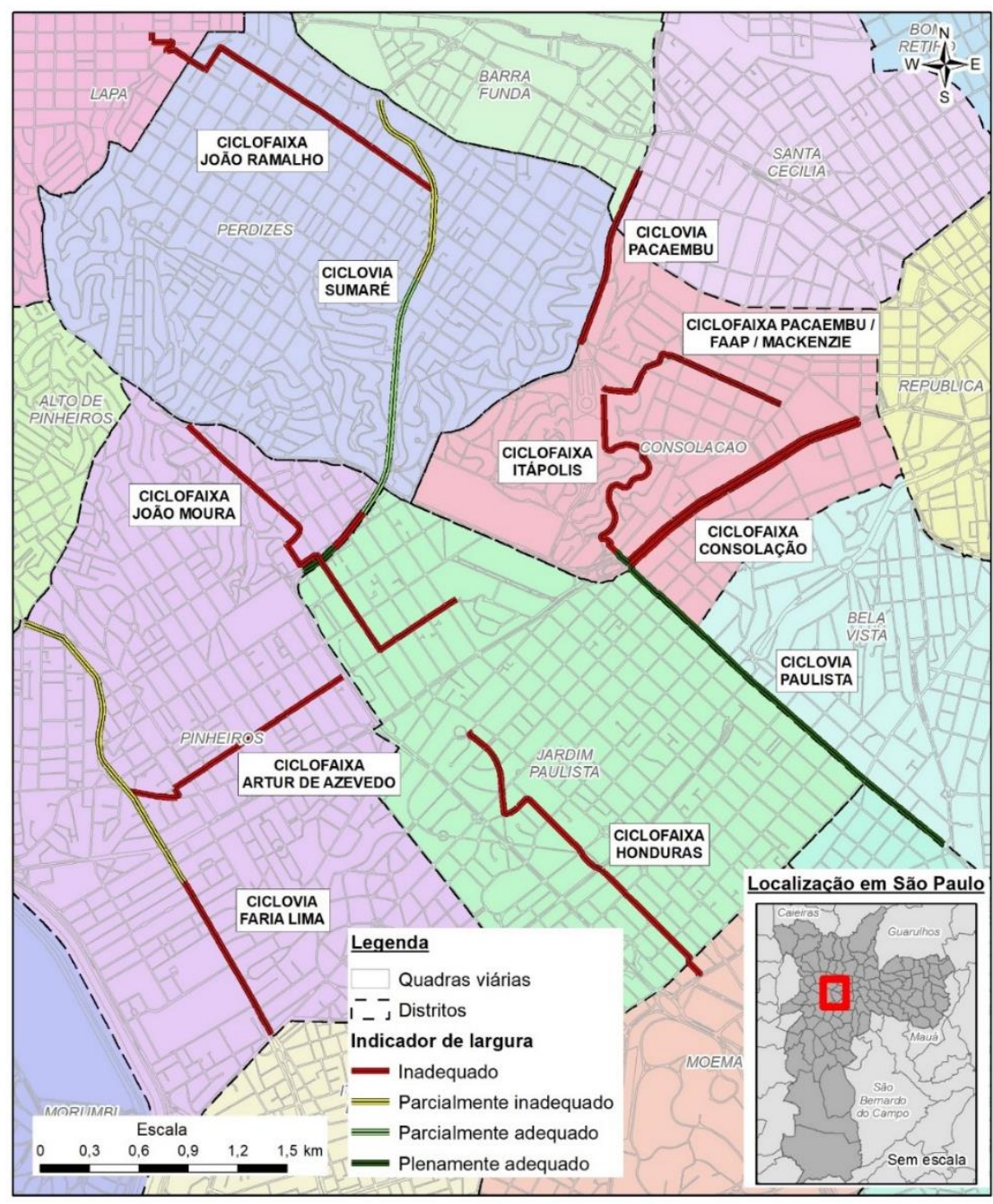

Fonte: material produzido e compilado pelo autor ${ }^{15}$

${ }^{15}$ Compilação dos vetores de vias cicláveis, quadras viárias, distritos e municípios disponibilizados pela Prefeitura de São Paulo em março de 2018 por meio do sítio <http://geosampa.prefeitura.sp.gov.br/PaginasPublicas/_SBC.aspx>. 
O indicador de velocidade pretende avaliar a segurança do ciclista em relação aos veículos automotores da via adjacente, de modo que, velocidades muito altas sem uma segregação mínima de segurança (que, em geral, as ciclofaixas não apresentam) vulnerabilizam o ciclista. Desta forma, a presente avaliação propôs o critério de adequação de até $50 \mathrm{~km} / \mathrm{h}$ para ciclovias e $40 \mathrm{~km} / \mathrm{h}$ para ciclofaixas.

Todas os segmentos de via da área piloto foram checados e apenas a Rua da Consolação apresentava inadequação quanto a estes critérios. Sendo ela composta por vias de carros de velocidade máxima de $50 \mathrm{~km} / \mathrm{h}$ e vias cicláveis de tipologia ciclofaixa, entende-se que o risco de acidentes é significativo. Todas as outras vias foram consideradas adequadas quanto a este critério.

O resultado do indicador de declividade está representado na figura 54, bem como no quadro 25 , que mostra que a maioria $(72,50 \%)$ das vias cicláveis é adequada ao trânsito cicloviário, no tocante às suas inclinações. Apenas cinco segmentos foram classificados como inadequados, estando quatro localizados na Ciclofaixa da João Moura, e um na Ciclofaixa João Ramalho.

Quadro 25 -Adequação do indicador de declividade

\begin{tabular}{|l|c|c|c|}
\hline $\begin{array}{c}\text { Adequação de declividade de } \\
\text { via ciclável }\end{array}$ & $\begin{array}{c}\text { Total de } \\
\text { segmentos }\end{array}$ & $\begin{array}{c}\text { Extensão } \\
(\mathbf{m})\end{array}$ & $\begin{array}{c}\text { Percentual da } \\
\text { área piloto }\end{array}$ \\
\hline Inadequado & 5 & 459,97 & $1,73 \%$ \\
\hline Parcialmente inadequado & 12 & 1945,35 & $7,33 \%$ \\
\hline Parcialmente adequado & 25 & 4895,84 & $18,44 \%$ \\
\hline Plenamente adequado & 114 & 19251,37 & $72,50 \%$ \\
\hline
\end{tabular}

Os valores médios, máximo e mínimos de declividades de cada via ciclável estão descritos no quadro 26, que também indica que o valor médio de toda área piloto $(2,22 \%)$ a classifica como plenamente adequada, segundo os critérios previamente estabelecidos. 
Figura 54 - Mapa do resultado do indicador de declividade

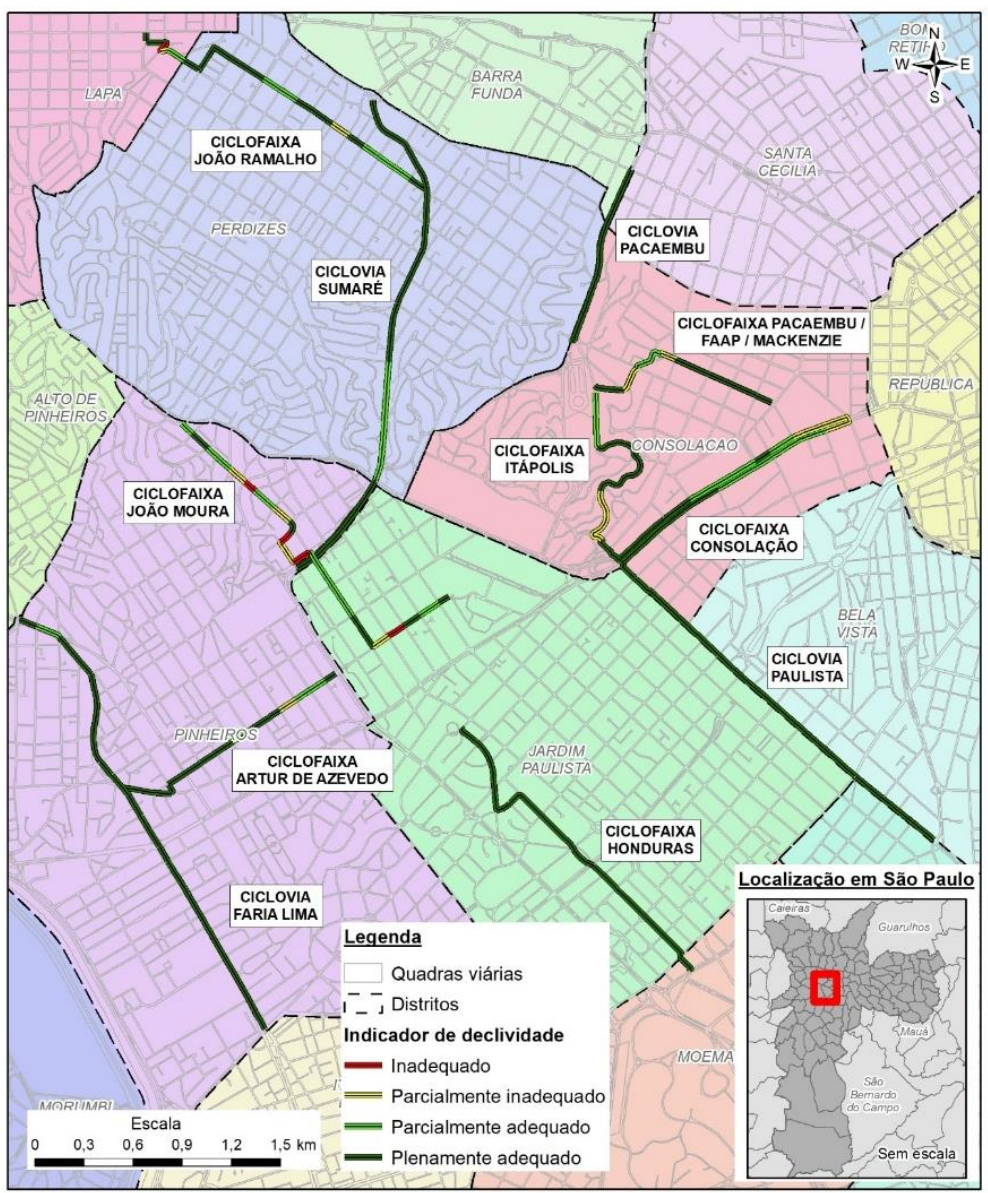

Fonte: material produzido e compilado pelo autor ${ }^{16}$

Quadro 26 - Valores médios, mínimos e máximos de declividade

\begin{tabular}{|c|c|c|c|}
\hline \multirow{2}{*}{ Via ciclável } & \multicolumn{3}{|c|}{ Declividade (\%) } \\
\hline & Média & Mínima & Máxima \\
\hline Ciclofaixa Artur de Azevedo & 2,04 & 0,09 & 7,06 \\
\hline Ciclofaixa Consolação & 3,13 & 0,25 & 5,88 \\
\hline Ciclofaixa Honduras & 0,71 & 0,02 & 1,91 \\
\hline Ciclofaixa Itápolis & 2,75 & 0,19 & 5,42 \\
\hline Ciclofaixa João Moura & 4,98 & 0,71 & 10,26 \\
\hline Ciclofaixa João Ramalho & 3,33 & 0,04 & 8,25 \\
\hline Ciclofaixa Pacaembu / Faap / Mackenzie & 2,54 & 0,15 & 5,66 \\
\hline Ciclovia Faria Lima & 0,99 & 0,03 & 3,62 \\
\hline Ciclovia Pacaembu & 0,94 & 0,81 & 1,13 \\
\hline Ciclovia Paulista & 0,48 & 0,07 & 1,31 \\
\hline Ciclovia Sumaré & 1,87 & 0,16 & 4,65 \\
\hline Total & 2,22 & 0,02 & 10,26 \\
\hline
\end{tabular}

${ }^{16}$ Compilação dos vetores de vias cicláveis, quadras viárias, distritos e municípios disponibilizados pela Prefeitura de São Paulo em março de 2018 por meio do sítio <http://geosampa.prefeitura.sp.gov.br/PaginasPublicas/_SBC.aspx>. 


\subsubsection{Diagnóstico de adequação geométrica (IAGVC)}

Para que fosse possível uma avaliação integrada dos três indicadores de geometria apresentados, foram definidas notas para cada uma das classes, variando de 0 a 1 da seguinte maneira (quadro 27):

Quadro 27 - Notas para classes de geometria

\begin{tabular}{|c|c|}
\hline Classe de geometria & Nota \\
\hline Plenamente adequado & 1 \\
\hline Parcialmente adequado & 0,75 \\
\hline Parcialmente inadequado & 0,5 \\
\hline Inadequado & 0,25 \\
\hline
\end{tabular}

Assim, foi calculada a média dos três indicadores para cada segmento de via ciclável, gerando o Indicador de Adequação Geométrica Adaptado a Vias Cicláveis (IAGVC), que está representado espacialmente na figura 55.

Não foi encontrado nenhum segmento plenamente inadequado, contudo há uma alta concentração de segmentos "parcialmente inadequados" na Ciclofaixa Consolação, que possui um IAGVC médio de 0,53 e apresenta o menor valor de toda a amostra $(0,42)$. O quadro 28 apresenta os valores médios, mínimos e máximos de IAGVC para cada uma das vias cicláveis.

Quadro 28 - Valores médios, mínimos e máximos de IAGVC

\begin{tabular}{|c|c|c|c|}
\hline \multirow{2}{*}{ Via ciclável } & \multicolumn{3}{|c|}{ IAGVC } \\
\hline & Médio & Mínimo & Máximo \\
\hline Ciclofaixa Artur de Azevedo & 0,72 & 0,58 & 0,75 \\
\hline Ciclofaixa Consolação & 0,53 & 0,42 & 0,58 \\
\hline Ciclofaixa Honduras & 0,75 & 0,75 & 0,75 \\
\hline Ciclofaixa Itápolis & 0,70 & 0,58 & 0,75 \\
\hline Ciclofaixa João Moura & 0,64 & 0,50 & 0,75 \\
\hline Ciclofaixa João Ramalho & 0,70 & 0,50 & 0,75 \\
\hline $\begin{array}{l}\text { Ciclofaixa Pacaembu / Faap / } \\
\text { Mackenzie }\end{array}$ & 0,70 & 0,58 & 0,75 \\
\hline Ciclovia Faria Lima & 0,81 & 0,75 & 0,83 \\
\hline Ciclovia Pacaembu & 0,75 & 0,75 & 0,75 \\
\hline Ciclovia Paulista & 1,00 & 1,00 & 1,00 \\
\hline Ciclovia Sumaré & 0,86 & 0,75 & 1,00 \\
\hline Total & 0,75 & 0,42 & 1,00 \\
\hline
\end{tabular}


Figura 55 - Mapa dos resultados de IAGVC

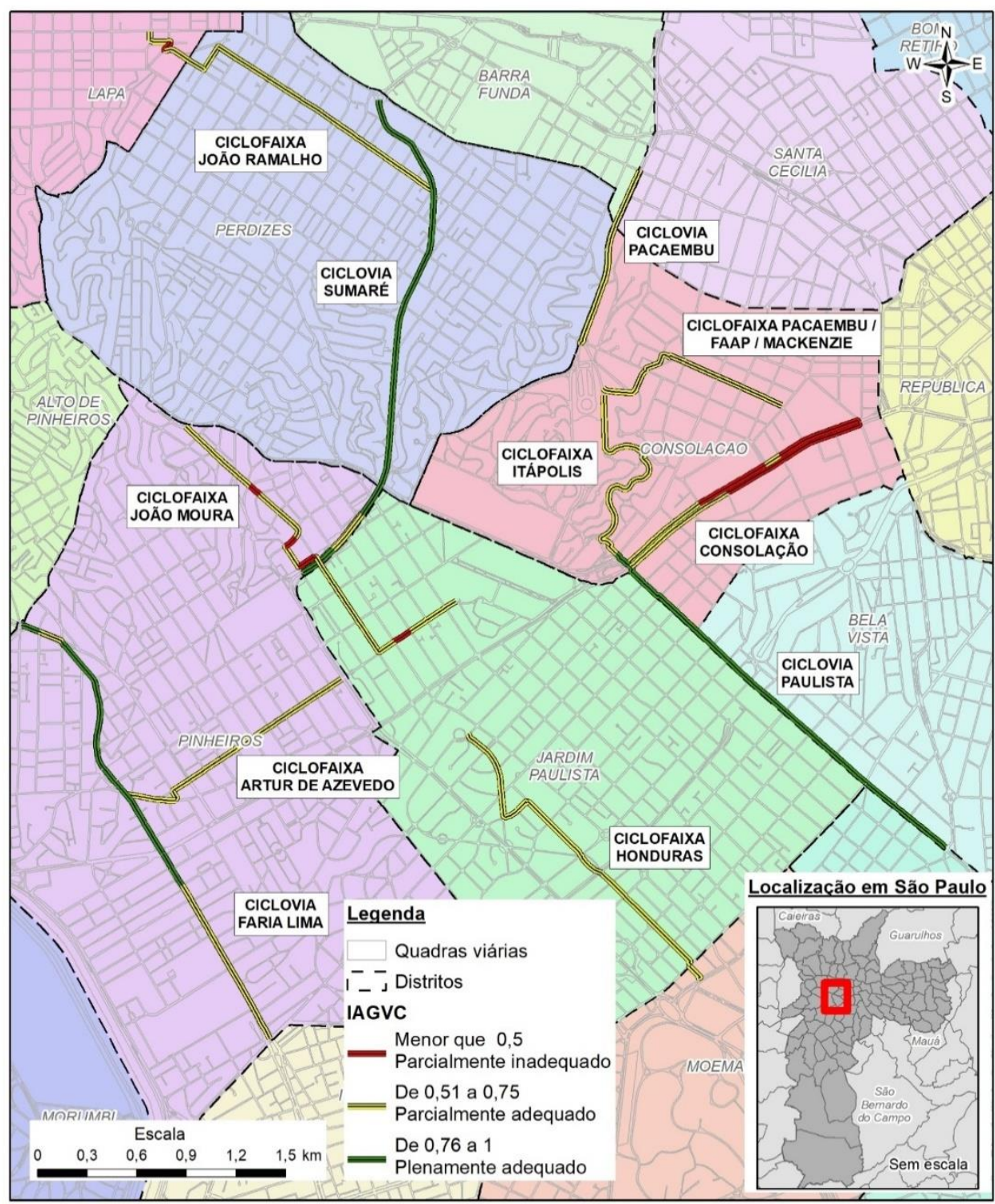

Fonte: material produzido e compilado pelo autor ${ }^{17}$

Como mostra o quadro 29, a rede piloto é, em grande parte classificada como parcialmente adequada (62,11\%) e como plenamente adequada (28,95\%) em relação ao IAGVC. Apenas 8,94\% das vias são parcialmente inadequadas, o que indica que a área piloto possui boa adequação geométrica.

${ }^{17}$ Compilação dos vetores de vias cicláveis, quadras viárias, distritos e municípios disponibilizados pela Prefeitura de São Paulo em março de 2018 por meio do sítio <http://geosampa.prefeitura.sp.gov.br/PaginasPublicas/_SBC.aspx>. 
Quadro 29 - Adequação do IAGVC

\begin{tabular}{|c|c|c|c|}
\hline IAGVC & $\begin{array}{c}\text { Total de } \\
\text { segmentos }\end{array}$ & Extensão (m) & $\begin{array}{c}\text { Percentual da } \\
\text { área piloto }\end{array}$ \\
\hline Parcialmente inadequado & 12 & 2372,59 & $8,94 \%$ \\
\hline Parcialmente adequado & 97 & 16492,94 & $62,11 \%$ \\
\hline Plenamente adequado & 47 & 7686,99 & $28,95 \%$ \\
\hline
\end{tabular}

É importante ressaltar que, como os três indicadores possuem a mesma importância matemática na análise proposta, este modelo de avaliação pode ser revisado, a fim de ter mais robustez. Os altos valores dos indicadores de declividade e velocidade podem ter minimizado a importância do indicador de largura que, de fato, é muito significante para a avaliação de segurança cicloviária. Desta forma, sugere-se outras abordagens para estes indicadores em trabalhos futuros. 


\section{CONCLUSÕES E RECOMENDAÇÕES}

O transporte cicloviário, que tem um alto potencial de influenciar positivamente diversos aspectos de uma comunidade, não acontece nas cidades apenas pela circulação de bicicletas e ciclistas, mas também pelos pavimentos e os elementos de segurança que os dão suporte. Pensar em garantir uma infraestrutura de qualidade, segura, com manutenção adequada, é também garantir estes benefícios para a sociedade.

Com base nas perspectivas que os sistemas de gerência de pavimentos fornecem, foram traçados objetivos que considerassem a avaliação dos aspectos geométricos e de qualidade de pavimentos na cidade de São Paulo, que possui a mais extensa infraestrutura cicloviária permanente da América Latina.

A partir da experiência oriunda das vistorias preliminares da área piloto, foi possível identificar os principais desafios para os ciclistas, no tocante à qualidade dos pavimentos e dos aspectos geométricas das vias.

Um resultado que mais se destaca deste trabalho foi o catálogo de defeitos e patologias de vias cicláveis. Certamente ele pode vir a ser ampliado, mas é um avanço ao apresentar uma estrutura que subsidiará trabalhos de temas relacionados ao planejamento urbano ou o desenvolvimento de modelos de deterioração de pavimentos cicloviários.

Outra contribuição importante, foram os resultados do questionário de percepção comparada de defeitos e patologias de vias cicláveis. Eles ampliaram a abrangência deste trabalho, ao incluir a opinião de ciclistas que efetivamente transitam em São Paulo e sentem diariamente as dificuldades e vulnerabilidades a que estão expostos. Para além dos aspectos formais, esta pesquisa também pretendeu contribuir para que os atuais e futuros ciclistas fossem beneficiados e encorajados a pensar criticamente sobre sua cidade e a defender seu direito a circulação confortável e segura.

Em complementação a estes resultados, foram obtidos valores de aceleração vertical que indicaram caminhos possíveis para avaliação da situação de irregularidade longitudinal das vias cicláveis por meio do índice RMSVA. Os testes desenvolvidos neste trabalho apontaram lacunas importantes neste tipo de avaliação com acelerômetros de smartphones embarcados em bicicletas, como: a necessidade de se adotar velocidades constantes para possibilitar a comparação 
entre os resultados ou a necessidade de se fazer observações com repetitividades mais altas para melhorar a robustez estatística.

Acerca dos aspectos geométricos das vias cicláveis da área piloto, foram abordados três parâmetros principais: as declividades, as larguras e as velocidades. Sobre o último, trabalhos futuros podem incluir as velocidades operacionais das vias dos veículos automotores, e não apenas as indicadas como máximas, para que seja possível avaliar de forma mais efetiva os riscos a que os ciclistas estão expostos. Também se sugere a consideração das velocidades dos próprios ciclistas, dado que estes também podem aumentar sua vulnerabilidade por comportamentos não seguros.

Sendo assim, conclui-se que os objetivos deste trabalho foram alcançados ao analisar, testar e desenvolver métodos de avaliação de qualidade de pavimentos e de adequação geométrica de vias cicláveis. Contudo, sugere-se que esses indicadores sejam reavaliados e aprimorados para serem considerados na construção de políticas públicas relacionadas a redes cicloviárias.

Ademais, recomenda-se que este trabalho seja incluído em futuras discussões sobre o estabelecimento de diretrizes e normas oficiais que determinem níveis de qualidade para infraestruturas de redes cicloviárias. Também, para escopos mais amplos, espera-se que os resultados deste trabalho sejam incorporados ao desenvolvimento de sistemas de gerência de pavimentos cicloviários que considerem modelos de desempenho e avaliações econômicas para o município de São Paulo e outras cidades do Brasil. 


\section{REFERÊNCIAS BIBLIOGRÁFICAS}

AASHTO. Guide for the Development of Bicycle Facilities. 4 ed. Washington DC: AASHTO, 2012.

AMIGO, I. UM carro a menos? Trocando o carro pela bicicleta. In: Estudos de mobilidade por bicicleta, São Paulo: Cebrap, 2018.

ARGUELLES, G. M.; FUENTES, L. G.; ALDANA, L. M. T. Revisión del sistema de gestión de pavimentos de la red ciclorrutas de Bogotá. In: Revista Ingeniería de Construcción, Santiago: Pontificia Universidad Católica de Chile, v. 26, n. 2, p. 150170, 2011.

BALBO, J. T. Pavimentos asfálticos - Patologias e Manutenção. São Paulo: Plêiade, 1997.

Pavimentos de concreto. São Paulo: Oficina de Textos, 2009.

BALBO, J. T. Pavimentação Asfáltica - Materiais, projeto e restauração. São Paulo: Oficina de Textos, 2016.

BARBUDO, A.; JIMÉNEZ, J. R.; LEDESMA, E. F.; SIERRA, M. J. Regularidad superficial y adherencia em vías ciclistas - recomendaciones de diseño disponibles. In: Informes de la Construcción, Madri, v. 670, n. 540, 2015.

BíL, M.; ANDRÁŠIK, R.; KUBEČEK, J. How comfortable are your cycling tracks? A new method for objective bicycle vibration measurement. In: Transportation Research Part C: Emerging Technologies, Amsterdã, v. 56, p. 415-425, 2015.

BARELLA, R. M. Contribuição para a avaliação da irregularidade longitudinal de pavimentos com perfilômetros inerciais. Tese de Doutorado. Escola Politécnica da Universidade de São Paulo, 2008.

BERNUCCI, L. B.; MOTTA, L. M. G.; CERATTI, J. A. P.; SOARES, J. B. Pavimentação asfáltica: formação básica para engenheiros. Rio de Janeiro: PETROBRAS: ABEDA, 2006.

BISCONSINI, D. R. Avaliação da Irregularidade Longitudinal dos Pavimentos com Dados Coletados por Smartphones. Dissertação de mestrado. Escola de Engenharia de São Carlos da Universidade de São Paulo, 2016.

CALLIL, C. A bicicleta na mobilidade urbana como objeto de estudo. In: Estudos de mobilidade por bicicleta. São Paulo: Cebrap, 2018.

CET. Manual de Sinalização Urbana - Espaço Cicloviário - Critérios de Projeto. São Paulo: CET, v. 13, 2014. 
Programa Cicloviário do Município de São Paulo: um investimento em sustentabilidade. [São Paulo]: Notas Técnicas, NT 249, 2016. Disponível em <http://www.cetsp.com.br/media/516079/nt249.pdf>. Acesso em: 15 fev. 2018.

CHOU, C.; LEE, W.; CHEN, A.; WANG, R.; TSENG, I.; LEE, C. Simulation of Bicycle-Riding Smoothness by Bicycle Motion Analysis Model. In: Journal of Transportation Engineering, Reston: ASCE, n. 141, v. 12, 2015.

CICLOCIDADE. Auditoria cidadã da estrutura cicloviária de São Paulo, 2018. Disponível em <https://www.ciclocidade.org.br/biblioteca/pesquisa-ciclocidade/file/ -relatorio-auditoria-cidada>. Acesso em: 05 set. 2019.

CLASON, D. L.; DORMODY, T. J. Analyzing data measured by individual Likert-type items. In: Journal of Agricultural Education, Fayetteville: AAAE, v. 35 n. 4 pp. 31- 35, 1994.

CHAPADEIRO, F. C. Limites e potencialidades do planejamento cicloviário: um estudo sobre a participação cidadã. Dissertação de mestrado. Universidade de Brasilia, 2011.

COMISSÃO EUROPÉIA. Cidades para Bicicletas, Cidades do Futuro. Bélgica, 2000.

CROW. Design Manual for Bicycle Traffic. Ede: CROW, 2007.

DECASTRO, J. Sistemas de bicicletas compartilhadas do Rio de Janeiro (Bike Rio): uma análise exploratória do padrão de viagens e perfil de usuários. In: Estudos de mobilidade por bicicleta. São Paulo: Cebrap, 2018.

DNER. Guia de Gerência de Pavimentos. Rio de Janeiro,1983.

DNIT. Avaliação objetiva da superfície de pavimentos flexíveis e semi-rígidos Procedimento. Rio de Janeiro: DNIT, 2003a. Disponível em <http://ipr.dnit.gov.br/ normas-e-manuais/normas/procedimento-pro/dnit006_2003_pro.pdf>. Acesso em: 15 fev. 2018.

Defeitos nos pavimentos flexíveis e semi-rígidos - Terminologia. Rio de Janeiro: DNIT, 2003b. Disponível em <http://ipr.dnit.gov.br/normas-emanuais/normas/terminologia-ter/dnit005_2003_ter.pdf>. Acesso em 13 abr. 2019. Pavimento rígido - Defeitos - Terminologia. Rio de Janeiro: DNIT, 2004. Disponível em <http://ipr.dnit.gov.br/normas-e-manuais/normas/terminologiater/dnit061_2004_ter.pdf >. Acesso em: 15 fev. 2018. 
DIGIOIA J.; WATKINS, K. E.; XU, Y.; RODGERS, M.; GUENSLER, R. Safety impacts of bicycle infrastructure: A critical review. In: Journal of Safety Research, Amsterdã: Elsevier, v. 61, p. 105-119, 2017.

EMMERT, F.; PEREIRA, R. S.; REZENDE A. V.; ENCINAS, J. M. I. Geoprocessamento como Ferramenta de Apoio à Gerência de Pavimentos em Estradas Florestais. In: Ciência Florestal, Santa Maria: UFSM, v. 20, n. 1, p. 81-94, 2010.

FERREIRA, A. J. L.; VICENTE, F. A. A.; MENESES, S. C. N. Pavementmanagement system for Oliveira do Hospital, Portugal. In: Proceedings Of The ICE Transport, Londres: ICE, v. 162, n. 3, p.157-169, 2009.

FHWA. Distress Identification Manual for the Long-Term Pavement Performance Program. 4 ed. Washington DC: FWHA, 2003. Disponível em $<$ https://www.fhwa.dot.gov/publications/research/infrastructure/pavements/ltpp/report s/03031/03031.pdf>. Acesso em: 15 fev. 2018.

FLANNERY, A.; LEDBETTER L.; ARNOLD, L.; JONES, M. Analysis of Bicycle, Pedestrian, and Auto interaction at multilane Roundabouts in the US. In: IV INTERNATIONAL SYMPOSIYM OH HIGHWAY GEOMETRIC DESIGN. Anais... Valencia: Transportation Research Board, 2010. 1 CD-ROM.

GEIPOT. Manual de Planejamento Cicloviário. 3. ed. Brasília-DF: GEIPOT, 2001.

GÖSSLING, E.; CHOI, A. S. Transport transitions in Copenhagen: Comparing the cost of cars and bicycles. In: Ecological Economics, Amsterdã: Elsevier, v. 113, p. 106-113, 2015.

GUALDA, N. D. F. Impactos da evolução tecnológica dos transportes na sociedade: uma visão sistêmica. In: Estudos Urbanos Coleção Documentos. São Paulo: IEA (USP), v. 8, p. 17-28, 1994.

HAAS R.; HUDSON, W. R. Pavement Management Systems. [S.I]: McGrawHill, 1978.

HEYDARI, S.; MIRANDA-MORENO, L. F.; FU, LIPING. Speed limit reduction in urban areas: A before-after study using Bayesian generalized mixed linear models. In: Accident Analysis and Prevention. Amsterdã: Elsevier, v. 73, p. 252-261, 2014. 
$\mathrm{HU}, \mathrm{W}$; CHICCHINO, J. B. Lowering the speed limit from $30 \mathrm{mph}$ to $25 \mathrm{mph}$ in Boston: effects on vehicle speeds. In: Injury Prevention, Arlington: BMJ, n. 043025, 2018.

HUDSON, S. T.; HUDSON, W. R.; CARMICHAEL III, R. F. Minimum requirements for standard pavement management systems. In: Pavement management implementation. Philadelphia: ASTM, 1991.

HÖLZEL, C.; HÖCHTL, F.; SENNER, V. Cycling comfort on different roads surfaces. In: Procedia Engineering, Amsterdã: Elsevier, v. 34, p. 479-484, 2012.

IDAE. Guía metodológica para la implantación de bicicletas públicas em España. Madri: IDAE, $2007 . \quad$ Disponível em $<$ https://www.idae.es/uploads/documentos/documentos_Guia_Bicicletas_8367007d.p df>. Acesso em: 25 ago. 2018.

IEMA. A bicicleta e as cidades: como inserir a bicicleta na política de mobilidade urbana. São Paulo: IEMA, 2009.

ITDP BRASIL. Morte e vida nas rodovias urbanas. [S.I.]: Instituto de Políticas de Transporte e Desenvolvimento, 2013. . Política de Mobilidade por Bicicletas e Rede Cicloviária da Cidade de São Paulo: Análise e Recomendações. [S.I.]: Instituto de Políticas de Transporte e Desenvolvimento, 2015.

$\mathrm{KOH}$, P. P.; WONG, Y. D. Influence of infrastructural compatibility factors on walking and cycling route choices. In: Journal of Environmental Psychology, Amsterdã: Elsevier, v. 36, p. 202-213, 2013.

LEE, C.; SHIN, H. C., KANG, S.; LEE, J. Measurement of Desireble Minimum One-Way Bike Lane Width. In: KSCE Journal of Civil Engineering, Amsterdã: Springer, v. 20, ed. 2, p. 881-889, 2015.

LI, Y.; LIU, C.; DING, L. Impact of pavement conditions on crash severity. In: Accident Analysis \& Prevention, Amsterdã, v. 59, p. 339-406, 2013.

MADSEN, T. K. O.; LAHRMANN, H. Comparison of five Bicycle Facility designs in signalized intersections using traffic conclict studies. Transportation Research Part F, Amsterdã, v. 46, p. 438-450, 2017.

MASCARENHAS, C. C. Um modelo de geração de viagens de bicicleta para a cidade de São Paulo. In: Estudos de mobilidade por bicicleta. São Paulo: Cebrap, 2018. 
MILAKIS, D., ATHANASOPOULOS, K. What about people in cycle network planning? Applying participative multicriteria GIS analysis in the case of the Athens metropolitan cycle network. In: Journal of Transport Geography. Amsterdã, v. 35, p. 120-129, 2014.

MOORE, I.D., GRAYSON, R.B., LADSON, A.R. Digital Terrain Modelling: A Review of Hydrological, Geomorphological, and Biological Applications. In: Hydrological Processes, Hoboken: Wiley, v. 5, n.1, p. 3-30, 1991.

NCE. Pavement City of Davis - Management Program Update Report. Davis: Project n. 370.12.55, NCE, 2016.

OECD. Road maintenance management systems in developing countries. Paris: OECD, 1995.

PARIDA, M.; AGGARWAL, S.; JAIN S.S. Enhancing pavement management systems using GIS. In: Proceedings Of The ICE - Transport, Londres, v. 158, n. 2, p.107-113, 2005.

ROSIN, L. B. Construção e execução da agenda de políticas cicloviárias em Bogotá, Buenos Aires e São Paulo. In: Estudos de mobilidade por bicicleta. São Paulo: Cebrap, 2018.

SAYERS, M. W.; KARAMIHAS, S. M. The little book of profiling. Ann Arbor: Transportation Research Institute, University of Michigan, 1998. Disponível em: <http://www.umtri.umich.edu/content/LittleBook98R>. Acesso em: 17 ago. 2019.

SHERESCK, B.; LERNER, M. Cyclist Safety: An Overview of Germany's Design Guidelines, Research and Accident Statistics. In: V INTERNATIONAL SYMPOSIUM ON HIGHWAY GEOMETRIC DESIGN. Anais... Vancouver: Transportation Research Board, 2015. 1 CD-ROM.

SOLMINIHAC-TAMPIER, H. Gestión de infraestructura vial. Santiago: Ediciones ARQ, 2001.

TORRES-FREIRE, C.; CALLIL, V.; CASTELLO, G. O impacto do uso da bicicleta em São Paulo. São Paulo: Cebrap, 2018.

TRANSPORT CANADA. Bicycle end-of-trip facilities, a guide for Canadian municipalities and employers. Ottawa: Transport Canada, 2010. Disponível em <http://publications.gc.ca/collections/collection_2011/tc/T22-194-2010-eng.pdf>. Acesso em: 26 ago. 2018.

VASCONCELLOS, E. A. Políticas de transporte no brasil: a construção da mobilidade excludente. Barueri: Manole, 2014. 
VERA-VILLARROEL, P.; CONTRERAS, D.; LILLO, S.; BEYLE, C.; SEGOVIA, A.; ROJO, N.; MORENO, S.; OYARZO, F. Perception of safety and liking associates do the colour intervention of bike lanes: contribution from the behavioral sciences to urban design and wellbeing. In: PLOS ONE, São Francisco, v. 11, n. 8, 2016.

ZHOU, G.; WANG, L.; WANG D.; REICHLE, S. Integration of GIS and Data Mining Technology to Enhance the Pavement Management Decision Making. In: Journal of Transportation Engineering, Reston, v. 146, n. 4, p. 332-341, 2010. 


\section{APÊNDICE A}

Fac-símile do questionário de percepção comparada.

\section{Avaliação de defeitos de pavimentos de vias cicláveis}

Este é um formulário que irá contribuir para um trabalho de dissertação de mestrado, desenvolvido na Escola Politécnica da Universidade de São Paulo. Um dos objetivos deste trabalho é o de mensurar o conforto e a segurança dos ciclistas na cidade de São Paulo. Se você se considera um ciclista e gostaria de contribuir, a seguir existem algumas perguntas que vão nos ajudar a atingir estes e outros objetivos. 0 tempo aproximado de resposta é de 5 minutos. 


\section{Avaliação de defeitos de pavimentos de vias cicláveis}

"Obrigatónio

\section{Sobre você}

Quantos anos você tem? *

Sua resposta

Qual a sua profissão? *

Sua resposta

Qual seu gênero?*

Feminino

Masculino

Prefiro não responder

Outro:

Há quanto tempo você usa a bicicleta para se deslocar na cidade? *

Eu ainda não uso a bicicleta para me deslocar na cidade

A menos de 6 meses

Entre 6 meses e 1 ano

De 1 a 3 anos

Mais de 3 anos

$$
\text { VOLTAR PRÓXIMA }
$$




\section{Avaliação de defeitos de pavimentos de vias cicláveis}

*Obrigatónio

\section{Sobre sua rotina com a bicicleta}

Por qual principal motivo você usa a bicicleta para se deslocar na cidade? *

A bicicleta é meu principal instrumento de trabalho (ex. Bike entregas, Bike couriers etc.)

Trabalho

Educação / Escola

Compras / Serviços

Médico / Dentista / Saúde

Recreação / Lazer

Todos motivos acima

Qual a frequência que você usa a bicicleta para se deslocar para suas principais atividades no dia (ir à escola, ao trabalho, lazer etc.)? *

Apenas aos fins de semana

De 1 a 2 vezes na semana

De 3 a 4 vezes na semana

5 ou mais vezes na semana

VOLTAR PRÓXIMA

Página 3 de 5 


\section{Avaliação de defeitos de pavimentos de vias cicláveis}

sobrigatório

\section{Sobre seu conforto e segurança}

Com base na sua experiência na cidade de São Paulo, avalie o quanto os seguintes problemas e defeitos influenciam o seu conforto e segurança em vias cicláveis. As notas variam de 1 (problema pouco ou nada importante) a 5 (problema ou defeito muito grave). Se tiver dúvidas ou mudar de opinião, você poderá mudar suas notas livremente até finalizar todo o formulário.

\section{A - Fissuras isoladas *}
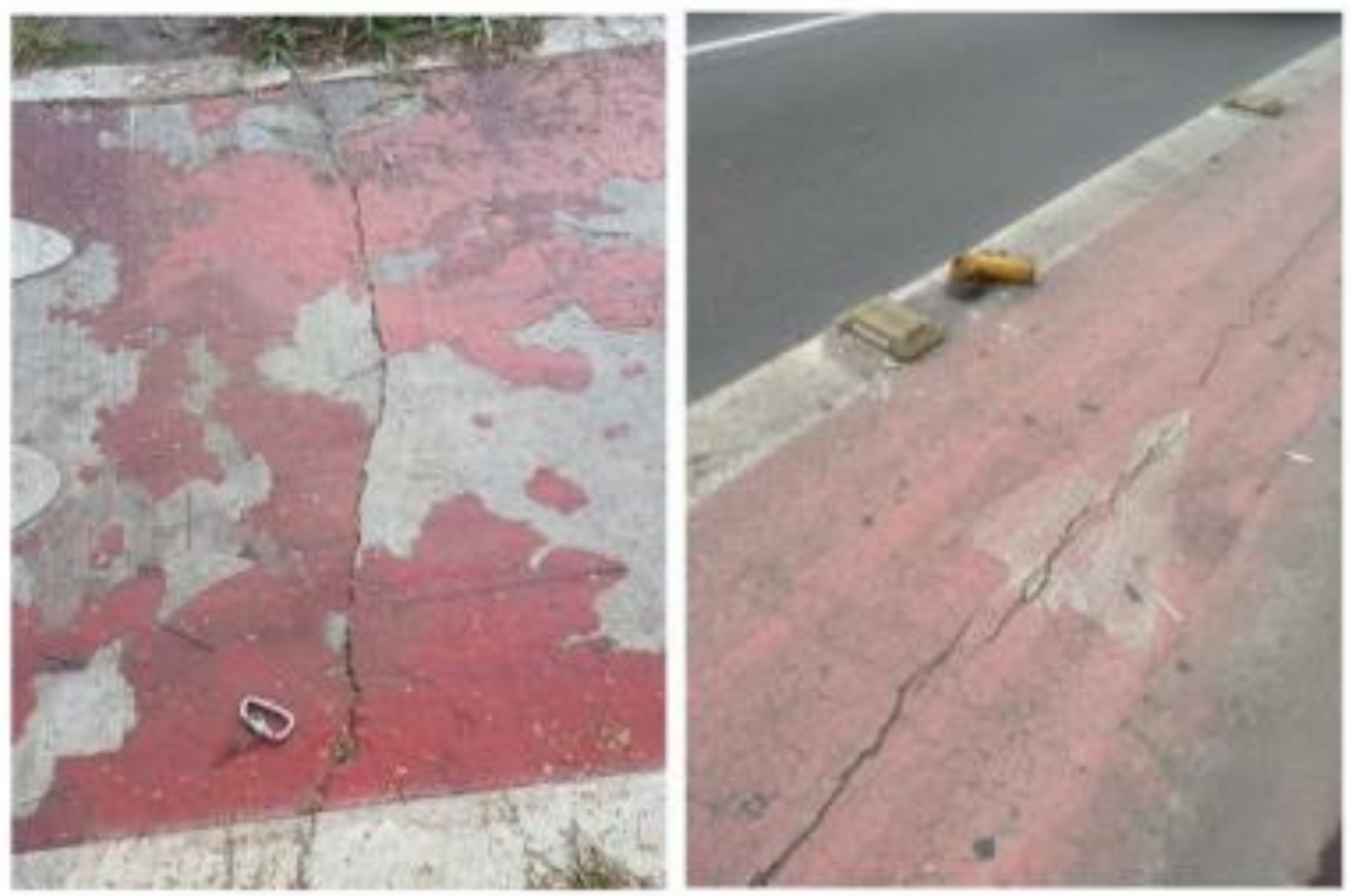

$\begin{array}{lllll}1 & 2 & 3 & 4 & 5\end{array}$

Defeito pouco ou nada grave

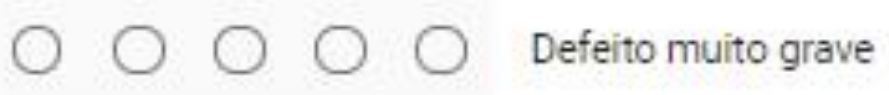


B - Fissuras em blocos *
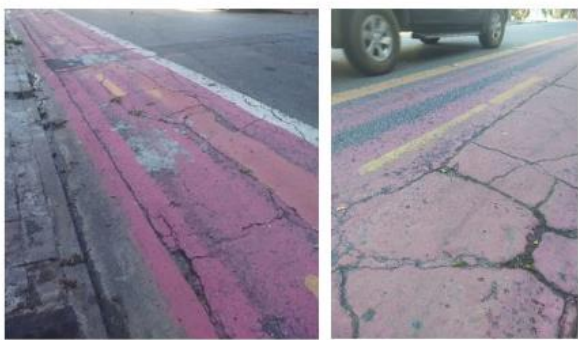

$\begin{array}{lllll}1 & 2 & 3 & 4 & 5\end{array}$

Defeito pouco ou nada

C - Quebras *
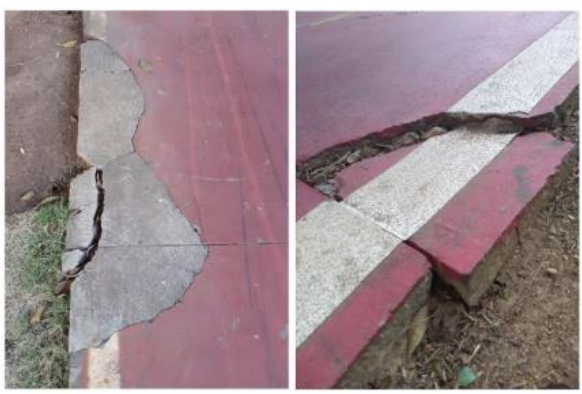

$\begin{array}{lllll}1 & 2 & 3 & 4 & 5\end{array}$

Defeito pouco ou nada grave

00000 Defeito muito grave

F - Degrau ou escalonamento de juntas *

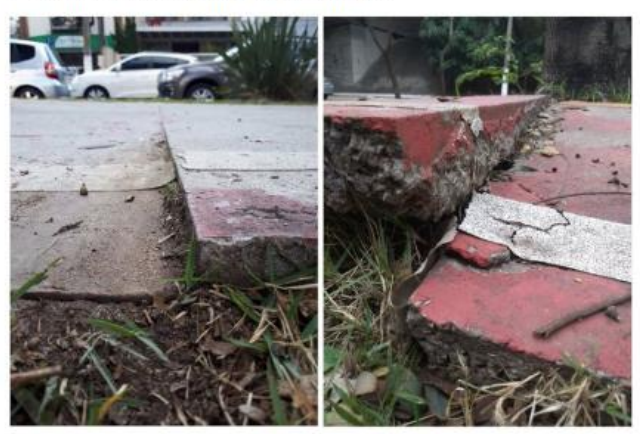
grave

$000 \bigcirc \bigcirc$ Defeito muito grave

G - Abertura de juntas *
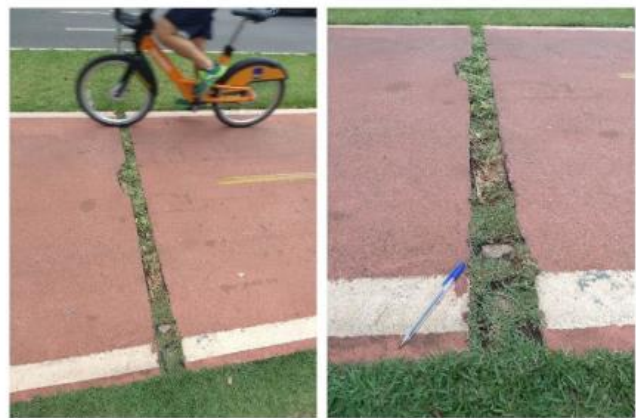

$\begin{array}{lllll}1 & 2 & 3 & 4 & 5\end{array}$

Defeito pouco ou nada grave
D- Buracos *

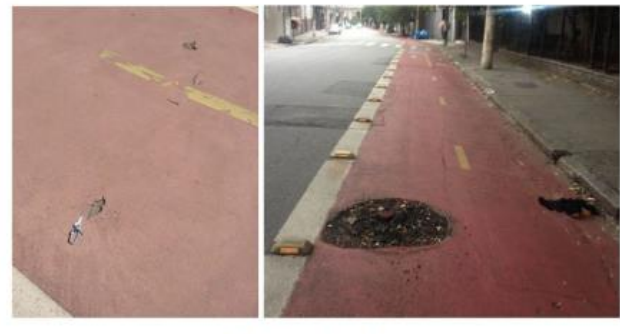

$\begin{array}{lllll}1 & 2 & 3 & 4 & 5\end{array}$

Defeito pouco ou nada $\bigcirc \bigcirc \bigcirc \bigcirc \bigcirc$ Defeito muito grave

E-Esborcinamento (desgaste) de juntas *

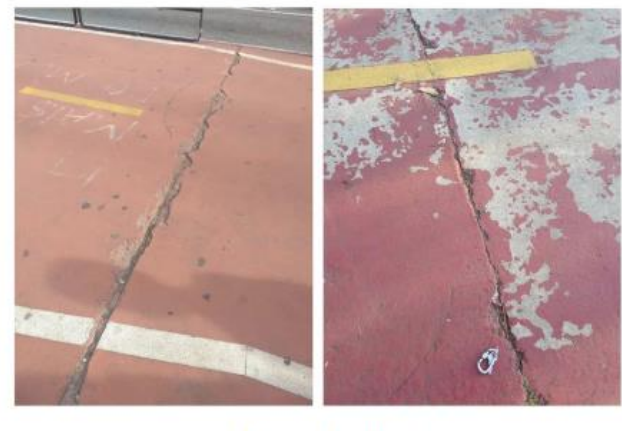

Defeito pouco ou nada $\bigcirc \bigcirc \bigcirc \bigcirc \bigcirc$ Defeito muito grave

$\mathrm{H}$ - Alçamento de placas *

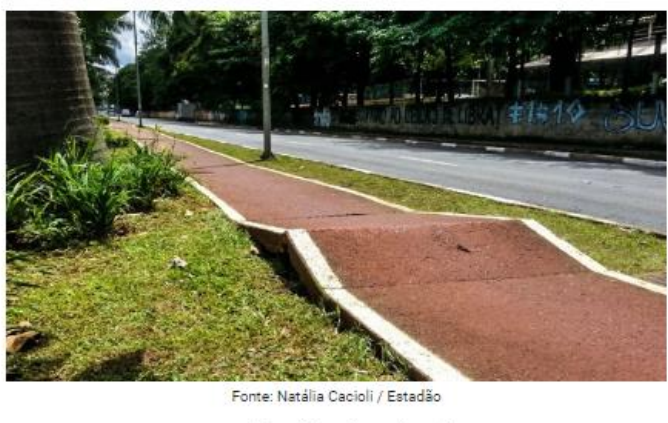

$\begin{array}{lllll}1 & 2 & 3 & 4 & 5\end{array}$

$\underset{\text { Defeito pouco ou nada }}{\text { grave }} \mathrm{O} \bigcirc \mathrm{O}$ Defeito muito grave

I - Desgaste da cor do pavimento *

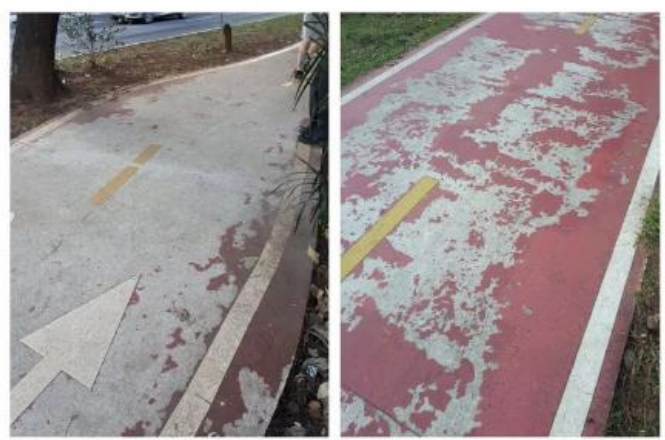

Defeito pouco ou nada
00000 Defeito muito grave 
J-Remendos *
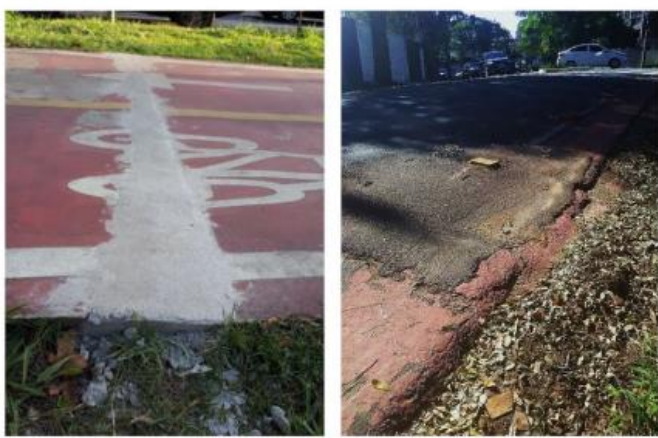

$\begin{array}{llll}2 & 3 & 4 & 5\end{array}$

Defeito pouco ou nada grave

L - Afundamento (depressões ou ondulações) *

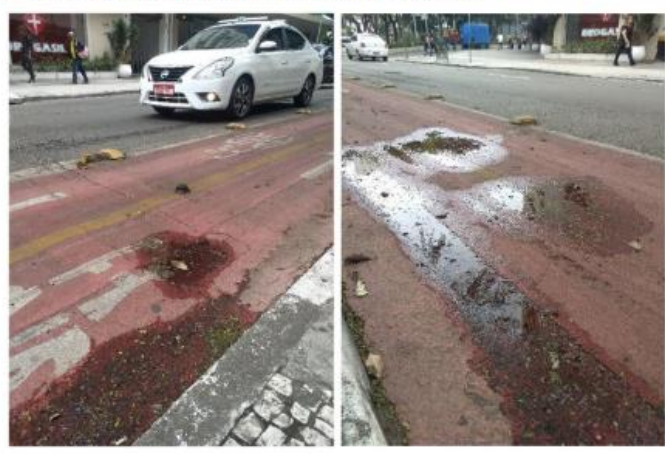

$\begin{array}{lllll}1 & 2 & 3 & 4 & 5\end{array}$

Defeito pouco ou nada grave

00000 Defeito muito grave
M - Escorregamento *

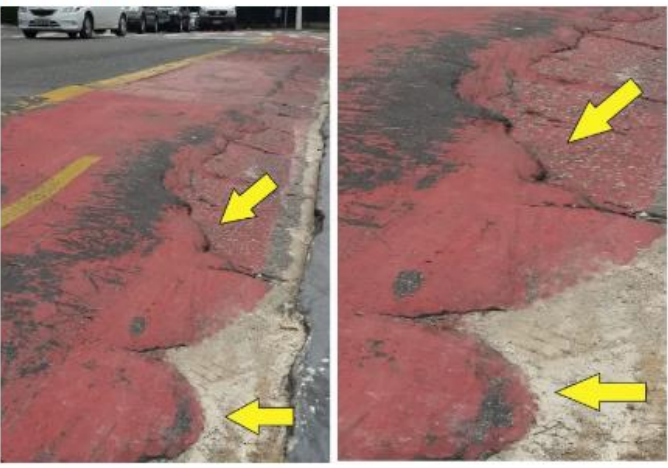

$\begin{array}{lllll}1 & 2 & 3 & 4 & 5\end{array}$

Defeito pouco ou nada $\bigcirc \bigcirc \bigcirc \bigcirc \bigcirc$ Defeito muito grave

$\mathrm{N}$ - Juntas de transição *

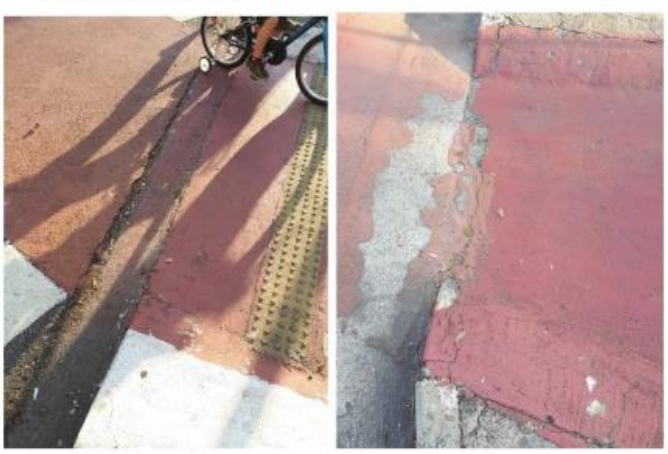

$\begin{array}{llll}1 & 2 & 3 & 4\end{array}$

Defeito pouco ou nada 00000 Defeito muito grave

P - Desnível entre via ciclável e sarjeta *

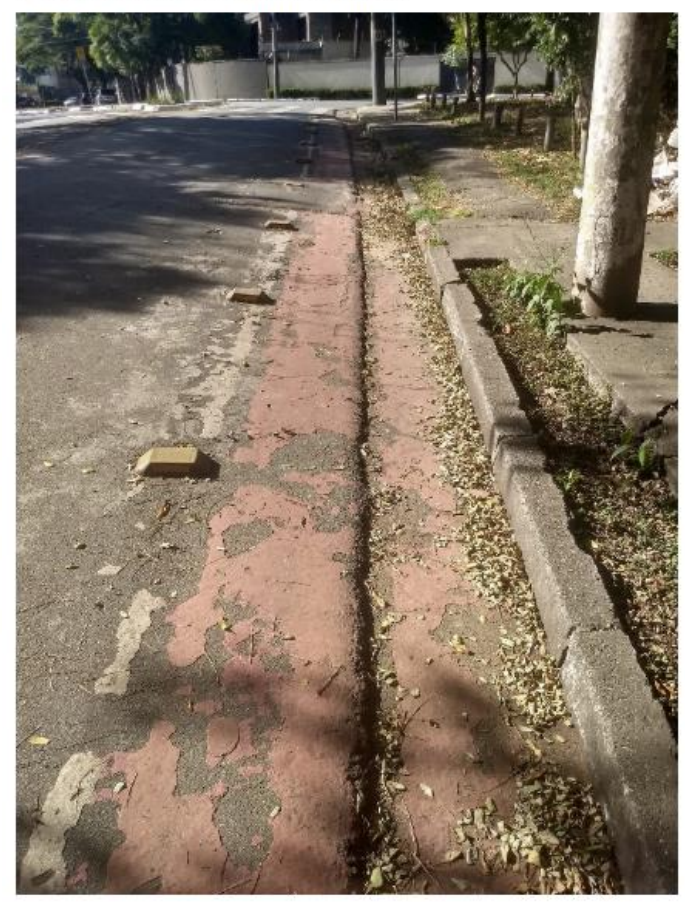

$\begin{array}{lllll}1 & 2 & 3 & 4 & 5\end{array}$ $\underset{\substack{\text { Defeito pouco ou nada } \\ \text { grave }}}{\mathrm{O}} \mathrm{O} \bigcirc \mathrm{\text {Defeitomuitograve }}$

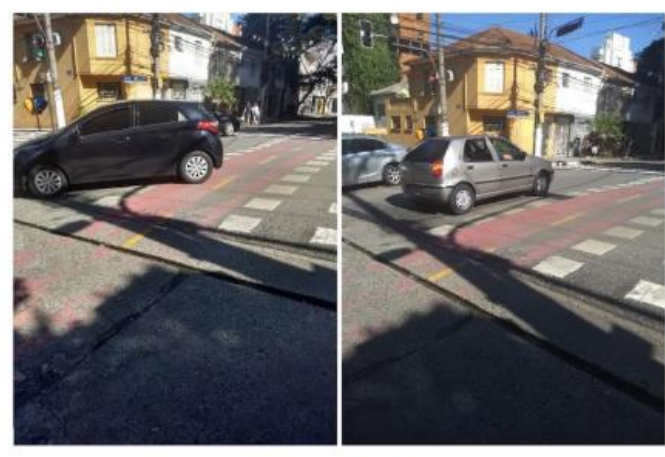

Defeito pouco ou nade grave
$0000 \bigcirc$ Defeito muito grave 
Q - Sarjeta como parte da via ciclável *
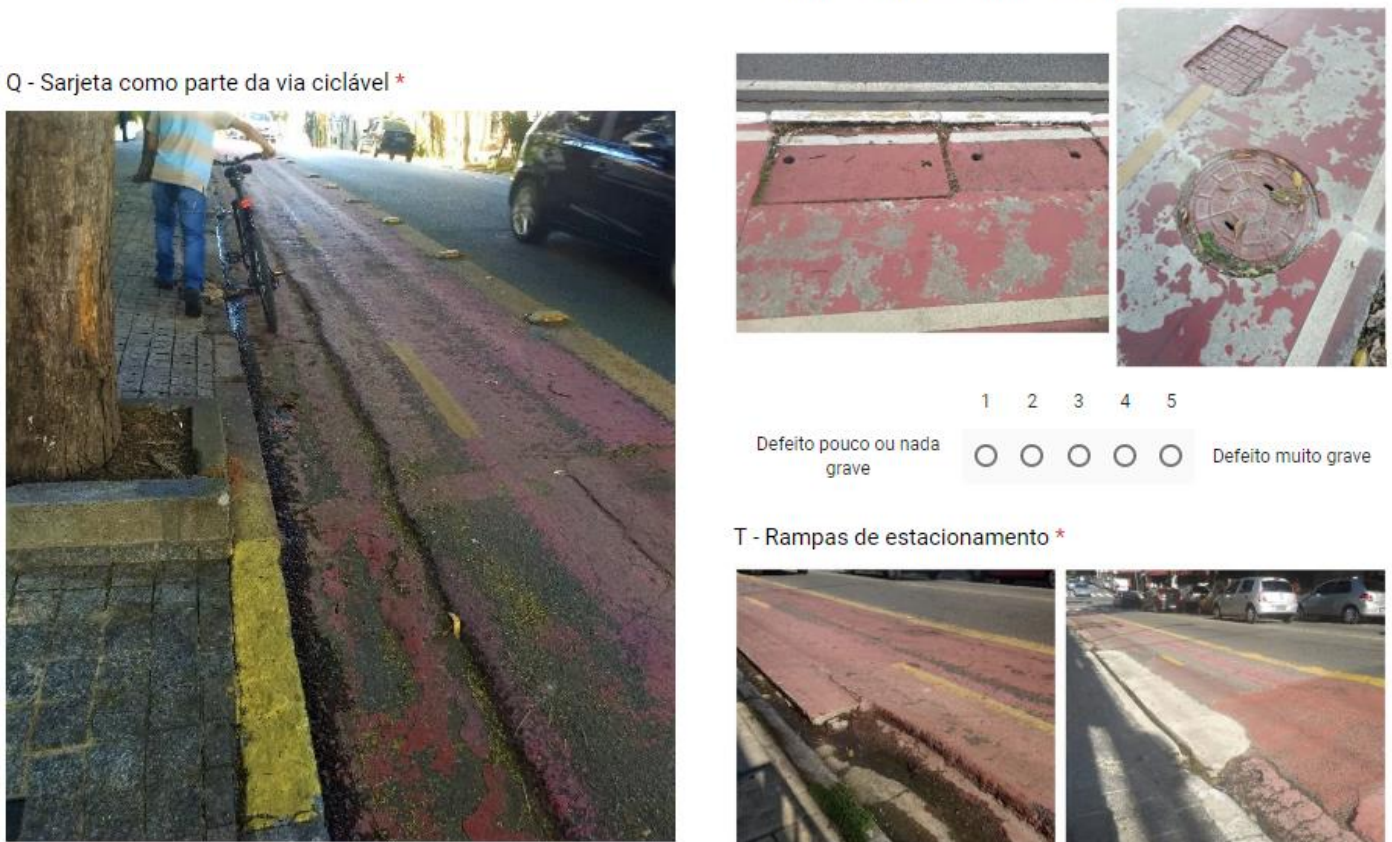

$\begin{array}{lllll}1 & 2 & 3 & 4 & 5\end{array}$

Defeito pouco ou nada
grave $\mathrm{O} \bigcirc \mathrm{O}$ Defeito muito grave

T - Rampas de estacionamento *

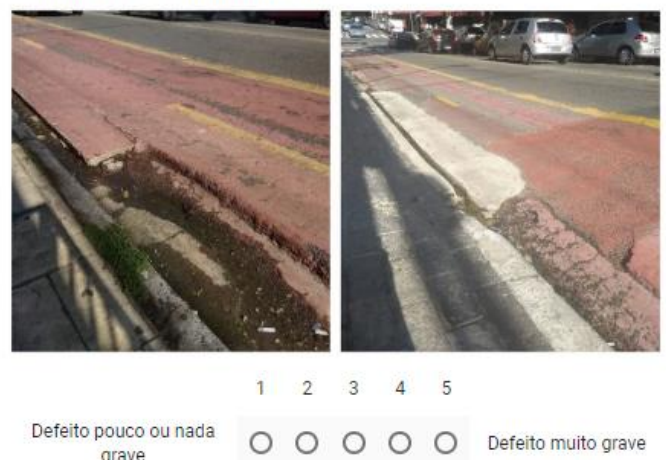

$$
\text { grave }
$$

$\bigcirc \bigcirc \bigcirc \bigcirc \bigcirc$ Defeito muito grave

R - Grelha de sarjeta com espaço longitudinal acentuado *

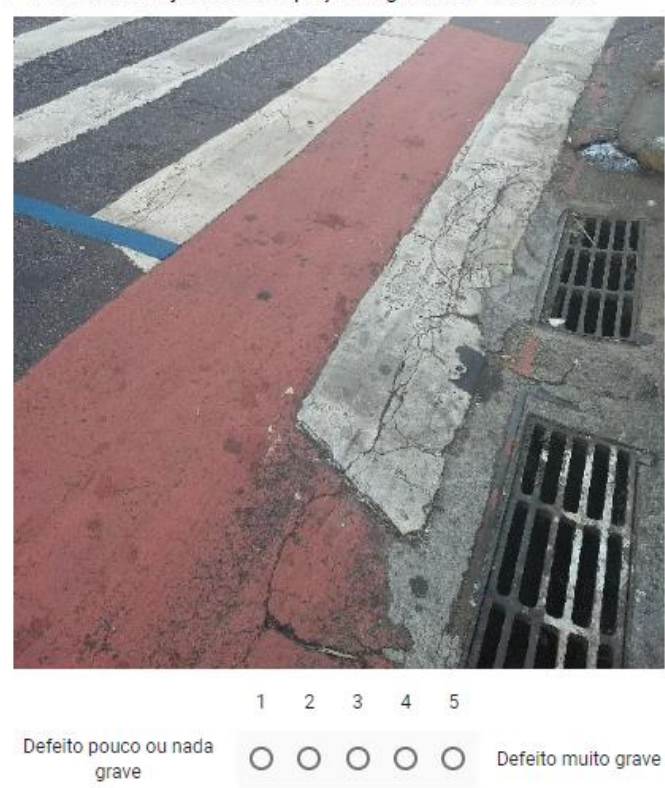

Avaliação de defeitos de pavimentos de vias cicláveis

\section{Muito obrigado!}

Caso queira saber mais ou contribuir com idéias e sugestões, deixe aqui o seu nome, e-mail ou comentários.

Sua resposta 


\section{APÊNDICE B}

Histogramas de frequências de respostas ao questionário de percepção comparada por tipo de defeito.
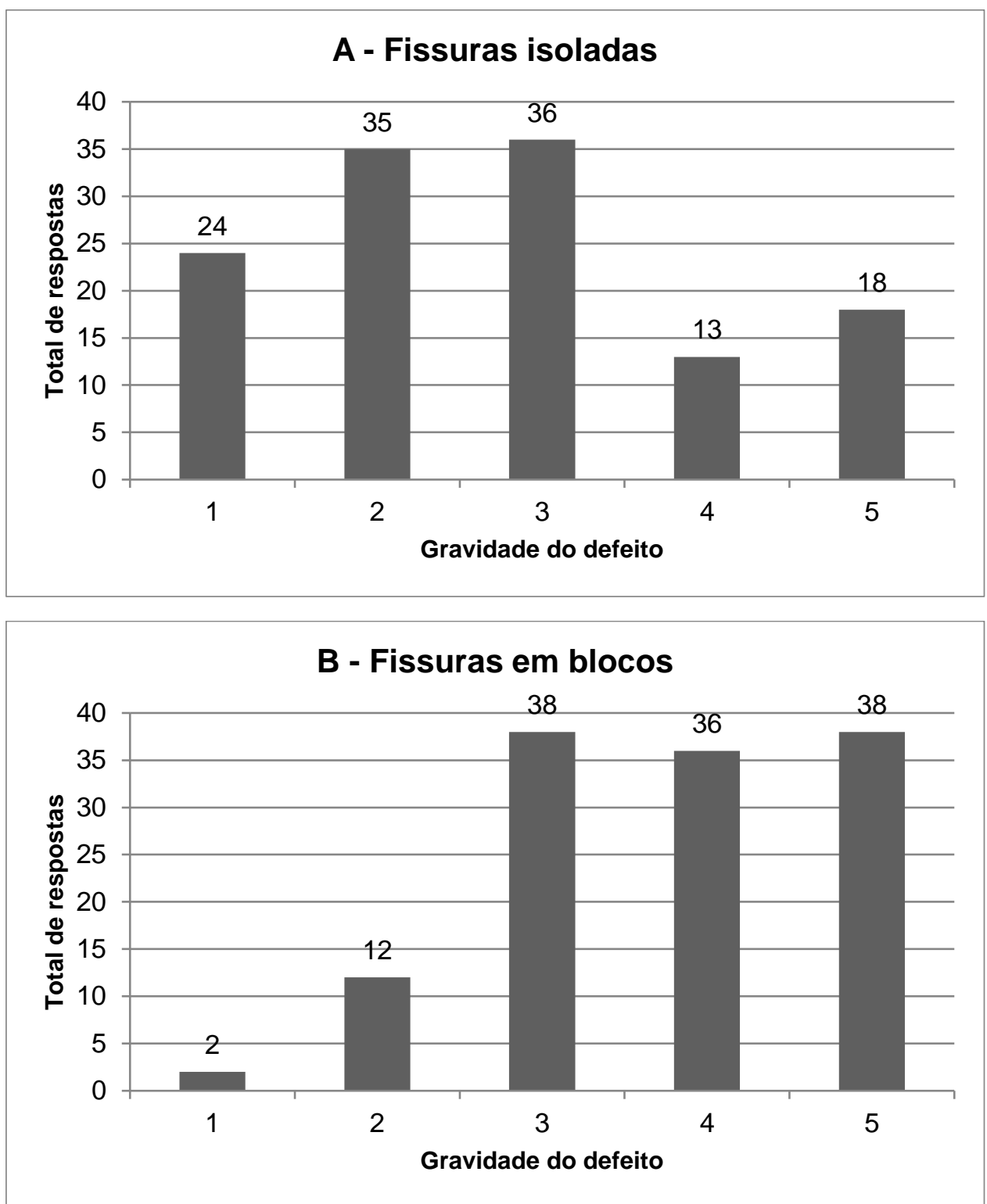

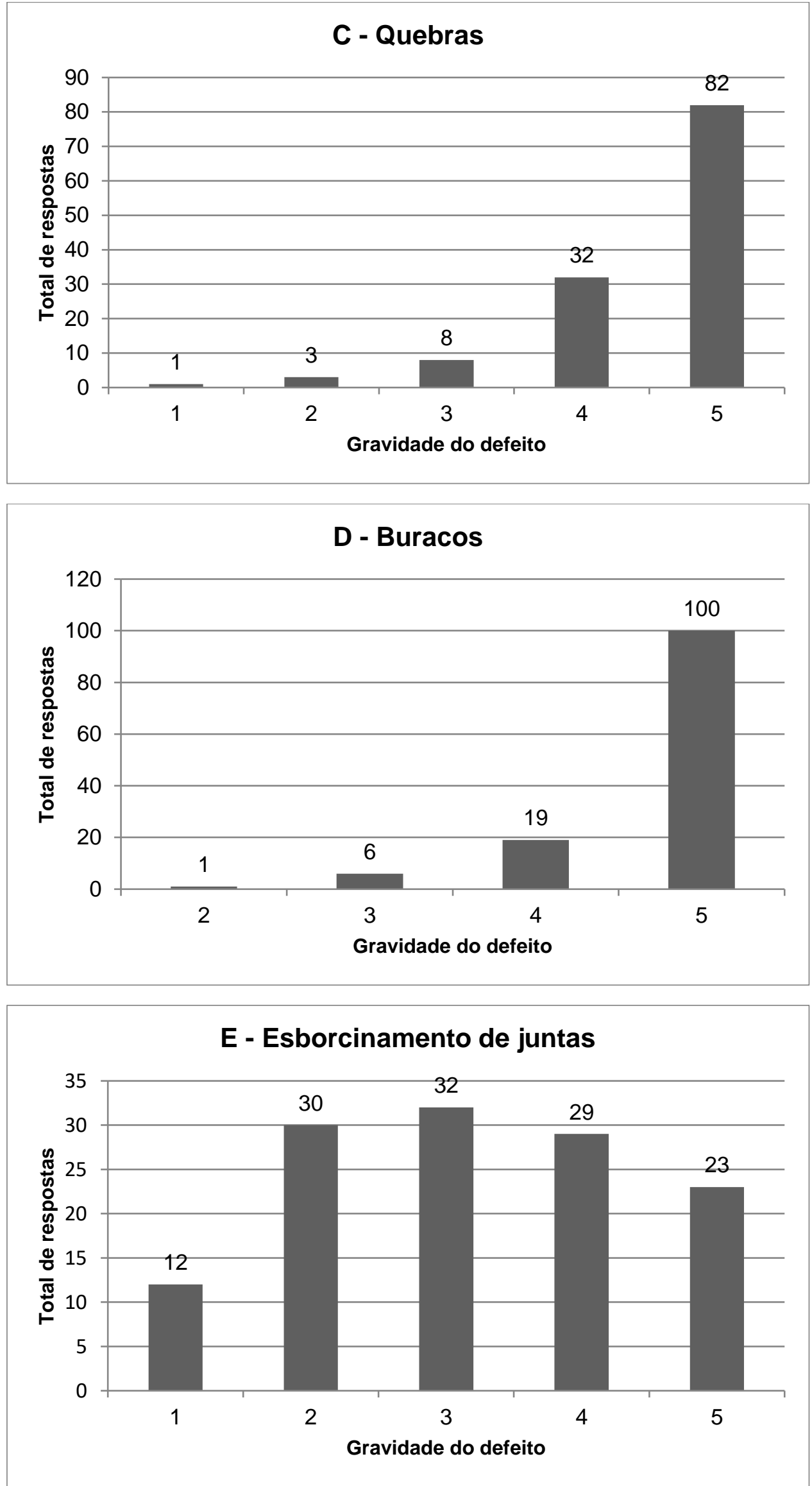

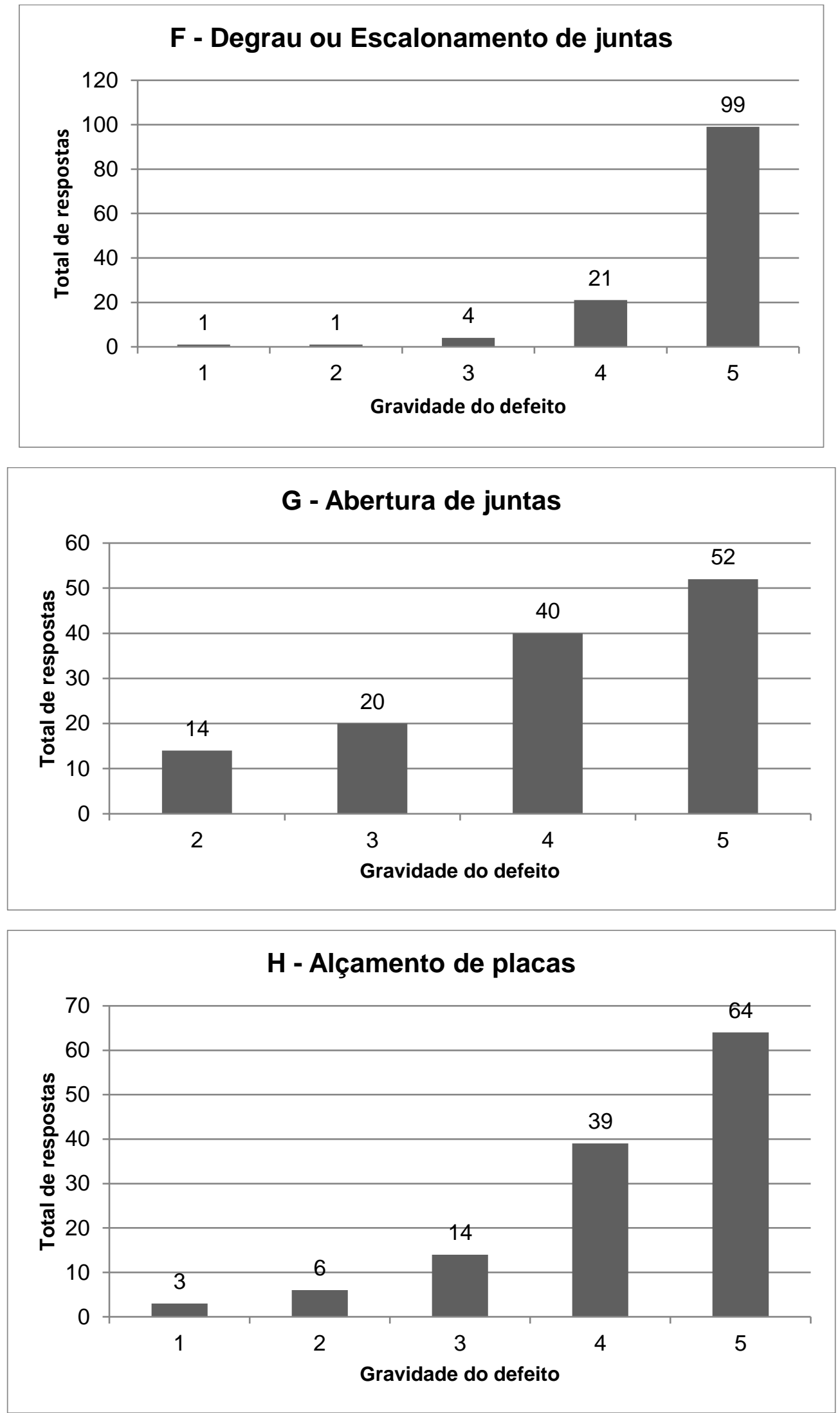

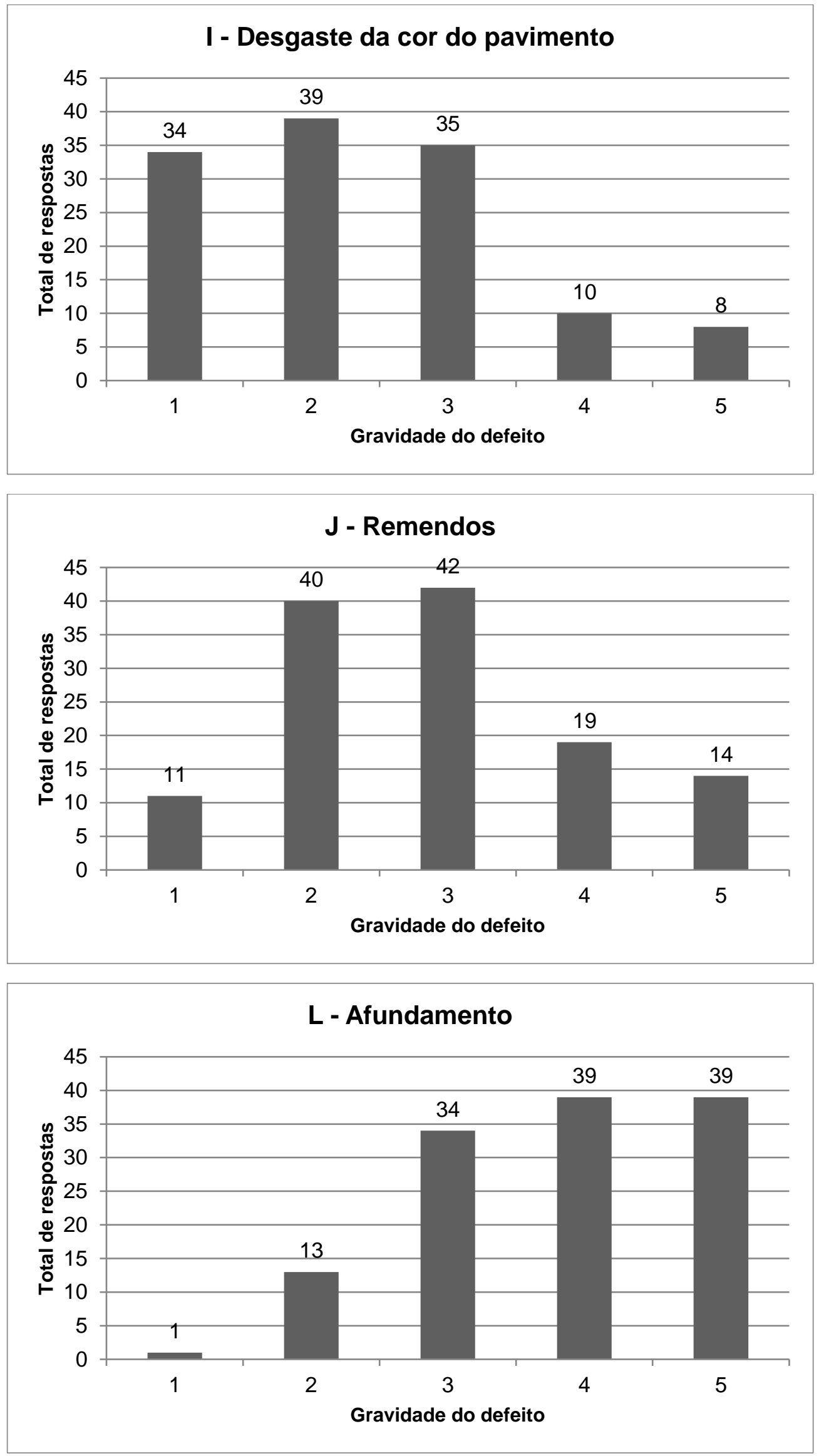

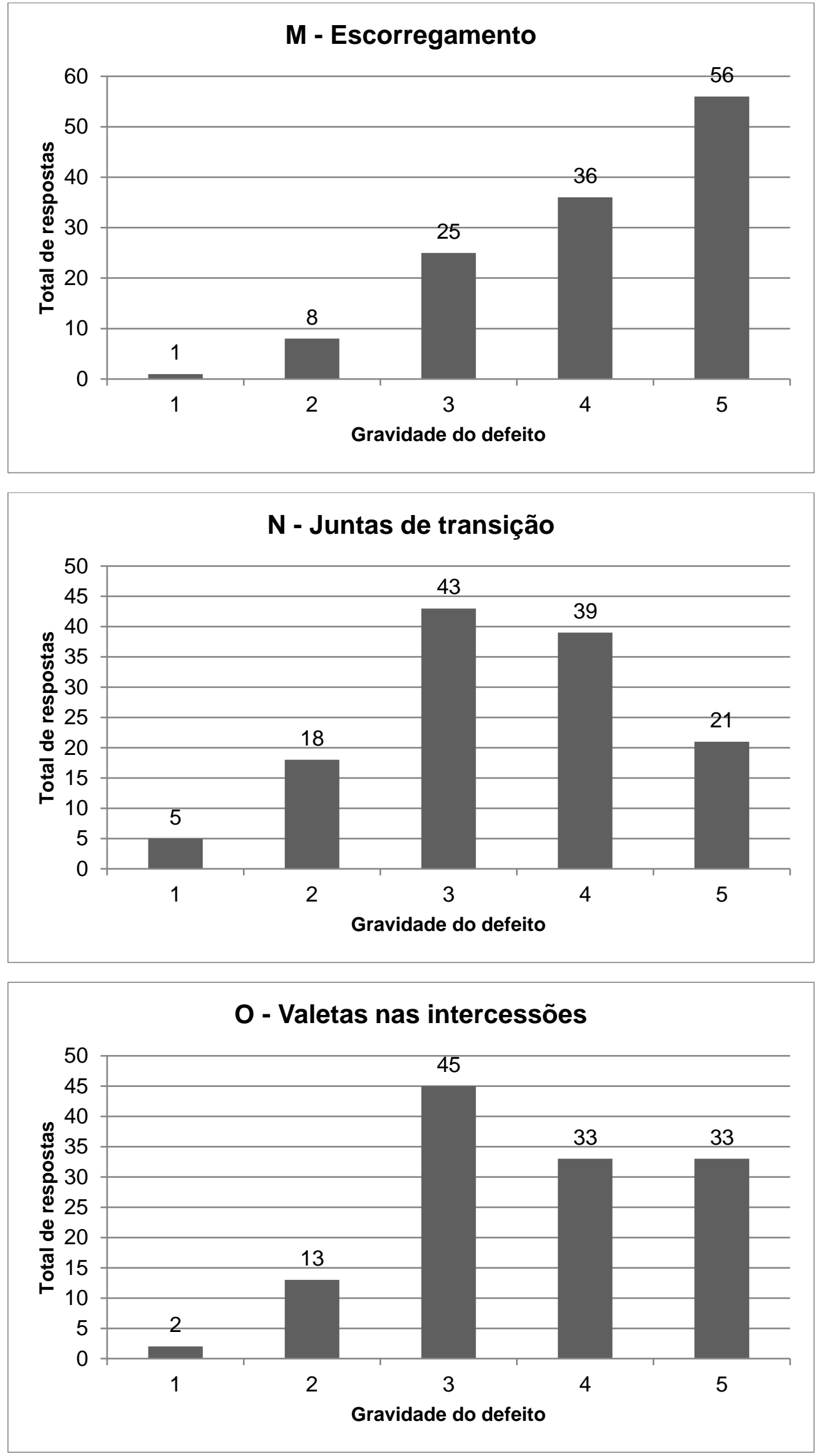

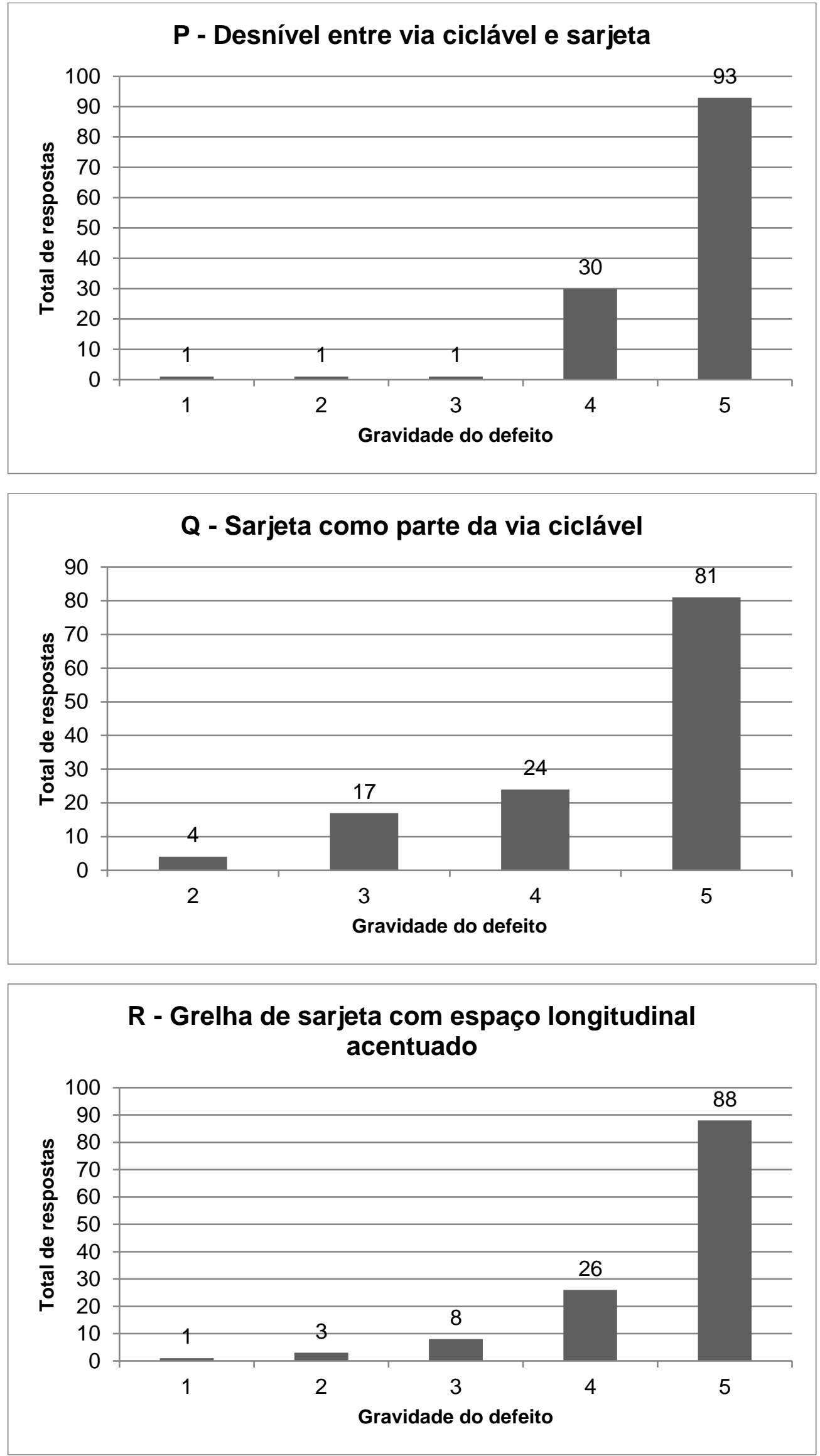

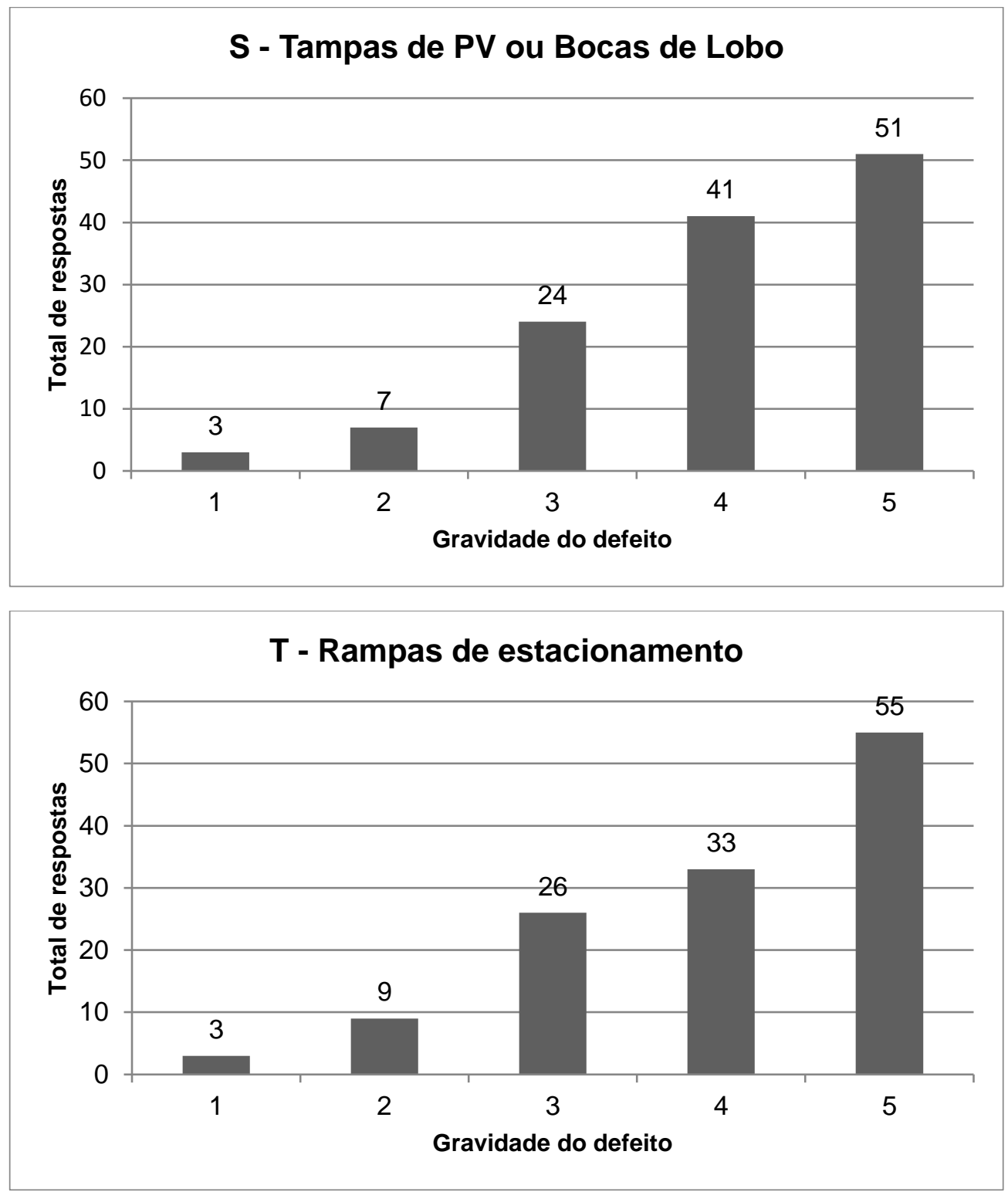